\title{
Tussen wet en werkelijkheid; euthanasie in het licht van de roman van Willem Jan Otten en de filosofie van Maurice Merleau-Ponty
}

Citation for published version (APA):

Soeting, M. F. (2005). Tussen wet en werkelijkheid; euthanasie in het licht van de roman van Willem Jan Otten en de filosofie van Maurice Merleau-Ponty. [Doctoral Thesis, Maastricht University]. https://doi.org/10.26481/dis.20050428ms

Document status and date:

Published: 01/01/2005

DOI:

10.26481/dis.20050428ms

Document Version:

Publisher's PDF, also known as Version of record

Please check the document version of this publication:

- A submitted manuscript is the version of the article upon submission and before peer-review. There can be important differences between the submitted version and the official published version of record.

People interested in the research are advised to contact the author for the final version of the publication, or visit the DOI to the publisher's website.

- The final author version and the galley proof are versions of the publication after peer review.

- The final published version features the final layout of the paper including the volume, issue and page numbers.

Link to publication

\footnotetext{
General rights rights.

- You may freely distribute the URL identifying the publication in the public portal. please follow below link for the End User Agreement:

www.umlib.nl/taverne-license

Take down policy

If you believe that this document breaches copyright please contact us at:

repository@maastrichtuniversity.nl

providing details and we will investigate your claim.
}

Copyright and moral rights for the publications made accessible in the public portal are retained by the authors and/or other copyright owners and it is a condition of accessing publications that users recognise and abide by the legal requirements associated with these

- Users may download and print one copy of any publication from the public portal for the purpose of private study or research.

- You may not further distribute the material or use it for any profit-making activity or commercial gain

If the publication is distributed under the terms of Article $25 \mathrm{fa}$ of the Dutch Copyright Act, indicated by the "Taverne" license above, 


\section{TUSSEN WET EN WERKELIJKHEID}

Euthanasie in het licht van een roman van

Willem Jan Otten en de filosofie van

Maurice Merleau-Ponty 
(C) Monica Soeting, 2005

Omslagontwerp: Zeno

Ontwerp binnenwerk: Zeno

Zetwerk: Cilia van Weerdenburg

IS BN $905278454 \mathrm{X}$ 


\section{TUSSEN WET EN WERKELIJKHEID}

Euthanasie in het licht van een roman van

Willem Jan Otten en de filosofie van

Maurice Merleau-Ponty

\section{PROEFSCHRIFT}

Ter verkrijging van de graad van doctor

aan de Universiteit Maastricht, op gezag van de Rector Magnificus,

Prof. Mr. G.P.M.F. Mols

volgens het besluit van het College van Decanen, in het openbaar te verdedigen op donderdag 28 april 2005 om 14.00 uur

door

Monica Francisca Soeting

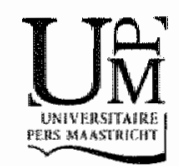




\section{Promotores:}

Prof. Dr. G.A.M. Widdershoven

Prof. Dr. J.H.W. Kusters

Beoordelingscommissie:

Prof. Dr. R. Vos (voorzitter)

Dr. R.P.L. Berghmans

Dr. R. Hendriks

Prof. Dr. H.J. Pott

Prof. Dr. D.L. Willems (Universiteit van Amsterdam) 


\section{Inhoud}

I Inleiding

I Dood op verzoek

2 Tussen wet en werkelijkheid

3 Opzet

II De kritiek op de legalisering van euthanasie en hulp bij zelfdoding in essays van Willem Jan Otten

I Inleiding

2 Een vrijwillig en weloverwogen verzoek

3 Uitzichtloos en ondraaglijk lijden

4 Overleg en consultatie

5 Schriftelijke wilsverklaringen

6 Samenvatting en conclusie

III Ons mankeert niets als tragedie

I Inleiding

2 Ons mankeert niets

3 'Aldus hadden beschikt'

4 De onmeetbaarheid van het lijden

5 Kennis maakt medeplichtig

6 De toekomst laat zich niet bepalen

7 Samenvatting en conclusie

IV Ons mankeert niets als historie

I Inleiding

2 Vrijheid door begrip

3 De tweede klacht

4 Het gesprek

5 Het belang van toekomstplannen

6 Samenvatting en conclusie 
$\checkmark$ De filosofie van Maurice Merleau-Ponty $\quad 119$

1 Inleiding 119

2 De natuurlijke vergissing 122

3 Motivatie komt na de beslissing 131

4 Echt en onecht lijden $\mathbb{1 3 9}$

$5 \quad \mathrm{Zijn}$ is zijn met de ander $\quad 142$

6 Dedoodals zingeving $\quad 152$

7 Ten slotte $15^{8}$

VI Slotbeschouwing 161

1 Inleiding 161

2 De verhouding tussen wet en werkelijkheid 164

3 Wat doe je als je weet dat iemand dood wil? $\quad 166$

Noten 171

Geraadpleegde literaturur $\quad{ }_{1.83}$

Bijlage: Wet toetsing levensbeëindiging op verzoek

en hulp bij zelfdoding

191

Summary (samenvatting in het Engels) 201

Dankwoord 206

Curriculum Vitae 208 


\section{Inleiding}

Op 13 november 1994 verscheen in The New York Times een artikel met de kop 'Helping a Man Kill Himself, As Shown on Dutch TV'. De anonieme auteur reageerde op de Nederlandse IKON-documentaire 'Dood op verzoek', waarin getoond wordt hoe de Amsterdamse huisarts Wilfred van Oijen een einde maakte aan het leven van zijn patiënt Cees van Wendel de Joode. ${ }^{1}$ Van Wendel de Joode leed aan een ernstige spierziekte en was ongeneeslijk ziek verklaard. Hijzelf had te kennen gegeven dat hij een 'zachte dood" wilde sterven. Als men de natuur haar beloop zou laten, hadden de artsen hem verteld, zou hij onder ondraaglijk veel pijnen en angsten doodgaan. Deze documentaire, schreef de auteur van "Helping a Man Kill Himself", was het bewijs dat Nederland zich in de voorhoede van mercy killing bevond. De term 'mercy killing' heeft in dit artikel een pejoratieve klank.

In Groot-Brittannië zond de B BC 'Dood op verzoek' op 15 maart 1995 uit. Op de dag van de uitzending ondertekenden honderdacht afgevaardigden in het Lagerhuis een motie, waarin zij stelden dat de B BC duidelijk moest maken dat in Nederland vaker euthanasie toegepast werd dan in andere landen, omdat de Nederlandse specialistische zorg veel minder ontwikkeld was dan die in Engeland. ${ }^{2}$ Na de uitzending schreef een aantal prominente Britten, onder wie leden van de House of Lords Select Committee on Medical Ethics, een open brief aan The Times waarin zij het Nederlandse euthanasiebeleid bekritiseerden. Volgens de briefschrijvers bevonden de Nederlanders zich, vanaf het moment waarop zij zich met euthanasie hadden ingelaten, op een 'hellend vlak'. Het was te verwachten dat euthanasie binnen afzienbare tijd niet alleen toegepast zou worden op patiënten die daarom vroegen, maar ook op hen die er niet om hadden verzocht. De ontwikkeling in Nederland maakte overduidelijk waarom euthanasie in Groot-Brittannië niet gelegaliseerd moest worden. ${ }^{3}$ In Italië programmeerde een televisieomroep de docu- 
mentaire drie keer, en twee keer verhinderden de regeringspartijen de uitzending. ${ }^{4}$ Ook in Duitsland leidde en leidt het Nederlandse beleid aangaande euthanasie tot protesten. Na verschijning, in 2003 , van de resultaten van het onderzoek naar sterfgevallen in Nederland in het jaar 2001 door P.J. van der Maas en Gerrit van der Wal, constateerden twee Duitse artsen in de Süddeutsche Zeitung van 17 juli 2003 in een artikel met de somber klinkende ondertitel 'Die finstere Praxis der Sterbehilfe in Holland - bis hin zum Mord", dat de Nederlandse wet op euthanasie en hulp bij zelfdoding niet geleid had tot afname van het aantal euthanasiegevallen, maar tot toename daarvan. Zelfs het aantal gevallen van niet-legale euthanasie, de facto dus van moord, zou gestegen zijn sinds de invoering van de wet. In Nederland, stelden de beide auteurs vast, wordt euthanasie tegenwoordig nauwelijks nog toegepast om ongeneeslijk zieken te verlossen van hun lijden, maar veel meer on de omgeving te ontlasten van zieken. Op die manier zou in Nederland de "Freiheit zum Tode' intussen tot 'Unfreiheit zum Leben' geperverteerd zijn. (Eisenmenger en Oduncu 2003) ) $^{5}$ doemscenario zoals een antal vooraanstaande Engelsen dat in 1995 geschetst had, is volgens deze Duitse artsen werkelijkheid geworden.

Hoewel opiniepeilingen laten zien dat de meeste Nederlanders voor legalisering van euthanasie en hulp bij zelfdoding zijn, wordt ook in ons land kritiek geleverd op het Nederlandse euthanasiebeleid. ${ }^{6}$ Sinds de jaren zeventig van de vorige eeuw verschenen honderden wetenschappelijke werken, zelfbekentenissen, essays, boeken, pamfletten en kranten-en tijdschriftartikelen waarin de verschillende auteurs het beleid analyseren, toelichten, verdedigen, maar ook hekelen. In 1995, een jaar na de eerste uitzending van Dood op verzoek, verscheen Als de dood voor het leven, een bundel essays waarin vijf auteurs op verschillende manieren thun aversie tegen de legalisering van euthanasie en professionele hulp bij zelfdoding verwoorden. Hans Achterhuis, Johan Goud, Frank Koerselman, Willem Jan Otten en Tom Schalken reageerden in Als de dood voor het leven in eerste instantie op de bepaling van de Hoge Raad uit 1994 in de zaak van de Haarlemse psychiater B. Chabot, die een nietlichamelijk zieke vrouw geholpen had zichzelf te doden. Chabot werd na vrijspraak door de rechtbank van Assen in 1993 en het gerechtshof Leeuwarden in 1994 weliswaar schuldig en strafbaar verklaard door de Hoge Raad, maar kreeg geen straf of andere maatregel opgelegd. ${ }^{7} \mathrm{De}$ auteurs van Als de dood voor het leven ageerden tegen, zoals zij het uitdrukten, een ontwikkeling die de Nederlanders weer een stap verder bracht in 'de richting van het algemene, en lang verhoopte recht op zelfbeschikking, een ontwikkeling waarbij zij op zijn minst kanttekeningen plaatsten. (Achterhuis e.a. 1995:8) De discussie over de legalisering van eutha- 
nasie was in hun ogen te ver gegaan en zou in politiek opzicht leiden tot een onacceptabel gevolg, namelijk de legalisering van euthanasie inclusief hulp bij zelfdoding. Met de bepaling van de Hoge Raad was een grens overschreden. De 'vooruitgang' schreven ze, was 'onaanvaardbaar tiskant' geworden, en moest 'achteruit'. (Ibid.9)

De samenstellers van de bundel kenden elkaar niet vóór ze bijeenkwamen om over de plannen voor hum boek te spreken. Ze hoorden niet bij een genootschap tegen euthanasie, en ze hingen geen partij aan die zich tegen de legalisering van hulp bij zelfdoding verzette. Ze hadden zich tot dan toe allemaal eenling gevoeld in hun aversie tegen de ontwikkelingen binnen de euthanasiediscussie. Daarom vonden ze het des te belangrijk zich publiekelijk te weren tegen de legalisering van hulp bij zelfdoding, zoals Chabot die geboden had. Onder hulp bij zelfdoding verstaan de auteurs overigens niet alleen wat de wet als hulp bij zelfdoding beschouwt - iemand bij diens zelfdoding assisteren, zoals Chabot dat deed -, maar ook wat in de medische en in de juridische wereld onder euthanasie verstaan wordt: opzettelijke levensbeëindiging op verzoek door een arts. ${ }^{8}$

De auteurs van Als de dood voor het leven verzetten zich tegen de ideeën over de dood die volgens hen ten grondslag lagen aan de destijds nog in het verschiet liggende legalisering van euthanasie en hulp bij zelfdoding. Ten eerste weren ze zich tegen het idee dat de dood 'maakbaar' zou zijn. Als gevolg van de 'propaganda' voor legalisering van euthanasie zou de dood het karakter hebben gekregen van een oplossing van een probleem: de meeste mensen zouden de dood beschouwen als een instrument dat ze naar believen kunnen gebruiken om een einde te maken aan een onwenselijke toestand. Ten tweede bekritiseren de auteurs de zelfoverschatting van artsen die denken dat zij bepalen kunnen wanneer het lijden van een patiënt uitzichtloos en ondraaglijk geworden is. Daarmee lijken deze artsen te zeggen dat het in hún macht ligt te beslissen wanneer het leven van een patiẻnt niet langer verlengd hoeft te worden. Legalisering van euthanasie zou deze aanmatiging sanctioneren. Ten slotte hekelen de schrijvers van Als de dood voor het leven de 'ideologie van de zelfbeschikking' die maakt dat mensen denken dat ze ongestraft zelf het einde van hun leven kunnen bepalen. De meeste mensen, stellen de auteurs, beseffen niet dat je niet straffeloos het taboe op zelfdoding doorbreken kunt. De kritiek van Achterhuis, Goud, Koerselman, Otten en Schalken richt zich, kort samengevat, op het verlangen naar macht van zowel patiënten als artsen: "[...] de macht die mensen van elkaar willen dat zij over elkaar mogen hebben.' (Achterhuis e.a. 1995:9)

De vijf auteurs hebben een duidellijk idee hoe hun bijdrage aan het openbaar debat moet worden opgevat. Hun bundel, schrijven ze, 'geeft historisch, fillosofisch, psychiatrisch, juridisch en literair voedsel aan het 
debat over hulp bij zelfmoord". (Ibid.) Die specificaties komen op het eerste gezicht overeen met de beroepen en achtergronden van de verschillende auteurs. Achterhuis is filosoof, Goud studeerde filosofie en theologie, Koerselman is psychiater, Schalken jurist en Otten dichter en schrijver. Achterhuis, Goud, Koerselman en Schalken leverden artikelen. die betrekking hebben op hun vak. Maar Otten uitte zijn mening niet in een gedicht of een verhaal. Zijn bijdrage is, net als die van zijn collega's, beschouwend van aard. Volgens Chris Rutenfrans, een van de recensenten van de bundel en eveneens een tegenstander van de legalisering van euthanasie, vertoont Ottens essay echter duidelijk literaire aspecten. Dat geldt, zegt hij, wooral voor de stijl van Ottens essay. Otten zou de lezer niet op een verstandelijke, maar op een gevoelsmatige manier van de verwerpelijkheid van hulp bij zelfdoding willen overtuigen. Daarmee geeft Rutenfrans niet alleen aan dat hij van mening is dat gevoel en verstand tot twee verschillende domeinen behoren, maar ook dat de literatuur tot het gebied van het gevoel hoort. Otten haalt volgens hem de discussie over hulp bij zelfdoding en euthanasie uit het bereik van het verstand en plaatst deze in het bereik van het gevoel. (Rutenfrans 1995:13-15)

Ottens kritiek richt zich inderdaad in de eerste plaats op de al te rationele en technische manier waarop er in Nederland over euthanasie en hulp bij zelfdoding gesproken zou worden. Artsen, zegt hij in Als de dood voor het leven, spreken makkelijker over hun technische kunnen dan over de macht die zij over een patiënt hebben. Ze vermijden het ook te praten over de angsten en de onzekerheid die met euthanasie gepaard gaan. De meeste mensen - artsen zowel als niet-artsen - beschouwen de dood liever als een praktische uitweg dan als een tragische gebeurtenis. Omdat de discussie gevoerd wordt op een zuiver rationele wijze, gat men voorbij aan het feit dat mensen weliswaar altijd verlangen naar zelfbeschikking, maar dat onze levens gestuurd worden door het lot. Als de problemen die ontstaan door de legalisering van euthanasie en hulp bij zelfdoding tot uitdrukking komen binnen de context wan een literaire tragedie, beseffen we dat we veel minder autonoom zijn dan we denken. Want alleen de tragedie, stelt Otten, maakt duidelijk dat hoe meer macht mensen zich toe-eigenen, hoe minder greep zij op wil én leven hebben. (Otten 1995d:61-65) Door in te werken op ons tragisch besef, zegt Otten, plaatst de tragedie leven en dood in het juiste perspectief. Als voorbeeld noemt hij het drama Antonius and Cleopatra van Shakespeare, dat volgens hem 'het nut van de huivering' dient. Huivering laat zien dat de dood geen praktische oplossing kan zijn. 'Een cultuur moet bijdragen aan de huiver,' zegt Otten in een interview met Jan Tromp in de Volkskrant in 1995 naar aanleiding van de publicatie van Als de dood voor het leven, 'opdat de dood, de zelfmoord het mysterie blijft die het is.' 
Ottens tweedeling in het zuiver rationeel denken enerzijds en de literatuur, in casu de tragedie, anderzijds, sluit aan op de discussie over de aard en de functie van de literatuur en die van de filosofie. In die discussie worden filosofie en literatuur dikwijls als antagonisten beschouwd. Er bestaat een oude strijd tussen filosofie en poëzie, schrijft Plato in boek $\mathrm{X}$ van De republiek. Met die strijd bedoelt hij het conflict tussen wat hij kennis en opvatting, Zijn en schijn noemt. Dit conflict is tegelijk kentheoretisch en ethisch van aard. Waar de literatuur met haar aandacht voor de subjectieve ervaring en het gevoel "het derde stadium vanaf de waarheid' vertegenwoordigt, brengt alleen de filosofie het contact met het ware Zijn tot stand. (Plato: De republiek, boek X:599) Daardoor biedt de filosofie niet alleen ware kennis van het Zijn zelf, maar ook, zoals Martha Nussbaum het in een exposé over Plato uitdrukt, ware kennis omtrent "het leven en de manier waarop mensen leven moeten". (Nussbaum $1992: 15)^{9}$ De tragedieschrijvers houden zich volgens Plato slechts met schijn bezig en bieden daarom geen kennis van de juiste manier van leven. Kunst leidt af van de enige echte kennis, de kennis van het Zijn. In de geschiedenis van de westerse filosofie heeft de discussie over de mogelijkheid van ware kennis van het Zijn zich toegespitst op de tweedeling in directe ervaring en het gevoel enerzijds, en het abstracte, strikt rationele denken anderzijds. Daarbij verklaarde men de literatuur, als zetel van de directe, concrete ervaring, tot de tegenpool van de filosofie, het domein van het strikt rationele denken. ${ }^{10}$

Otten schaart zich, zoals Rutenfrans opmerkt, in zijn kritiek op de euthanasiediscussie aan de kant van de literatuur. In een lezing die Otten begin 1995 hield voor de Stichting Literaire Activiteiten Amsterdam (SLAA) en die in maart van dat jaar afgedrukt werd in Vrij Nederland, richt hij zich tegen de filosofie die, zegt hij, sinds Plato meent dat de wereld op een zuiver rationele manier analyseerbaar, inzichtelijk en beheersbaar is. Dat levert volgens Otten geen kemnis van de werkelijkheid op. Integendeel - de werkelijkheid is zo complex en zo ondoorzichtig dat een analyse haar alleen maar vertekenen kan. Kennis wan de werkelijkheid heeft, meent hij, niets te maken met abstracte begrippen en ideeën, en nog minder met wetenschappelijke wetten en abstracte constructies. Omdat de filosofie ons eeuwenlang heeft laten denken dat wij de werkelijkheid en ons eigen leven kennen, bedwingen en bepalen kunnen door middel van abstracte redeneringen, zijn wij volkomen ten onrechte gaan denken dat wij heer en meester zijn over het leven. Onze hoogmoed is zo ver doorgeschoten dat we nu zelfs menen dat wij ook over de dood beschikken kunnen. In werkelijkheid, zegt Otten, beschikt het lot, een buitenmenselijke kracht, over leven en dood.

Echte kennis van de werkelijkheid biedt volgens Otten alleen de trage- 
dîe. De tragedie verkláárt niet de werkelijkheid, ze doet ons die ondergaan. Ze laat ons zien hoe complex de werkelijkheid is en hoe moeilijk het is eenduidige beslissingen met betrekking tot het juiste handelen te nemen. De tragedie, benadrukt Otten, biedt ons kennis die niet door reflectie tot stand komt, maar die alleen in de concrete ervaring te vinden is. Die kennis heeft te maken met de notie dat mensen hun eigen levens niet bepalen kunnen. Volgens Otten draait het in de tragedie voortdurend "om de botsing tussen het verlangen van mensen om "zelf hun eigen werk te zijn", en de kracht van de "noodzakelijke machten". (Otten 1995d:63-64) De tragedie doet ons beseffen dat ons verlangen naar zelfbeschikking weliswaar mateloos groot is, maar dat het geloof erin op een misvatting berust. De tragedie maakt bovendien duidelijk dat ons vertrouwen in de menselijke ratio misplaatst is. Niet wij bepalen leven en dood; leven en dood worden voor ons bepaald. De tragedie verschaft ons die kennis niet door middel van rationele overwegingen, maar door directe herkenning.

In 1994, kort voor de verschijning van Als de dood voor het leven, publiceerde Otten Ons mankeert niets, een roman warin een van de protagonisten met medeweten van zijn omgeving zichzelf doodt. Deze roman wordt op de achterflap een 'gewetensonderzoek' genoemd - een 'gewetensonderzoek van een man die zich geplaatst weet voor een gevreesde vraag: wat doe je als je weet dat iemand dood wil?" In een schriftelijke discussie, die het dagblad Trouw organiseerde naar aanleiding van de verschijning van deze roman, noemt Otten zijn boek uitdrukkelijk een tragedie. In diezelfde discussie schrijft hij dat een literaire tekst veel beter dan een essay of een betoog de dagelijkse ervaring weergeeft, en dus ook de concrete problemen en vragen rond euthanasie en hulp bij zelfdoding. Ons mankeert niets geeft volgens Otten zelf zijn standpunt inzake de legalisering van euthanasie beter weer dan zijn essays of zijn krantenartikelen. Die kennis, zegt hij, heeft alles te maken 'met een idee dat mensen hun eigen werk niet zijn'. (Otten 1995a)

\section{Tussen wet en werkelijkheid}

Op 1 april 2002 is de wet toetsing levensbeëindiging op verzoek en hulp bij zelfdoding in werking gesteld. Dat heeft niets veranderd aan Ottens ideeën over legalisering van euthanasie en hulp bij zelfdoding. Integendeel, Otten heeft sinds de jaren negentig zijn mening, uitgaande van de onmogelijkheid van het recht op zelfbeschikking en de zinloosheid van de filosofie inzake euthanasie, aangescherpt. In zijn in 2003 , verschenen boek De bedoeling van de verbeelding, dagboekaantekeningen uit de 
zomer van 2002, bevestigt hij zijn overtuiging dat westerlingen zich steeds zo veel mogelijk proberen te ontdoen van niet-rationele gevoelens en de invloed van buitenmenselijke, irrationele krachten. 'We hebben met een enorme krachtsinspanning de zonde weggedacht,' schrijft hij bijvoorbeeld. 'Zondig weet je jezelf als er een wet is, die menselijkerwijs niet naleefbaar is.' (Otten 2003:71) Daarmee verbonden blijft zijn overtuiging dat mensen, anders dan ze graag denken, onder geen enkele omstandigheid het recht hebben een einde te maken aan hun eigen leven of dat van een ander. (Ibid.:86)

In de verschillende boeken, kranten- en tijdschriftartikelen die sinds de voorbereiding en de invoering van de wet in 2001 over euthanasie en hulp bij zelfdoding verschenen zijn, komt dikwijls de vraag naar de interpretatie van de zorgvuldigheidseisen uit de wet aan de orde.. "Daarbij wordt gewezen op een spanning tussen wet en werkelijkheid, of beter, tussen de abstracte, strikt rationele theorie en concrete, praktische ervaringen. In de wet staat onder andere dat euthanasie slechts geoorloofd is als er sprake is van uitzichtloos en ondraaglijk lijden. Sommige artsen stellen dat het lastig is een algemene definitie te geven van termen als "lijden' en 'uitzichtloosheid'. J.A. de Wit betoogde in 2002 in een artikel in Medisch Contact dat de onzorgvuldige formulering van de begrippen die in de wet gebruikt worden, mede debet is aan het 'afglijden op een hellend vlak'. (De Wit 2002:1664-1666) 'Er is in de medische wereld geen consensus over de inhoud van ondraaglijk lijden,' schreef begin 2003 een aantal huisartsen, allen voorstanders van de legalisering van euthanasie. (Kenter, Struis en Wassenberg 2003:845-848)

G.A. den Hartogh wijst in het kader van onderzoeken naar het succes van de Nederlandse regulering van euthanasie en hulp bij zelfdoding op de moeilijkheid van het bereiken van een zo breed mogelijke consensus over de interpretatie van de zorgvuldigheidseisen. "Op dit punt schiet onze kennis te kort,' schrijft hij, want de interpretaties van de algemene voorschriften door de individuele artsen lopen uiteen, vooral waar het gaat om 'de beoordeling van de vrijwilligheid en weloverwogenheid van verzoeken van patiënten, en van de ondraaglijkheid en uitzichtloosheid van het lijden.' (Den Hartogh 2002:24I) Ton Vink komt op grond van filosofische beschouwingen over de begrippen 'zelfbeschikking'en 'autonomie' tot de conclusie dat de praktijk niet ondergeschikt gemaakt kan worden aan de wet. (Vink 2002b:35)

Verschillende auteurs maken bovendien duidelijk dat er behoefte is aan een ander soort discussie over de legalisering van euthanasie en hulp bij zelfdoding. Die discussie mag zich niet langer beperken tot abstracte definities en algemene bepalingen, maar moet ingaan op de concrete ervaringen van individuele artsen, patiënten en hun naasten. In die discus- 
sie zouden bijwoorbeeld, zoals Aart Hoogerwerf schrijft, woorden moeten voorkomen die veel gebruikt worden in de dagelijkse praktijk, maar die nauwelijks of niet te vinden zijn in verhandelingen over de medische ethiek of gezondheidsethiek. Onder dergelijke woorden verstaat hij 'barmhartigheid' en 'mededogen'. (Hoogerwerf 1999:119)

Tegelijkertijd wordt er gewezen op het belang van de literatuur voor de geneeskunde. De samenstellers van Ziektebeelden, een verzameling essays over de verhouding tussen literatuur en geneeskunde, wijzen expliciet op het verschil tussen theorie en literatuur. In hun introductie schrijven ze dat romans en verhallen vastgeroeste ideeën aan het wankelen kunnen brengen, omdat die licht werpen op de complexiteit van de dagelijkse ervaringen: "Fictie levert geen antwoorden op, natuurlijk niet, maar het zet artsen aan het denken en bevrijdt ze misschien wel uit een eenzijdig medisch denkraam. Fictie biedt geen zekerheden, maar doet juist twijfelen. De beelden/verhalen van de literatuur laten medici meer begrijpen van de eigen overtuigingen en van die van anderen, waardoor zij weer kritisch worden over de eigen overtuigingen." (Meulenberg e.a.2002:14) De bundel De taal van het gevoel, die uit vijfentwintig essays over psychilatrie en literatuur bestaat, is volgens de samenstellers bedoeld om psychiaters te bevrijden uit een eng-wetenschappelijk keurslijf opdat ze zich meer richten op de particuliere situatie van hun cliënten. (Oderwald e.a. 2003)

Nieuw is deze aandacht voor de verhouding tussen het lezen van verhalen en de omgang met de concrete werkelijkheid niet. Martha Nussbaum $(1986,1990)$ laat zien dat de literatuur ons bij het denken over levensvragen biedt wat in de filosofie ontbreekt, zoals spanning, afwisseling, empathie en affectie. Zonder fictie, zegt zij, is onze ervaring te beperkt om tot juiste oordelen te komen. Paul Ricoeur $(1986,1990)$ benadrukt dat het lezen van romans ons in staat stelt samenhang en diepte te geven aan onze dagelijkse ervaringen, waardoor wij kunnen beoordelen of die ervaringen goed of slecht zijn. Volgens Hans Robert Jauß (1994) vergelijken we bij het lezen onze ervaringen met die van de fictieve personages, en proberen we op die manier tot morele oordelen en beslissingen te komen. Adam Zachary Newton (1995) beschouwt de verhouding tussen het narratieve en ethiek als intrinsiek en noodzakelijk, en Anthony Cunningham (2001) stelt dat de literatuur ons niet alleen kan laten zien welke problemen werkelijk belangrijk zijn, maar ook wat voor soort oplossingen we voor die problemen moeten zoeken.

Dergelijke opvattingen spelen ook een rol binnen het euthanasiedebat. Anne-Mei The hecht grote waarde aan het verhaal bij de verzorging van ongeneeslijk zieken. 'De verhalende taal,' schrijft zij, 'lijkt de enige manier om uitdrukking te geven aan het belang van de context en de lo- 
kale redelijkheid van uitvoeringspraktijken." (The 1999:23) Een discussie over euthanasie op basis van strikt rationele argumenten beschouwt The in de meeste gevallen als zinloos. (The 1997, 1999) Jean-Pierre Wils (2000) meent dat de ethiek van het sterven gebaat is bij "literaire belichting' en Guy Widdershoven (2000) pleit voor het betrekken van verhalen bij beslissingen rond euthanasie. Ook Dick Willems wijst op het belang van de narratieve ethiek inzake euthanasie. 'Narratieve ethiek', zegt hij, 'beziet morele vragen vanuit het perspectief van het levensverhaal. van een patiënt en maakt samenhangendheid daarmee tot een belangrijk ethisch-esthetisch criterium om levens te beoordelen.' (Willems 2003:14) Willems beschouwt euthanasie alls een tragedie waarin tragische tegenstellingen en tragische, dat wil zeggen, onoplosbare problemen een grote rol spelen. Artsen, zegt hij, passen euthanasie toe als ze niets anders meer kunnen doen, maar ze doen dat in de meeste gevallen met tegenzin: 'Ze volgen de zorgvuldigheidseisen, maar toch blijft het knagen - de rechtvaardiging is nooit volledig.' (Ibid.) Hij verwijst naar Katryn Hunter, die stelt dat alle betrokkenen bij euthanasie de rol moeten krijgen van het koor in een tragedie." ${ }^{3}$ Dit koor, schrijft hij, "lost het probleem niet op (want dat is onmogelijk), maar bespreekt en herhaalt wat er gebeurt en geeft het betekenis'. (Ibid.:16)

Dergelijke vergelijkingen en verbindingen van literatuur en medischethische discussies maken het zinvol Ottens tragedie Ons mankeert niets opnieuw onder de aandacht te brengen. Als het lezen van een literaire tekst, zoals bovengenoemde auteurs betogen, helpen kan bij het innemen van een bepaalde houding ten opzichte van euthanasie, en als Otten zelf zijn roman beschouwt als een alternatief voor de discussie over de legalisering van euthanasie en hulp bij zelfdoding, zoals die in essays en artikelen plaats vindt, dan is het op zijn minst de moeite waard na te gaan hoe Ons mankeert niets ons kan laten zien hoe we kunnen omgaan met vragen betreffende de kunstmatige dood. Maar dat is niet de enige reden om het boek te lezen en te herlezen, zoals in deze studie gebeurt. 'Een goed kunstwerk,' schrijft Widdershoven, 'geeft steeds weer te denken, leidt tot een geschiedenis van interpretaties.' (Widdershoven 2002:684) Het lezen en herlezen van Ons mankeert niets, dat gaat over een Nederlandse arts die geconfronteerd word met zowel met euthanasieverzoeken van zijn patiënten als met de zelfdodingsplannen van zijn voorganger, kan om al deze redenen nieuw licht werpen op de kwesties waarmee zowel artsen als niet-artsen te maken krijgen wanneer iemand een einde aan zijn of haar leven wil maken.

Ons mankeert niets is niet de enige Nederlandstalige roman over euthanasie. Willy Corsari publiceerde in 1933 De man zonder uniform. Het hoofdrhema van dit boek is de vraag in hoeverre we ons naar geschreven 
wetten dan wel naar ongeschreven wetten - de wetten van het hart moeten richten. Het probleem van de toegepaste dood - het woord 'euthanasie' komt in de roman niet voor - vormt een onderdeel van deze vraag. In 1992 verscheen Dierbaar venijn, een roman van Rudolf Geel, waarin een dochter haar vader op diens verzoek een 'zachte dood' laat sterven. Anders dan in De man zonder uniform gaat dit boek expliciet over euthanasie. De dochter geeft pas na lange aarzeling toe aan de wens van haar vader, en wordt na zijn dood overweldigd door de onherroepelijkheid van haar daad. ${ }^{44}$ Geels roman draagt alle aspecten van een tragedie, zoals door Otten geformuleerd, in zich: ook hierin gaat het om tragische tegenstellingen en oplosbare problemen. Ons mankeert niets en Dierbaar venijn laten zich met elkaar vergelijken. In dit proefschrift wordt alleen ingegaan op Ons mankeert niets, omdat Otten als enige Nederlandse auteur zijn in essays uiteengezette opvattingen over het belang van de tragedie inzake de euthanasiediscussie heeft uiteengezet in een roman, en zijn motieven daartoe toegelicht heeft in artikelen. Zijn roman kan gelezen worden als een uitdrukking van zijn opvattingen over de legalisering van euthanasie, ook al biedt de roman, zoals Otten het formuleert, andere kennis dan 'krantenkennis'.

Dat laatste roept echter onmiddellijk een antal nieuwe problemen op. Het schrijven van een roman is geen eenduidige bezigheid. Een roman, stelt bijvoorbeeld Wayne Booth, verwijst nooit alleen naar zichzelf. De verhouding tussen de concrete werkelijkheid en een roman is ambigu - leven en kunst beïnloeden elkaar. ${ }^{15}$ Een roman kan daarom. geen simpele handleiding voor het leiden van een goed leven zijn. Dezelfde verhouding bestaat tussen een roman en een lezer. De betekenis van een boek ontstaat bij het lezen. Lezen is echter geen neutrale, onafhankelijke of waardevrije bezigheid. Want hoewel lezers voor het scheppen van betekenis afhankelijk zijn van de vorm en inhoud van het boek, brengen zij bij de interpretatie van de roman hun eigen achtergronden en ervaringen mee. Maar als we Ons mankeert niets lezen om een algemeen antwoord te vinden op de algemene vraag "wat doe je als je weet dat iemand dood wil?" kunnen we niet volstaan met een persoonlijke interpretatie van de roman. $\mathrm{Nu}$ is dat ook niet nodlig. Een roman brengt niet slechts de gedachten van de auteur tot uitdrukking, net zomin als hij alleen maar aanleiding geeft tot de strikt persoonlijke interpretaties van de verschillende lezers. Widdershoven benadrukt dat een kunstwerk ons alleen iets leren kan 'doordat het verschillende interpretaties oproept. We leren iets van een kunstwerk doordat we deel uitmaken van een spel van interpretaties. Een kunstwerk heeft meer dan één boodschap.' (Widdershoven 2002:683, cursivering in origineel)

Het is bovendien de vraag of we bij het interpreteren van een roman 
de filosofie buiten spel moeten laten. Er zijn verschillende redenen waarom we filosofie en literatuur als bondgenoten beschouwen kunnen. Veel filosofen zijn, zoals Stephen $\mathrm{K}$. Levine het uitdrukt, dichters geworden. Sinds Nietzsche en Heidegger, zegt hij, heeft de filosofische taal niet langer de doorzichtigheid van een wiskundige formule en bezigt de filosofie niet langer uitsluitend abstracte, strikt rationele redeneringen. ${ }^{16}$ Marianne Boenink komt in haar dissertatie Boekenwijsheid. Filosofie, literatuur en politicke oordeelsvorming tot de conclusie dat sommige teksten 'een geschikt voertuig voor educatie van de politieke en ethische oordeelsvorming zijn'. Tot die teksten rekent zij zowel filosofische als literaire geschriften. (Boenink 2000:227)

Een van de wijsgeren die filosofie en literatuur op één lijn stellen, is de Fransman Maurice Merleau-Ponty (1908-1961). Zowel Iiteratuur als filosofie, zegt hij in het woord vooraf van Phénoménologie de la perception, wil de betekenis van de wereld in wording vatten. Noch de literatuur, noch de fillosofie staat boven de werkelijkheid. Beide brengen de werkelijkheid juist tot uitdrukking. De taak van de filosoof kan daarom niet wezenlijk onderscheiden worden van die van de literaire schrijver. Zowel de filosoof als de schrijver richt zich op de ervaring van de wereld zoals die ontstaat vóór het denken over de wereld. In het denken van Merleau-Ponty, schrijft Eric Matthews, kunnen romans filosofisch worden, omdat we het schrijven van een roman als een vorm van fenomenologisch onderzoek mogen beschouwen. ${ }^{17}$

In zijn geschriften gaat Merleau-Ponty met behulp van filosofie en kunst op zoek naar de concrete fundamenten van de ervaring en de reflectie. Daarmee bevestigt hij, zoals Levine het uitdrukt, de samenhang tussen filosofie en kunst in hun verhouding tot het Zijnde. ${ }^{18}$ Het Zijnde moeten we begrijpen als de concrete, waarneembare dagelijkse werkelijkheid, waarvan we vanaf onze geboorte deel uitmaken. Merleau-Ponty biedt daarmee een ontologisch fundament voor het belang van de kunst. Hij maakt duidelijk waarom en hoe de literatuur, op grond van de structuur van de werkelijkheid, ons helpen kan met belangrijke levensvragen om te gaan. Daarmee gaat hij verder dan de meeste auteurs die op het belang van de esthetica voor de ethica wijzen. Bovendien laat hij in zijn studies van onze concrete erwaringen zien hoe het algemene en het particuliere met elkaar verbonden zijn. Abstracte theorie en concrete werkelijkheid hoeven volgens Merleau-Ponty niet haaks op elkaar te staan, en tussen wet en werkelijkheid hoeft niet per definitie een discrepantie te bestaan. Ook het algemene en het particulier zijn bij Merleau-Ponty geen elkaar uitsluitende begrippen. 
Deze studie is als volgt opgezet. In het tweede hoofdstuk ga ik in op Ottens theoretische stellingname tegen de legalisering van euthanasie en hulp bij zelfdoding, zoals hij die verwoord heeft in verschillende essays en krantenartikelen. ${ }^{19}$ Ottens theoretische uiteenzettingen, die hijzelf van beperkte waarde acht, maar die een expliciete bijdrage aan het openbare debat leveren, liggen ten grondslag aan de roman Ons mankeert niets en hebben bijna allemaal te maken met de vermeende discrepantie tussen wet en werkelijkheid. Omdat de zorgvuldigheidseisen die deel uitmaken van de wet de kernpunten vormen van de discussies over euthanasie zoals die ook na de invoering van de wet gevoerd worden, zijn de paragrafen van dit hoofdstuk opgezet aan de hand van die eisen.

In de twee daarop volgende hoofdstukken staat Ons mankeert niets centraal. Omdat Otten literaire teksten belangrijker acht dan filosofische, krijgt zijn roman meer aandacht dan zijn essays. In de verhandelingen over Ottens roman wil ik laten zien dat dit boek meer tot uitdrukking brengt dan zijn theoretische artikelen, maar dat het lezen van het verhaal op cruciale punten tot conclusies leidt die afwijken van de conclusies die Otten in zijn essays trekt. In het derde hoofdstuk wordt de roman gelezen op de manier waarop Otten dat van ons lijkt te verlangen: de personages worden, in navolging van Ottens uitspraken over de roman, beschouwd als tragische personages wier levens bepaald worden door het lot. Het vierde hoofdstuk laat zien dat de roman ook op een andere manier gelezen kan worden. In deze lezing staat de alledaagsheid, of zo men wil, de particulariteit van de hoofdpersonen en hun ervaringen centraal. De eerste lezing noem ik een tragische lezing, de tweede een historische, omdat in de tweede lezing de personages gezien worden als mensen die in deze tijd zouden kunnen leven en de roman gelezen wordt als niet meer dan een verhaal over hun dagelijkse, strikt particuliere en situatieve ervaringen.

De inzichten die in de tweede lezing van Ons mankeert niets opgedaan worden, vragen om een adequate filosofische uitwerking. Die komt tot stand met behulp van de ideeën van Maurice Merleau-Ponty. In het vijfde hoofdstuk staat daarom zijn filosofie centraal. In dit hoofdstuk wordt niet de ontwikkeling van zijn denken weergegeven. Evenmin worden hier de verschillende thema's of aspecten van zijn geschriften apart behandeld. Dat is reeds vele malen en op uitmuntende wijze gedaan, zoals bijvoorbeeld door Remigius Kwant, James Edie, Matt Dillon en Jenny Slatman. Merleau-Ponty noemt in het woord vooraf van Phénoménologie de la perception de filosofie, net als de beeldende kunst en de literatuur, 'de verwerkelijking van een waarheid'. (Merleau-Ponty 1945:XV) 20 De fi- 
losofie, zegt hij, "is een moeizame arbeid zoals het werk van Balzac, van Proust, van Valéry of van Cézanne - door dezelfde stijl van aandacht en verwondering, door dezelfde eis van bewustzijn, door dezelfde wil om de zin van de wereld of van de geschiedenis in haar wording te vatten.' (Ibid.:XVI) ${ }^{2:}$ In dit proefschrift wordt gekeken naar de manier waarop filosofie en literatuur inzicht kunnen geven in een bepaald ethisch probleem, waarbij ethiek niet begrepen wordt als een stelsel van normen, maar, zoals Cunningham de morele filosofie omschrijft, als een zoektocht naar 'the heart of what matters', 'het hart van wat ertoe doet'. Een huwelijk tussen literatuur en filosofie, schrijft Cunningham, helpt ons aan 'een rijkere conceptie van morele filosofie, die het hart treft van wat belangrijk is in een menselijk leven en karakter". (Cunningham 2001:5) ${ }^{22}$ Ik gebruik de filosofie van Merleau-Ponty letterlijk als een manier of een methode om al lezend in Ottens roman een houding te bepalen ten opzichte van de vragen die niet alleen Otten, maar ook veel Nederlandse artsen zich stellen: wat moet je doen als je weet dat iemand sterven will? Hoe kunnen we bij onze zoektocht naar een juiste manier van handelen in deze kwestie recht doen aan zowel de particuliere, situatieve werkelijkheid als de algemene regels van de wet?

Die mogelijke houding komt ter sprake in het zesde, concluderende hoofdstuk. Daarin wordt nagegaan hoe we op grond van Ottens essays, uiteenlopende lezingen van zijn roman en met behulp van Merleau-Ponty's filosofie, binnen de bepalingen van de wet, maar zonder de concrete werkelijkheid uit het oog te verliezen, in kunnen gaan op de vraag van een patiënt naar een zachte dood.

Met beide lezingen, die eveneens aan de hand van de zorgvuldigheidseisen zijn ingedeeld, is uitdrukkelijk geen literatuurwetenschappelijk doel verbonden. Deze studie richt zich evenmin op de beoordeling van Ottens boek aan de hand van de traditionele eisen die gesteld worden aan een tragedie. Ottens stijl, de opbouw van het verhaal, de vraag naar eenheid van tijd en plaats of de wijze waarop de roman de emoties van de lezer bespeelt, komen hier niet aan de orde. Omdat Otten er zelf steeds de nadruk op legt dat hij met zijn roman een bepaalde kennis wil overbrengen en ik in deze studie na wil gaan wat een roman, en in het bijzonder Ons mankeert niets ons leren kan met betrekking tot vragen betreffende euthanasie en hulp bij zelfdoding, heb ik gekozen voor een inhoudelijke lezing van Ottens roman.

Filosofie en literatuur worden hier niet als tegenpolen beschouwd, maar als aanvullingen op elkaar. Daarom heb ik voor een stijl gekozen die, hoop ik, zoveel mogelijk recht doet aan zowel de filosofie als de literatuur. Ook wat dit aspect betreft verwijs ik naar Cunningham, die stelt dat 'een droge, zeer technische [...] manier van schrijven geen voor" 
waarde is voor fillosofisch inzicht, zelfs als heel goede filosofieën aan deze kwaal geleden hebben. [...] Alles wat het waard is om gezegd te worden, is het waard om op een simpele, duidelijke en elegante wijze te zeggen.' (Cunningham 2001:4-5) ${ }^{23}$ Daar wil ik onmiddellijk aan toevoegen dat het weliswaar mijn streven geweest is zo duidelijk mogelijk te schrijven, maar dat alleen de lezer bepalen kan of $i k$ in die opzet geslaagd ben. 


\section{De kritiek op de legalisering van euthanasie en hulp bij zelfdoding in essays van Willem Jan Otten}

In artikel 2, hoofdstuk II van de huidige wet op euthanasie, staan de bepalingen onder welke een arts ongestraft mag overgaan tot euthanasie. ${ }^{2.4}$ Het eerste onderdeel van artikel II bevat de zogenaamde zorgvuldigheidseisen. Aan deze eisen moeten artsen voldoen wanneer zij niet voor het beëindigen van het leven van een patiënt gestraft willen worden. In het tweede onderdeel wordt vastgesteld wanneer euthanasie wettelijk toegestaan is als een patiënt niet langer in staat is zijn of haar wil te uiten, maar wel eerder al een schriftelijke verklaring inzake zijn of haar levenseinde afgelegd heeft. Het derde en het vierde onderdeel hebben betrekking op de euthanasie van minderjarige patiëntenn. ${ }^{25}$

In zijn essays over euthanasie toont Otten zich niet alleen een tegenstander van actieve euthanasie, maar vooral ook van de wettelijke regeling daarvan. De wettelijke bepalingen omtrent de kunstmatige dood, meent hij, zijn een voorbeeld van de manier waarop in onze cultuur de ratio het van de concrete ervaring gewonnen heeft. Het wettelijk regelen van euthanasie beschouwt hij als de rationalisering ten top. De verschillende regels ziet hij als de zichtbare gevolgen van een dolgedraaide, rationele discussie over de dood. (Otten 1995b:46)

In dit hoofdstuk wordt Ottens kritiek op de euthanasiediscussie, zoals hil die in verschillende essays en artikelen geuit heeft, gepresenteerd via de verschillende bepalingen van de wet. Hierdoor kunnen Ottens bezwaren tegen de legalisering van euthanasie en hulp bij zelfdoding in een actuele en concrete context besproken worden. Omdat Otten zich in zijn essays over euthanasie alleen uitlaat over die aspecten van wettelijk toegestane euthanasie die genoemd worden in de zorgvuldigheidseisen, hoofdstuk II, artikel 2, punt ta tot en met e, en in het tweede onderdeel van artikel 2, staan in dit hoofdstuk deze zorgvuldigheidseisen centraal. 
De eerste zorgvuldigheidseis wit het eerste onderdeel van hoofdstuk II, artikel 2 van de wet toetsing levensbeeindiging op verzoek en hulp bij zelfdoding verlangt van een arts die overgaat tot euthanasie, dat hij of zij 'de overtuiging heeft gekregen dat er sprake was van een vrijwillig en weloverwogen verzoek van de patiënt".

Deze eis moet malversaties van de kant van de arts voorkomen. Volgens sommige voorstanders van de invoering van de wet op euthanasie heeft de eis ook te maken met het recht op eerbiediging van de persoonlijke levenssfeer, zoals dat in de Grondwet is opgenomen. Tot de persoonlijke levenssfeer rekenen zij het recht op zelfbeschikking over de eigen levenswijze, en daaronder valt volgens hen ook het recht van ieder mens om over zijn of haar eigen levenseinde te beslissen. "In het licht van [her] zelfbeschikkingsrecht over eigen levenswijze', staat bijvoorbeeld te lezen in de aanwijzing voor het invullen en het gebruik van de euthanasieverklaring en de euthanasiepas van de Nederlandse Vereniging voor een Vrijwillig Levenseinde ( $N V V E$ ), "acht de NVVE het vanzelfsprekend dat de mens ook zelf mag beslissen over de wijze en het tijdstip waarop hij wil sterven.'

Het idee van het recht op zelfbeschikking druist volgens Otten in tegen drie essentiële en onderling samenhangende aspecten van het menselijk leven. Het eerste aspect is dat het denken en handelen van de mens, in tegenstelling tot wat wij doorgaans denken, niet door zuiver rationele overwegingen bepaald wordt. Ons leven is veeleer een geheel van irrationele beslissingen en tegenstrijdige gevoelens, waarin geen logica te ontdekken valt. (Otten 1995b:47) Het tweede aspect is de afhankelijkheid van wat Otten in zijn verschillende essays over euthanasie 'het lot' noemt. Het lot is het 'buitenmenselijke' dat bepaalt wanneer wij sterven. (Otten 1995d:69) Het derde aspect is dat we 'bestaan voor zover we met anderen samenhangen". (Otten 1995b:48) Dat betekent dat het leven en de dood geen individuele aangelegenheden zijn, en dat iemands dood onherroepelijk gevolgen heeft voor anderen. Om deze reden is het, meent Otten, een illusie te denken dat we op volkomen rationele en weloverwogen wijze, wrijwillig en zelfstandig over ons levenseinde kunnen en mogen beslissen.

\section{Het mysterie van de ziel}

'Er is', zegt Otten in zijn SLAA-lezing uit 1995, "een spreeuwegekwetter van doodswensjes opgestoken, een soort naarstig gefillosofeer over wanneer het leven nog wél, en wanneer niet meer, en hoe er dan van af, met een prik of uit een kelk of dankzij een druppelend infuus, en oude 
vrouwtjes in het verpleegtehuis, zouden we die niet zonder dat ze het zelf beseffen per infuus... en al deze voorstellingen, van kranige presentatrices en montere bejaarden, van mensen die geen van allen bezig zijn om dood te gaan, het zijn in mijn ogen allemaal manieren om je eigen einde en dat van, klaarblijkelijk overtollige, anderen, voor te stellen als een uitweg.' (Otten 1995b:46)

De discussies over het tijdstip warop het leven geen zin meer heeft, laten volgens Otten zien dat woorstanders van de legalisering van euthanasie de mens als een zuiver rationeel denkend wezen beschouwen.

Otten wijst het idee van de zuiver rationeel denkende en handelende mens van de hand. Volgens hem is dit idee in zwang geraakt onder invloed van de westerse, postsocratische filosofie. Hij beschuldigt die fillosofie ervan dat zij ons ten onrechte laat denken dat de ratio ons handelen bepaalt, en dat we daarom te allen tijde eenduidige, rationele beslissingen kunnen nemen. De filosofie, zegt Otten, beschouwt de wereld, en daarmee ook het menselijk leven, als maakbaar en beheersbaar. (Ibid.:47) Deze opvatting druist in tegen Ottens opvatting over het wezen van de mens dat volgens hem door een onbegrijpelijke en ongrijpbare ziel bepaald wordt. (Ibid.) Wie meent het mysterie van de ziel te kunnen grijpen en begrijpen, loopt het risico zichzelf te verliezen:

Je kunt het kraken, maar niet krijgen. En degene die je, al krakend, werkelijk vermorzelt, dat ben je zelf. 'Het' ontsnapt, en hoe groter de rationele en materiële mensenmacht, des te onmachtiger het personage als het om willen gaat.

(Ibid.)

Otten beschouwt het idee van de vrije wil als een uitwas van het geloof in de macht van de rationaliteit. Een gevolg van ons blind vertrouwen in het rationele denken is dat we zijn vergeten dat we nooit zullen weten of we inzake euthanasie goed hebben gehandeld of niet. We kunnen nog zulke rationele argumenten bedenken voor onze beslissing om te sterven, maar uiteindelijk tasten we, zegt hij, als het om dergelijke beslissingen gaat, altijd in het duister. Als we iemand bij het sterven helpen, of als we zelf besluiten dat we niet meer verder leven willen, zullen we ten eerste nooit weten of dat besluit juist is geweest. Wie dood is, kan niet vertellen of hij of zij zich in deze toestand wel of niet gelukkig voelt. En ten tweede kunnen we over de dood niet op een zuiver rationele manier praten - wanneer we dat wel doen, gaan we voorbij aan alle niet-rationele gevoelens die de dood altijd met zich meebrengt. Juist die gevoelens maken ons menselijk: ons bestaan is niet a-priori rationeel en inzichtelijk. De traditionele filosofie ontkent deze schijnbare tegenstelling tus- 
sen het verlangen naar orde en macht en de niet-rationele werkelijkheid. Zij gaat ook woorbij aan het gevoel dat we door iets ongrijpbaars voortgedreven worden. Zo schrijft Otten:

Dat wat door velen goede, welberedeneerde keuzes worden ge* noemd, wanneer het bijwoorbeeld om de levensbeëindiging van lijdende mensen gaat, onderga ik als kiemen van tragedies. Men doet alsof imen, na ampele, rationele overwegingen, het juiste heeft gedaan, terwijl men zijn beslissing uiteindelijk niet ethisch - dat wil zeggen: niet rationeel - kan funderen. Er is altijd iets in te brengen tegen beslissingen over leven en dood, en er is nooit iets zeker, we tasten op een fatale wijze in het duister. En precies deze sensatie van duisternis, waar oplossingen geen oplossingen zijn, waar het wel lijkt alsof we uit vrije wil handelen, maar waar we in feite gedrevenen zijn - terwijl we tegelijkertijd niets liever dan instrumenten zouden zijn, uitwoerders van andermans gebalanceerde wens - precies die sensatie wordt door het verlichte, oplossingsgerichte, ingenieurlijk denken niet begrepen.

(Otten 1995C:55)

Alleen de tragedie, zegt Otten, is in staat de mens te tonen zoals die werkelijk is. De tragedie beschouwt hij als de tegenpool van de fillosofie. Waar in de filosofie het streven naar inzicht in en beheersbaarheid van mens en wereld door het verstand centraal staat, laat de tragedie zien dat dit streven weliswaar menselijk, maar futiel is. Volgens Otten maakt de tragedie duidelijk dat menselijk handelen in de meeste gevallen volslagen irrationeel en tegenstrijdig is. Dat doet de tragedie op twee niveaus: ten eerste door de inhoud van het toneelstuk of het boek (Oedipus is zelf de moordenaar die hij zoekt, Medea doodt in een vlaag van razernij haar eigen kinderen), en ten tweede door de macht die het spel op toeschouwers en lezers uitoefent. Niet alleen wekken de met dilemma's worstelende hoofdpersonen van een tragedie onze sympathie op, we laten ons ook door het spektakel in vervoering brengen. De tragedie, stelt Otten, sleept ons mee, of we het willen of niet, en lat ons daardoor zien wat we werkelijk zijn: "gedrevenen". 'We laten ons drijven, door de spanning, door de motoriek, door de voorkennis van de afloop, in een richting die alleen maar kan gaan naar een toestand waarin we, als het toneelstuk voorbij is en we tussen de toeschouwers naar huis sjokken, boven alles moeten erkennen dat ook wij gedrevenen waren. En dat we zo hebben willen zijn.'(Otten 1995b:47)

Zowel de inhoud als de vorm van een tragedie makt dus duidelijk dat het een illusie is te denken dat we in bijna alle situaties een rationele en zelfstandige beslissing nemen kunnen. De tragedie, zegt Otten, ondermijnt daarmee het geloof in de vrije wil: 
Ons sacrosancte idee van de vrije will, van het individu dat, als er maar aan fysieke en materiele voorwaarden is voldaan, in wrijheid en volle ansprakelijkheid zijn lot bepaalt, wordt door een tragedie danig op de proef gesteld. De methode van de tragedieschrijver is proefondervindelijk: hij sleeptzijn toeschouwers mee in iets wat die toeschouwer, met koel verstand, afkeurenswaardig zou vinden.

(Otten 1995d:64)

Otten ziet daarom in de discussie rond euthanasie een belangrijke taak voor de tragedieschrijver weggelegd. Als romanschrijver, zegt hij in 1995 een gesprek met het Nieuw Wereld Tijdschrift, beschouwt hij het als zijn plicht 'de ideeën over zelfbeschikking onderuit [te] halen', juist omdat ons handelen meer bepaald wordt door onze emoties dan we bereid zijn toe te geven. Rationele verklaringen maskeren dikwijls complexe gevoelens, zoals angst voor het leven:

Ik ben een rationalist in de zin dat ik niet obscuur wil zijn. Maar ik ben ook een realist. Ik wil dat de machten erkend worden die op mensen worden uitgeoefend, de krachten waardoor ze veell meer een speelbal zijn van hartstochten en passies en afgunsten. Dat heel veel van wat rationeel genoemd wordt, bijwoorbeeld een doodswens, een rationalisering is van een veel grotere en diepere angst, om te leven bijvoorbeeld.

(Blanken 1995:56)

Met andere woorden: we mogen dan wel denken dat we in alle vrijheid goed beredeneerde beslissingen nemen, in werkelijkheid laten we ons, bij alles wat we doen, onbewust en ongewild niet alleen door onze emoties, wensen en angsten leiden, maar ook door de omstandigheden en de handelingen en meningen van mensen om ons heen. Het idee dat de mens in staat is geheel vrijwillig, zelfstandig en weloverwogen over zijn eigen levenseinde na te denken en te beslissen, is een illusie. Niet de filosofie, maar de literatuur, en in het bijzonder de tragedie, toont ons dat.

\section{Zelfbeschikking versus bepaling door het lot}

'Voortdurend,' schrijft Otten in zijn essay in de bundel Als de dood voor het leven, 'draait het om de botsing tussen het verlangen van mensen om "zelf hun eigen werk te zijn", en de kracht van de "noodzakelijke machten".' (Otten 1995d:64)

De 'noodzakelijke machten' worden door Otten ook 'het lot' en 'het noodlot' genoemd. (Ibid. 44) Dat het hierbij om een macht gaat die niet menselijk is, kan uit zijn definiëring van de dood als 'het buitenmense- 
lijke" worden afgeleid. De dood, zegt hij, is iets dat ons overkomt of dat ons wordt aangedaan. Het is daarom een illusie te denken dat wij zelf over onze dood mogen beslissen. (Ibid.:69) Ook dat wordt volgens Otten inzichtelijk gemaakt door de tragedieschrijver. De schrijver weet 'dat mensen, als het erop aankomt, en ze moeten kiezen of handelen, hun eigen werk niet zijn". (lbid.)

Als de dood een buitenmenselijke aangelegenheid is, moeten we de aanspraak op een vrijwillig en weloverwogen verzoek niet alleen als een illusie beschouwen, maar ook als een bewijs van hoogmoed. 'Ik vind het liberale ballen," zegt Otten in een interview in de Volkskrant in 1995, "die steeds tegen me zeggen dat ze hun leven zelf gemaakt hebben, dat ze los staan en autarkisch zijn, ik vind het vreselijke verhallen. Het is hoogmoed. Het is de ballenkant van het liberalisme.' (Tromp 1995:1)

Ottens afkeuring beperkt zich niet tot het nemen van beslissingen ten aanzien van ons huidige leven. Otten laakt ook het idee dat wij beslissingen over de toekomst nemen kunnen. Ook dat idee, meent hij, is een uitvloeisel van het vertrouwen dat wij sinds Plato in het strikt rationele denken stellen. Ons vertrouwen in de macht van de wetten van de logica doet ons ten onrechte geloven dat wij de loop van ons leven volledig zelf bepalen. De tragedie laat echter zien dat ons leven bepaald wordt door andere, buitenmenselijke krachten. (Otten 1995d:69)

\section{Zelfbeschikking en medeplichtigheid}

Het idee van vrijwilligheid, zoals de wet dat verwoordt, suggereert dat niemand zich door de meningen, gevoelens of denkbeelden van anderen hoeft te laten beïnloeden. Maar in het echte leven is volgens Otten altijd sprake van beïnvloeding door en van anderen. Dat geldt ook voor beslissingen over de dood. Iedereen die volgens de bepalingen van de wet een onnatuurlijke dood wil sterven, is direct afhankelijk van de beslissingen van artsen en indirect van de instemming van partners en familieleden. Zelfs wanneer iemand zich zonder hulp van anderen doodt, is er geen sprake van autonomie: zelfmoordenaars zijn praktisch gezien weliswaar niet afhankelijk van de hulp of instemming van anderen, maar zij beïnvloeden met hun dood wel degelijk de levens van anderen. Zij beroven anderen van een medemens. En erger nog, zelfmoordenaars, stelt Otten, betrekken anderen, of zij het willen of niet, bij het overtreden van het taboe op moord en zelfdoding. Datzelfde geldt voor wie een arts om euthanasie vraagt. Wie van een arts verlangt dat die hem of haar bij het sterven helpt, maakt van die arts een moordenaar.

Otten verwoordt zijn opvatting over betrokkenheid en medeplichtigheid in zijn essay in Als de dood voor het leven en in een krantenartikel dat hij schreef naar aanleiding van de aangekondigde zelfdoding van de 
schrijwer Adriaan Venema in 1993. (Otten 1993a:2) Alle mensen die van Venema's plannen op de hoogte waren, schrijft hij, maakten zich schuldig aan Venema's dood. Zij deden immers niets om hem van zijn voornemen af te brengen. Afkeurenswaardiger nog vindt Otten dat de samenhang tussen Venema en zijn vrienden op rationele gronden ontkend werd. Zijn vrienden meldden dat zij hem begrepen, en dat zij hem daarom niet van zijn voornemen wilden afbrengen. Ook Venema rechtvaardigde zijn besluit met strikt rationele overwegingen. Hij wees op het recht op zelfbeschikking, en hij was ervan overtuigd dat hij door zijn dood euthanasie bespreekbaar zou maken: 'Over tien jaar, zei hij,' schrijft Otten, 'zouden we glimlachen over dit optreden van hem, want dan zou het heel gewoon zijn wanneer mensen die dood willen van hun arts de medicijnen krijgen voor een milde dood.' (Otten 1995d:55) Venema noch zijn vrienden hadden oog voor hun onderlinge verbondenheid. Venema verzocht zijn omgeving zijn besluit te respecteren, en zijn vrienden deden wat hij van hen vroeg. Dat Venema's dood de levens van anderen zou beinnvloeden, zagen ze niet. Niemand, zegt Otten, schreef: "Venema, ik besta, dus jij had ook moeten bestaan; jouw stap trekt me, als ik me er niet uit alle macht tegen verzet, met je mee.' (Otten 1993a:2)

Venema"s vrienden en ook Venema zelf waren volgens Otten uiteindelijk even hoogmoedig als een arts die euthanasie toepast en zich daarmee met een 'buitenmenselijke aangelegenheid' inlaat. Ze ontkenden hun verbondenheid met elkaar, ze beseften niet dat ze in een tragedie meegesleurd werden, en ze begrepen evenmin dat ze hun vriend met al hun begrip in de steek lieten. Volgens Otten hadden Venema's vrienden zich door hun gevoel moeten laten leiden. Venema op zijn beurt had zijn vrienden niet om begrip mogen vragen. 'Begrip,' concludeert Otten, 'kan dodelijker zijn dan welke reden om dood te willen gaan ook.' (Ibid.) Maar medeplichtigheid manifesteert zich volgens Otten niet alleen bij euthanasie of zelfdoding. Het simpele feit dat iedere stervende levenden achterlaat, maakt de levenden schuldig. Otten citeert in dit verband de schrijwer Elias Canetti: 'Hij schreef: we zijn allemaal overlevenden. Als iemand sterft, overleef jij.' (Tromp 1995:2)

De dood van een mens staat volgens Otten nooit los van het leven van anderen. Het idee van een zelfstandige en vrijwillige beslissing om te sterven heeft niets te maken met de werkelijkheid.

\section{Slotsom}

De wet op euthanasie verlangt volgens hoofdstuk II artikel 2, lid 1a, dat een arts 'de overtuiging heeft gekregen dat er sprake was van een vrijwillig en weloverwogen verzoek van de patiënt'. Achter deze eis gaat de gedachte schuil dat mensen autonoom zijn en over hun eigen lot kunnen 
en mogen beschikken. Otten weert zich tegen deze aanname. Volgens hem lijkt het alleen maar alsof de mens over zijn lot beschikken kan. Dat betekent nog niet dat de mens dat mag. Het idee van de autonome, strikt rationeel denkende en handelende mens is, zegt hij, ingevoerd door de westerse filosofie, die op strikt rationele wijze opereert. Dit staat in contrast met de werkelijkheid, die allesbehalve rationeel is: leven en dood, stelt Otten, worden in hoge mate door emoties bepaald. We mogen niet vergeten dat wij de menselijke ziel niet kunnen kennen. Bovendien is de mens niet autonoom. Leven en dood worden bepald door het 'buitenmenselijke', het lot. De dood van een mens beïnvloedt altijd het leven van anderen. Alleen de tragedieschrijver, die oog heeft voor de irrationaliteit van het menselijk leven, onze afhankelijkheid van het lot en van andere mensen, is in staat de complexiteit van leven en dood te vatten. De tragedie doet ons door haar inhoud en vorm beseffen dat we allerminst vrijwillig en rationeel handelen. De filosofie, die ervan uitgaat dat de mens autonoom is en daarom in staat is onafhankelijk van anderen strikt rationele beslissingen te nemen, stelt zich boven de werkelijkheid, en maakt zich schuldig aan hoogmoed. De wet die bepaalt dat euthanasie en hulp bij zelfdoding geoorloofd zijn indien een patiënt daar vrijwillig en weloverwogen om verzocht heeft, is een uitvloeisel van deze hoogmoed.

\section{Uitzichtloos en ondraaglijk lijden}

Artsen die levensbeëindiging op verzoek toepassen of hulp bij zelfdoding verlenen, worden van straffen uitgesloten, zegt de wet op euthanasie, als er sprake is van 'uitzichtloos en ondraaglijk lijden van de patiënt'. (Hoofdstuk II, artikel 2, lid Ib) Het zal geen verwondering wekken dat Otten kritiek heeft op het idee dat het menselijk lijden meetbaar is. Een van zijn grootste bezwaren tegen de legalisering van euthanasie en hulp bij zelfdoding betreft immers de rationalisering van ziekte en dood. Die rationalisering komt ook tot uitdrukking in de veronderstelling dat er zoiets als een aanwijsbaar 'juist' moment om te sterven bestaat. Ook het idee dat de toestand van een zieke zich adequaat laat uitdrukken door een abstract begrip als 'ondraaglijk lijden', is Otten een doorn in het oog. Het gebruik van de begrippen 'uitzichtloos' en 'ondraaglijk' suggereert immers dat lijden niet alleen meetbaar is, maar ook beheersbaar en daardoor in principe oplosbaar. Dat doet, meent hij, vermoeden dat we op inzichtelijke en ondubbelzinnige wijze niet alleen kunnen bepalen wat ondraaglijk lijden is, maar ook wanneer het punt gekomen is waarop het leven van een zieke zodanig ingeboet heeft aan kwaliteit, dat sterven 
voor hem of haar wenselijker is dan verder leven. De dood wordt op dat moment niet langer gezien als verlossing, maar als plicht. Rationalisatie van de doodsstrijd, zegt hij in een interview met de Volkskrant in 1995 , leidt tot de overtuiging dat er zo gauw mogelijk een einde aan elk ondraaglijk lijden gemaakt moet worden. (Tromp 1995:1-2)

Het idee van het meetbare lijden heeft voor Otten onaanvaardbare consequenties. Ten eerste wijst hij op de problemen die dit idee met zich meebrengt, zoals het bepalen van criteria en het vaststellen van eenduidige, exacte begrippen. Ten tweede stelt hij dat lijden een zaalk is van meer dan één persoon. Wanneer er een einde aan een lijden gemaakt wordt, heeft dat gevolgen voor ten minste twee personen: voor degene die sterft én voor degene die de patiënt bij het sterven helpt. Die verstrengeling zegt niet alleen iets over de essentie van het menselijk leven, het maakt het ook moeilijk vast te stellen wanneer we van ondraaglijk lijden mogen spreken. Volgens Otten is het dikwijls de vraag wie er precies lijdt: de patiënt, of zijn of haar omgeving. Daarom is het onduidelijk wie bepaalt of en wanneer het lijden van een patiënt ondraaglijk geworden is: de arts, de patiënt, of de partner, vrienden of familieleden van de patiënt. (Otten 1995d:61)

Ten slotte stelt Otten dat het idee van ondraaglijk lijden als een oplosbaar probleem tot een verarming of zelfs ontmenselijking tot gevolg heeft. Lijden, en zelfs ondraaglijk lijden, zegt hij, maakt onmiskenbaar deel uit van het menselijk bestaan. Lijden geeft het leven een bepaalde zin. Dat te ontkennen, voert tot een ontkenning van 'het tragische, dat aan ieder leven kleeft'. (Otten 1994b:2)

\section{De grens van het draaglijke}

In 'De allereerste zendgemachtigde Euthanasist', een artikel dat hij in 1994. schreef naar aanleiding van de IKON-documentaire 'Dood op verzoek', gaat Otten in op het begrip 'uitzichtloos en ondraaglijk lijden'. Wanneer, vraagt hij zich af, gaat lijden over in zinloos en ondraaglijk lijden? Waar ligt de grens van het draaglijke? En wanneer rechtvaardigt die grens het doden van een patiënt? Als een arts een patiënt met een ongeneeslijke ziekte niet wil laten lijden, polemiseert hij, zou het dan niet beter zijn de patiënt 'die te horen krijgt dat hij nog maar enkele maanden heeft te leven, meteen de dood te laten vinden? Besparen we de patiënt daar niet een berg zinloos lijden mee?' (Otten 1994b:2)

In het geval van Cees van Wendel de Joode, wiens euthanasie door zijn huisarts Wilfred van Oijen onderwerp van de documentaire was, leek geen sprake te zijn van een ondubbelzinnig moment waarop het lijden overging in ondraaglijk lijden. Sterker nog, Van Wendel de Joode leek volgens Otten meer aan het leven te hangen narmate het lijden ver- 
ergerde. In zijn dagboek noteerde hij, schrijft Otten, dat hij 'de grens steeds verlegde'. (Ibid.) Otten suggereert dat de voortdurende aanwezigheid van de cameraploeg Van Wendel de joode in staat stelde zijn lichamelijk lijden beter te verdragen: de grote hoeveelheid aandacht die hij ontving, maakte zijn lijden draaglijker. ${ }^{26}$

Anders dan de pleitbezorgers van euthanasie ons willen doen geloven, concludeert Otten in zijn artikel over deze documentaire, voert lijden niet automatisch tot de wens zo spoedig mogelijk te sterven, zelfs al heeft de patiënt kenbaar gemaakt dat hij of zij naar de dood verlangt. Het was duidelijk, zegt hij, dat Van Wendel de Joode weliswaar verklaarde dat hij wilde sterven, maar dat dat niet waar was. Anders gezegd: vanuit een zuiver rationeel standpunt beschouwd, vond Van Wendel de Joode, net als zijn vrouw en zijn arts, dat er een einde moest komen aan zijn (Wendel de Joodes) leven. Volgens Otten was dat echter niet wat Van Wendel de Joode wilde. "Het enige dat werkelijk aangrijpend en vreemd genoeg vitaal in de film was,' schrijft hij over Dood op verzoek, 'dat was Cees' woedende huilbui over zijn naderende dood. Hij wilde niet dood.' (Ibid., cursivering in origineel)

Al eerder wees Otten op de onmogelijkheid van een objectieve bepaling van de grens van het draaglijke. Op 19 november 1993 verscheen in NRC Handelsblad een artikel dat hij schreef naar aanleiding van de VPROdocumentaire 'Lopende zaken' die op 14 november van dat jaar uitgezonden werd. De documentaire gaat over een echtpaar waarvan de vrouw dementeert. De programmamakers, zegt Otten, pretendeerden het ondraaglijk lijden van de vrouw te tonen. Maar wat ze werkelijk lieten zien, was het onbehagen van haar echtgenoot. Die was ervan overtuigd dat het leven van zijn vrouw voor haar geen zin meer had. In werkelijkheid had haar leven voor hém geen zin meer. De echtgenoot had zich, zegt Otten, laten leiden door het maxime 'beter dood dan zo', waarbij het 'zo' vooral betrekking had op zijn interpretatie van de toestand van de vrouw. Dit maxime is volgens Otten een gevolg van een uitspraak van Huib Drion, oud-woorzitter van de Hoge Raad, die in 1991 stelde dat iedereen die dat wil de middelen moet krijgen om een einde te maken aan zijn of haar leven. Dankzij de discussie over "de pil van Drion", meent Otten, lijkt het alsof we niet alleen een ondubbelzinnige definitie van ondraaglijk lijden. kunnen geven, maar ook over een ondubbelzinnige, strikt rationele oplossing beschikken. ${ }^{27}$ 'Omdat Drions pil tot de uitvoerbare, bespreekbare mogelijkheden is gaan behoren,' schrijft hij, 'wordt het steeds moeilijker om niet te denken "beter dood dan zo". Het noemen alleen al van de Pil makte het deze filmmakers moeilijk om iets anders te filmen dan datgene dat de Pil, als oplossing, mogelijk en zelfs noodzakelijk maakt.' (Otten 1993b:2) 
In het geval van de dementerende vrouw stelde niet de zieke de grenzen van het draaglijke vast, maar werden ze haar van buitenaf opgelegd. Dat laatste was niet alleen de schuld van de echtgenoot van de patiënt, die het duidelijk moeilijk vond om met een demente vrouw te leven, en meer leek te lijden dan zijzelf. Ook de makers van de documentaire, schrijft Otten, waren 'in de klem gaan staan die ze zelf, door Drion zo pontificaal te citeren, hadden neergelegd'. (Ibid.)

De programmamakers waren in nog een andere val getrapt. Ze leken de werkelijkheid te registreren, maar filmden alleen dat wat in het clichébeeld van ondraaglijk lijden past. Volgens Otten gebeurde dit met opzet, opdat de kijkers niet zouden denken dat het onmogelijk is een eenduidige definitie van uitzichtloos lijden te geven. Zouden we beseffen dat er geen definitie van het begrip bestaat, dan zou het een stuk moeilijker worden te beslissen wanneer we kunnen overgaan tot euthanasie of hulp bij zelfdoding. "Want iedere glimp van iets anders dan uitzichtloosheid zou ons hebben doen afvragen wat "beter dood dan zo" nu eigenlijk inhoudt," schrijft Otten. Zouden de filmmakers momenten hebben laten zien die allesbehalve ondraaglijk waren, 'dan zouden we hebben gedacht, tegen een soort desperaat beter weten in: als dit kan, wat kan er dan nog meer? We zouden werkelijk in verwarring zijn geraakt en onszelf hebben gevraagd wanneer we het woord "uitzichtloos" nu eigenlijk moeten gebruiken.' (Ibid.)

In het geval van dementie projecteren we, aldus Otten, al te gauw onze eigen angsten voor verlies aan decorum of karakterverandering op de patiënt en noemen we een toestand ondraaglijk die dat in werkelijkheid misschien niet is. Misschien kon de dementerende vrouw nog genieten van bijvoorbeeld het uitzicht op een boom. 'En gesteld dat we de vrouw,' schrijft Otten, 'in een opname die naar valt te vrezen niet eens in het hoofd van de makers is opgekomen, hadden kunnen zien kijken naar, zeg een boom wuivend in de wind - dan zouden we, wie weet, gedacht hebben: ze vindt het prettig om te kijken naar een boom wuivend in de wind.' (IIbid.)

Otten beschouwt de term 'ondraaglijk lijden', zo mogen we concluderen, als een relatief begrip. Ten eerste is volgens hem in veel gevallen niet vast te stellen wanneer het lijden ondraaglijk geworden is. Het voorstel van Drion om de verkoop van zelfdodingmiddelen te legaliseren, heeft ertoe geleid dat veel mensen menen dat er een duidelijke lijdensgrens bestaat, en dat die grens al vastgesteld kan en moet worden zolang er nog geen sprake is van echt lijden. Ten tweede leidt ondraaglijk lijden, meent hij, niet automatisch tot een absoluut en constant verlangen naar de dood. Bovendien is niet altijd duidelijk wie er lijdt, de patiënt of zijn of haar omgeving. En ten slotte neigen we ertoe te denken dat mensen die 
volgens de medische maatstaven ondraaglijk lijden, op geen enkele manier meer van het leven kunnen genieten.

\section{De taboeitsering van het lijden}

De legalisering van euthanasie en hulp bij zelfdoding, maar vooral de dreigende invoering en legalisering van 'de pil van Drion' brengen volgens Otten het gevaar van de taboeisering van het lijden met zich mee. ${ }^{28}$

In zijn eerder genoemde artikel over de documentaire Lopende zaken verwoordt Otten zijn angst voor de taboeissering van het lijden als volgt:

Te vermoeden valt dat Drions pil een hele uitkomst is - vooral voor jezelf als je zelf midden in je leven bent en op de televisie naar mensen kijkt die niet worden betrapt op enigerlei aanraking, die door degenen die met hun camera naar haar staren niet naar buiten de wind in worden genomen, of door kinderen of vrienden worden omarmd. Zulke sentimentaliteiten, ze worden overbodig als ik me, dankzij de Pil, steeds vanzelfsprekender af zal vragen: waar halen ze het recht vandzan om er nog te zijn?

(Otten 1993b:2)

In zijn afkeer van wat Otten in navolging van I. van der Sluis en C.I. Dessaur het 'euthanasiasme" noemt - dat wil zeggen, een al te grote bereidheid om de legalisering van euthanasie en hulp bij zelfdoding te accepteren-, gaat hij zo ver dat hij de pleidooien voor de legalisering van euthanasie vergelijkt met naziargumenten ter verdediging van de moord op ongeneeslijk zieken.

In juli 1993 constateerde W.C.M. Klijn, hoogleraar medische ethiek in Nijmegen, in een artikel in het dagblad Trouw 'een treffende gelijkenis' tussen de Nederlandse euthanasiewetgeving en de nationaal-socialistische opvattingen over euthanasie. Ter illustratie van zijn uitspraak verwees hij naar de film 'Ich klage an', een propagandafilm die regisseur Wolfgang Liebeneiner in 1941 in opdracht van Joseph Goebbels maakte. De film, die in 1994 in het Filmmuseum in Amsterdam vertoond werd, is gebaseerd op de roman Sendung und Gewissen van de Duitse auteur Hellmuth Unger (1891-1953). Een van de hoofdpersonen, de vrouw van een arts, lijdt aan multiple sclerose. Wanneer ze bijna helemaal verlamd is, dient haar man haar op haar verzoek een dodelijke dosis medicijnen toe. De man wordt aangeklaagd, maar weigert zich te verdedigen. Als hij dankzij een vriend en collega van moord vrijgesproken wordt, klaagt hij op zijn beurt de wet aan 'die artsen en rechters verhindert om zich te kwijten van hun taak het volk te dienen'. (Klijn 1993) De vriend, die aanvankelijk tegen euthanasie was, verandert van mening als een door hem 
behandeld kind door de complicaties van een hersenvliesontsteking het verstandelijk vermogen verliest.

De film, vertelt Otten in het eerder genoemde interview met de Volkskrant, maakt duidelijk hoe het rationele denken over het levenseinde tot een taboe op het lijden kan voeren. Dit taboe leidt er op zijn beurt toe dat iedere ongeneeslijk verklaarde zieke moreel en intellectueel ver plicht is een einde aan zijn of haar leven te maken of te laten maken:

Het was een heel mooie film, vreselijk goed gemaakt. Hij ging over een stervende aan MS. Het was wat je noemt een integere film, hij bevatte alle argumenten pro euthanasie die je nu ook hoort, hij had zó door de vereniging voor vrijwillige euthanasie geproduceerd kunnen zijn. [...] Wat zo goed was aan de film was dat hij toonde waartoe rationalisatie van de doodsstrijd kan leiden. Namelijk dat het móét, dat het mooi genoeg is geweest met het leven, dat het goed is, dat wie niet wil, achterlijk is.

(Tromp 1995:2)

Sterker nog: euthanasie wordt in de film voorgesteld als een handeling uit liefde, een weldadige en vooral moedige, mannelijke daad:

Haar echtgenoot, die in voorafgaande scènes een heroîsche, maar vergeefse poging heeft gedaan het anti-serum te vinden, is nu mannelijk en vastberaden. Zijn vriend, de weigerachtige arts, speelt beneden piano, en het is duidelijk: die is laf. Zonder handenwringen overhandigt de echtgenoot het flesje Zachte Dood. Lippen die het drankje totzich nemen. Meanderende, maar onomkeerbaar aanzwellende pianomuziek. Two-shot van de echtelieden die om beurten 'ich liebe dich' fluisteren. Hij houdt echt van haar, dat weet zij nu, want hij heeft het laatste medicijn verstrekt.

(Otten 1994a:2)

De film heeft, zegt Otten, een voordeel: hij theoretiseert niet over de voor- en nadelen van euthanasie, maar hij toont hoe een arts een einde maakt aan het leven van een patiënt. De film laat niet alleen zien hoe makkelijk het is een ander te laten sterven, maar ook wat er gebeurt als je iemand bij het sterven helpt. "Je kunt nog zoveel argumenten pro of contra levensbeëindiging door artsen aanvoeren, het blijft allemaal theorie zollang je je niet voor wilt stellen, zo precies en gedetailleerd mogelijk, hoe het voor één iemand mogelijk is om een ander hoogstpersoonlijk een spuitje te geven.' (Ibid.)

Aan die wil, meent Otten, ontbreekt het blijkbaar veel mensen. Hun 
idee van euthanasie blifft abstract. Ze doen uitspraken over situaties waarvan ze zich nauwelijks een concrete voorstelling willen of kunnen maken. Hun uitspraken over euthanasie blijven idealistisch, in de letterlijke betekenis van het woord. Zoals dat in de volgende, in 1994 door Otten opgetekende televisieopname, gebeurt:

Enige tijd geleden was de actrice Mary Dresselhuys bij Karel van der Graaf en zij mocht zeggen wanneer zij dood wilde. [...] Mary Dresselhuys zei: "bijwoorbeeld als ik allebei mijn benen kwijt ben.' Karel keek de dokter aan die ook aan tafel zat, en die dokter zei: "dan ben ik blij, mevrouw Dresselhuys, dat u mijn patiënt niet bent.'

(Ibid.)

Maar ook de sterfscène in "Ich klage an' is volgens Otten geidealiseerd. "Wat we te zien krijgen is een dood zoals gezonde mensen willen dat hij georganiseerd is - een verheerlijking van de laatste ademtocht. Een goed gespeeld, mooi uitgelicht toneelstuk.' (Ibid.) De film is een idealisering en een verheerlijking wan de zachte dood. Hij voert, zegt Otten, 'de pleger van de euthanasie op als een held, en het sterven als zingeving". (Ibid.)

De film laat niet de twijfels, de angsten en het leven tussen hoop en vrees zien. Daarom, meent Otten, is 'Ich klage an' een film die ook bij onze tijd past. De film sluit aan bij onze drang de werkelijkheid te verdringen, en onze ogen te sluiten voor dat wat de dood werkelijk betekent: niet een zacht wegglijden van de zieke in het niets, maar een moeizaam en onaangenaam proces dat niet alleen invloed heeft op de zieke, maar ook op zijn of haar omgeving:

Het is in onze gezondheidscultuur prettiger om na te denken over zelfbeschikking en beschikking over levens, dan over verpleging en verzorging. Het stat ons beter om de dood zacht te noemen, dan om te erkennen dat hij de hardste test is, van de zieke en van de laatste verzorgers.

(Ibid.)

Mensen die euthanasie beschouwen als een makkelijke en aangename oplossing, zegt Otten, nemen hun toevlucht tot het zuiver rationele denken. Zolang we vasthouden aan het abstracte idee van een probleemloze en probleemoplossende zachte dood, dreigt het gevaar dat alle ongeneeslijk zieken zich gedwongen voelen een einde aan hun leven te laten maken. Het taboe op het doden van een mens heeft op die manier plaats gemaakt voor het taboe op het lijden. 
Het taboe op het lijden maakt volgens Otten iedereen die met lijden geconfronteerd wordt, tot een potentiële moordenaar. Volgens het nieuwe taboe, zegt hij, moet nu eenmaal aan elk lijden een einde gemaakt worden. Wij moeten ons daarom voortaan niet alleen als potentiële slachtoffers van euthanasie, maar ook als potentiële moordenaars zien: 'Toen een paar jaar later de euthanasiediscussie losbarstte, besefte ik dat er inderdaad in de wereld van 1989 iets veranderd is. Het voldoet niet langer meer jezelf voor te stellen als het potentiële slachtoffer van een eventuele tegenstander.' (Otten 1996:21)

Met onze rationele instelling gaan we er te makkelijk van uit dat het potentiële daderschap geen enkel probleem oplevert - de betrokkenheid bij euthanasie of hulp bij zelfdoding wordt immers door de wet gesanctioneerd. Maar het is een illusie, stelt Otten, te denken dat de wet automatisch een einde maakt aan alle gevoelens als schuld, twijfel en spijt. Omdat noch de wet, noch de strikt rationele discussie ons enig inzicht biedt in potentiële emotionele reacties, stelt hij voor niet alleen de klassieke tragedies, maar ook de bijbel te raadplegen. Alleen de tragici en 'degenen die de oudtestamentische verhalen noteerden' maken duidelijk dat het zondebesef, net als het lijden, een fundamenteel menselijke eigenschap is, die zich niet weg laat redeneren, en die zich ook niet rationeel laat begrijpen. Ze laten zien dat het onze plicht is te zorgen voor mensen die lijden. Wanneer we die plicht niet op ons nemen, maken we ons schuldig aan onmenselijk gedrag, en zullen we door schuldgevoelens gekweld worden. (Ibid.)

\section{Lijden als intermenselijke aangelegenheid}

In de vorige paragrafen is meerdere malen aan de orde gekomen dat Otten de voorstanders van legalisering van euthanasie en hulp bij zelfdoding verwijt dat ze vergeten dat lijden nooit de angelegenheid van alleen de patiënt is. Otten hecht groot belang aan de betrokkenheid van de naasten van patiënten, en de ambigue betekenis die het lijden van de zieke ook voor hén heeft. Volgens Otten is het lijden van een patiënt vaak verrijkend voor zijn of haar omgeving. Zo schrijft hij in een artikel getiteld "Over de erfzonde":

ledereen die bij een sterfbed heeft helpen zorgen herinnert zich de ogenblikken warop hij hoopte dat het allemaal afgelopen zou zijn: waarop hij plotseling begon te verlangen naar een kussen om alle ellende te smoren; en toch herinneren velen zich ook hoe deze ogenblikken werden afgewisseld door perioden waarin er weer gelachen werd, of gesproken. En achteraf blijkt niets zo veelbetekenend te zijn geweest als zo'n wak in het lijden.

(Otten 1996:21) 
Lijden is volgens Otten niet zinloos, zelfs miet als het uitzichtloos is. De meeste mensen, zegt hij in het interview in de Volkskrant, beschouwen het lijden als een abnormaliteit, als iets dat niet tot het normale, menselijke leven hoort.

Maar lijden is allesbehalve abnormaal of zinloos. Lijden bereidt niet alleen de zieke, maar ook zijn of haar omgeving voor op de dood. In die zin hoort het lijden bij het leven. Lijden, stelt Otten, kan het leven, anders dan de voorstanders van de legalisering van euthanasie menen, zelfs een nieuwe betekenis geven. Zo zegt hij in hetzelfde vraggesprek: 'tk heb een vriend. Het einde is bij hem ingezet. Hij zal niet meer genezen, al kan het nog jaren duren. Hij lijdt. Is zijn bestaan daarmee zinloos geworden? lk vind zijn leven in ieder geval fascinerender.' (Tromp 1995:2) Legalisering van euthanasie voert volgens Otten tot ontkenning van het belang van het lijden voor iedereen, zieken en niet zieken.

\section{Lijden als 'tragisch'}

In zijn kritiek op de euthanasiediscussie en de legalisering van euthanasie brengt Otten telkens weer de overtuiging tot uitdrukking dat het onmogelijk is in abstracte of strikt rationele begrippen over lijden en sterven te spreken. De dood, stelt hij, is een mysterie, en lijden is niet iets dat we op enig punt zonder enige twijfel als ondraaglijk kunnen classificeren, opdat aan dat lijden zonder problemen een einde gemaakt kan worden.

Gezonde mensen gaan er volgens Otten te makkelijk van uit dat ondraaglijk lijden automatisch tot het verlangen naar de dood voert. Dat hun opvatting een misvatting is, blijkt uit het gegeven dat veel ongeneeslijk zieken zich, net als Van Wendel de Joode, in het zicht van de dood aan het leven vastklampen: 'De doodswens is dan niet langer een abstractie [...], maar iets dat het gevolg is van acuut lijden. Niet zelden klampt een patiënt zich dan weer aan het leven vast op een manier die hij, toen hij gezond was, niet voor mogelijk had gehouden.' (Otten 1994a:2)

Het is, benadrukt Otten, niet te voorspellen hoe we reageren als we werkelijk ziek of gehandicapt zijn. Lijden is daarom niet iets dat zich laat vangen in de abstracte beschrijving van een wet, noch in het 'rationele, hygiënische codicil, dat zoveel helderder taal spreekt, dat helemaal niet worstelt, en dat, even bondig als een doodsvonnis, precies dát verwoordt wat je omstanders, die immers niets mankeren, en die ook hun codicillen zo proper hebben ingevuld, nu denken: als ik zó verlamd was, dan hoefde het van mij niet meer'. (Otten 1995b:46, cursivering in origineel) Otten waarschuwt dat het algemene gebruik van een codicil ertoe voert dat we lijden als onaanvaardbaar of onmenselijk gaan beschouwen. Zoals veel vrouwen volgens hem in de jaren zestig en zeventig te vlug abortus 
hebben laten plegen, en daarmee een beslissing genomen hebben die uit de aard der zaak nooit meer teruggedraaid kan worden, zo wordt in veel gevallen op ondoordachte wijze tot het beëindigen van een leven besloten. Hij noemt dergelijke beslissingen tragisch: " $\mathrm{k}$ heb net iets te veel verdriet gezien bij vriendinnen van mijn leeftijd die twintig jaar geleden een abortus ondergingen en nu geen kinderen hebben. Indertijd is een beslissing genomen, twintig jaar vreet het door en nu komt de machteloosheid naar boven. Het is de essentie van de tragedie.' (Tromp 1995:2)

Wat hij met 'de essentie van de tragedie" bedoelt, verheldert Otten in zijn SLAA-lezing over euthanasie. Tragisch, zegt hij daar, is als lemand een beslissing neemt die begrijpelijk is, maar ontoelaatbaar. Als er iets gebeurt dat hij omschrijft als 'dit mag niet en bestat toch'. (Otten 1995b:47)

De tragedie geeft de toeschouwer of de lezer een tragisch besef. Dit "tragisch besef" ontstaat ook na het beëindigen van wat in de wet ondraaglijk lijden genoemd wordt. In een abstracte, al te rationele discussie gaat dit besef verloren. Alleen een tragedie doet recht aan de vele, in onze ogen dikwijls irrationele aspecten van het lijden. Alleen de tragedie laat zien dat mensen die nooit meer gezond zullen worden, desondanks aan het leven hangen, en ze laat zien dat een strikt rationele beslissing om abortus te laten plegen tot onverklaarbaar verdriet leiden kan. De tragedie makt duidelijk dat de waarde van het menselijk leven juist in dergelijke paradoxale gevoelens en reacties ligt.

\section{Slotsom}

De tweede zorgvuldigheidseis heeft betrekking op het lijden. Artsen die euthanasie hebben toegepast, worden niet vervolgd wanneer zij de overtuiging hadden dat hun patiënt uitzichtloos en ondraaglijk leed. Het geloof in de almacht van de rationaliteit doet ons volgens Otten denken dat lijden niet tot het leven behoort, en daarom meetbaar en beheersbaar is. De meeste mensen beschouwen het lijden als iets waraan we zo snel en zo efficiënt mogelijk een einde moeten maken. Het gevolg is dat ongeneeslijk zieken het welhaast als hun plicht beschouwen te sterven zodra een arts heeft vastgesteld dat hun lijden aantoonbaar 'uitzichtloos en ondraaglijk' geworden is. Bovendien menen gezonde mensen al op voorhand te kunnen weten dat en wanneer ze euthanasie laten plegen. Er zijn immers criteria vastgelegd waarmee ze kunnen vaststellen wanneer euthanasie wettelijk geoorloofd is. Ook de samenhang van mensen onderling speelt een rol bij het bepalen of iemands lijden uitzichtloos en ondraaglijk geworden is. In sommige gevallen, stelt Otten, bepaalt de familie van een patiënt dat. In die gevallen is niet altijd duidelijk wie er lijdt, de patiënt of de mensen in zijn of haar omgeving. 
Otten argumenteert dat 'uitzichtloos en ondraaglijk lijden' een relatief begrip is. De mate van het lijden, of beter, de draaglijkheid ervan, is afhankelijk van de situatie waarin een patient zich bevindt. Verandert die situatie, dan verandert ook de mate van draaglijkheid van het lijden.

De opvatting dat lijden meetbaar is, heeft er volgens Otten toe geleid dat we het lijden taboeiseren. Wie volgens algemene maatstaven lijdt, is welhaast verplicht een einde aan zijn of haar leven te maken of te laten maken. Overeenkomstig die opvatting menen de meeste mensen uitspraken over eventueel toekomstig lijden te kunnen doen.

Bovendien stelt Otten vast dat het idee dat ondraaglijk lijden een reden voor euthanasie is, het leven verarmt. Lijden, zegt hij, is een wezenlijk onderdeel van de tragiek van her bestaan. De uitdrukking "uitzichtloos en ondraaglijk lijden' lijkt te veronderstellen dat lijden het leven zinloos maakt. Volgens Otten heeft lijden altijd zin, omdat het onlosmakelijk met het leven verbonden is. Het doet ons beseffen dat het leven door tegenstrijdige en ambivalente emoties bepaald wordt. Lijden, zegt hij, makt het leven van een patiënt fascinerend. De notie dat lijden meetbaar is, en het idee dat ondraaglijk lijden een reden is om een einde aan het leven van een zieke te maken, zijn het bewijs dat in de euthanasiediscussie het zuiver abstracte denken het gewonnen heeft van de dagelijkse ervaring. Daardoor vergeten we dat het leven altijd uit tegengestelde gevoelens bestaat.

\section{$4 \quad$ Overleg en consultatie}

Onder de punten c, d en e van het eerste deel van de zorgvuldigheidseisen wordt gesteld dat er in het geval van een verzoek tot euthanasie of hulp bij zelfdoding overlegd moet worden tussen arts en patiënt en tussen artsen onderling. Ten eerste moet de arts de patiënt hebben voorgelicht over "de situatie waarin deze zich bevond en over diens vooruitzichten' (punt c). De arts moet met de patiënt tot de overtuiging zijn gekomen 'dat er voor de situatie waarin deze zich bevond geen redelijke andere oplossing was' (punt d). Ten tweede moet de arts ten minste één andere, onafhankelijke arts hebben geraadpleegd, die 'de patiënt heeft gezien en schriftelijk zijn oordeel heeft gegeven over de zorgvuldigheidseisen [...]'(punt e). In de zorgvuldigheidseisen van de wet op euthanasie gaat het dus om twee soorten consultatie: tussen arts en patiënt, en tussen artsen onderling.

Afgaande op Ottens kritiek op het spreken over de dood, kan consultatie tussen artsen onderling en tussen patiënten en artsen slechts tot allerlei misstanden voeren: consultatie leidt tot machtsmisbruik, doet 
ons ten onrechte denken dat we in alle redelijkheid over dood en leven kunnen praten, en maakt artsen en patiënten medeplichtig zan overtreding van het taboe op moord.

\section{Machtsmisbruik}

De regels over consultatie zijn opgesteld om patiënten te beschermen tegen de willekeur of het machtsmisbruik van artsen. Overleg moet voorkomen dat artsen op eigen houtje beslissingen nemen over de levens van hun patiënten. Otten meent echter dat gesprekken over euthanasie artsen meer macht geven in plaats van minder. Ook als we buiten beschouwing laten dat een behandelende arts een bepaalde macht heeft doordat hij of zij de gesprekken over de vooruitzichten van de patiënt leidt, over het al dan niet geven van relevante informatie beslist en een collega consulteert zonder dat de patiënt daarbij aanwezig is, legt het onderwerp van die gesprekken hem of haar een macht in handen die volgens Otten te groot voor mensen is: hij of zij wordt gedwongen over het leven van een medemens te wikken en te beslissen. De arts krijgt de macht om met anderen te bepalen of en hoe een patiënt zal sterven.

De mens, zegt Otten, kan niet omgaan met die macht. Ten eerste is de dood een buitenmenselijke aangelegenheid. En ten tweede lijkt iedereen die de macht over het leven van een ander krijgt toebedeeld, die macht ook te willen gebruiken. Het gevolg is dat artsen zich keer op keer inlaten met zaken die hun zaken niet zijn. (Otten 1995d:58)

Om te laten zien waartoe dit machtsmisbruik kan voeren, verwijst Otten naar het in 1993 door de NCRV uitgezonden televisieprogramma 'Op leven en dood'. In dit programma werden twee doodzieke patiënten voorgesteld, die een dure behandeling moesten ondergaan om beter te worden. Een panel van niet-deskundigen mocht beslissen welke patiënt medische verzorging zou krijgen en welke niet. Het ging hier dan wel om een spel - de patiënten waren echt, maar hadden beiden reeds medische zorg ontvangen - maar juist dat spel, zegt Otten, liet zien hoe moeilijk het is met macht om te gaan. Iedereen die aan het spel meedeed, wilde ook werkelijk beschikken over het lot van de patiënten, of hij of zij verstand van zaken had of niet:

ledereen die macht krijgt toebedeeld, zelfs al is het maar in een spelletje, lijkt die macht ook te willen gebruiken. Er was niemand in de studio die niet op de knop drukte; niemand die niet, desgevraagd, een stemverklaring wilde afleggen, niemand die zei: maar dit kan niet, het is niet aan mij om hier te doen alsof ik beschikken kan.

(Ibid.) 
Macht is gevaarlijk in de handen van mensen. We kunnen de ons toegewezen macht niet of nauwelijks afwijzen, en we zijn ervan overtuigd dat de beslissingen die we vanuit een machtspositie namen, altijd op standvastige en rationele wijze gemaakt zijn. Maar zodra we over leven en dood geoordeeld hebben, weten we ons meestal geen raad met de verantwoordelijkheid die we op ons genomen hebben. We zijn veel minder rationeel dan we denken.

Ook als het om macht gaat, zegt Otten, houdt de tragedie ons een spiegel voor. De tragedie laat zien dat het buiten onze macht ligt om zonder enige twijfel en wroeging te beslissen over leven en dood. Op het moment dat een personage in een tragedie een belangrijk besluit moet nemen, voelt het zich verscheurd door tegenstrijdige gevoelens. Wie het bevel krijgt een ander te doden, wordt heen en weer geslingerd tussen 'rede en taboe, beheersing en hartstocht, goddelijke oekazes en menselijke verordeningen [...]'. (Otten 1995d:64) 'In de meeste tragedies," schrijft Otten, 'zijn mensen, zodra ze voor hun laatste dilemma's worden geplaatst, oneindig veel minder autonoom dan wij, in onze maakbare samenleving waar alles om zelfbeschikking lijkt te gaan, geneigd zijn te denken. En juist de personages met de grootste macht (Oidipoes, Agamemnon, Kreon, ze beschikken vrijwel over almacht) komen in een verhaal terecht waar zij stapsgewijs van hun zeggenschap over zichzelf en hun leven worden beroofd.' (Ibid.)

Eenzelfde verscheurdheid staat volgens Otten degene te wachten die samen met anderen de dood van een ander bepaalt. Want ondanks ons geloof in de vrije will, in de autonomie en de heerschappij van het rationele denken; ondanks ons technisch kunnen en ondanks alle wetten en bepalingen, is degene die euthanasie uitvoert, een tragisch personage: hij of zij heeft iets gedaan dat, hoewel het begrijpelijk is, eigenlijk niet mag. Dat blijkt daaruit, zegt Otten, dat artsen niet graag erkennen dat ze macht hebben uitgeoefend en over het leven van een ander beslist hebben. $\mathrm{Ze}$ maskeren hun machtsmisbruik met een beroep op hun machteloosheid. Als ze een patiènt niet genezen kunnen, blijft volgens hen slechts euthanasie als oplossing over: "Oneindig veel liever spreken artsen over hun technisch kunnen, en, eventueel, als het moet, over hun machteloosheid, zodra hun kunnen het laat afweten. Dat is de houding van de professional [......' (lbid.:65)

In het boek Zelf beschikt van de arts B.E. Chabot, die een depressieve patiënte hulp bij zelfdoding verleende, komt volgens Otten duidelijk naar voren hoe sommige artsen hun macht met een schijnheilig beroep op hun machteloosheid verdoezelen. In zijn boek, stelt Otten, wijst Chabot er herhaaldelijk op dat hij niet aansprakelijk was voor de dood van zijn patiënte: hij had haar slechts geholpen om tot een juiste beslissing te 
komen. De eindverantwoordelijkheid, schrijft Chabot, lag bij de patiënte zelf.

Je kunt Chabots boek als een pleidooi woor het opheffen van het taboe op de maakbare dood lezen. Maar volgens Otten heeft Chabot zijn boek geschreven om het overschrijden wan een taboe goed te praten. Chabot; zegt hij, draagt in zijn boek voortdurend argumenten aan om te bewijzen dat zij bepaalde wat hij moest doen. Zodoende, meent Otten, vraagt Chabot de lezer hem van machtsmisbruik vrij te pleiten:

De titel van het boek is bijzonder goed gekozen - vooropgesteld dat die slaat op alleen Netty's dood. Slaat hij ook op Chabots aandeel, dan had de titel niet slechter kunnen zijn: Netty's dood is nu juist waarover hij, zo beweert hij zelf, niets te zeggen had; het was haar bezit, haar rijkdom, en daar heeft hij zich naar gevoegd. Hij was haar instrument. Het taboe dat hij heeft overschreden moet dan ook door hem compleet worden afgeschaft - anders zou hij, net als Oidipoes, aansprakelijk zijn. Voor die afschaffing vraagt hij onze toestemming.

$(\text { Ibid.:67) })^{29}$

Deze ontkenning van macht heeft volgens Otten met de grootte van die macht te maken. In het geval van euthanasie krijgen we immers een macht in handen gespeeld [...] die te groot voor mensen is'. (Ibid.:63) Dat deze macht voor ons te groot is, ligt daaraan dat de dood onomkeerbar is, en een beslissing over leven en dood onherroepelijk is. De dood, zegt Otten, is geen oplossing, en bovendien geen menselijke oplossing. De dood is immers 'het buitenmenselijke dat op het laatste, uiterste moment kome'. (Ibid.:69) Plegers van euthanasie willen 'gelijk hebben, waar ze alleen maar kunnen weten dat ze iets onherroepelijks hebben gedaan, iets dat nooit meer anders zal kunnen'. (Ibid.:63, cursivering in origineel) Om die onherroepelijkheid niet onder ogen te hoeven zien, schuiven artsen de schuld van zich af. Ze beroepen zich op het overleg, en zeggen dat uiteindelijk de patiënt zelf een beslissing genomen heeft. De wettelijke eis dat artsen altijd met de patiënt en met andere artsen spreken moeten, eer zij tot euthanasie overgaan, geeft artsen dus niet alleen te veel macht, het reikt hun ook de middelen aan die macht te ontkennen.

De onmogelijkheid van rationeel overleg

Onze complexe verhouding tot macht - onze hang naar macht, het gegeven dat we niet in staat zijn met die macht om te gaan en onze ontkenning van macht - maakt de eis van consultatie in de ogen van Otten tot een farce. De zorgvuldigheidseisen wekken de suggestie dat het overleg 
tussen arts en patiẻnt en ook tussen de verschillende artsen letterlijk in redelijkheid verloopt. Maar van redelijkheid kan volgens Otten geen sprake zijn in een situatie waarin het om macht draait. Want hoe komt iemand tot de overtuiging dat euthanasie de enige juiste oplossing is? $\mathrm{De}$ zorgvuldigheidseisen suggereren dat alle artsen en patiënten op een beheerste, niet-emotionele manier tot een inzichtelijke, rationeel verdedigbare conclusie kunnen komen. De werkelijkheid laat volgens Otten het tegenovergestelde zien.

Eerder kwam Ottens kritiek op de euthanasie van Cees van Wendel de Joode ter sprake, die, nadat consultatie had plaatsgevonden en aan alle andere zorgvuldigheidseisen voldaan was, telkens het moment van sterven uitstelde. Dankzij de aanwezigheid van de cameraploeg kreeg Van Wendel de Joode opeens veel aandacht. Die aandacht zorgde er volgens Otten voor dat hij minder graag wilde sterven dan hij eerder te kennen gegeven had. Het probleem was dat Van Wendel de Joode dit volgens Otten niet tegen zijn huisarts kon zeggen - misschien was hij zich van de veranderingen in zijn situatie niet bewust, of misschien was hij bang dat zijn gevoelens niet aansloten bij de gesprekken die hij eerder met zijn huisarts gevoerd had. De omslag in zijn denken, zou je kunnen zeggen, was niet logisch; zijn wens langer te leven stond haaks op de prognoses van zijn huisarts en weersprak zijn eerdere uitspraken.

De manier waarop Van Wendel de Joode met zijn huisarts over euthanasie sprak is volgens Otten typisch voor de gesprekken die de meeste ongeneeslijk verklaarde patiënten met hun artsen voeren. Zo'n gesprek gat in de regel voorbij aan de vele onduidelijke, irrationele en onuitspreekbare gedachten die er door het hoofd van patiënten gaan, en helemaal aan hun onbewuste angsten en verlangens. Het probleem van de discrepantie tussen het zuiver rationele denken en de irrationele gevoelens wordt nog groter wanneer een patiënt zich niet langer kan uiten. De consultatie tussen de verschillende artsen beperkt zich in dat geval tot het bespreken van een wilsverklaring en het speculeren over wat de betreffende patiënt zou willen als hij of zij zijn of haar mening geven kon.

Of een patiënt bij bewustzijn is of niet, te vaak worden er volgens Otten beslissingen genomen die aan de irrationaliteit van ons denken en handelen voorbij gaan, simpelweg omdat er in een gesprek met een arts geen ruimte bestaat voor dubbelzinnigheid en irrationaliteit. Wee degene die ongeneeslijk ziek verklaard is en tegen de algemene opinie in wil blijven leven:

Want degene die zegt: als ik van mijn nek af verlamd ben wil ik dood zijn - in wat voor parket bevindt die zich wanneer hij, eenmaal inderdaad verlamd, tot zijn eigen verbazing en misschien ont- 
zetting ontdekt dat hij nog altijd doodsbang is voor de dood? Dat hij misschien weliswaar vreselijk tegen alles wat nog leven heet opziet - maar eigenlijk nóg banger is dat hij wat er nog is zal verliezen? Natuurlijk bezweren ze dat er dan ook nog sprake moet zijn van een uitgesproken doodswens (vooropgesteld dat je die nog kunt uiten) - maar wát als er in deze verlamde een wens om te leven aan het vechten is om tot uitdrukking te komen; wat als er sprake is van een depressie, een worsteling, een toekenning van betekenis aan toch deze streep leven $[\ldots]$ ?

(Otten 1995b:46)

In het lich $₫$ van deze kritiek klinkt de eis dat een arts met de patiënt tot de overtuiging moet zijn gekomen "dat er voor de situatie waarin deze zich bevond geen redelijke andere oplossing was' (Wet toetsing levensbeëindiging op verzoek en hulp bij zelfdoding, hoofdstuk II, artikel 2, lid Id), in twee opzichten irreëel. De patiënt bevindt zich in een andere situatie dan de arts, en het idee van een redelijke uitweg uit het leven veronderstelt dat het leven zelf uit niets anders dan redelijke beslissingen bestaat. De tragiek van het leven is volgens Otten nu juist dat we voortdurend te maken hebben met 'de kloof tussen hoe het is en hoe het moet zijn". (Ibid.:47) Het leven is in essentie ongrijpbaar en onbegrijpelijk, maar steeds denken we dat het inzichtelijk en beheersbaar is.

Er is nog een andere reden waarom Otten redelijk overleg over euthanasie als een onmogelijkheid beschouwt. In zijn artikel over 'Dood op verzoek' citeert hij een regel uit een gedicht van Ida Gerhardt: 'Sterven is iets waarover men niet spreekt.' Met dat citaat geeft hij te kennen dat hij niet alleen kritiek heeft op de abstracte manier waarop de meeste mensen over concrete situaties praten. Hij laakt het spreken over de dood hoe dan ook. De dood, zegt hij, is iets dat wij niet kunnen begrijpen, waarover wij niet in redelijkheid kunnen praten, en waarover wij al helemaal niet kunnen beschikken:

Ik geloof dat [Gerhardts] woorden niet letterlijk genoeg genomen kunnen worden, nu euthanasie een heus cultuurgoed met mediamieke kwaliteiten aan het worden is. Dat mensen hun laatste zetje, juist omdat hun dood zo bikkelhard kan zijn, kunnen regisseren, met behulp van een huisarts, betekent bijna automatisch dat zij hun eerbied voor de dood beginnen te verliezen. Wat je kunt regisseren, wordt gewoon. Mensenwerk. Bespreekbaar. Uitwisselbaar. Registreerbaar. Uitzendbaar. Herhaalbaar. Verkoopbaar.

(Otten 1994b:2) 
De dood, zegt Otten, is geen mensenwerk. De dood makt deel uit van ons lot. De dood kan niet worden begrepen. Daarom kan de dood geen onderwerp van rationele gesprekken zijn. Naar de dood kan alleen verwezen worden.

\section{Consultatie als medeplichtigheid}

In een vorige paragraaf kwam aan de orde dat patiënten die te kennen geven dat zij sterven willen, automatisch de mensen in hun omgeving medeplichtig maken. Medeplichtig zijn niet alleen de mensen die iemand beletten zichzelf te doden, maar ook zij die voor zelfdoding begrip tonen: het feit alleen dat ze zich met de dood inlaten, makt hen tot tragische personen. Wie zich met de dood inlaat, laat zich met het lot in. Wie zich met het lot inlaat, overtreedt een taboe. Hij of zij zal zijn of haar straf niet kunnen ontlopen. (Otten 1995b) De patiënt die de arts om euthanasie verzoekt, maakt de arts daardoor medeplichtig aan de overtreding van het taboe op moord. Die arts op zijn of haar beurt maakt de collega die hij of zij volgens de zorgvuldigheidseisen consulteren moet, medeplichtig. Zo ontstaat een keten wan mensen die zich schuldig maken aan de overtreding van het taboe dat op het doden van een ander rust. In de ogen van Otten zou de zorgvuldigheidseis betreffende consultatie daarom precies dat uitlokken wat de wet voorkomen wil. De zorgvuldigheidseis betrekt een groot aantal mensen bij het overtreden van het verbod op de doding van een medemens. Hun medeplichtigheid aan moord wordt door de wet gesanctioneerd.

\section{Slotsom}

Onder de punten $c$, d en e van de zorgvuldigheidseisen van de wet op euthanasie staat vermeld dat euthanasie niet mag plaatsvinden als er geen overleg en consultatie heeft plaatsgevonden. Overleg en consultatie moeten plaatsvinden tussen de arts en de patiënt, en ook tussen de arts en een onafhankelijke collega.

De wet schrijft ook de aard van de consultatie voor. De arts moet de patiënt vertellen wat diens vooruitzichten zijn. Arts, patiënt en collegaarts moeten vervolgens tot de overtuiging komen dat er geen 'redelijke andere oplossing' is dan euthanasie.

Een van Ottens bezwaren tegen de legalisering van euthanasie heeft te maken met de onmogelijkheid van mensen om macht af te wijzen. Iedereen die macht in handen krijgt, meent hij, wil die macht ook gebruiken. De gevolgen zijn volgens Otten catastrofaal. Artsen gaan bijvoorbeeld door met een euthanasieprocedure, ook als de patiënt zich bedacht heeft. In het ergste geval laten artsen, opdat zij zelf de handen in onschuld wassen kunnen, de uiteindelijke beslissing aan de patiënt over. Bovendien 
weert Otten zich tegen de aanname dat wre op een strikt rationele manier over ziekte en dood kunnen spreken. De zorgvuldigheidseis die bepaalt dat artsen in geval van een euthanasieverzoek moeten nagaan of er geen 'redelijke andere oplossing' is, veronderstelt dat we al onze beslissingen op een volkomen rationele manier nemen kunnen. Het probleem, stelt Otten, is dat een zuiver rationele redenering voorbijgat aan de wirwar van gevoelens en gedachten waaruit ons dagelijks leven bestaat. Als de gedachte dat we ons leven volgens rationele principes inrichten al op een misvatting berust, hoe zouden we dan op rationele gronden een beslissing kunnen nemen over de dood? De zorgvuldigheidseis lijkt ervan uit te gaan dat niet-rationele beslissingen niet valide zijn. Angst voor de dood bijvoorbeeld zou geen argument tegen euthanasie zijn. Mensen die wilsonbekwaam zijn geworden, maar eerder te kennen hebben gegeven dat zij onder bepaalde omstandigheden om euthanasie zouden vragen, lopen daardoor de kans uiteindelijk toch tegen hun wil te sterven. Volgens hun eerder opgestelde verklaring is er immers geen reden om hen niet dood te laten gaan wanneer ze volgens de artsen uitzichtloos en ondraaglijk lijden.

Ottens tweede bezwaar tegen de aanname dat we in strikt rationele termen kunnen praten over euthanasie en hulp bij zelfdoding, komt voort uit zijn opvatting over de dood. De dood is volgens hem iets waarover wij geen zeggenschap hebben. De dood wordt ons aangedaan; wij zelf mogen ons en anderen de dood niet aandoen. Door artsen en patiënten over de dood te laten beslissen, geeft de wet hun een macht in handen die voor hen te groot is. Wie over de dood praat, makt zich niet alleen schuldig aan overmoed, maar ook aan overtreding van een taboe. Als 'buitenmenselijke oplossing' onttrekt de dood zich bovendien aan ons verstand. De onmogelijkheid over de dood te praten, kan niet op een rationele manier uitgelegd worden - ze is niet beredeneerbaar. Alleen de tragedie, die ons gevoel aanspreekt, die ons het leven laat zien en niet verklaart, kan ons duidelijk maken waarom we niet over de dood kunnen praten. Alleen de tragedie kan ons daarom duidelijk maken waarom we ons niet met de dood mogen inlaten, niet in praktijk en niet in theorie.

Aan consultatie kleeft nog een ander probleem. Wie bij de dood van een ander betrokken wordt, zegt Otten, is automatisch medeplichtig aan de overschrijding van het taboe op moord. In het geval van consultatie maken patiënten en artsen elkaar medeplichtig. De wet maakt daardoor alle betrokkenen bij euthanasie schuldig aan de overtreding van een taboe. 
'Indien de patiënt van zestien jaren of ouder niet langer in staat is zijn wil te uiten', staat er in de zorgvuldigheidseisen, "maar voordat hij in die staat geraakte tot een redelijke waardering van zijn belangen terzake in staat werd geacht, en een schriftelijke verklaring, inhoudende een verzoek om levensbeëindiging, heeft afgelegd, dan kan de arts aan dit verzoek gevolg geven.' (Wet toetsing levensbeëindiging op verzoek en hulp bij zelfdoding, hoofdstuk II, artikel 2, lid 2) Kort samengevat betekent dit dat een arts euthanasie mag toepassen op een patiënt boven de zestien die zich niet meer kan witen, maar die in het bezit is van een schriftelijke wilsverklaring, mits voldaan is aan alle andere zorgvuldigheidseisen.

Otten keert zich om verschillende redenen tegen het gebruik van een schriftelijke wilsverklaring (door hem een codicil genoemd). Ten eerste uit hij kritiek op het idee dat we als gezonde mensen denken te weten hoe we ons als zieken zullen voelen. Wie een codicil invult, stelt Otten, denkt ten onrechte dat hij of zij de toekomst kan bepalen. Een codicil beschouwt hij als de ultieme uitdrukking van de gedachte dat strikt rationele bepalingen en overwegingen belangrijker zijn dan de complexe, dubbelzinnige werkelijkheid. We vergeten te gemakkelijk dat de toekomst niet uit de lucht komt vallen, maar een voortzetting van het heden is. Ten tweede he-kelt Otten het met die abstracties verbonden idee van de dood als oplossing. En ten derde weert hij zich tegen de sociale druk die volgens hem mensen welhaast dwingt een wilsverklaring te ondertekenen.

\section{De toekomst als abstractie}

Mensen die een wilsverklaring invullen, stelt Otten, denken zeker te weten dat zij in de toekomst, als zij ziek of dement zijn en niet langer in staat om zich uit te drukken, dood willen. De dood verwordt op die manier tot een oplossing, die probleem-en pijnloos snel een einde aan mogelijk lijden maakt.

Al eerder kwamen de gevaren van dergelijke gedachten aan de orde. Het is volgens Otten goed mogelijk dat iemand die zich niet meer uiten kan en niet sterven wil, toch gedood wordt omdat hij of zij nu eenmaal een verklaring tot euthanasie ingevuld en getekend heeft. In verschillende essays argumenteert hij bovendien dat het invullen van een wilsverklaring minachting voor ziekte en invaliditeit tot uitdrukking brengt. Wilsverklaringen maken niet alleen duidelijk dat veel mensen een ziekte of een handicap als een abnormaliteit beschouwen, maar ook dat zij het abstracte beeld van de toekomst belangrijker achten dan het concrete heden. Mensen met een wilsverklaring op zak kunnen de imperfecties van het dagelijkse leven niet accepteren. 
Otten beschouwt de vPRo-documentaire 'Lopende zaken', waarin een man en zijn demente vrouw gefilmd worden, als het schoolvoorbeeld van dergelijk onvermogen. Op een gegeven moment komt in deze documentaire een vrijwilliger van de NVVE in beeld. Hij is volgens Otten de vleesgeworden verachting van het heden. In de huidige toestand van de demente vrouw is hij niet geïnteresseerd. Het enige dat hem bezighoudt is de vraag wanneer er aan haar leven een einde gemaakt wordt:

Ook deze vrijwilliger was oud. Hij koesterde zijn papiermassa zoals Charon zijn sloepje. Ik weet niet of hij 'beter dood dan zo' dacht, maar wel dat hij, zoals hij gefilmd was, geen aantoonbaar levendige interesse toonde in hoe deze mensen leefden. Het was of de vraag "hoe gaat het nu", gesteld uit iets anders dan beleefdheid, taboe was.

(Otten 1993b:2)

Sinds de discussie die Drion begonnen is, zegt Otten, "wordt het bijna van politiek belang wie je uiteindelijk het grootste gezag toekent - hij die weergeeft "wat nu eenmaal het geval is", of zij die werkelijk naar de kleinste bewegingen kijkt'. (Ibid.) Met andere woorden, degene die de toestand van een zieke in abstracte en algemene termen beschrijft, krijgt volgens Otten inmiddels meer zeggenschap toegekend dan de zieke zelf.

Als een typisch voorbeeld van het denken in abstracties beschouwt Otten ook de film 'Ich klage an'. Die film wil ons laten denken dat een ziekte zich plotseling openbaart en dat we even plotseling een einde kunnen maken aan een ziek leven. De complexiteit van het gradueel zieker worden en de problemen die een doodswens met zich meebrengen, schrijft Otten, blijven buiten beeld. Wat we in de film niet zien is het leven tussen hoop en vrees en de angst voor pijn die dikwijls even groot is als de angst voor de dood. De zin van ziekte laat de film ons al helemaal niet zien:

Het hele tussengebied van weten dat iemands dagen geteld $z i j n$ en proberen desondanks die dagen te vullen met leven, komt niet aan bod. Zodra de hoofdrolspeelster weet hoe erg het met haar is gesteld wil ze ogenblikkelijk alleen maar dood; dat zij heen en weer geslingerd zou kunnen worden tussen vastklampen aan het leven en diepe moedeloosheid; dat deze beweging tussen hoop en vrezen van haar iemand zou kunnen maken die iets betekent - het komt in deze film domweg niet voor.

(Otten 1994a:2)

Wie een wilsverklaring tekent, zou je kunnen zeggen, stelt zich het leven 
voor zoals deze film suggereert dat het leven is: men leeft, men wordt ziek, men bes》uit dat men maar beter sterven kan en dat doet men dan, snel en zonder enig probleem. De werkelijkheid, zegt Otten, is vele malen ingewikkelder en onduidelijker.

\section{De dood als oplossing}

Waarom tekenen mensen een wilsverklaring als ze nog gezond zijn? Dat doen ze wolgens Otten omdat ze de dood als een oplossing beschouwen. Otten ziet, zoals eerder gezegd, de dood als een buitenmenselijke aangelegenheid. De dood is niet iets dat wij mensen ons toe-eigenen kunnen. Het lot bepaalt wanneer we sterven. Wie denkt dat wij het lot ontlopen kunnen en over onze eigen dood of die van een ander beslissen kunnen, is tragisch. Zo iemand doet iets dat begrijpelijk is maar dat niet mag, en zal hoe dan ook zijn of haar lot niet kunnen ontlopen.

Otten keert zich niet alleen tegen de hoogmoed die uit het zich toe-eigenen van de dood spreekt, maar ook tegen de al te rationele gedachte dat de dood een oplossing van problemen zijn kan. Hij citeert in dit verband Menno ter Braak: 'Een ontsnapping in de dood is een ontsnapping van niets.' (Otten 1995b:46) De dood maakt een einde aan iemands leven; hij doet hem of haar, strikt gezien, niet minder lijden. De dood bevrijdt ons niet van ziekte of depressies, simpelweg omdat de dood ons geen gezond en aangenaam leven biedt. Daarom bekritiseert Otten ook de zelfdoding van Ter Braak als een 'ontsnapping van niets':

Zelfs wanneer je weet dat Ter Braak zich deze ontsnapping gepermitteerd heeft kort na de inval van de Duitsers - dan nog blijft het een ontsnapping van niets. Je hoeft het niet met alles wat W.F. Hermans beweert eens te zijn, om hem dankbaar te zijn voor deze ontmythologisering van Ter Braak. De waardigheid van Ter Brakk schuilt niet in zijn laatste daad, maar in zijn zinnetjes.

(Ibid.)

De dood heeft niets te maken met redelijkheid, en ook niet met waardigheid. Alleen een cultuur die het zuiver rationeel denken belangrijker acht dan de werkelijkheid, kan de dood als een oplossing beschouwen. Zo'n cultuur heeft behoefte aan strikt rationele oplossingen. In werkelijkheid zijn die oplossingen schijnoplossingen. Ook dat leert de tragedie, zegt Otten. Want 'in een tragedie gaat het niet alleen om de vraag of de held strafbaar is, het gaat om iets onrustbarends'. (Otten 1993c:4) De tragedie laat zien dat we ons met euthanasie en hulp bij zelfdoding inlaten met iets dat te groot en te onbegrijpellijk voor ons is. Bovendien leert de tragedie dat we in dergelijke gevallen hoe dan ook last krijgen van ons gewe- 
ten. We mogen immers niet doden, zelfs niet als we allerlei wetten en bepalingen verzinnen die bepalen dat we niet veroordeeld worden en geen straf opgelegd krijgen wanneer we iemand doden of helpen zichzelf te doden. Een ander probleem is dat we nooit echt zullen weten of we juist gehandeld hebben. Als blijkt dat iemand gedood is die op een later tijdstip dankzij de ontwikkelingen van de wetenschap genezen zou zijn, kunnen we onze handelingen niet ongedaan maken.

We mogen geen mensen doden en we mogen niemand daarbij behulpzaam zijn. De dood is geen menselijke aangelegenheid. Daarom put volgens Otten iedereen die bij euthanasie en hulp bij zelfdoding betrokken is, zich uit in verklaringen en discussies die echter nooit kunnen lejden tot werkelijk begrip en een schoon geweten. Ook daarvan geeft het eerdergenoemde boek van Chabot volgens hem een mooi voorbeeld:

Er is een keuze gemaakt die alle andere mogelijkheden uitsloot. Het is voor de toeschouwer onmogelijk om te zeggen dat de gemaakte keuze de juiste is. Er bestaat in tragische dilemma's niet zoiets als de juiste keuze - de keuze is de nederlaag. Er mag geen dochter doodgemaakt worden, er mag geen vader naar de rand van de klip geleid worden, er mag geen drankje aan iemand gegeven worden die dood wil. Als dat laatste wel mocht dan zou Chabotal die moeite niet hebben gedaan om ons te doen begrijpen wie Netty was.

(Ibid.)

Chabot, schrijft Otten, verzuimde de belangrijkste vragen te stellen: 'Hoe kan ik ooit weten of $i k$ het juiste heb gedaan? Hoe moet het verder als niemand mij dat vertellen kan?' (Ibid.) De vermeende redelijkheid van Chabots hulp bij Netty's zelfdoding liep vast op de irrationaliteit van de werkelijkheid, het taboe op moord en de tragiek van het menselijk bestaan.

\section{Sociale druk}

Het lijkt zo makkelijk, zegt Otten in zijn SLA A-lezing: een papiertje invullen om zeker te stellen dat er voor euthanasie gezorgd wordt als je ongeneeslijk ziek verklaard bent maar zelf niet meer kunt zeggen dat je dood wilt. (Otten 1995b:46)

Dat papiertje invullen is inderdaad makkelijk. Zo makkelijk dat je volgens Otten door je omgeving voor gek verklaard wordt als je niet zo'n ingevuld papiertje op zak hebt. Het gemak waarmee wij lang van tevoren euthanasie kunmen regelen en vooral de schijnbare redelijkheid van die regeling, verplichten ons zo ongeveer een wilsverklaring te tekenen. In onze samenleving, zegt Otten, is redelijkheid belangrijker dan twijfel: 
we zijn er steeds op gericht de chaos van het dagelijkse leven te vangen in redelijkheid. Die houding leidt er volgens hem toe dat we zo veel mogelijk aspecten van ons leven proberen te beheersen en te formaliseren, en ook dat we ziekte en invaliditeit zo veel mogelijk buiten het sociale leven proberen te houden. Dat gaat gepaard met een sociale druk die 'je noopt om ook eens voor jezelf te bepalen wanneer je, wat jou betreft, net zo goed dood kunt zijn'. (Ibid.) Die sociale druk heeft er volgens Otten voor gezorgd dat 'er bij het AMC een voorstel ligt om iedereen die opgenomen wordt zo"n formulier vol "tot hiers en niet verders" verplicht te laten invullen'. (lbid.)

Die 'collectieve codicilvorming', zoals Otten het noemt, staat niet alleen haaks op de complexiteit en de chaos van het dagelijkse leven, ze kan ook gevaarlijk zijn. Omdat ze in al haar redelijkheid voorbijgaat aan de onredelijkheid van onze gevoelens, kan het gebeuren dat iemand die een wilsverklaring getekend heeft, ongeneeslijk ziek is en zich niet kan uiten, maar uiteindelijk niet dood wil, volgens de wetten der logica toch gedood wordt. Hoe, vraagt Otten zich af, moet je het winnen van het algemene, rationele codicil, waarin geen plaats voor twijfel is en dat zich niet van andere wilsverklaringen onderscheidt. (Ibid.) Die vraag is retorisch. Zodra je een wilsverklaring ingevuld hebt, kun je het volgens Otten niet van je verklaring winnen. Het is met de wilsverklaring als met de wet op euthanasie zelf: een wilsverklaring gaat voorbij aan de situatie waarin een patiënt zich bevindt, ze is erop gericht twijfels en onduidelijke gevoelens te overstemmen. Omdat een wilsverklaring in onze samenleving als het toppunt van vrijheid en redelijkheid beschouwd wordt, vinden we een uitspraak op papier belangrijker dan de gevoelens van de ongeneeslijke zieke zelf. Dat geldt volgens Otten ook voor de gevoelens van de ongeneeslijk zieke die een wilsverklaring getekend heeft en terug wil komen op zijn of haar besluit:

Een verlamde die niet dood wil, al is het maar uit angst voor het niets waarheen dan dus het ontsnappen zou zijn, is iemand die in onze samenleving met zijn koraalriffen codicillen een oneigentijdse uitspraak doet [...].

(Ibid.)

Otten maant ons de druk van de samenleving te weerstaan en ons niet te laten verleiden tot het invullen van een wilsverklaring. Hij erkent dat dat niet makkelijk is, "want onze oren zitten vol stemmen die "zinloos zinloos zinloos" sissen'. (lbid.) 


\section{Slotsom}

Wilswerklaringen laten volgens Otten zien hoeveel belang veel mensen hechten aan een abstract beeld van de toekomst en hoe makkelijk ze daardoor de concrete werkelijkheid uit het oog verliezen. Wie vastlegt dat hij of zij in geval van een ongeneeslijke ziekte of dementie sterft, vergeet dat ziekte en dementie processen zijn waarbij in de meeste gevallen geen duidelijk punt aan te wijzen is waarop het leven absoluut ondraaglijk geworden is. Het idee dat we ooit zonder benen moeten leven, lijkt ons dikwijls ondraaglijker dan het werkelijk is. Het invullen van een wilsverklaringen laat ons bovendien denken dat wij de toekomst beheersen kunnen. Wie zich tegen dit denken weert, zegt Otten, zal op zijn minst meewarige blikken oogsten: ziekte en invaliditeit worden inmiddels als abnormaliteiten beschouxd.

Het gebruik van wilsverklaringen toont volgens Otten aan hoezeer het rationele denken elk individueel leven beheerst. De veronderstelde redelijkheid van een wilsverklaring dwingt volgens hem bijna iedereen een dergelijke verklaring te tekenen. Diezelfde redelijkheid doet een arts besluiten tot euthanasie over te gaan als een patiënt wilsonbekwaam geworden is: volgens de wetten van de ratio - de patiënt is ongeneeslijk ziek en heeft een verklaring getekend - móét een arts wel tot dat besluit overgaan. Zo maken we het dagelijkse leven ondergeschikt aan het zuiver rationele denken: wie eenmaal a heeft gezegd, zal b ondergaan, of hij of zij zich intussen bedacht heeft of niet. Een wilsverklaring is volgens Otten dus niet alleen een uitdrukking van het idee dat mensen hun leven en de tijd beheersen kunnen. Ze bepaalt de duur van het leven ook werkelijk, omdat degene die een wilsverklaring ondertekend heeft, daarmee zijn of haar eigen doodvonnis heeft vastgelegd.

\section{Samenvatting en conclusie}

In zijn kritiek op de discussie rond de legalisering van euthanasie en hulp bij zelfdoding, weert Otten zich vooral tegen het karakter van die discussie. De manier waarop er over het algemeen over de dood gesproken wordt, is hem te rationeel en te abstract. Het praten in abstracties is volgens hem een gevolg van de heerschappij van de postsocratische filosofie. Dankzij de postsocratische filosofie denken we dat we de complexiteit van de concrete ervaring in strikt rationele begrippen vangen en beheersen kunnen.

Ook de ontwikkelingen binnen de medische wetenschap doen veel mensen geloven dat de wetenschap ons op rationele wijze inzicht biedt in kwesties van leven en dood. Maar dat laatste, stelt Otten, is een illusie. 
Leven en dood kunnen niet met rationele redenen omkleed worden. Het einde van een mensenleven gaat gepaard met gevoelens als angst, verdriet, onbegrip en wanhoop. Deze concrete, complexe en irrationele gevoelens worden volgens Otten in het medisch onderzoek en in de discussie rond euthanasie te vaak buiten beschouwing gelaten. Voorstanders van de legalisering van euthanasie en hulp bil zelfdoding betogen dat de mens een autonoom wezen is dat vrijelijk over zijn dood beschikken mag. Ten onrechte denken ze dat we geheel onafhankelijk, in alle vrijheid en op een weloverwogen manier beslissen kunnen over ons leven en ons levenseinde. Volgens Otten wordt de mens gestuurd door het lot. Het lot is, net als de dood, een buitenmenselijke aangelegenheid. Wij mensen mogen en kunnen ons daarom niet met de dood inlaten. Wie dat wel denkt te kunnen doen, is als de hoofdpersoon van een tragedie: wat zij of hij doet is begrijpelijk, maar niet toegestaan. Bovendien is de mens slechts mens, zegt Otten, voor zover hij met anderen samenhangt. Een leven wordt altijd mede bepaald door andere levens. Iedereen, dus ook een ongeneeslijk zieke, laat zich leiden door de oordelen van zijn of haar omgeving. Patiënten nemen daardoor vaak beslissingen die zij misschien liever niet nemen wilden. Daarom maakt iemand die besluit dat er een einde aan iemands leven gemaakt moet worden, zich niet alleen schuldig aan overmoed, maar ook aan het betrekken van anderen bij de overtreding van een taboe. Dat geldt voor iedereen die te maken heeft met euthanasie of hulp bij zelfdoding. Het gevolg is dat iedereen die bij euthanasie of hulp bij zelfdoding betrokken is, last zal hebben van schuldgevoelens, ook al weten zij hun betrokkenheid nog zo vaardig goed te praten. Zij hebben immers een macht gebruikt die hun niet toekomt.

Ook hekelt Otten het idee dat er op wetenschappelijke wijze vastgesteld kan worden of iemands lijden ondraaglijk is. Lijden, zegt hij, is niet meetbaar en niet voorspelbaar. De mate van het lijden wordt voor een groot deel bepaald door de situatie waarin een patiënt zich bevindt. Als die situatie verandert, verandert ook het lijden. We mogen bovendien niet vergeten dat lijden bij het leven hoort. Lijden maakt het leven niet zinloos, zoals veel mensen denken, maar geeft het leven een bepaalde betekenis.

Mensen die over de dood praten, laten zich volgens Otten met een buitenmenselijke oplossing in. Zij eigenen zich een macht toe, die hun niet toekomt en waarmee zij niet om kunnen gaan. Artsen en patiënten die over euthanasie praten, maken elkaar medeplichtig aan het overtreden van een taboe. Over de dood kun je niet op zuiver rationele wijze praten, laat staan over moord.

Schriftelijke wilswerklaringen ten slotte beschouwt Otten als het top- 
punt van overmoed. Wie een wilsverklaring tekent, denkt dat hij of zij de toekomst bepalen kan.

De zorgvuldigheidseisen gaan volgens Ottens essays in elk opzicht voorbij aan de situatie waarin een ongeneeslijk zieke zich bevindt. Toch meent Otten dat zijn kritiek op de discussie over euthanasie en op de euthanasiepraktijk in zijn essays onvolledig tot uiting komt. Zijn artikelen leveren krantenkennis op, zegt hij, maar geen doorleefde kennis. De krantenkennis komt op een rationeel niveau tot stand.

Om erachter te komen wat de wet op euthanasie werkelijk teweegbrengt moeten we, zegt hij, zijn roman Ons mankeert niets lezen. Ons mankeert niets gaat over een arts die tegen zijn wil betrokken wordt bij de zelfverkozen dood van een collega. Deze roman moeten we volgens Otten beschouwen als een alternatief voor de discussie over euthanasie en hulp bij zelfdoding, want een roman, zegt hij, geeft de complexiteit van de werkelijkheid beter weer dan elke strikt rationele discussie. Daarom biedt Ons mankeert niets een beter beeld van de problemen die ontstaan door euthanasie en hulp bij zelfdoding. Otten nodigt ons uit zijn roman te lezen en niet literatuurwetenschappelijk te onderzoeken; het lezen van zijn roman, zegt hij, geeft een adequatere kennis van de werkelijkheid dan welke analyse ook. (Otten 1995a) In de volgende twee hoofdstukken wordt daarom nagegaan tot welke kennis het lezen van Ons mankeert niets precies voert. 



\section{Ons mankeert niets als tragedie}

In 1995 organiseerde het dagblad Trouw samen met Medisch Contact, het weekblad van de Koninklijke Nederlandsche Maatschappij tot bevordering der Geneeskunst, een discussie naar aanleiding van Ottens roman Ons mankeert niets. Otten zelf schreef een inleiding op die discussie, die in Trouw van 21 januari 1995 gepubliceerd werd.

In dit artikel, getiteld 'Het idee van een dood die niemand belast', legt Otten uit wat voor hem de belangrijkste redenen waren om het boek te schrijven. Een roman, legt hij uit, geeft beter dan een essay of een betoog de kennis weer die de concrete, dagelijkse ervaring biedt. Die ervaring leert ons dat ons bestaan, anders dan we doorgaans denken, niet bepaald wordt door strikt rationele, abstracte en louter zelfstandig gemaakte beslissingen, maar door emoties en intermenselijke verhoudingen. Die kennis, schrijft hij, is kennis "die luistert naar de naam ervaring, en die alles te maken heeft met een idee dat mensen hun eigen werk niet zijn, en deel uitmaken van een weefsel van emoties en betrekkingen, waarvan zij de kracht pas beginnen te kennen wanneer het te laat is'. (Otten 1995a)

Bovendien deed het schrijven van Ons mankeert niets hem beseffen dat het idee van een vrije wil een illusie is. Hij merkte dat hij zich bezighield met iets dat uitsteeg boven de persoonlijke ervaring. Dat gaf hem het inzicht dat onze levens voor een groor deel door machten buiten onszelf bepaald worden:

Wanneer je een roman schrijft ondervind je dat op de meest concrete manier aan den lijve: je vertelt maar heel ten dele je eigen verhaal. Zodra je iets schrijft wat op een tragedie wil lijken, mak je met je verhaal deel uit van een eeuwenoude, tragische inspanning; het genre is [.... wijzer dan de schrijver, en ongemerkt voeg je je naar de tragedies die - vaak zonder dat je het beseft -, je de ogen openen voor het noodlottige en gedrevene.

(lbid.) 
'Tragisch' is het trefwoord van Ottens poëtica. De literatuur toont volgens hem aan dat het menselijke bestaan wan tragiek doortrokken is. Wii denken weliswaar dat wij in vrijheid strikt rationele beslissingen nemen, maar wij zijn voortdurend gevangen in een tragische, niet te winnen strijd tussen beheersen en beheerst worden. De tragedie laat zien dat we steeds dingen doen die niet mogen, maar die we in onze overmoed en in onze hang naar rationele verklaringen en ons verlangen naar macht toch doen. Dat geldt vooral voor wie zich met euthanasie inlaat. Wie een ander helpt te sterven, denkt het lijden van een mens zelfstandig en op een zuiver rationele manier op te kunnen lossen. lemand die zo handelt ontkent dat ons handelen eerder door emoties gestuurd wordt dan door rationele overwegingen. Bovendien vergeet diegene dat de dood een 'buitenmenselijke aangelegenheid' is. Wie met euthanasie of zelfdoding te maken krijgt, neemt altijd een verkeerde beslissing. "Dat is de paradoxale beweging van veel tragedies, schrijft Otten, 'hoe dichter iemand staat bij het kunnen nemen van andermans leven, des te minder handelt hij of zij uit wat wij dolgraag "vrije wil" zouden noemen.'(Otten 1995d:64)

Otten noemt Ons mankeert niets nadrukkelijk een "gooi naar de tragedie'. (Otten 1995b:48) Met deze roman wil hij, zoals hij in zijn lezing 'Het verschuiven van schaamte" uit 1995 uitlegt, tot uitdrukking brengen dat het taboe op het doden van een ander, anders dan de voorstanders van de legalisering van euthanasie menen, niet kan en niet mag worden doorbroken. En dat is niet alleen omdat de dood een 'buitenmenselijke aangelegenheid' is. Als we het taboe op hulp bij zelfdoding zouden opheffen, en onze schaamte leren overwinnen, ontstaan een nieuw taboe en een nieuwe schaamte: het taboe op en de schaamte voor lijden: '[...] want wat $\mathrm{ik}$ vermoed is dat het ontlopen van de ene schaamte, ten overstaan van het ene taboe, een nieuwe, onheilspellende schaamte creëert - de schaamte voor mensen die lijden.' (Ibid.)

Volgens de flaptekst van Ons mankeert niets is de roman voor alles 'een gewetensonderzoek van een man die zich geplaatst weet voor een gevreesde vraag: wat doe je als je weet dat iemand dood wil?' Het antwoord op die vraag is afhankelijk van de kennis die de roman biedt. Als we op Ottens essays afgaan, dan is er volgens hem slechts één antwoord mogelijk: distantie bewaren. In zijn artikel over de zelfdoding van Adriaan Venema bijvoorbeeld hekelt Otten het gedrag van diens vrienden. Toen die van Venema's zelfdodingplannen hoorden, toonden ze volgens Otten te veel begrip. Zij probeerden hem niet af te houden van zijn voornemen, maar steunden hem daarin. Zodoende lieten ze toe dat hij een taboe verbrak en hen in die onfortuinlijke daad meesleurde. Willens en wetens werden zij medeplichtigen in een moordzaak. Otten meent dat 
zij zich op zijn minst hadden moeten distantiëren van Venema's plannen. Dit is wat zij tegen hun vriend hadden moeten zeggen: 'Te doet maar wat je doen moet, maar iemand die mij dwingt om dadeloos respect te betuigen voor deze beslissing, die vergt te veel van me. Want zolang je mij wilt vertellen wat je van plan bent, forceer je mij een oordeel over je leven uit te spreken dat $\mathrm{ik}$, zolang ik zelf wil leven, nooit en nimmer vellen wil: ik weiger.' (Otten 1993a) Maar die uitspraak doet Otten in een essay. Het is de vraag of het lezen van zijn roman, waarin, zoals Otten stelt, de complexiteit van de dagelijkse ervaring tot uitdrukking komt, tot eenzelfde, eenduidige conclusie voert.

In dit hoofdstuk wordt Ons mankeert niets gelezen zoals Otten het boek volgens eigen zeggen bedoeld heeft: als een tragedie. In het eerste deel geef ik de inhoud van Ons mankeert niets weer. Omdat deze studie in het kader staat van de discussie over praktische omgang met de abstracte wet, zoals ook Otten die verwoordt, wil ik in het volgende deel nagaan hoe in de roman Ottens kritiek op de verschillende aspecten van de euthanasiediscussie en van de wet op euthanasie tot uitdrukking komt. In dit kader wil ik onderzoeken hoe de twee artsen in dit drama omgaan met het lijden van hun patiënten en hoe ze reageren op de doodswens van ernstig zieken. Allereerst wordt naar de "paradoxale beweging' van deze tragedie gekeken. In hoeverre denkt de ikfiguur, een jonge huisarts, te handelen tit eigen wil, en in hoeverre wordt zijn leven bepaald door het lot? En wat gebeurt er als iemand denkt dat hij op een strikt rationele manier beslissen kan over zijn leven en over dat van anderen? Vervolgens ga ik na hoe Otten in zijn roman uitdrukking geeft aan het thema 'uitzichtloos en ondraaglijk lijden'. De vraag in hoeverre zelfdoding anderen tot medeplichtigen maakt, staat centraal in de daaropvolgende beschouwing. Ten slotte ga ik in op de vraag naar het belang van geschreven verklaringen.

\section{Ons mankeert niets}

Ons mankeert niets is geschreven vanuit het perspectief van Justus Loef, een nog jonge huisarts. Justus is getrouwd en heeft twee dochtertjes. De roman is zijn verslag van wat er tijdens een dag en een nacht - die van achtentwintig op negenentwintig maart om precies te zijn - in zijn praktijk in Heimwou, een fictief, middelgroot West-Fries dorp, heeft plaatsgevonden. ${ }^{30}$

Justus is de jonge, analytisch denkende opvolger van dokter Berend Daan. Dokter Daan kun je een dorpsdokter van de oude school noemen: hij is autoritair, maar ook vaderlijk. Hij vertrouwt eerder op zijn ervarin- 
gen dan op de theorie. ${ }^{31}$ Na zijn pensionering is dokter Daan in Heimwou blijven wonen. Niet al zijn oud-patiënten accepteren Justus als nieuwe huisarts. Een vrouw die door de artsen in het ziekenhuis is opgegeven, weigert bijvoorbeeld door Justus behandeld te worden.

Met een van Daans vroegere patiënten, Steffie Capitu, heeft Justus een verhouding. Steffie is net als Hilde, Justus' vrouw, in Heimwou opgegroeid. Justus kent Steffie nog van vroeger. Ze zaten bij elkaar in de klas toen Justus enige tijd bij familie in het dorp logeerde. Steffie is kunstenares en woont in een huisje aan de duinrand. Justus pleegt haar te bezoeken tussen zijn visites door.

Op de ochtend van achtentwintig maart krijgt Justus via zijn assistente Zaza een boodschap van dokter Daan. Dokter Daan laat Justus vragen de volgende dag om half vier uur bij hem langs te gaan. Dokter Daan laat niet weten waarom en Justus besteedt verder geen aandacht aan het bericht. Justus houdt zijn spreekuur en krijgt aan het einde daarvan de dochters en de echtgenoot van mevrouw Sleutel, een doodzieke patiënte, op bezoek. Daarna rijdt hij visites. Gedurende die dag krijgt hij op verschillende manieren met dokter Daan te maken. Eén van Justus' patiënten vertelt dat dokter Daan kruisjes zette op de kaarten van sommige vrouwelijke patiënten. Die kruisjes geven volgens haar het aantal intieme contacten weer tussen dokter Daan en de betreffende patiënte. Het blijkt dat niet alleen op haar kaart kruisjes staan, maar ook op de patiëntenkaarten van Steffie, Hilde en mevrouw Sleutel.

Al deze vrouwen herinneren Justus in de loop van de dag eraan dat het de tweede sterfdag is van Evelien, de vrouw van dokter Daan. Evelien Daan was in een depressie geraakt nadat haar zoon bij een verkeersongeluk om het leven gekomen was. Toen zij zelf sterven wilde, heeft dokter Daan haar geholpen zichzelf te doden. De vrouwen maken zich zorgen om dokter Daan. Steffie en Hilde zijn bang dat ook hij zichzelf zal doden. Langzamerhand groeit die angst ook bij Justus. Hij begint zich af te vragen waarom dokter Daan hem bij zich thuis ontboden heeft.

Na zijn visites gaat Justus naar Steffie, die hem vertelt dat ze voor het eerst in jaren Hilde is tegengekomen. Nu ze Justus' vrouw heeft gezien, wil ze haar verhouding met Justus beëindigen. Tijdens hun gesprek gaat de telefoon. Justus hoort Steffie drie keer "Berend' roepen, maar merkt dat ze geen antwoord krijgt op haar geroep. Justus gaat op verzoek van Steffie bij dokter Daan langs. Hij belt aan, maar er wordt niet opengedaan.

Thuis wacht een ongeruste Hilde. Na het avondeten gaat Justus terug naar de praktijk en bezoekt vervolgens mevrouw sleutel, de ongeneeslijk zieke vrouw. Die geeft te kennen dat ze alleen dokter Daan zien will. Justus raakt hierdoor geïrriteerd, maar zodra hij begrijpt dat ze bang is dat 
alleen dokter Daan op haar verzoek om euthanasie zal ingaan; belooft hij dat ook hij haar bij het sterven helpen zal.

Na zijn bezoek aan mevrouw Sleutel gaat Justus nog een keer bij dokter Daan langs. Deze keer blijkt de deur van het slot te zijn. Justus gaat naar binnen, roept, maar zoekt dokter Daan niet echt. Als hil geen antwoord krijgt op zijn geroep, gaat hij weg. Hij rijdt door naar Steffie, die zich steeds meer zorgen maakt om dokter Daan. Een vrouw belt Justus via zijn draagbare telefoon om hem te vragen naar haar kind te kijken. Het kind heeft oorpijn en koorts, maar Justus vindt de klachten te weinig serieus om het kind te onderzoeken. Hij is inmiddels te zeer geoccupeerd met zijn eigen problemen om voldoende aandacht aan zijn patiënten te schenken.

Justus brengt Steffie kort daarop naar dokter Daan. Hijzelf rijdt door naar zijn praktijk, waar hij besluit de nacht door te brengen. Daar confronteert Hilde hem met zijn verhouding met Steffie. Ze heeft diezelfde avond Justus en Steffie in Steffies huis geobserveerd.

Voordat Justus naar bed gaat, loopt hij nog een keer naar het huis van dokter Daan. Hij gaat naar binnen, en hoort vanachter de slaapkamerdeur dokter Daan en Steffie met elkaar praten. Dan gaat hij terug naar zijn praktijk en valt in slaap.

De volgende ochtend houdt Justus zoals gewoonlijk spreekuur. In de loop van de ochtend krijgt hij te horen dat het kind met oorpijn meningitis heeft. De ouders willen weten waarom Justus niet langsgekomen is. 's Middags rijdt Justus visite, en om half vier belt hij, zoals gevraagd, bij dokter Daan aan. Weer reageert niemand op zijn gebel en ook nu weer is de deur open. Justus gaat naar binnen. Hij vindt dokter Daan, die dwars over de wc ligt. Dokter Daan is dood. Hij heeft vermoedelijk zichzelf omgebracht. Zijn eigen patiëntenkaart houdt hij in zijn hand geklemd. "Mij mankeert niets', staat er op de kaart. Justus belt de politie en vult de Verklaring van Overlijden in. Op dat moment begaat hij een overtreding. Justus meldt niet dat hij vermoedt dat dokter Daan zichzelf gedood heeft. Hij schrijft op dat dokter Daan een massaal hartaanval gehad heeft. Vervolgens gaat hij naar Steffie. Als hij haar niet thuis aantreft, rijdt hij door naar zijn boot in Friesland. Daar vindt hij een roman waarin hij eerder de volgende passage onderstreept heeft: "wij bestaan alleen voor zover we samenhangen met anderen.' In zijn boot schrijft Justus een verklaring, gericht aan een ' $U$ ' die hij niet bij zijn of haar naam noemt. ' $U$ hebt gegronde redenen om aan te nemen dat de dood van dokter daan geen natuurlijke was', schrijft hij. Met die verklaring eindigt en begint zijn verhaal. Ons mankeert niets is de verklaring van Justus' betrokkenheid bij de dood van dokter. Daan en een apologie voor het verkeerd invullen van de Verklaring van Overlijden. 
'Welke scènes kun je bedenken als iemand de aankondiging krijgt van zijn dood?' vraagt Otten zich af in een interview over Ons mankeert niets. 'Welke scènes zijn er als je van mensen af wilt, omdat ze kwijlerig zijn geworden en lastig? Wat gebeurt er dan tussen mensen?' (Tromp 1995:1)

De dood van dokter Daan op zich is, grof gezegd, niet het eigenlijke probleem, noch het eigenlijke thema van de roman. Van dokter Daans dood is slechts sprake aan het einde van de roman, als Justus het lichaam van dokter Daan vindt. Hoe dokter Daan gestorven is, krijgen we niet te horen.

Belangrijker dan de dood van dokter Daan is wat er aan die dood voorafgaat. Het gaat Otten, zoals hij in het interview zegt, om de manier waarop de personages die vermoeden dat dokter Daan een einde aan zijn leven will maken, met elkaar omgaan. Tijdens de dag en de nacht voorafgaande aan de dood van dokter Daan, worden hun verhoudingen tot elkaar bepaald. Binnen die verhoudingen speelt de vraag naar het recht op zelfbeschikking een grote rol. In de eerste zorgvuldigheidseis van de wet op euthanasie en hulp bij zelfdoding wordt gesteld dat er altijd sprake moet zijn van een vrijwillig en weloverwogen verzoek. In Ons mankeert niets komt ook de vraag naar het recht van de arts op beschikking van andermans leven aan de orde. Als we de roman lezen volgens Ottens opvatting van een tragedie, valt er geen verschil te maken tussen het een en het ander. ledereen die meent vrijelijk te kunnen beschikken over dood en leven maakt zich schuldig aan hoogmoed: die beseft niet dat de dood een 'buitenmenselijke oplossing' is, en dat wij niet zelf ons lot bepalen kunnen. De hoogmoed van artsen is hoogstens complexer dan die van patiënten, omdat zij niet alleen macht denken te hebben over hun eigen leven, maar ook over dat van anderen. Dat geldt voor dokter Daan, die zowel arts als patiënt is, maar vooral voor Justus.

Als we Ons mankeert niets volgens Ottens begrip van een tragedie lezen, zijn alle personages verwikkeld in een drama waarin het taboe op moord verschillende malen overtreden wordt en waarin nauwelijks sprake is van weloverwogenheid en vrijwilligheid. Iedereen die betrokken raakt bij euthanasie of zelfdoding, wordt gestraft. Dokter Daan heeft zijn vrouw bij haar zelfdoding geholpen en doodt een jaar later zichzelf. Justus geeft een patiënt een overdosis pijnstillers, belooft iemand bij het sterven te helpen en is uiteindelijk verantwoordelijk voor de dood van dokter Daan. De meeste vrouwelijke personages in de roman, die soms als het koor in een Grieks drama lijken te fungeren, proberen Daan af te houden van zijn voornemen zichzelf te doden. Toch moeten ook zij boe- 
ten voor Justus" en Daans overtredingen van het verbod op moord. Steffie verliest de man die ze werkelijk liefheeft en Hilde verliest haar echtgenoot. Justus raakt waarschijnlijk niet alleen zijn praktijk kwijt, maar ook zijn gezin, zijn echtgenote en zijn minnares.

Die afhankelijkheid van het lot staat in grote tegenstelling tot het beeld dat Justus van zichzelf heeft. Hij ziet zichzelf het liefst als een moderne wetenschapper, die als een god vrijelijk beschikt over leven en dood. Hij geeft zijn patiënten het gevoel dat ze zelf over hun eigen levenseinde mogen beslissen, maar in werkelijkheid bepaalt hij of en wanneer iemand uitzichtloos en ondraaglijk lijdt en daarom voor euthanasie in aanmerking komt. Hij beschouwt zichzelf als een strikt rationeel denkende en handelende arts die zijn emoties buiten zijn werk laat. Wanneer bijvoorbeeld Zaza, zijn assistente, hem op maandagmorgen de patiëntenkaarten overhandigt en meldt dat meneer Galesloot, een van Justus' patiënten, in het weekend overleden is, neemt Justus als geroutineerde huisarts zonder enige emotie kennis van dit feit. Heel even maar toont hij compassie. 'Ach,' zegt hij, 'dood is Galesloot.' Maar dan roept hij zichzelf tot de orde. Meneer Galesloot heeft Justus ooit gevraagd hem te laten sterven zodra hij ondraaglijk lijden zou. Omdat meneer Galesloot opgegeven is door de specialisten, heeft Justus daartegen geen bezwaar gehad. Vlak voor het weekend heeft Justus meneer Galesloot een extra dosis pijnstillers gegeven. Daarna heeft hij de patiënt overgedragen aan zijn collega Verdurmen, die weekenddienst heeft. Justus bedenkt dat hij Verdurmen bellen moet, opdat ze 'het geval' Galesloot op professionele manier kunnen afhandelen. Toch klinkt in zijn overwegingen een zweem van twijfel en zelfspot door:

Natuurlijk vraag ik Verdurmen straks als hij belt niet naar de precieze aard van zijn handelingen. Hij belt zijn Verklaring van Overlijden door, die ik ongezien overneem als had ik Galesloot persoonlijk geschouwd, en even zal het zijn alsof twee goden elkaar bellen en niet hoeven te vertellen hoe noodlottig ze zijn, want ze kennen het noodlot, ze schikken zich er beter naar dan wie dan ook, ze kennen. En ze laten elkaar zijn zoals ze zijn, en waar ze zijn: alleen, afgezonderd in de schemerige ruimte van aarzelingen en handelingen.

(Otten 1994d:24-25, cursivering in origineel)

Artsen, zegt Justus, bepalen of en wanneer een patiënt ongeneeslijk ziek is en ondraaglijk lijdt. Zij hebben ook in dit geval beschikt: de zieke is opgegeven en wordt niet langer behandeld. Justus beseft echter dat hij en zijn collega's veel minder zeker zijn van de rechtmatigheid van hun handelingen dan zij doen voorkomen. Ze bevinden zich, zegt Justus, in de 
schemerige ruimte wan aarzelingen en handelingen' - ze denken het een en doen het ander. Ze presenteren zich tegenover hun patiënten en hun collega's alsof ze zonder enig probleem over leven en dood beschikken kunnen. Die houding bevalt Justus, maar ze veroorzaakt bij hem ook onrust. Die onrust draagt hij mee bij alles wat hij doet. Voortdurend wordt hij geplaagd door ambivalente gevoelens, en voortdurend probeert hij die gevoelens weg te redeneren. Het recht op zelfbeschikking, of, in het geval van artsen, het recht op beschikking, is iets dat, zo beseft Justus, in feite alleen op papier bestaat.

Toch vertrouwt Justus liever op dat papier dan op zijn gevoelens. Hij probeert een scherp onderscheid te maken tussen gevoel en verstand. Zijn handelen legitimeert hij door middel van strikt rationele gedachtegangen, regels en verordeningen. In sommige gevallen verschaft hem dat een alibi, zoals in het geval van het kind met oorpijn. Oorpijn en koorts zijn volgens de officiële medische voorschriften geen aanwijzing voor meningitis. Zo praat hij voor zichzelf goed dat hij liever naar Steffie gegaan is dan naar het zieke kind.

Justus' pogingen een tweedeling te maken tussen zijn emoties enerzijds en een strikt rationeel denken anderzijds, komen ook tot uitdrukking in de manier waarop hij naar zijn patiënten luistert. Van dokter Daan heeft hij geleerd dat een patiënt altijd twee klachten heeft. De eerste klacht is lichamelijk, de tweede bijna altijd psychisch. Een moeder wil bijvoorbeeld dat Justus naar de longen van haar dochtercje luistert. Terwijl ze haar kind uitkleedt, ziet Justus een bloeduitstorting op het schouderblad van het meisje. Hij merkt dat de vrouw moe is. Hij herinnert zich dat de vader zonder werk zit, en concludeert dat de vader van het meisje zijn vrouw en zijn kind mishandelt. De vrouw en het dochtertje lijden niet zozeer door lichamelijke ongemakken als verkoudheid of vermoeidheid, als well door de spanningen thuis. Maar op de onuitgesproken tweede klacht gaat Justus niet in. Ook in andere gevallen hoort hij de tweede klacht wel, maar behandelt hij die niet. Uit hoofde van zijn beroep, meent hij, kan hij alleen iets doen aan de eerste klacht. De eerste klacht is algemeen, meetbaar en behandelbaar - de tweede persoonlijk en complex. Aan de tweede klacht wil hij niets doen. Justus houdt zich aan de regels, en bevestigt zo zijn macht als arts:

Die tweede, de dikwijls alomvattende - daarvan maakte ik pas op het allerlaatste moment duidelijk dat ik haar had gehoord. Een enkele keer schreef ik haar steekwoordsgewijs in op de patiëntenkaart. Zoon wil haar nooit meer zien. Bang voor mannen kloppend op het raam 's nachts. Meent in een vorig leven een verkrachte non te zijn geweest. Droont elke nacht van overreden kind. Vreest erfelijke ziekte bij dochter. 
Ik heb hem gehoord, alles heb ik gehoord wat er gezegd werd zolang ik aanraakte. En ik besloot het consult even oppermachtig als mächteloos. Ik zei: aan uw eerste klacht gaan we werken.

(Ibid.s)

Justus wil niet aan de tweede klacht werken, omdat hij afstand tot zijn patiënten houden wil. Dat blijkt ook uit de manier waarop hij hen aanraakt. Aanraking wordt door hem 'betasting' genoemd. De 'betasting" moet volgens een bepaald patroon verlopen, opdat ze een handeling kan blijven die de arts en de patient eerder van elkaar scheidt, dan dat ze hen tot elkaar brengt. Het aanraken gebeurt hier op een bijna eenzijdige manier. De reactie van de patiënt op dit gebaar is onbelangrijk. Waar het om gaat, is arts en patient te herleiden 'tot een lichaam en tot huid', en daardoor beiden als het ware te depersonaliseren. Justus zelf vergelijkt zijn wijze van aanraken met de herderlijke, maar tegelijk hiërarchische manier waarop een priester zijn parochianen aanraakt:

De betasting diende te volgen op een zo kalm mogelijke, terloopse aanraking, van de pols, de onderarm, de schouder. Afhankelijk van de aard van het onderzoek bleef ik zo veel mogelijk in fysiek contact, zelfs wanneer dit medisch gesproken niet nodig was. I $k$ deed dit vooral omdat ik hield van de betovering van het ogenblik, deze overgang van taal naar vingertop. Het herleidde niet alleen de patiënt, maar ook mij tot een lichaam en tot huid. Ik heb de patiënt hierbij nooit aangekeken, maar me altijd geconcentreerd op mijn handen, ook als ik naar niets op zoek was. Ik beleefde er iets aan wat eerder priesterlijk was dan sexueel. Ik wilde de zielen van mijn praktijk aangeraakt hebben, allemaal, met eigen handen.

(Ibid. .7)

Justus" verlangen naar orde en afstand komt ook tot uitdrukking in de manier waarop hij omgaat met de man en dochters van mevrouw Sleutel. Als we afgaan op zijn commentaar op de verwijzingsbrief van de specialist en de nonchalante manier waarop hij het gezin Sleutel bejegent, lijkt hij niet echt geinteresseerd in hun problemen. De vrouw is opgegeven door de specialist, en heeft daarom volgens Justus niet veel aandacht meer nodig:

Ik las de brief van de specialist. Klare, dodelijke taal. Mevrouw Sleutel had een laatste bloedtransfusie gehad, deze maandagmorgen. Ze voelde zich nu wel. Gezien haar hoge leeftijd, gezien het feit van maar één nier, gezien de uitzaaiing, kwam zij voor verdere bloedver- 
versing niet meer in aanmerking - aldus hadden beschikt de goden op Interne Geneeskunde van het Rijksziekenhuis te A.

Ik liep naar de wachtkamer. Neuriede, wat me kwam te staan op een zorgelijke, waarschuwende blik van Zaza, achter haar balie tegenover de wachtkamer.

(ibid.:39)

De jonge dokter spreekt op routineuze wijze met de man en dochters van de zieke vrouw. Hij gaat nauwelijks in op hun opmerkingen, maar belooft later die dag nog een keer langs te komen. Op dat moment heeft hij eigenlijk maar én gedachte: het bezoek aan zijn vriendin Steffie. Die gedachte is vermengd met gevoelens van genot en schuld. De schuldgevoelens worden versterkt als hij hoort dat zijn vrouw geprobeerd heeft hem te bereiken. Justus waant zich bespied en betrapt. Even lijkt hij te beseffen dat hij slechts spéélt dat hij een rationeel denkend en handelend arts is:

Mijn spreekkamer heeft geen ramen, ik bevond mij in het binnenste van mijn doolhof, toch had ik nu de sensatie vanaf de Hoofdstraat volledig zichtbaar te zijn. Het bezige baasje-op-leven-en-dood, zittend aan zijn pientere diagonale bureau, de aandachtige luisteraar naar andermans angsten, ontwarder van knopen, niets mankeerde hem, alles liep op bureaustoelwieltjes - maar waarom keek heel Heimwou plotseling door de jonge dokter heen?

(Ibid.:44)

Paniek overvalt hem als hij denkt dat het toegezegde bezoek aan dokter Daan samenvalt met zijn afspraak met Steffie. Maar Zaza stelt hem gerust. Dokter Daan wil dat Justus de volgende dag pas komt. Hij hoeft dan niet aan te bellen, voegt ze eraan toe: de deur zal llos staan. Justus reageert opgelucht.

Terugblikkend op de gebeurtenissen van achtentwintig en negenentwintig maart, moet Justus vaststellen dat hij al op de eerste dag begon te beseffen dat er iets merkwaardigs aan de hand was met dokter Daans verzoek. Hij moet het begrepen hebben, zegt hij, vanaf het moment dat het tot hem doordrong dat dokter Daan hem de volgende dag pas wilde zien. Dat besef neemt de vorm van een onderhuidse dreiging aan en vermengt zich met Justus" ambivalente gevoelens over de macht die hij zich als arts aanmeet. Maar bijna meteen kiest Justus ervoor voorrang te geven aan zijn rationele, wetenschappelijke, professionele houding. Die stelt hem in staat zijn geweten te negeren: dokter Daan mankeert toch immers niets? Wie niets mankeert, heeft geen recht op doktersbezoek, en al he- 
lemaal niet op hulp bij zelfdoding. Wie niets mankeert, kan geen natuurlijk lijkende dood sterven, en wie niet aan een ongeneeslijke ziekte leidt, heeft geen recht op een zachte dood:

Hij moet natuurlijk zijn, een dood, ook als wij hem een handje geholpen hebben.

Hij moest onbehandelbaar zijn, de patiënt, zelfs wanneer hij dokter Daan is.

De jonge dokter moest kunnen zeggen: ik had hem, hoe dan ook, niets meer te bieden gehad, niets anders dan hem verlossen uit zijn lijden. Alleen dan is het zoals het had moeten gaan. Ik erken dat ik niet alles kan.

En daarna zou de jonge dokter zeggen: ik respecteer mijn voorganger. Hij heeft niemand, zelfs mij niet, belast.

(Ibid.:161-162, cursivering in origineel)

Justus bedekt, om in termen van zijn eigen tweedeling te spreken, zijn hart met zijn verstand. Hij voelt dat hij eigenlijk op deze dag nog bij dokter Daan langs moet gaan om erachter te komen wat er aan de hand is, maar hij wil liever naar Steffie toe. Hij denkt een einde aan het dilemma te kunnen maken door zich te verschuilen achter de codes van zijn beroep. Dokter Daan heeft gezegd dat hij pas de volgende dag hoeft te komen, dokter Daan is niet ziek, en dus hoeft Justus niet bij hem op bezoek te gaan.

Pas aan het eind van het verhaal, als het noodlot zich voltrokken heeft, geeft Justus toe dat hij al die tijd heeft geweten dat hij in alle opzichten en in alle gevallen verkeerd gehandeld heeft. Dan beseft hij dat hij wist dat dokter Daan sterven wilde, niet alleen omdat het 'koor' van vrouwen hem daarvoor gewaarschuwd heeft, maar omdat hij het zelf vermoedde. $\mathrm{Hij}$ is, zegt hij aan het slot van zijn verhaal, oneerlijk geweest tegenover zichzelf. Hij heeft zijn gevoel laten overmeesteren door zijn verstand; hij zat gevangen in een paradoxale beweging. Dat veroorzaakte een bijna ondraaglijke spanning:

Ik moet het begrepen hebben, van het eerste ogenblik af aan, toen het tot me doordrong dat hij me niet vandaag, maar morgen wilde zien. Ik heb het beseft, met het deel van mijn hart dat, zodra het begrijpt, met man en macht wordt aangevallen door alle andere delen. Machtige delen zijn dat, want ze hebben bijwoorbeeld gezworen dat ik altijd zal doen wat binnen mijn vermogen ligt. Ze beschikken over het grote, vitale wapen. De subiete ontkenning. De bliksem- 
snelle verduistering. De volstrekte eis: niemand die niets mankeert mag dood. En wie dood wil mankeert niets.

Ik mocht niet denken wat ik ogenblikkelijk begrepen moet hebben.

(Ibid.134)

Hier wordt de tragiek van het verhaal zichtbaar. Justus doet iets dat begrijpelijk is, maar dat desondanks niet door de beugel kan. Bovendien negeert hij willens en wetens alle signalen van dokter Daans voornemen: de onthulling van het geheim achter de kruisjes is een van die signalen. Dat signaal kun je nog onduidelijk noemen. Andere zijn dat niet. Voordat Justus zijn visites gaat maken, komt zijn vrouw in de praktijk langs. Ook zij wille bij dokter Daan op bezoek gaan, maar ook voor haar heeft hij niet opengedaan. Zij is net zo ongerust als Steffie, en herinnert Justus eraan dat de volgende dag de sterfdag van Daans vrouw is.

Vanaf dat moment ontvouwt zich een nieuw probleem. Justus probeert niet alleen zijn groeiende ongerustheid te onderdrukken, hij probeert ook de samenhang te ontkennen die tussen hem, dokter Daan, Steffie, Hilde en eigenlijk alle andere patiënten bestaat. Ook dat doet hij met behulp van zuiver rationele overwegingen. Hilde is zijn vrouw en hun relatie is niet slecht. Ze is wel ongelijk, redeneert hij, omdat haar vader Justus het geld voor de aankoop van de praktijk geleend heeft. Met die gedachte voorziet Justus zichzelf ook woor zijn overspel van een rationeel excuus: echte gelijkheid en liefde kan hij alleen vinden in zijn relatie met Steffie, omdat hij haar niets verschuldigd is. En wat zijn verhouding tot dokter Daan betreft: dokter Daan is zijn voorganger en als zodanig te respecteren, maar meer niet. Als mevrouw Sleutel dokter Daan wil spreken, zegt Justus dat hij in dat geval niet langer haar huisarts zijn kan. Justus is de professioneel die begrip heeft voor de gevoelens van de uitzichtloos en ondraaglijk lijdende mevrouw Sleutel en die van haar man en kinderen. Hij vindt het geen probleem haar, als en wanneer ze dat wil, een extra dosis morfine te geven. Verder gat hij niet. De rest van haar problemen en die van haar gezin gaat hem niet aan. Als arts hoort hij afstand te bewaren. Maar als hij ziet dat Daan ook op de patiëntenkaart van mevrouw Sleutel een paar kruisjes heeft gezet, laat hij zijn professionele houding even varen. Op het moment dat zijn emotie de overhand krijgtjaloezie speelt hem parten als hij begrijpt hoe belangrijk dokter Daan voor zijn patiënten was - beseft hij dat hij een macht in handen krijgt die in feite te groot voor hem is. Ook in dit geval beseft hij dat hij zich een goddelijke macht aanmeet. Op dit moment erkent hij zelfs dat hij iemand ten onrechte aanmoedigt over haar eigen leven te beschikken, en dat hij daarmee het noodlot tart: 
Ik keek naar het kruis dat boven haar bed hing.

U hebt bestaan, God, omdat dit bestaat, dit ogenblik.

Een vrouw die de overmacht aanvaarden moet. $U$ was er soms, voor sommigen, en u was God, en u was daar waar de dokter nu belooft uw plannetje vóór te zijn.

Ik kan alleen maar stillen, en daarna verpletterd van noodlottigheid zijn.

(Ibid.:145)

Onmiddellijk daarna geeft hij echter weer toe aan zijn behoefte om zuiver rationeel te denken en te handelen. Ondanks alle waarschuwingen aangaande de toestand van dokter Daan, werkt hij zijn visitelijstie af en gaat op de afgesproken tijd bij Steffie langs. Ze is er niet, maar komt na een paar minuten aanrennen - ze is heel toevallig Hilde en haar dochtertje op straat tegengekomen. Ze geeft Justus te kennen dat aan hun relatie een einde gekomen is. Nu ze zijn vrouw heeft gezien, is het alsof er een taboe ontstaan is, zegt ze, of in elk geval bekrachtigd wordt. Steffie maakt Justus nogmaals duidelijk hoezeer ze zich zorgen maakt over dokter Daan. Ze vertelt hem ook over haar relatie met dokter Daan. Justus ziet vervolgens dat er een lange rij kruisjes op haar kaart staat.

Daarna onderneemt Justus een halfhartige poging om dokter Daan alsnog te spreken. Dat leidt tot een volgend drama. In zijn bezorgdheid om Steffie en twijfelend over hoe hij zich gedragen moet tegenover dokter Daan, negeert hij 's avonds de dringende oproep van de moeder van het kind met meningitis. Justus' pogingen gevoel en verstand van elkaar los te maken hebben op dat moment niet een, maar meerdere drama"s veroorzaakt. Justus heeft de dood als een oplossing beschouwd - uit jaloezie en omdat hij als arts zo denken kan en mag. Hij heeft geprobeerd zijn geweten te sussen met louter rationele argumenten. Tegelijkertijd beseft hij dat hij hoe dan ook medeplichtig is aan de dood van dokter Daan. Hij kan zichzelf weliswaar voorhouden dat het dokter Daans wens was te sterven en dat hij, Justus, eigenlijk van niets wist, maar ook dat is een rationalisatie, een verklaring achteraf.

Uit de strijd tussen verstand en gevoel komt Justus als verliezer naar voren. Aan het eind van de tweede dag is zijn huwelijk kapot, zijn relatie met Steffie verbroken en zijn voorganger dood. Zijn patiënten hebben hun vertrouwen in hem verloren. Hij heeft alle voortekenen genegeerd en zich vol overmoed overgegeven aan zijn vermeende recht op beschikking van de levens van zijn patiënten.

Als Justus vol schaamte Heimwou ontvlucht is en zich in zijn boot verstopt heeft, schrijft hij de gebeurtenissen van de afgelopen twee dagen op. Pas dan wordt hem duidelijk dat er een samenhang bestaat tus- 
sen alles wat hij gedaan en niet gedaan heeft tijdens die noodlottige twee dagen. Achteraf beseft hij dat hij niet zelf heeft beschikt over zijn leven, noch over dat van anderen. Hij erkent dat hij geen inzicht heeft in de loop der dingen.

Wat hij pas begrijpt als hij schrijft, is wat hij op de boot in een roman leest: 'wij [bestaan] alleen voor zover we samenhangen met anderen.' (Ibid.:197) Dankzij die zin begrijpt hij dat in de ontkenning van zijn relatie met zijn vrouw, zijn patiënten en dokter Daan de bevestiging van die relatie ligt. Die ontkenning heeft hem in moeilijkheden gebracht. $\mathrm{Zij}$ heeft hem, hoewel hij steeds dacht als de perfecte arts te handelen, ervan afgehouden te doen wat hij als arts hoorde te doen. Zijn patiënten heeft hij niet kunnen troosten, dokter Daan heeft hij niet kunnen helpen en hij heeft een ernstig ziek kind en diens ouders aan hun lot overgelaten. Bovendien heeft hij, door zich nadrukkelijk als opvolger van dokter Daan op te stellen, vermeden oog in oog met dokter Daan te staan. Daardoor heeft hij voorkomen dat hij geconfronteerd werd met de vraag wat je moet doen als je weet dat iemand dood wil. Maar ook wat dat betreft heeft hij niet aan zijn lot kunnen ontkomen: hij wist, ook al wist hij officieel niets, van dokter Daans plannen. Daarom is hij hoe dan ook medeplichtig aan zijn dood.

'Ik ben terwijl ik dit alles opschreef,' zegt Justus, 'gaan begrijpen datiemand die van een mens het handelen beschrijft, ondoordringbaar is [...].'(Ibid.:16o) Waarom dat zo is, weet hij niet - het is een raadsel. Maar uiteindelijk, stelt hij, worden we doorzien:

Uiteindelijk worden we doorzien, of laat ik zeggen: uiteindelijk geloven we dat er meer van ons te weten valt dan wij van onszelf weten. Dat maakt ons bang en groot. Zelfs de koning in de hoogste slottoren, de kapitein in de stormachtigste stuurhut, de dokter aan het verste eind van zijn praktijk, wordt doorzien. Er is altijd iets wat. zij niet kennen, altijd is het web groter dan de spin die het betreedt. (lbid.)

Alles wat Justus bedacht om te ontkomen aan zijn lot, heeft zich tegen hem gekeerd. Door de gebeurtenissen van achtentwintig en negenentwintig maart op te schrijven, begint hij te begrijpen wat er gebeurd is. Hij begrijpt de tragiek van zijn bestaan. Hij ziet in dat hij steeds ten onrechte geprobeerd heeft te denken dat hij zijn leven in de hand had, terwijl hij in werkelijkheid gestuurd werd door anderen, vooral door dokter Daan. Zijn keurig in verschillende compartimenten ingedeeld leven zijn bestaan als echtgenoot en vader enerzijds en als arts anderzijds, zijn verhouding met Steffie, die naar hij meent niets met zijn relatie tot zijn 
vrouw te maken heeft, de afstand tot zijn patiënten en tot dokter Daan blijkt in werkelijkheid een weefsel van samenhangen te zijn, dat gekleurd wordt door emoties en bestuurd door bovennatuurlijke machten.

Voor Justus" patiènten geldt dat ze net zo weinig over hun eigen leven beschikken als Justus over het zijne. Het idee van zelfbeschikking, zo blijkt uit deze lezing van Ons mankeert niets als een tragedie, is een illusie. Al onze beslissingen worden beinvloed door de meningen en de handelingen van anderen, zelfs als we denken dat we volledig zelfstandig een beslissing hebben genomen. Justus' patiënten die om euthanasie vragen, zijn volkomen afhankelijk van zijn oordeel en zijn besluit. Patiënt Galesloot heeft te kennen gegeven dat hij door euthanasie sterven wil, maar hij is uiteindelijk niet alleen afhankelijk van het oordeel van de ziekenhuisartsen, maar ook van het rooster van de twee praktiserende huisartsen in Heimwou. En mevrouw Sleutel denkt weliswaar dat Justus haar kant kiest en haar op haar aandringen belooft haar te helpen bij het sterven, maar hij zal dat alleen doen omdat de ziekenhuisartsen haar opgegeven hebben. Van zelfbeschikking is in al deze gevallen geen sprake.

Alleen dokter Daan lijkt weloverwogen en geheel vrijwillig een einde te maken aan zijn leven. Maar hij kan en wil zichzelf niet doden zonder de indirecte hulp van Justus. Daardoor beschikt dokter Daan over het leven van een ander: hij maakt Justus medeplichtig aan zijn zelfgekozen dood. Dokter Daan grijpt niet alleen in zijn eigen leven in, maar ook in dat van alle mensen die hem liefhebben en in dat van Justus. Met betrekking tor Justus lijkt hij de rol van een straffende god aangenomen te hebben. Hij lijkt met zijn zelfgekozen dood niet alleen zichzelf, maar ook Justus te straffen voor diens hoogmoed, zijn overtredingen van verschillende geboden en verboden en voor eigenzinnig handelen.

Maar wat moeten we denken van de verhouding tussen dokter Daan en zijn patiënten? Wat moeten we van zijn aanrakingen vinden? Hoewel die aanrakingen waarschijnlijk niet tegen de zin van de patiënten hebben plaatsgevonden, kun je stellen dat Daan zijn vrouwellijke patiënten door zijn aanrakingen van hem afhankelijk maakt. Ze beschouwen hem in elk geval allemaal als hun held, hun leidsman, voor wie ze door het vuur gaan. De slager van Heimwou, wiens zieke vrouw Justus bezoekt, vertelt dat hij tegen de invloed van dokter Daan niet opgewassen is. 'Weet $u_{\text {,' }}$ zegt hij tegen Justus, "van sommige mensen zeggen ze: hij is als een vader. Als man heb je daar niet zo'n boodschap aan. Begrijpt u?' (Ibid.:85) Hoe zouden Daans vrouwelijke patiënten tot een zelfstandige en weloverwogen beslissing kunnen komen, als Daan hun vertellen zou dat ze maar beter sterven kunnen?

En wat betekent in Daans eigen geval 'vrijwillig' en 'weloverwogen'? Daan kan niet langer leven met het gevoel dat hij zijn vrouw vermoord 
heeft. Strikt logisch gezien is er niets aan de hand. Zijn vrouw wilde sterven. omdat ze de dood van haar zoon niet verwerken kon. Dokter Daan hoeft zich dus niet schuldig te voelen. Toch doet hij dat. Aan Steffie vertelt hij dat hij niet verder leven kan. Met weloverwogenheid heeft zijn beslissing zichzelf te doden blijkbaar niets te maken. Schuldgevoelens en eenzaamheid spelen hier een grotere rol dan zuiver rationele overwegingen. Bovendien is het de vraag in hoeverre we zijn voornemen vrijwillig kunnen noemen. Na de dood van zijn vrouw ziet hij geen andere uitweg dan zichzelf van het leven te beroven - hij voelt zich gedwongen zichzelf te doden. De vrouwen in zijn omgeving voelen dat haarscherp aan.

Van weloverwogenheid en zelfbeschikking, zo lijkt Ons mankeert niets te leren, kan inzake euthanasie en hulp bij zelfdoding geen sprake zijn, zelfs niet bij dokter Daan. Ten eerste nemen patiënten nooit alléén de beslissing om dood te gaan - zij zijn immers afhankelijk van de arts die hen helpt. Ten tweede veronderstelt het begrip 'weloverwogen' dat de bij euthanasie betrokkenen op zuiver rationele wijze over de dood kunnen beslissen. Uit de voorbeelden van Justus en Daan blijkt dat gevoel en verstand niet van elkaar gescheiden kunnen worden. Alle zogenaamd zuiver rationele beslissingen worden gevoed door emoties als liefde, jaloezie, angst of eenzaamheid. Dat geldt voor artsen niet minder dan voor patiënten. De tweedeling in gevoel en verstand en het verlangen naar zelfbeschikking eindigen in deze roman steeds tragisch.

Door het lot, laat deze tragedie zien, zijn we met elkaar verbonden; door het lot zijn we tot elkaar veroordeeld. Het lot makt dat in onze levens van zelfbeschikking geen sprake kan zijn. Justus en dokter Daan lijken volkomen autonoom te handelen. In werkelijkheid zijn ze tragische personages, die ellkaar de afgrond insleuren. Justus helpt dokter Daan de hand aan zichzelf te slaan door te doen alsof hij niet begrijpt wat dokter Daan van plan is. Als de held in een Griekse tragedie kan hij echter alleen maar foute beslissingen nemen. Wanneer hij een halfhartige poging onderneemt om vóor het afgesproken tijdstip bij dokter Daan langs te gaan, moet hij zich wel terugtrekken, omdat hij anders Daan en Steffie stoort. Dat zou niet alleen voor hem pijnlijk zijn, maar ook voor dokter Daan en Steffie. Dat zou Justus" verhouding met Steffie nog slechter maken, en dat zou Justus nog ongelukkiger maken dan hij al is. Hoe kan een mens in zo'n situatie weloverwogen handelen?

\section{Slotsom}

Een arts die euthanasie toepast, moet volgens de wet de overtuiging hebben gekregen dat er sprake was van een vrijwillig en weloverwogen verzoek van de betrokken patiënt.

Als we Ons mankeert niets alls een tragedie lezen, zien we dat daarin 
vrijwillige en weloverwogen euthanasieverzoeken nauwelijks voorkomen. Van vrijwilligheid en weloverwogenheid, kun je stellen ${ }_{k}$ is in de roman nauwelijks sprake. De oude meneer Galesloot heeft te kennen gegeven dat hij sterven wil als hij ongeneeslijk ziek verklaard wordt, maar hij krijgt niet de kans zelf het tijdstip van zijn dood te bepalen. Hij sterft wanneer het de artsen het beste uitkomt. Dat geldt ook voor mevrouw Sleutel. Haar verzoek lijkt vrijwillig en weloverwogen, maar wie er in dit gevall werkelijk beslist, is Justus. Hij belooft haar een 'zachte dood', niet zozeer omdat zij daar om vraagt, maar orndat de artsen in het ziekenhuis haar officieel opgegeven hebben. Evelien Daans dood kun je vrijwillig noemen, maar nauwelijks weloverwogen. Evelien Daan was, zo vertelt Steffie, zwaar depressief toen ze haar man vroeg haar bij haar zelfdoding te helpen.

Ook Justus en dokter Daan lijken steeds weloverwogen en vrijwillig te handelen, maar doen dat niet. De verhouding tussen dokter Daan en zijn patiënten is allesbehalve rationeel. En wat zijn dood betreft: die zou je vrijwillig kunnen noemen, en zelfs weloverwogen. Maar als we dokter Daan als een tragisch personage beschouwen, moeten we vaststellen dat ook in zijn geval geen sprake is van vrijwilligheid en weloverwogenheid. Zijn vrouw heeft hij bij haar zelfgekozen dood geholpen, omdat hij haar lijden niet aan kan zien. Omdat hij het verbod op moord heeft overtreden, moet ook hij sterven.

Iustus ten slotte doet voortdurend zijn best gevoel en verstand van elkaar te scheiden, waarbij hij het verstand boven het gevoel stelt. Met zijn patiënten probeert hij zo rationeel mogelijk om te gaan. Hij laat zich leiden door regels en formaliteiten, zelfs wanneer hij beseft dat hij dat maar beter niet kan doen. Daardoor creëert hij een bijna onoverbrugbare afstand tussen zichzelf en zijn patiënten. Hij vindt zijn eigen oordeel het belangrijkst. Bovendien denkt hij dat hij over leven en dood van anderen kan oordelen. Wanneer een patiënt door hem en zijn collega's ongeneeslijk ziek verklaard is, past hij euthanasie toe, soms, zoals in het geval van meneer Galesloot, zelfs zonder uitdrukkelijk, direct verzoek van de patiënt. Ook in zijn persoonlijk leven denkt Justus te handelen volgens strikt rationele overwegingen. Doordat hij zich voortdurend concentreert op strikt rationele argumenten, merkt hij niet hoezeer zijn leven bepaald wordt door zijn verhouding met anderen. Uit jaloezie en schaamte doet hij nauwelijks iets om de zelfdoding van dokter Daan te verhinderen. Daardoor maakt ook hij zich schuldig aan hulp bij zelfdoding, en komt hij ten val. Hij kan zijn lot niet ontlopen. 
Als arts wordt Justus voortdurend geconfronteerd met de vraag die in de ethanasiediscussie net zo'n belangrijke rol speelt als de vraag naar de mogelijkheid van beschikking en zelfbeschikking: wanneer is het lijden van een patiënt uitzichtloos en ondraaglijk geworden?

In zijn essays stelt Otten dat die vraag niet beantwoord kan worden. Lijden, zegt hij, is niet iets dat je aan de hand van abstracte en algemene kenmerken kunt meten. De mate warin een zieke lijdt, is altijd afhankelijk van de situatie waarin die zich bevindt. Wanneer abstracte begrippen als 'ondraaglijk' en 'uitzichtloos' gebruikt worden als criterium voor het inwilligen van een euthanasieverzoek, zullen artsen het lijden van een individuele patiënt meten aan die abstracte en algemene begrippen, in plaats dat ze de persoonlijke beleving van het lijden als matstaf nemen. De begrippen 'ondraaglijk' en 'uitzichtloos' zullen, anders uitgedrukt, over de werkelijkheid gelegd worden, en er niet uit voortkomen. Een gevolg daarvan is dat iedereen die officieel uitzichtloos en ondraaglijk lijdt, bijna verplicht zal zijn om euthanasie te vragen. (Otten 1995a, 1995b) Ten slotte gaat de discussie over de legalisering van euthanasie volgens Otten aan de betekenis van het lijden voorbij. Lijden, stelt hij, is onlosmakelijk verbonden met het menselijk leven en heeft een bepaalde zin. (Otten 1995a)

In Ons mankeert niets komt de complexiteit van het menselijk lijden tot uitdrukking: de onmogelijkheid lijden te definiëren, de verwevenheid van lichamelijk en geestelijk lijden en de onderlinge betrokkenheid van patiënten, de mensen in hun omgeving en hun artsen. Justus wordt drie keer expliciet geconfronteerd met de vraag naar de ondraaglijkheid en de uitzichtloosheid van lijden. Al die keren moet hij bepalen of dat lijden van dien aard is, dat hij er een einde aan mag maken. In het eerste geval reageert hij precies zoals een arts volgens Otten niet zou mogen reageren: hij laat de ratio prevaleren. Als Justus op maandagochtend hoort dat de oude meneer Galesloot gestorven is, reageert hij volstrekt rationeel: de patiënt beschouwt hij in de eerste plaats als een medisch geval. Meneer Galesloot is via Justus in het ziekenhuis beland, en was een tijd aan het oog van Justus onttrokken. Patiënt Galesloot, zegt Justus, is daardoor niet meer geworden dan een herinnering: 'Een radeloze, tandeloze blik, geworpen tijdens de laatste keer dat we hem thuis bezochten tussen twee operaties in, om met hem te bespreken wat de specialist bedoelde toen die zich in raadseltaal van de wisse afloop had gehuld." (Otten 1994d:21) Nadat Galesloot door de artsen in het ziekenhuis opgegeven is, is hij naar huis teruggekeerd. Daar is hij weer onder de hoede van Justus gekomen. Justus heeft hem beloofd dat hij ervoor zal zorgen 
dat hij, Galesloot, zo min mogelijk pijn zal lijden. Toen meneer Gallesloot doorhad dat hij niet meer zou genezen, had hij Justus om euthanasie verzocht, "maar toen hij bijna niet meer bestond van verdoofde pijn en verdoofde angst, had hij het verzoek niet herhaald'. (Ibid.:22) Toch had Justus hem een zware dosis pijnstiller gegeven - een te zware dosis, vertelt Justus zelf. Daarna was het weekend geworden en had Justus geen dienst gehad. Meneer Galesloot is uiteindelijk gestorven onder de hoede van dokter Verdurmen, Justus' vervanger. Justus zal de Verklaring van Overlijden tekenen en vermelden dat de patiënt is overleden als gevolg van een natuurlijke oorzaak. Het is niet helemaal duidelijk wie Galesloot heeft laten sterven, Justus of zijn vervanger:

Het laatste wat ik, voor het weekend, met Galesloot had gedaan was hem zoveel pijnstiller inspuiten dat hij buiten bewustzijn raakte. Hij had zijn verzoek nooit herhaald, toch heb ik hem een zware, al te zware dosis ingespoten. Die dosis zou ik, als hij inmiddels niet gestorven was, vandaag vergroot hebben. En ook dan had ik de Verklaring zo ingevuld als ik hem nu zou invullen.

(Ibid.:23-24)

Justus vindt het niet belangrijk wie uiteindelijk verantwoordelijk is voor meneer Galesloots dood. De oude man was in zijn ogen een duidelijk geval. Hij leed volgens de officiële criteria uitzichtloos en ondraaglijk. Hij had zijn arts laten weten dat hij een zachte dood sterven wilde. De beslissing hem te laten sterven was daarom makkelijk genomen. Als Justus en Verdurmen het geval met elkaar bespreken, zal Justus zijn collega niet naar de ware oorzaak van Galesloots dood vragen. Beide artsen menen te weten dat ze juist gehandeld hebben door het stervensproces te bespoedigen. Wie zo lijdt als Galesloot moet volgens alle rationele overwegingen gedood worden. De beslissing Galesloot een dodelijke dosis pijnstiller toe te dienen, lijkt extra makkelijk omdat Justus geen enkele emotionele band met deze patiënt heeft. Hij weet uiteindelijk nauwelijks nog wie meneer Galesloot is.

Het tweede geval is minder eenduidig voor Justus. De laatste mensen die Justus op zijn spreekuur van maandagochtend ziet, zijn de man en de dochters van mevrouw Sleutel. Mevrouw Sleutel heeft kanker. Ze heeft nog maar één nier, en ze heeft uitzaaiingen. De ziekenhuisartsen hebben ook haar opgegeven en naar huis gestuurd. De kinderen weten dat hun moeder ongeneeslijk ziek is, maar in eerste instantie proberen ze Justus ervan te overtuigen dat het veel beter met hun moeder gaat dan je verwachten zou. Moeder heeft weer trek in eten, zeggen ze. Ze ziet er goed uit en ze voelt zich beter dan in jaren. Justus probeert het gesprek op iets 
anders te brengen. Hij weet dat mevrouw Sleutel zich zo goed voelt, omdat ze een bloedtransfusie gehad heeft. Hij weet ook dat het binnen enkele uren weer slecht met haar zal gaan, en dat ze officieel niet in aanmerking komt voor een nieuwe transfusie. De volgende dag krijgt Justus een telefoontje van de man van mevrouw Sleutel. Meneer Sleutel meldt dat zijn vrouw dood wil: 'Ze zegt alleen maar ik will dood.' (Ibid.:139) Het probleem is dat mevrouw Sleutel door dokter Daan geholpen wil worden, niet door Justus.

Op dit moment gaan allerlei emoties een rol spelen. Justus raakt geirriteerd. Mevrouw Sleutel is zijn patiènte en niet langer die van dokter Daan. Justus voelt zich door de wens van mevrouw Sleutel in zijn autoriteit aangetast. Op persoonlijk gebied zijn er andere zaken die hem een slecht humeur bezorgen. Steffie heeft aangekondigd dat ze haar verhouding met hem wil verbreken, omdat ze zijn vrouw en dochtertje ontmoet heeft. Ook maakt ze zich grote zorgen om dokter Daan, die haar die dag niet heeft willen zien. Voordat Justus naar mevrouw Sleutel vertrekt, belt hij Steffie. Die antwoordt niet met haar naam, maar met de vraag 'Ben jij het, Berend?' (Ibid.:140) Justus raakt in verwarring. Hij weet dat als hij naar Steffie gaat, hij niet alleen haar leven weer binnenstapt, maar ook dat van dokter Daan.

Wanneer Justus bij mevrouw Sleutel aankomt, weigert die met hem te praten. Ze wil maar één ding: dokter Daan zien. Dit compliceert de zaak. Juridisch en medisch gezien zijn er geen problemen. Mevrouw Sleutel is opgegeven door de artsen van het ziekenhuis. Haar lichamelijk lijden is officieel als uitzichtloos en ondraaglijk bestempeld. Ze heeft zelf al gezegd dat ze niet langer wil leven. Justus hoeft haar dus alleen maar een fatale injectie te geven, zodra ze erom vraagt of wanneer hij meent dat het juiste moment is gekomen. Maar wanneer mevrouw Sleutel vasthoudt aan haar eis dokter Daan te zien, begrijpt Justus dat haar klachten niet alleen lichamelijk zijn. Heel even begrijpt hij de nietigheid van zijn hulp. Met een simpel spuitje zal hij God vóór zijn, niet meer en niet minder. De vanzelfsprekendheid waarmee Justus eerder aan meneer Galesloot de fatale dosis pijnstiller gegeven heeft, lijkt verdwenen. Als Justus ten slotte besluit mevrouw Sleutel bij het sterven te helpen, spelen verschillende emoties een rol. Hij belooft haar uit haar lijden te verlossen, niet alleen omdat hij medelijden met haar heeft, maar ook omdat hij zich door haar vraag naar dokter Daan in zijn beroepseer aangetast voelt. Hij wil duidelijk maken dat niet Berend Daan, maar hijzelf de dokter is die ze om hulp vragen moet. En misschien wil hij met zijn toezegging ook bewijzen dat hij ondanks alle emotionele problemen met Steffie het hoofd koel houdt en op een professionele manier beslissingen nemen kan. Met het lichamelijke lijden van mevrouw Sleutel heeft Justus' besluit om euthanasie 
toe te passen ten slotte weinig meer te maken.

In het derde geval waarin iemand te kennen geeft dat hij sterven wil, is er van aantoonbaar uitzichtloos en ondraaglijk lijden helemaal geen sprake. Dokter Daan wil dood, ook al mankeert hij niets. Justus" professionele houding is nu helemaal verdwenen. Hij weet zich geen raad met Daans doodswens. Daan valt precies in die categorie patiënten die Justus vreest: de patiënten die van hem verlangen dat hij de eed van Hippocrates verbreekt. 'Ik bedoel niet de zieke wiens dagen geteld zijn, maar de gezonde man of vrouw die van mij en mijn Eed een groteske zou maken omdat hij op klaarlichte dag vastberaden was niet meer te willen leven,' zegt hij. (Ibid.:20) Dokter Daan lijdt, maar zijn lijden is onmeetbaar, onaantoonbaar en daarom voor Justus onbegrijpelijk. Nu laat Justus zijn emoties de vrije baan. Uit liefde voor Steffie besluit hij bij dokter Daan langs te gaan. Op dat moment, begrijpt hij later, laat hij alle verstand varen: hij neemt een onprofessionele beslissing, een beslissing waarvan hij weet dat ze noodlottig is. "In twee seconden kun je alles overwogen hebben wat er te overwegen valt,' zegt hij. "Er is geen tragedie, zelfs de ingewikkeldste Griekse niet, die niet in twee seconden, van begin tot het eind, met éen gedachte te overspannen is.' (Ibid.:140)

Tegen beter weten in probeert Justus een rationele verklaring te vinden voor zowel zijn eigen handelen als dokter Daans doodswens. $\mathrm{Na}$ het bezoek aan mevrouw Sleutel gaat hij naar Steffie, zichzelf wijsmakend dat hij van haar alleen maar wil horen of er een juridisch aanvaardbare reden bestaat voor dokter Daans doodswens:

Ik moest het begrijpen, en dokter Daans doodswens logisch en onverbiddelijk laten voortvloeien uit alles wat Steffie mij nu ging vertellen. En als ik zijn doodswens begreep, zou ik zijn dood aanvaarden.

(Ibid.:161)

In vergelijking met het lijden van dokter Daan leek het lijden van meneer Galesloot zo aangenaam eenduidig. Justus hoefde alleen maar de eerste klacht te behandelen. Die klacht stond als het ware voorgedrukt op het ziekenhuisrapport: Galesloot is ongeneeslijk ziek verklaard. Zijn euthanasie wordt volgens de regels van de wet uitgevoerd. Justus is er niet emotioneel bij betrokken. Hij maakt een licht cynische opmerking over de macht die hij en zijn collega's hebben, en daarmee is de zaak afgedaan. Voor Justus en zijn collega's is het daarom volkomen normaal en volledig probleemloos om patiënt Galesloot een fatale dosis pijnstiller toe te dienen. Ze hoeven er niet eens meer over te praten, niet met elkaar, maar ook niet met de patiënt. Euthanasie lijkt in deze situatie logisch en zelfs natuurlijk. 
Maar zo eenvoudig is zelfs het 'geval Galesloot' niet. Want wat betekent hier uitzichtloos en ondraaglijk? Wie heeft Galesloots lijden gemeten? Niet Justus zelf, maar de anonieme artsen in het ziekenhuis. Justus late zich leiden door een schriftelijke verklaring, niet door Galesloots bevinden en wensen. Dat Galesloot heeft laat weten dat hij geen onwaardige dood wilde sterven is mooi meegenomen, maar dat zegt nog niets over de mate van zijn lijden. Of en hoe Galesloot werkelijk lijdt, weet Justus niet. Sterker nog, hij heeft zijn patiënt naar aanleiding van de verklaring van de ziekenhuisartsen al platgespoten voordat die zelfs nog maar duidelijk kon maken dat hij ondraaglijk leed. Zo blijkt dat een arts met de eis van 'uitzichtloos en ondraaglijk lijden' alle kanten op kan: hij kan zich llaten leiden door de uitspraken van zijn patiënt, maar ook door zijn eigen oordeel en zelfs door dat van anderen. Machtsmisbruik wordt door de officiële bestempeling van Galesloots lijden als uitzichtloos en. ondraaglijk eerder bevorderd dan vermeden. Want Justus" beslissing om de dood van Galesloot niet aanhangig te maken bij justitie is wel degelijk ook door emoties gestuurd. Door zich 'als een god" te gedragen, bevestigt hij zijn positie als arts en bezweert hij zijn angst dat men hem als onvolwaardig opvolger van dokter Daan beschouwt.

De doodsverlangens van mevrouw Sleutel en dokter Daan laten zien dat lijden nooit alleen zuiver lichamelijk is en dus in feite onmogelijk gemeten kan worden. Mevrouw Sleutel en dokter Daan confronteren Justus met 'de tweede klacht'. Hun doodswensen hebben slechts ten dele of niets te maken met uitzichtloos en ondraaglijk lijden. Mevrouw Sleutel is bang en verlangt naar de geruststellende woorden van dokter Daan. Dokter Daan wil sterven, omdat zijn vrouw en zijn zoon dood zijn. Justus weet niet hoe hij om moet gaan met dergelijk ondefinieerbaar lijden. Hij weet om te beginnen niet hoe hij het lijden van Daan classificeren moet. De enige logische reden die hij voor diens doodswens kan bedenken, is dat dokter Daan sterven moet, omdat hij zijn vrouw geholpen heeft zichzelf om te brengen. Die reden voldoet echter niet. Als behandelaar van eerste klachten kan Justus niet accepteren dat dokter Daan gewoon dood wil, omdat hij niet verder leven wil. 'Het mag niet waar zijn dat dood willen te begrijpen is,' zegt hij. (Ibid.:15o)

Ook in het geval van dokter Daan spelen, anders dan Justus wil geloven, Justus' emoties een doorslaggevende rol. Hij doet uit verwarring over Daans doodswens en uit jaloezie te weinig om zijn voorganger van diens voornemen af te brengen. Daarom probeert hij telkens weer zijn beslissingen te rationaliseren en zijn gedrag met abstracte uitspraken goed te praten. Dat maakt hem niet alleen onzeker, het brengt hem ook in meer problemen dan hij vermoeden kon. De moeder van het kind met meningitis ziet hoe Justus 's nachts Steffie bij het huis van dokter Daan 
afzet. Wat ze gezien heeft, zal ze later tegen hem gebruiken. Pas nadat Justus het lichaam van dokter Daan gevonden heeft, realiseert hij zich dat hij als mens machteloos staat tegenover het lot. Dan pas geeft hij toe dat lijden niet classificeerbaar en niet meetbaar is. Zijn eigen lijden ten slotte - zijn schuldgevoelens, de pijn van het verlies van zijn geliefde en zijn falen als arts - onthult de essentie van zijn bestaan als tragisch personage. Hij heeft dingen gedaan die begrijpelijk zijn, maar die niet mogen. Je mag je vrouw niet bedriegen en je mag een ander niet doden. Justus trekt zich terug uit zijn praktijk en het leven met zijn vrouw en kinderen, en schrijft zijn schuldbekentenis. Ook zijn eigen lijden is onmeetbaar geworden.

\section{En dokter Daan?}

Dokter Daan maakt zich schuldig aan wat Otten de taboeisering van het lijden noemt. Dokter Daan heeft zijn vrouw geholpen te sterven, omdat het leven voor haar geen zin meer had. Maar waarom zou dat een reden zijn om een einde aan je leven te maken? De verklaring die het koor der vrouwen in deze roman voor de zelfdoding van Evelien Daan geven, klinkt te abstract, alsof je de zinloosheid van een leven meten kunt en bij een al te hoge graad zinloosheid jezelf maar beter naar een andere wereld helpen kunt. Je kunt ook stellen dat Evelien Daan het lijden als zinloos beschouwde, omdat ze niet accepteren wilde dat de dood bij het leven hoort. In die zin heeft ze precies gedaan wat Otten in zijn essays laakt: ze heeft de concrete werkelijkheid ondergeschikt gemaakt aan een idee. Ze heeft ontkend dat lijden bij het leven hoort en deel uitmaakt van de tragiek van ons bestaan. Dokter Daan heeft haar in die denkbeelden gesteund.

Hier zien we precies diezelfde onvermijdelijke, fatale vermenging van zuiver rationele verklaringen met al dan niet bewuste emoties, die we ook steeds bij Justus tegenkomen: we krijgen steeds te horen dat dokter Daan het lijden van zijn vrouw niet langer kon aanzien. Maar wie zegt ons dat hij niet domweg zijn vrouw uit de weg wilde ruimen, om de weg vrij te maken voor zijn jonge vriendin? Wie zal ons zeggen dat de hulp bij zelfdoding in dit geval niet domweg moord was?

Zo bezien kun je ook dokter Daans zelfdoding op twee verschillende manieren interpreteren. Hij wilde sterven, kun je zeggen, omdat hij niet zonder zijn vrouw kon leven. De dood van Evelien heeft zijn leven zinloos gemaakt. Maar je kunt ook stellen dat hij, net als Evelien, geen zin in het lijden ontdekken kan, en dat hij zich laat leiden door een louter abstract idee. Daarbij ontkent ook hij hoezeer ook hij met anderen verbonden is. Hij kan zijn lijden niet relativeren door het besef van het verdriet dat hij Steffie door zijn dood bezorgen zal en hij bekommert zich er niet om dat zijn dood Justus' leven radicaal veranderen zal. Hij klampt zich 
vast aan het idee dat het leven geen zin meer heeft, maar dat idee is even klinisch als de verklaring van de ziekenhuisartsen over de ondraaglijkheid en uitzichtloosheid van het lijden van meneer Galesloot. Lijden is een abstractie geworden. In die abstractie drukt zich ook hier weer de hoogmoed uit van mensen die ten onrechte denken dat zij de concrete werkelijkheid aan een abstract idee ondergeschikt maken kunnen. Mensen die zo denken zijn ervan overtuigd dat zij denken en gevoel van elkaar los koppelen kunnen. Zij denken dat zij hun gevoel kunnen temmen met zuivere rationeel denken. Dergelijke mensen denken dat zij alles begrijpen en beheersen kunnen, zelfs de dood, die buitenmenselijke anngelegenheid. Zij denken dat zij het lijden uit het leven bannen kunnen en zelfs moeten. Zulke mensen eigenen zich een macht toe die zij niet hebben mogen en waarmee zij niet kunnen omgaan. Zij ontkennen bovendien dat het leven altijd een tragische component heeft. De gevolgen van deze manier van denken zijn desastreus. Dokter Daan verwoest niet alleen zijn eigen leven, maar ook dat van Justus en van alle mensen die hem liefhebben.

\section{Slotsom}

De tweede zorgvuldigheidseis uit de wet op euthanasie en hulp bij zelfdoding heeft betrekking op het lijden van een patiënt. Een arts die euthanasie toepast of een patiënt bij zelfdoding helpt, wordt niet vervolgd wanneer het lijden van die patiënt uitzichtloos en ondraaglijk verklaard is. Het tragische verhaal over Justus en dokter Daan laat zien dat lijden, precies zoals Otten in zijn essays vaststelt, nooit te vatten is met abstracte begrippen als 'ondraaglijk' en 'uitzichtloos'. Lijden kan niet objectief gemeten worden. Ten eerste $\mathrm{lij}_{\mathrm{i}} \mathrm{t}$ iedereen op zijn of haar eigen manier. Ten tweede is lijden niet eenduidig of gelijkmatig; een patiënt kan de ene dag meer lijden dan de andere of kan in de ene situatie beter omgaan met het lijden dan in de andere. Hoewel het lijden van meneer Galesloot officieel uitzichtloos en ondraaglijk verklaard is, weet Justus niet hoezeer zijn patiënt werkelijk lijdt. Ten derde is lijden altijd zowel lichamelijk als psychisch. Mevrouw Sleutel lijdt minder zodra ze begrijpt dat Justus haar toezegt haar bij het sterven te helpen. Ten vierde beseffen mensen die door middel van euthanasie een einde aan hun lijden willen maken niet dat lijden een bepaalde zin heeft. Toen dokter Daan zijn vrouw hielp, begreep hij niet dat daardoor zijn eigen leven alle betekenis verloor. Als hij zelf een einde aan zijn leven maakt, ontneemt hij de zin aan Steffies bestaan. Ten vijfde reageert een arts die lijden meten moet in de meeste gevallen net zo subjectief op het lijden van een patiënt als de patiënt zelf. De beslissingen van Justus om euthanasie toe te passen zijn in de meeste gevallen emotioneel. Pas achteraf probeert hij een rationele verklaring 
voor zijn beslissingen te vinden. Hij beseft echter maar al te goed dat hij zich in eerste instantie heeft laten leiden door zijn gevoelens. Als we Ons mankeert niets lezen als een tragedie, moeten we vaststellen dat ook die dubbele houding Justus tot een tragisch personage maakt. Hetzelfde geldt voor dokter Daan. Opzettelijk en bewust trotseren de twee artsen het verbod op het doden van een medemens. Door zich een oordeel over het lijden van een ander aan te matigen, eigenen zij zich een macht toe die hun niet toekomt. Beiden kunnen het noodlot niet ontkomen.

\section{Kennis maakt medeplichtig}

De wet op euthanasie en hulp bij zelfdoding eist dat een arts, nadat een patiënt te kennen heeft gegeven dat hij of zij sterven wil, officieel met die patiënt, en met een andere arts over de vooruitzichten van de patiënt spreekt. In zijn essays stelt Otten dat hij elke betrokkenheid bij euthanasie beschouwt als medeplichtigheid aan moord. (Otten 1993a, I995a, 1995d) Dat geldt dus ook voor overleg over euthanasie tussen een arts en een patiënt en tussen artsen onderling. Patiënten maken hun artsen medeplichtig, en de artsen hun collega's. Als we Ons mankeert niets als een tragedie lezen, zien we dat iedereen die op enigerlei wijze te maken heeft met een onnatuurlijke dood, schuldig is aan het overtreden van het taboe op moord en daarvoor gestraft wordt.

Van die medeplichtigheid is in de roman op verschillende manieren sprake. Justus wordt drie keer bij een onnatuurlijke dood betrokken. In het eerste geval - dat van de oude meneer Galesloot - is van consultatie nauwelijks sprake. Justus' vertrouwen in regels en voorschriften en ook zijn vertrouwen in zijn macht als arts komen hier volop in het licht te staan. Patiënt Galesloot heeft één keer om euthanasie verzocht, maar werd daarna te ziek om zijn verzoek te herhalen. 'Daarna was het weekend geworden.' (Otten 1994d:22) De patiënt wordt conform de regels overgedragen aan de waarnemer. Hij sterft waarschijnlijk door een overdosis pijnstiller. Het consult van Justus met Verdurmen verloopt telefonisch en schriftelijk. Veel valt er, menen ze, niet te bespreken. Justus staat nog even stil bij de macht die hij en zijn collega zich hebben aangemeten. Hij vergelijkt zichzelf en zijn collega's met goden die het noodlot kennen. (Ibid.:24) Hij noemt zich "het bezige baasje-op-leven-en-dood". (Ibid.:44) Meer woorden maakt hij er niet aan vuil. Galesloot is een geval uit het boekje, en wordt volgens het boekje behandeld. Hij is gereduceerd tot een archiefkaartje dat Justus uit de kaartenbak verwijdert. Justus zal hoogstens nog een keer aan Galesloot denken wanneer een andere patiënt om euthanasie verzoekt: 
Graag schreef ik nu op dat ik even een heldere, rustige voorstelling had van zijn einde, van de stilte tussen laatste ademhaling en geen ademhaling meer, maar ik legde Galesloot alleen maar opzij, wel wetend dat ik aan hem zou denken bij de volgende patiënt die als opgegeven terug zou keren in mijn praktijk. Zijn einde, zelfs al had ik het niet meegemakkt, zou versmelten met de eindes van anderen - en wie weet was er, tussen deze stapel kaarten, weer zo'n einde op til.

(Ibid.:23)

In dit geval kan Justus zich er makkelijk van overtuigen dat hij niets met de dood van een patiënt te maken heeft. De verantwoordelijkheid daarvoor kan hij zonder problemen afschuiven op zijn collega. Dat denkt hij tenminste. Omdat meneer Galesloot Justus te kennen heeft gegeven dat hij sterven wil wanneer hij ongeneeslijk ziek verklaard wordt, heeft hij Justus medeplichtig gemaakt aan zijn dood.

Mevrouw Sleutel daarentegen wil in het begin niet meewerken. Ze weigert met Justus te praten. Justus zou zich in dit geval dus kunnen terugtrekken en zijn handen in onschuld wassen. Maar Justus raakt geïriteerd, omdat mevrouw Sleutel dokter Daan wil spreken. Een van haar dochters heeft geprobeerd met dokter Daan te praten, maar dat is haar niet gelukt. 'Eén ding,' zegt Justus tegen het gezin, als hij hoort van de pogingen om dokter Daan te spreken te krijgen, 'u hebt mij opgebeld. Ik ben de dokter. Als u een andere dokter wilt, dan thoud ik u niet tegen. Maar als u mij belt, dan ben ik de dokter.' (Ibid.:142)

Justus is niet van plan te praten zolang de patiënte niet meewerkt. Haar verwarring en angst staan een regulier consult in de weg, althans een consult zoals Justus voor ogen staat: een strikt logisch en rationeel gesprek waarin arts en patiënt afstand houden en alleen over de eerste, lichamelijke klacht praten. Mevrouw Sleutel verhindert hem haar eerste klacht te behandelen.

Paradoxaal genoeg wil mevrouw Sleutel niet met Justus over euthanasie praten, omdat hij zich zo duidelijk presenteert alls een afstandelijk, strikt rationeel handelende arts. Met dokter Daan, die zo gevoelvol is, wil ze dat wel. Pas als Justus doet alsof hij zijn professionele houding aflegt, haar aanraakt op een manier die lijkt op de aanraking van dokter Daan en op een persoonlijke manier met haar praat, draait ze bij:

Ik legde mijn handen op haar knieën.

En als ik dood wil, zei ze, fluisterend plotseling.

Het was geen vraag, het was een zwevende zin.

Ze legde met een plofje har gevouwen handen in haar schoot. 
Als u dood wilt, herhaalde ik zo zacht en zo zwevend als ik kon.

Het zinnetje zweefde als een sliertje tabaksrook omhoogen werd een kringetje.

Wilde u daarom dat dokter Daan kwam? vroeg ik, nog altijd onhoorbaar voor de anderen.

Ze sloot haar ogen en zuchtte een seconde lange zucht.

Toen ze haar ogen opende biggelden er twee grote tranen over de wallen onder haar ogen.

Alls het zo ver is ben ik bij u, zei ik. Dat beloof ik.

Ze glimlachte en veegde met een roze mouw haar tranen weg.

Maar nu moet u gaan slapen.

Ze stond op, raadselachtig gedwee.

(Ibid.:144)

Met die belofte maakt Justus zich, zonder dat hij dat voor zichzelf toegeeft, medeplichtig aan moord. Zolang hij zich op zijn medische kennis beroepen kan, is hij in staat eventuele schuldgevoelens weg te praten met ironische opmerkingen, rationele verklaringen en zelfspot. In gevallen als die van meneer Galesloot en mevrouw Sleutel lijken de verhoudingen in eerste instantie duidelijk. De patiënten zijn doodziek en officieel opgegeven door de artsen van het ziekenhuis, en het is zeker dat ze zonder medische hulp een moeizame en pijnlijke dood tegemoet gaan. Justus heeft als arts de middellen om ze voor zo"n dood te behoeden, en er is geen enkele reden om dat niet te doen. Hij beseft dat hij zich schuldig maakt aan hoogmoed, en dat hij en zijn collega's elkaar medeplichtig maken aan moord. Maar dat is nu eenmaal de logische consequentie van hun beroep. Justus ziet de kwalijke kanten van hun handelen, en hoewel hij blijk geeft van twijfel, kan hij daarmee leven. (Ibid.:25)

Moeilijker wordt het als hij met mevrouw sleutel over haar naderende dood praten moet. Hij weet niet hoe hij dat anders kan dan in eufemistische termen. 'Als het zo ver is ben ik bij u,' zegt hij, maar hij laat het aan haar over om in concrete termen te praten over haar doodsverlangen. (Ibid::144) Hij heeft daarvoor een logisch klinkend excuus. Artsen, zegt hij, hebben tot taak hun patiënten te genezen, niet te doden. Als ze vaststellen dat een zieke niet meer te genezen is, komt er een einde aan de behandeling. Maar als ze met een patiënt over de dood moeten praten, weten ze niet hoe dat moet. Net als God zwijgen ze als het om de dood gaat. Het liefst laten ze het daarom aan een uitbehandelde zieke zelf over om te concluderen dat hij of zij sterven zal:

Er is, $u$ weet het, in onze kringen een naam voor dit gesprek, Hang yourself. Het is de kunst de patiënt zelf de fatale conclusie te laten trekken. 
Ik begrijp de specialist wel. Ik begrijp hem beter dan wie dan ook. Hij wil heus God zijn, maar alleen als hij genezen kan. Voor genezen is hij opgeleid, verbluffende staaltjes kan hij daarvan vertellen, prachtige ogenblikken heeft hij meegemaakt, dankbaarheid geoogst. Misschien is hij er op zijn manier zelfs wel nederig van geworden. Beschouwt hij zich als een werktuig, als iemand die successen boekt omdat hij ontzag heeft voor de natuur. Maar zij is sterker, de natuur, en is zij onbehandelbaar geworden, de patiënte, dan is hij hulpeloos, en wil hij zwijgen. Net als de God waar hij allang niet meer in gelooft.

Kennis is vonnis. Dat iemand niet meer te genezen is, is niet alleen een feit, maar ook een besluit. Het moet worden uitgevoerd. De behandeling moet worden gestaakt. De patiënt moet worden ingeJicht. Liefst $z$ weeg de dokter dus, net als God.

Op zulk zwijgen zijn we niet berekend.

We bedenken een gesprekstechniek die ons minder machtig maakt - die de patiënt zijn eigen vonnis doet vellen.

(Ibid.:109, cursivering in origineel)

'Kennis is vonnis,' zegt Justus. Zo geeft hij aan dat hij ondanks zijn poging zich te distantiëren van zijn patiënte weet dat hij medeplichtig zal zijn aan haar onnatuurlijke dood. Door op een trucje terug te vallen, voorkomt hij dat hij door schuldgevoelens verteerd zal worden.

Zodra Justus te maken krijgt met de doodswens van dokter Daan, kan hij niet langer zijn schuld van zich afschuiven. Trucjes helpen in dit geval niet. Hij weet niet meer hoe hij reageren moet. Dokter Daan is immers miet lichamelijk ziek en daardoor is hij geen medisch geval. Bovendien stoot Justus hier op de grenzen van wat hij zelf acceptabel acht. Omdat Daan lichamelijk gezond is, bestaat er geen logische reden voor zijn doodswens. Was die er maar: 'Net als een toneelschrijver had ik een fatale plot nodig die dit einde noodzakelijk maakte,' zegt Justus. (Ibid.:161)

Justus doet zijn best zo professioneel mogelijk te handelen. Hij probeert Steffie gerust te stellen op de manier waarop hij mevrouw Sleutel gerustgesteld heeft. Als Steffie hem vraagt wat je moet doen als je weet dat iemand dood wil, probeert hij afstand te houden en objectief te blijven. Hier wordt pas goed duidelijk hoe zwaar hem dat valt. "Het lukte me warempel om te klinken als een arts,' zegt hij. (lbid.: 97) Maar terwijl hij haar vertelt, zoals het een professioneel handelende dokter betaamt, dat op die vraag geen eenduidig antwoord mogelijk is, voelt hij zijn hart bonzen. Zijn emoties laten zich minder makkelijk wegdringen dan hij hoopte.

En toch zou dat logischerwijze mogelijk zijn geweest. Dokter Daan 
laat slechts aan Steffie weten dat hij dood wil. Aan Justus vraagt hij alleen de volgende dag op een bepaald tijdstip langs te komen. Officieel weet Justus niets van dokter Daans plannen, en officieel is hij niet bij de zelfdoding van dokter Daan betrokken. Van medeplichtigheid aan een overtreding van een taboe is op het eerste gezicht helemaal geen sprake. Maar juist deze zogenaamde onwetendheid maakt Justus tot een tragisch personage. Hij weet niets, en toch weer wel, omdat anderen hem voortdurend waarschuwen dat er iets verschrikkelijks gaat gebeuren met dokter Daan. Die wetenschap maakt Justus, hoe hij het ook wendt of keert, medeplichtig in dubbele zin. Als hij weet te voorkomen dat Daan zichzelf doodt, redt hij een moordenaar het leven. Laat hij Daan zijn gang gaan, dan laat hij toe dat er een nieuwe moord gepleegd wordt. In beide gevallen maakt hij zich medeschuldig aan een misdaad. Justus probeert zichzelf er daarom voortdurend van te overtuigen dat hij niet echt weet wat er gebeuren gaat. Als dat niet lukt, onderneemt hij een paar halfhartige pogingen om dokter Daan van zijn voornemen af te brengen. Hij gaat bij hem langs en probeert met hem te praten, maar echt ingrijpen doet hij niet.

Dat Justus niets doet om dokter Daan tot andere gedachten te brengen, is al erg genoeg. Justus' redenen om dat niet te doen, maken zijn beslissing ronduit dramatisch. Hij laat zich weer door motieven leiden die, op zijn zachtst gezegd, niet edel zijn. 『ustus is jaloers op dokter Daan. Daarvoor heeft hij redenen genoeg - dokter Daan lijkt met alle vrouwen in Daans directe omgeving een verhouding te hebben gehad en heeft blijkbaar nog steeds een relatie met Steffie. Ook is Justus jaloers op dokter Daans reputatie; Justus is immers de jonge opvolger die in de ogen van dokter Daans vroegere patiënten niet zo kundig en vertrouwenswaardig kan zijn als de oude dokter. Bovendien voelt hij zich vernederd door dokter Daan. Als puber heeft hij hem ooit geconsulteerd in verband met een pukkeltje op zijn penis, en hij weet dat dokter Daan daarover met Steffie gesproken heeft. Steffie op haar beurt vertelt hem dat ze in precies dezelfde tijd als zeventienjarige min of meer op aanraden van dokter Daan met Justus gevreeën heeft, omdat ze door een groeistoornis klein is gebleven en wille ervaren dat ze desondanks aantrekkelijk was. (Ibid.:164-165)

Het probleem is echter niet zozeer dat Justus zich door jaloezie laat leiden, maar dat hij dat voor zichzelf ontkent. Om een uitweg te vinden uit al zijn verschillende gevoelens, neemt hij zijn toevlucht tot rationaliseringen. Hij bedenkt verschillende redenen waarom dokter Daan sterven moet. Als hij van Steffie hoort dat dokter Daan zijn vrouw geholpen heeft bij haar zelfdoding, roept hij uit dat het Daans verdiende straf is dat hij sterft - dokter Daan heeft immers een moord gepleegd. Bovendien, 
bedenkt hij, laat dokter Daan Steffie door zijn beslissing lijden, en wie zijn vriendin lijden laat, heeft geen recht te leven. (Ibid.:148) Hij bedenkt dat wie zichzelf doodt, te kennen geeft dat hij of zij een lafaard is. "Er was geen sprake wan medelijden, alleen van misselijkheid, en smalende gedachten," zegt hij, terugblikkend op de uren die aan de dood van dokter Daan vooraf zijn gegaan:

Dit is het dart dus. U hebt een strijd verloren. De nederlaag der nederlagen geleden. En toch heeft $u$ de eer aan zich zelf willen houden. Want dat is zelfmoord. Een manier om toch nog je hachje te redden. Ze waren smalend, bijna honend, mijn gedachten, alsof ik wilde zeggen: $u$ hebt uw recht verspeeld op mijn inleving. Ik wil niet eens meer weten wie u bent geweest, welke strijd u hebt geleverd. Valt $u$ in godsnaam alsnog dood.

(lbid.:149)

Iedereen die betrokken is bij een onnatuurlijke dood, maakt zich schuldig aan moord. Zolang Justus die betrokkenheid beschouwen kan als een logisch gevolg van zijn beroep, lijkt die wetenschap geen al te grote problemen op te leveren. Maar de dood van dokter Daan laat zien dat de betrokkenheid bij moord nooit eenduidig en logisch is. Daardoor beseft Justus dat hij ook in het geval van de patiënten Galesloot en Sleutel het noodlot getart heeft. Door de doodsverlangens van meneer Galesloot, mevrouw Sleutel en dokter Daan wordt hij geconfronteerd met al zijn tekortkomingen: met zijn hoogmoed, die hem laat denken dat hij zich meten kan met God; met zijn jaloezie en met zijn neiging alles wat hij verkeerd doet recht te praten met strikt rationele argumenten. De dood van een patiënt, kortom, maakt hem duidelijk dat hij mens onder de mensen is en dat hij zich daarom niet onttrekken kan aan medeplichtigheid. Wat geldt voor Justus, geldt uiteraard ook voor de artsen in het ziekenhuis. Ook zij verschullen zich achter de zogenaamde objectiviteit van hun oordelen, maar maken zich schuldig aan hoogmoed. Zij betrekken Justus en zijn collega Verdurmen bij het overschrijden van het taboe op moord.

Dokter Daan ten slotte maakt iedereen medeplichtig aan moord. Je zou kunnen zeggen dat hij zijn omgeving door zijn zelfgekozen dood zo weinig mogelijk belasten wil. Hij vraagt Justus expliciet pas te komen op een tijdstip waarop hij, dokter Daan, dood zal zijn. Hij wil met niemand over zijn dood praten, opdat niemand met zekerheid weet wat er gebeuren gaat. Alleen Steffie breekt door zijn isolement heen. Toch begrijpt iedereen, inclusief Justus, dat dokter Daan een einde aan zijn leven gaat maken. De vrouwen weten dat hij niet verder wil leven, en het feit dat dokter Daan op de sterfdag van zijn vrouw onbereikbaar is, zegt hun ge- 
noeg. Justus wordt keer op keer door hen gewaarschuwd. Maar ook al hadden de vrouwen hem níet op hun vermoeden gewezen, dan zou de mysterieuze afspraak van dokter Daan op zijn minst argwaan moeten wekken. Het is, zo lijkt Otten te willen zeggen, bijna onmogelijk je omgeving niet bij je eigen dood te betrekken, zelfs al probeer je je plannen te verzwijgen. Sterker nog, het zwijgen van dokter Daan spreekt boekdelen. Het maakt zijn omgeving daardoor bijna medeplichtiger aan zijn dood dan wanneer hij vrijelijk gesproken had over zijn voornemen. In dat laatste geval hadden zijn vrienden immers net als Steffie kunnen proberen hem van zijn voornemen af te brengen. Nu doen ze alsof ze niet weten wat er gebeuren gaat, terwijl ze dat wel vermoeden.

Degene die het meest schuldig én medeplichtig is aan dokter Daans dood, is Justus. Hij beschikt in principe over alle middelen om dokter Daan van diens plan af te brengen. Hij zou dokter Daan kunnen behandelen met antidepressiva en hij zou andere hulpverleners kunnen inschakelen. Het is alsof dokter Daan weet dat Justus niets zal doen om de zelfdoding te verhinderen. Daardoor lijkt hij niet alleen zichzelf te straffen, maar ook Justus. Zichzelf voor de hulp die hij zijn vrouw heeft gegeven en Justus voor diens hoogmoed.

\section{Slotsom}

Als we Ons mankeert niets als een tragedie lezen, moeten we vaststellen dat de vijfde zorgvuldigheidseis, volgens welke een arts die euthanasie gepleegd heeft van te voren tenminste één onafhankelijke collega geraadpleegd moet hebben, artsen niet vrijwaart van medeplichtigheid aan moord, maar hen in tegendeel medeplichtig maakt aan de overtreding van een verbod. Wie door een ander betrokken wordt bij euthanasie of hulp bij zelfdoding, is automatisch schuldig aan betrokkenheid bij moord. Die betrokkenheid kan op een directe of indirecte manier tot stand komen. Dokter Daan vertelt Steffie dat hij sterven wil. Justus laat hij niet expliciet weten wat hij van plan is. Toch kan Justus vermoeden dat dokter Daan van plan is zich om te brengen. Daardoor is hij medeplichtig aan moord. Dokter Daan is medeplichtig aan de dood van zijn vrouw, en hij makkt de mensen in zijn omgeving tot medeplichtigen. Justus op zijn beurt wordt door zijn patiënten en door de artsen in het ziekenhuis bij de overtreding van het verbod op moord betrokken, en betrekt daarbij ook zelf zijn collega. Justus erkent zijn medeplichtigheid pas als hij na de zelfdoding van dokter Daan alles verloren blijkt te hebben. Dan pas geeft hij toe dat zijn pogingen om een afstandelijke verhouding met zijn patiënten te onderhouden, mislukt zijn. We bestaan hoe dan ook voor zover we met anderen samenhangen. Als die anderen het verbod op moord overtreden, zijn wij vanzelf medeplichtig. 
In de wet toetsing levensbeëindiging op verzoek en hulp bij zelfdoding spelen officielle verklaringen een grote rol. Een arts wordt niet vervolgd als een patient uitdrukkelijk te kennen gegeven heeft dat die niet langer leven wil. Bovendien moet de betreffende arts samen met de patiënt en met collega's officieel tot de conclusie zijn gekomen dat de patiënt ondraaglijk lijdt en dat diens situatie uitzichtloos is. Nadat euthanasie is uitgevoerd, moet de arts dit officieel melden bij de gemeentelijke lijkschouwer.

Justus hecht grote waarde an officiële, schriftelijke verklaringen. De verklaringen van het ziekenhuis betreffende de lichamelijke toestand van de patiënten Galesloot en Sleutel gebruikt hij als een vrijbrief. Omdat daarin officieel gemeld wordt dat beide patiënten opgegeven zijn, heeft hij er geen enkele moeite mee euthanasie toe te passen. Een schriftelijke verklaring legitimeert zijn handelen, vooral als dat niet helemaal overeenkomstig de voorschriften is. Als Galesloot overleden is, vult Justus op de Verklaring van Overlijden in dat zijn patiënt een natuurlijke dood gestorven is. Hij houdt zich daarbij aan de regels:

Ik wist ook dat ik nog zijn Verklaring van Overlijden moest invullen. Als dat ik hem persoonlijk geschouwd had. Als dat ik erwan overtuigd was dat de dood was ingetreden ingevolge een natuurlijke oorzaak. Ik was ten slotte de behandelend arts.

(lbid.:23)

Justus drijft weliswaar de spot met de manier waarop hij omgaat met de Verklaring, maar de dood van Galesloot blijft voor hem beheersbaar, omdat die officieel en schriftelijk gesanctioneerd is. Het grote gevaar is dat Justus zich, zodra hij een officiële verklaring in handen heeft, vrij voelt om een patiënt een dodelijke dosis pijnstiller te geven, zonder dat die patiënt daar uitdrukkelijk om gevraagd heeft. Het papier geeft Justus het gevoel dat hij het recht heeft te beslissen over leven en dood. In het geval van meneer Galesloot doet hij dat zonder gewetensnood: de artsen hebben Galesloot opgegeven, Galesloot heeft ooit te kennen gegeven dat hij een zachte dood wil sterven, en hoewel Galesloot niet meer bij kennis is, bepaalt Justus met de officielle papieren in zijn hand dat de patiënt sterven moet. Die houding bepaalt ook Justus' gedrag ten opzichte van mevrouw Sleutel. Wat zij en haar gezin willen, interesseert hem niet. De schriftelijke verklaring van de artsen in het ziekenhuis is het enige wat telt: die geeft hem een machtiging om in hun levens in te grijpen. Justus lijkt dankzij die machtiging de toekomst te kunnen bepalen. 
Ironisch genoeg is het tegendeel waar. Justus' geloof in de almacht van de geschreven verklaring is een illusie. Justus' patiënten leven met eenzelfde soort illusie. Meneer Galesloot dacht waarschijnlijk dat hij zelf het tijdstip van zijn dood bepaald heeft, maar in werkelijkheid nemen Justus en zijn collega die beslissing. Mevrouw Sleutel denkt dat Justus haar bij het sterven helpen zal, omdat zij hem om euthanasie gevraagd heeft. Justus wil haar echter alleen maar helpen, omdat hij die handeling door de artsen van het ziekenhuis gesanctioneerd weet.

Zodra Justus denkt dat hij de toekomst in de hand heeft, neemt hij een beslissing die niet eens wettelijk door de beugel kan: hij, of zijn collega, geeft Galesloot een dodelijke injectie, zonder dat die daarom gevraagd heeft. Hun blind geloof in de macht van een schriftelijke verklaring maakt hen tot moordenaars.

Dokter Daans ingrijpen in de toekomst ten slotte heeft grote gevolgen voor zijn hele omgeving. Zijn dood lijkt als dubbele wraakactie vooral de twee mensen te straffen die ingegrepen hebben in de loop van een mensenleven: hijzelf en Justus. Dat daarmee ook de levens van Steffie en Justus' gezin ingrijpend veranderen, is dubbel tragisch.

Er komt nog een andere schriftelijke verklaring in Ons mankeert niets voor. Sterker, de roman ís een schriftelijke verklaring. De roman is het verslag dat Justus schrijft, nadat hij na de ontdekking van de dood van dokter Daan naar Friesland is gevlucht.

Justus schrijft zijn verslag niet alleen om het tuchtcollege te vertellen wat er precies gebeurd is in de nacht van achtentwintig op negenentwintig maart. Hij stelt zijn verhaal ook op schrift om zich bewust te worden van wat hij gedaan heeft en vooral wat hij verkeerd gedaan heeft.

Het verschil tussen Justus' schriftelijke verklaring en een schriftelijke wilsverklaring ligt voor de hand: Justus wil begrijpen wat er gebeurd is, terwijl iemand die een wilsverklaring opstelt, zijn of haar toekomstig lot beïnvloeden wil. Maar volgens Justus zijn we veranderd zodra we begrijpen wat we gedaan hebben: 'We schrijven, maar als we kunnen begrijpen wat er staat zijn we niet langer die we waren toen we schreven." (Ibid.:178)

Dit verschil is cruciaal. Als we een wilsverklaring opstellen, gaan we ervan uit dat wij de toekomst bepalen kunnen. Als we zo denken, hebben we een bijna statisch begrip van de tijd: dan gaan we ervan uit dat we in de toekomst dezelfde ideeën zullen hebben als in het heden, en dat we ons inleven kunnen in toekomstige situaties. We wanen ons heer en meester over de loop der dingen en menen we dat we praten kunnen over de dood. Maar ook dat is een illusie. Dokter Daans dood geeft het niets-zijn en de onbespreekbaarheid van de dood mooi weer. Dokter Daan vraagt Justus op een bepaald tijdstip bij hem te komen, maar wan- 
neer Justus die afspraak nakomt, valt er niets meer te doen en niets meer te bespreken. De afspraak is geen afspraak meer. Met andere woorden: wie zijn dood probeert vast te leggen, legt niets vast, maar geeft juist zijn of haar beslissingsmogelijkheden op.

Wie echter, zoals Justus dat ten slotte doet, het schrijven ziet als een handeling die het verleden begrijpen doet, beschouwt de tijd als een vloeiende beweging. Door te schrijven over zijn lotgevallen, verbindt Justus in één streek het verleden, het heden en de toekomst: de toekomst is voor hem dan niet langer een onbepaalde tijd die men beïnvloeden kan vanuit het heden, maar een tijd die besloten zit in het verleden en het heden. Zodra we door het schrijven het verleden begrijpen, zijn we niet meer wie we waren, en zullen we ook in de toekomst een ander zijn. Wanneer we het verleden aanschouwen, zien we dat het lot onze levens stuurt. 'Alles wat die nacht gebeurd is,' begrijpt Justus, 'is eerder die dag begonnen. Veel is toeval, maar wordt met terugwerkende kracht een plan.' (Ibid::103) Wat dat plan was, weet hij pas nadat hij alles opgeschreven heeft.

\section{Slotsom}

Schriftelijke wilsverklaringen, begrijpen we na deze lezing van Ons mankeert riets, zijn van generlei waarde, omdat daarin uitspraken gedaan worden over een toekomst die wij niet kennen. Schriftelijke verklaringen zeggen altijd alleen iets over een opvatting die iemand ooit had. Op het moment dat ze gebruikt worden, zijn ze in feite passé. Schriftelijke verklaringen hebben altijd betrekking op het verleden. Nooit op de toekomst, en daarom ook nooit op het heden.

\section{Samenvatting en conclusie}

A]s we Ons mankeert niets lezen volgens Ottens opvatting van de tragedie komen de verschillende problemen aan de orde die opgeworpen worden door de zorgvuldigheidseisen van de wet op euthanasie en hulp bij zelfdoding. In deze lezing worden de kwestie van het recht op zelfbeschikking en een al te rationele omgang met euthanasie verwoord. Justus worstelt immers voortdurend met de definities van uitzichtloos en ondraaglijk lijden. Hij wordt bovendien geconfronteerd met de problemen van overleg en consultatie en hij ontdekt de macht en de onmacht van het geschreven woord. Maar het belangrijkste probleem waarmee zowel Justus als dokter Daan te maken heeft, is dat waarvoor de zorgvuldigheidseisen in wezen opgesteld zijn: het probleem van de positie van artsen tegenover patiënten - artsen die met hun kennis, hun houding en de 
middelen die hun ter beschikking staan in feite geheel alleen over het lot van hun patiënten beslissen kunnen, of denken over dat lot beschikken te kunnen.

Justus gaat met dat probleem om zoals de moderne wetenschap dat volgens Otten van artsen verlangt: hij maakt een scherp verschil tussen gevoel en verstand. Die houding creëert verschillende problemen. Zolang Justus zijn handelingen rationaliseren kan, lijkt hij geen problemen te hebben metzijn patiënten en hun verzoek om euthanasie. Dat wil zeggen: als een zieke officieel is opgegeven, past Justus zonder gewetensbezwaren euthanasie toe, en is hij zelfs in staat dat te doen zonder uitdrukkelijk verzoek van de betreffende patiënt. Wanneer Justus zich beperkt tot abstracte redeneringen en oordelen, gedraagt hij zich als een god en lijkt hij degene te zijn die beslist wanneer een patiënt zal sterven. Officiële regels beperken zijn macht over zijn patiënten niet, maar rechtvaardigen die.

Zodra Justus zijn emoties niet langer onder controle heeft, en dus geen scheiding aanbrengen kan tussen verstand en gevoel, raakt hij in verwarring. Dan wordt duidelijk dat het recht op zelfbeschikking, dat lijden, consultatie en schriftelijke wilsverklaringen complexe fenomenen zijn die vatbaar zijn voor meer dan één uitleg. Bovendien beseft Justus achteraf dat al zijn handelingen gestuurd zijn. Pas nadat hij dokter Daan dood aangetroffen heeft, begrijpt hij dat hij twee dagen lang precies dat gedaan heeft wat dokter Daan van hem verlangde. Ook die gespletenheid, die eeuwige strijd tussen het ene willen en het andere doen, maakt van Justus een tragisch personage. Hij doet voortdurend dingen die niet mogen, maar die toch gebeuren. Hetzelfde geldt voor dokter Daan.

De tragiek van Justus en van dokter Daan maakt Ottens bezwaren tegen de euthanasiediscussie duidelijk. We denken dat we op een zuiver rationele manier over de kunstmatige dood kunnen praten en dat we op een zuiver rationele wijze beschikken kunnen over onze levens en die van onze patiënten, maar in werkelijkheid zijn al onze handelingen doordrongen van irrationele emoties. Bovendien vergeten we al te makkelijk dat we in elk opzicht verbonden zijn met anderen: artsen staan, hoe professioneel zij ook denken te handelen, altijd in een bepaalde verhouding tot een patiënt. Die verhouding bepaalt hun omgang met de patiënt. In het contact tussen een arts en een patiënt spelen altijd irrationele gevoelens of persoonlijke motieven een rol. Als Justus op huisbezoek gaat bij de doodzieke mevrouw Sleutel, is hij onhebbelijk tegen haar omdat ze erop staat met dokter Daan te spreken - hij kan zijn jaloezie slechts met moeite onderdrukken. Hij is jaloers op dokter Daans reputatie, op Steffies liefde voor dokter Daan en op diens vermogen zijn vrouwelijke patiënten te "raken". Hij voelt zich bovendien door dokter Daan 
vernederd vanwege een kwestie uit zijn puberjaren. Maar Justus zoekt voortdurend naar rationele argumenten orn de zelfdoding van dokter Daan te rechtvaardigen: dokter Daan heeft zijn vrouw geholpen bij haar zelfdoding en is dus een moordenaar; dokter Daan behandelt Steffie niet goed genoeg, en wie is Justus tenslotte om dokter Daan van zijn plannen af te helpen? Justus "redeneert zich suf", om Otten te parafraseren, omdat hij weet dat hij zich inlaat met iets waarmee een mens zich niet mag inlaten. Zijn rationele overwegingen zijn redeneringen achteraf: in werkelijkheid wordt hij geconfronteerd met een dilemma dat allesbehalve rationeel is. De dood van dokter Daan is bovendien, anders dan Justus geneigd is te denken, geen oplossing van een probleem. Met dokter Daans zelfdoding beginnen de problemen pas.

Ook dokter Daan gedraagt zich als een god, ook al gaat hij heel anders met zijn patiënten om dan Justus. Hij heeft bijvoorbeeld aandacht voor de tweede klacht en zijn aanraking is, anders dan die van Justus, intiem en bedoeld om een nauwe band met de patiënten te creëren. Maar in die bedoeling schuilt een gevaar. Dokter Daan maakt door de intieme relaties die hij met zijn vrouwelijke patiënten aangaat, die patiënten emotioneel van hem afhankelijk. Zijn verhouding tot zijn patiënten en tot Justus kun je daarom patriarchaal noemen. Als een poppenspeler bepaalt hij het doen en laten van Justus. Ook hij denkt over leven en dood te kunnen beschikken. Hij doodt zijn vrouw, en maakt ten slotte een einde aan zijn eigen leven. Met zijn dood lijkt hij niet alleen zichzelf, maar ook Justus voor diens hoogmoed te straffen.

Dat laatste geeft niet alleen het dilemma van de wet op euthanasie weer, maar ook het dilemma van de roman. Als we Ons mankeert niets als een tragedie lezen, moeten we vaststellen dat de dood een buitenmenselijke aangelegenheid is. Deze tragedie maakt duidelijk dat de mens zijn eigen meester niet is. De personages die menen dat zij hun eigen leven en dat van anderen bepalen kunnen, worden gestraft voor hun hoogmoed. Wanneer we Ons mankeert niets lezen vanuit die gedachte, moeten we tot de conclusie komen dat we mogen hopen dat we nooit geconfronteerd worden met de vraag "wat doe je als je weet dat iemand dood wil?". Zodra we met die vraag te maken krijgen, zijn we immers hoe dan ook tragische personages. Nooit zullen we een juiste beslissing nemen kunnen. Of we ons nu afzijdig houden of niet, we maken ons in alle gevallen schuldig aan de overtreding van een taboe: damned if we will, and damned if we won't. Een tussenoplossing lijkt volgens deze lezing niet mogelijk.

Veel artsen zullen dit antwoord niet bevredigend vinden. Je kunt je voorstellen dat artsen uit compassie met hun patiënten ingaan op hun verzoeken om euthanasie. ${ }^{32}$ Ook weigering van een euthanasieverzoek 
kun je als machtsmisbruik beschouwen. En hoewel sommige artsen kritiek hebben op de wet op euthanasie en op het toepassen van de zorgvuldigheidseisen, mogen we niet vergeten dat de wet en de eisen gebaseerd zijn op de voorstellen van ervaren artsen zelf. De huidige zorgvuldigheidseisen zijn bijna identiek aan de criteria die de Koninklijke Nederlandsche Maatschappij tot bevordering der Geneeskunst in 1985 opstelde in een voor een voor alle betrokkenen zo acceptabel mogelijke euthanasieprocedure. ${ }^{33}$ Dat zou erop kunnen wijzen dat regels niet per se op de werkelijkheid gelegd worden en de werkelijkheid manipuleren, maar ook uit de concrete ervaring voortkomen kumnen. Wellicht zien ervaren artsen in de spanningen en dilemma's waarmee de protagonisten van Ons mankeert niets geconfronteerd worden geen verwijzing naar het lot, maar beschouwen ze die als een afspiegeling van de complexiteit van de dagelijkse realiteit die slechts met behulp van regels in acceptabele banen geleid kan worden. In dat geval zouden we Justus en dokter Daan niet als tragische personages hoeven te beschouwen. Beiden nemen immers beslissingen die soms goed zijn en soms fout, precies zoals iedereen dat in de dagelijkse werkelijkheid doet. Justus is niet alleen hoogmoedig, maar heeft geregeld momenten van inzicht, waarop hij zijn eigen hoogmoed laakt. En dokter Daan mag zich dan als een patriarch gedragen, zijn patiënten houden echt van hem en voelen zich, zoals uit bijvoorbeeld Steffies verhaal blijkt, echt door hem begrepen. Zo lijken er ook aan alle andere aspecten van de roman twee kanten te zitten die de zorgvuldigheidseisen in een ander licht stellen. Als we bijvoorbeeld naar de eerste eis kijken, zien we dat Justus inderdaad ten onrechte zelf het initiatief neemt om meneer Galesloot een overdosis pijnstiller te geven. Zijn beslissing druist volkomen in tegen de doelstellingen van de wet die dergelijk eigenmachtig handelen juist voorkomen wil. Je kunt echter ook beargumenteren dat meneer Galesloot gestorven is op een manier die hij zelf gekozen had. Hij had Justus immers laten weten dat hij sterven wilde zodra hij opgegeven was. Dat Justus iets doet dat niet mag, maar begrijpelijk is, hoeft niet als tragisch opgevat te worden. In 2003 werd de huisarts van wijlen Cees de Wendel van Joode veroordeeld, omdat hij een einde aan het leven van een ondraaglijk lijdende en ongeneeslijk zieke patiënte gemakt had zonder te voldoen aan de zorgvuldigheidseisen. Ook hij deed iets dat begrijpelijk was, maar niet mocht. Maar is hij daarom een tragisch personage? Hij wist dat hij iets deed dat strafbaar was en hij wist dat hij daarvoor boeten zou. Niet omdat het lot hem treffen zou, maar omdat dat de consequentie zou zijn van zijn beslissing de zorgvuldigheidseisen te negeren. ${ }^{34}$ Justus' beslissing een einde te maken aan het leven van meneer Galesloot mag dan een tragisch gegeven zijn, zij correspondeert ook met de concrete ervaringen van bestaande artsen, die 
niets te maken lijken te hebben met de bepalingen van 'het lot' of met 'buitenmenselijke oplossingen'. Hetzelfde geldt voor alle andere beslissingen die in de roman gemaakt worden. Je zou ze tragisch kunnen noemen, maar evengoed realistisch. De zorgvuldigheidseisen op hun beurt kunnen gelezen worden als abstracte dogma's. Je kunt ze echter ook als richtlijnen beschouwen voor de omgang met de doodswens van een patiënt. De roman zelf lijkt dus ruimte te bieden voor een andere dan een 'tragische' lezing.

In deze andere lezing moet de dagelijksheid van het doen en laten van Justus en dokter Daan centraal staan. Daarmee doen we Otten en zijn werk geen geweld aan. Integendeel: Otten stelt in zijn essays voortdurend dat de literatuur, in tegenstelling tot de filosofie, de complexiteit van de dagelijkse ervaringen tot uitdrukking brengt. Zo bezien, kun je argumenteren, staat een tragische lezing van Ons mankeert niets haaks op Ottens opvattingen over de literatuur. Als we het boek als een tragedie lezen, verschuift immers het zwaartepunt van de dagelijkse ervaringen naar het buitenmenselijke, heeft de roman een morele boodschap en draagt deze een idee uit: wie zich inlaat met de dood, die buitenmenselijke aangelegenheid, overtreedt een taboe en zal het noodlot niet kunnen ontlopen. Ons mankeert niets als tragedie gelezen geeft niet zozeer de complexiteit van de concrete werkelijkheid weer, maar veel meer de kracht van een algemene, abstracte buitenmenselijke wet. 


\section{Ons mankeert niets als historie}

Otten schreef Ons mankeert niets omdat hij op zoek was naar andere kennis dan krantenkennis. Hij zocht naar kennis die de complexiteit van de dagelijkse ervaring weergeeft. Nu gaat het in deze roman om kennis van een bepaalde soort. Het ikpersonage wordt immers geconfronteerd met de vraag: wat doe je als je weet dat iemand dood wil?

Ottens antwoord op die vraag lijkt in eerste instantie eenduidig. Mensen die zich inlaten met de onnatuurlijke dood van een ander, maken zich schuldig aan de overtreding van het taboe op moord. Zelfs wanneer zij niet actief meehelpen bij de dood van een ander, maken zij zich alleen al door de kennis van een doodswens medeplichtig aan de overtreding van een taboe. Als je de roman leest vanuit dat gezichtspunt, kun je zeggen dat dit het lot van Justus is. Justus probeert zich er voortdurend van te overtuigen dat hij niets te maken heeft met de zelfdoding van dokter Daan. Rationeel gezien klopt dat, want officieel weet hij van niets. Toch wordt hij gestraft. Hij verliest zijn vriendin en zijn vrouw, en zal zich moeten verantwoorden tegenover het Medisch Tuchtcollege. Pas nadat hij uit Heimwou gevlucht is, begrijpt hij hoezeer zijn leven met dat van anderen verweven is. Dan ook ziet hij in dat hij zijn lot niet ontlopen kan.

Dokter Daan op zijn beurt heeft het noodlot getart door zijn vrouw te helpen bij haar zelfdoding. Hij mag dan minder gebruik maken van abstracte wetten en zuiver rationele overwegingen dan Justus, minder hoogmoedig dan zijn jonge opvolger is hij niet. Beiden overtreden zij het taboe op moord en richten zo zichzelf en hun naasten te gronde.

Als je Ons mankeert niets volgens Ottens opvatting van een tragedie leest, kun je de roman als een waarschuwing tegen de legalisering van euthanasie en hulp bij zelfdoding beschouwen: hoe je het ook wendt of keert, betrokkenheid bij de zelfgekozen dood van een ander is altijd verkeerd. Zo bezien biedt de roman algemene kennis en niet, zoals Otten stelt, kennis omtrent de dagelijkse werkelijkheid. Aan de dagelijkse erwa- 
ringen van artsen en patiënten, aan hun angsten, pijnen, gevoelens van medelijden en hulpeloosheid gaat ook deze lezing voorbij.

Maar we hoeven Ons mankeert niets niet alleen volgens Ottens opvatting van een tragedie te lezen. Als je afziet van mythische connotaties en dimensies, kun je het verhaal ook op een 'historische' manier tot je nemen, dat wil zeggen, zonder het verhaal te interpreteren als een verwijzing naar 'het buitenmenselijke'. De personages zijn dan niet langer speelballen van het lot, maar simpelweg twee willekeurige Nederlandse artsen en hun naasten met door en door menselijke eigenschappen als jaloezie en empathie, angst en verlangen, wier levens verstrikt raken door het doodsverlangen van één van hen. De roman geeft in dat geval minder algemene kennis van de manier waarop artsen moeten reageren als ze weten dat iemand sterven wil, maar meer inzicht in de motieven van de twee individuele artsen. Hun zorgen en problemen beschouwen we dan niet meer als tragisch, maar als alledaags.

Voor deze lezing zijn verschillende argumenten aan te voeren. Ten eerste nodigt Otten zelf ons uit zijn boek op een andere manier te lezen. Een roman, zegt hij, levert andere kennis dan een krantenartikel. De kennis die een roman ons biedt, heeft te maken met de dagelijkse, concrete ervaring. (Otten 1995a) Die ervaring is nooit eenduidig. Anders dan de filosofie wil de literatuur de concrete werkelijkheid niet analyseren en niet beheersen. De kennis die zij biedt is evenmin eenduidig. (Otten 1995b)

Het tweede argument komt uit het eerste voort. Ook Justus' gedrag is niet eenduidig. Zijn probleem is dat hij niet de altijd rationeel handelende arts is die hij zo graag wil zijn. Integendeel. Hij heeft te veel zelfkennis om zich voortdurend en zonder enige zelftwijfel als een god te gedragen. In het geval van de dood van meneer Galesloot bijvoorbeeld ironiseert hij zijn eigen houding. Het enige wat je hem verwijten kunt, is dat hij zijn zelfkritiek niet consequent doorvoert, en bijvoorbeeld niet toegeeft of niet merkt dat hij zich onder het mom van zijn hang naar professionaliteit door jaloezie laat leiden. Justus is domweg niet eerlijk genoeg tegenover zichzelf en alle mensen met wie hij te maken heeft. Maar stel. dat Justus niet geprobeerd had zijn emoties te verdoezelen, en zichzelf niet boven zijn patiënten gesteld had. Dat hij, zoals hij uiteindelijk in zijn verslag doet, onmiddellijk erkend had dat emoties een rol spelen bij de behandeling van bepaalde patiënten. Dan had hij met dokter Daan kunnen praten en Steffie kunnen helpen om dokter Daan van diens voornemen af te brengen. Als dat niet gelukt was, zou hij in elk geval een zuiver geweten hebben. Ook dat zou mogelijk geweest zijn. Er is in de roman, zo kun je stellen, niet per se een dringende noodzaak aan te wijzen waarom het noodlot hoe dan ook moet toeslaan, simpel en alleen omdat ie- 
mand te kennen heeft gegeven dat hij dood wil. Een ander werloop van het verhaal is denkbaar, omdat alles wat we over Justus lezen een andere afloop denkbaar maakt.

Ten derde is daar dokter Daan. Over hem kun je zeggen dat hij minder waarde hecht aan regels dan Justus, en dat hij zich ook minder leiden laat door jaloezie. Dokter Daan heeft een heel andere verhouding tot ziin patiënten dan Justus. Uit de reactie van mevrouw Sleutel blijkt dat dokter Daan heel anders zou handelen dan Justus wanneer hij weten zou dat iemand dood wil. Sterker nog, we weten dat hij anders reageert dan Justus. Hij heeft de doodswens van zijn vrouw ingewilligd, hoewel hij niet beschikte over een officieel attest van de draaglijkheid en uitzichtloosheid van haar lijden. Maar dokter Daan handelt hoe dan ook anders dan Justus. Hij lijkt geen strikte scheiding aan te brengen tussen gevoel en verstand. Hij laat in zijn verhouding tot zijn patiënten zijn emoties spreken. Maar dat betekent niet dat hij irrationeel handelt. Hij heeft aandacht voor de emoties van zijn patiënten. Dokter Daan geeft de tweede klacht voorrang boven de eerste, zonder dat hij daarbij de eerste uit het oog verliest. Hij heeft meer vertrouwen in zijn eigen oordeel en dat van zijn patiënten. dan in officiële aanwijzingen en oordelen. Zijn patiënten dragen hem daarom op handen. Als de zieke mevrouw Sleutel over euthanasie wil praten, wil ze dat alleen met dokter Daan doen. Justus, de afstandelijke professional, vertrouwt ze niet. Dokter Daan laat compassie en empathie zwaarder wegen dan de regels. Als hij twee jaar na de dood van zijn vrouw zichzelf doodt, heeft dat niets te maken met het noodlot. Daan wilde dood, zegt Steffie, gewoon, omdat hij niet verder leven wilde na het verlies van zijn zoon en vrouw. Wat je Daan zou kunnen verwijten, is dat hij zich te zeer heeft laten meeslepen door zijn emoties. Maar dat maakt hem niet minder menselijk dan Justus. Zijn dood had menselijkerwijs verkomen kunnen worden, en menselijkerwijs kun je ook begrijpen waarom hij sterven wil. Ook in dit geval hoeft er van het noodlot geen sprake te zijn.

Het vierde argument heeft te maken met Ottens intenties. In het artikel in Trouw, waarin hij zijn beweegredenen om zijn roman te schrijven. toelicht, zegt hij dat hij erachter wilde komen of er een dood bestaat die niemand belast. Voorstanders van legalisering van euthanasie en hulp bij zelfdoding beroepen zich dikwijls op het argument dat zelfdoding zonder professionele hulp de omgeving van degene die sterven wil te zeer onder druk zet. De patiënte van Chabot bijvoorbeeld gaf te kennen dat ze anderen niet tot last wilde zijn door voor een trein te springen. "Met Justus, dokter Daan, Hilde en Steffie,' schrijft Otten, 'heb ik op een dramatiserende wijze een menselijke, en in sommige ogen zelfs utopische mogelijkheid onderzocht: die van een zelfmoord die niemand belast, ge- 
pleegd door iemand die de Milde Dood zonder poespas in handen gespeeld heeft gekregen omdat hij zelf zijn eigen arts was.' (Otten 1995a) Otten komt tot de conclusie dat een dood die niemand belast, niet bestaat. 'Ik kon', zegt hiij aan het eind van het artikel, 'domweg het boek niet schrijven waarin iemand een einde aan zijn bestaan maakte zonder mijn personages, en dus mij, tot last te zijn.' (Ibid.) Maar Otten maakt niet duidelijk wat hij met 'last' bedoelt. 'Last' hoeft niet per se tragisch te zijn, ook niet voor de omgeving van dokter Daan. Dat wil zeggen: aan last hoeven de personages in de roman niet ten onder te gaan, net zoals dat geldt voor personen in het dagelijkse leven. Je kunt net zo goed stellen dat de dood altijd last veroorzaakt voor de nabestaanden, of het nu gaat om euthanasie of om een natuurlijke dood. Het komt zelden voor dat niemand getroffen wordt door de dood van een ander, al was het alleen maar omdat er ook rondom het sterven gezorgd moet worden, inclusief het verzorgen van het dode lichaam. Dat iemand die een milde dood sterven wil hoe dan ook last veroorzaakt, is daarom op zich geen argument tegen euthanasie.

Deze overwegingen kunnen een nieuw licht werpen op de interpretatie van Ons mankeert niets. Je kunt je afvragen of Justus" manier van handelen laat zien hoe hij niet moest handelen toen hij geconfronteerd werd met de doodswens van een ander, of waarom dokter Daan het zoveel makkelijker zou vinden met die vraag om te gaan. Om een mogelijk antwoord op deze vragen te vinden, wordt Ons mankeert niets in dit hoofdstuk een tweede keer gelezen. In deze tweede, historische lezing verschuift de aandacht van het algemene en het 'buitenmenselijke' naar het situatieve en het particuliere. Hierin staan de karakters van de personages en de alledaagsheid van de problemen waarmee Justus en dokter Daan geconfronteerd worden centraal. De vraag die in de eerste lezing als leidraad diende, blijft eveneens bij deze lezing van belang: hoe verhouden wet en werkelijkheid zich tot elkaar? In deze tweede lezing hebben we eveneens te maken met een al dan niet schijnbare discrepantie tussen wet en werkelijkheid. Volgens de eerste lezing is de wet een afspiegeling van een dolgedraaid rationalisme dat voorbiggat aan de macht van het lot. Maar ook als we onze aandacht op het concrete en het alledaagse richten, is het de vraag welke plaats een algemene wet daarin spelen kan. Daarom neemt in deze tweede lezing de omgang met de zorgvuldigheidseisen weer een belangrijke plaats in. Ook in dit hoofdstuk zijn de verschillende paragrafen ingedeeld aan de hand van de zorgvuldigheidseisen. 
Zelfbeschikking, zo lezen we in Ottens essays, is een illusie. De mens is een speelbal van het lot en zal, als hij de loop van zijn leven in eigen hand probeert te nemen, door het noodlot getroffen worden. De dood is een buitenmenselijke oplossing, en het staat ons niet vrij te beslissen over onze dood. Voor zieken is de zelfverkozen dood geen werkelijke oplossing, en artsen die besluiten het leven van een patiënt te beëindigen, zijn tragische personages. Zij kunnen het noodlot niet ontlopen.

Als we Ons mankeert niets volgens Ottens opvatting van de tragedie lezen, heeft het begrip 'zelfbeschikking' betrekking op zowel de arts als de patiënt. Justus lijkt het recht op zelfbeschikking te interpreteren als zíjn recht op beschikking over het leven van zijn patiënten. Hij en zijn collega Verdurmen bepalen wanneer meneer Galesloot sterven zal. Ook in zijn gesprek met mevrouw Sleutel laat Justus duidelijk merken dat hij de touwtjes in handen houden wil. Hij maakt weliswaar relativerende opmerkingen over de macht die hij uitoefent, maar daarmee bevestigt hij zijn positie alleen maar. Zijn uitspraken over de goddelijke macht die hij zich toe-eigent, maken duidelijk dat híj beslist wat er gebeurt. Daarmee trekt hij een macht naar zich toe die volgens Otten te groot voor mensen is. Hij bevindt zich daarom in een paradoxale situatie. Het lijkt alsof hij in vrijheid beschikken kan over het leven van een ander, maar in werkelijkheid stuurt het lot hem. " $[\mathrm{H}]$ oe dichter iemand staat bij het kunnen nemen van andermans leven,' schrijft Otten in een van zijn essays, 'des te minder handelt hij of zij uit dat wat wij dolgraag "vrije wil" zouden noemen. Dat is de tragische, tweeënhalfduizend jaar oude waarschuwing: hoe meer macht, des te minder greep op onze wil.' (Otten 1995d:64)

Afgaande op Ottens essays moet je concluderen dat ook Justus' vlucht aan het einde van het verhaal bepaald wordt door het lot. Maar je kunt ook stellen dat Justus' crisis veroorzaakt wordt door zijn pogingen zijn verstand en zijn emoties van ellkaar te scheiden. Zolang hij niet emotioneel betrokken is bij de levens van zijn patiënten, kost het hem geen enkele moeite euthanasie toe te passen. Maar wanneer hij zijn gevoelens niet onderdrukken kan, ontstaan er complicaties. Wanneer zijn emoties de overhand nemen, weet hij nauwelijks wat hij doen moet en neemt hij verkeerde beslissingen. Zijn weigering om het zieke kind met oorpijn te bezoeken, komt voort uit zijn verwarring over de afspraak met dokter Daan en de ontwikkelingen van zijn verhouding met Steffie. Wanneer Justus hoort dat dokter Daan de hand aan zichzelf wil slaan, raakt hij volledig in de war, niet alleen omdat hij zijn voorganger als een professionele concurrent beschouwt, maar vooral ook als een rivaal in de liefde. 
Toch leert het verhaal van Justus niet noodzakelijkerwijze dat het lot onze levens bepaalt. Het leert dat Justus' pogingen verstand en gevoel van elkaar te scheiden zwaarwegende gevolgen hebben voor de manier waarop hij omgaat met de levens van zijn patiënten. Wanneer hij zijn gevoelens onderdrukt, laat hij een patiënt zonder enige begeleiding en zonder overleg sterven. Als hij zuiver rationeel denkt te handelen, gedraagt hij zich precies zoals hij zelf zegt: als een god. Zodra hij echter zijn emoties de boventoon latat voeren, weet hij niet meer hoe hij handelen moet. En zodra hij niet meer zelf beschikken kan, laat hij zijn patiënten in de steek.

Dergelijk gedrag is menselijk en begrijpelijk. Het is niet aangenaam en je kunt het verwerpelijk noemen. Volgens de wet maakt Justus zich zelfs schuldig aan een strafbaar feit. Maar met de overtreding van een taboe hoeven zijn beslissingen niets te maken hebben. Justus heeft als jonge huisarts een praktijk overgenomen van een oude, geliefde dorpsarts. Hij is getrouwd en heeft twee kleine kinderen, maar wordt verlliefd op een oude jeugdvriendin - dat zijn allemaal zaken die hem onzeker maken. Die onzekerheid probeert hij te compenseren met rationaliseringen. Maar belangrijker is dat hij zich ervan bewust is dat hij dat doet: zijn verhaal kan als een zelfaanklacht gelezen worden. De kritiek die we op Justus hebben kunnen, reikt hij ons zelf aan.

Dat geldt ook voor de manier waarop Justus omgaat met de plannen van dokter Daan. Als Justus vermoedt dat dokter Daan zich van het leven beroven wil, raakt hij in paniek. Dat is echter niet omdat hij meent dat dokter Daan niet over zijn eigen leven beslissen kan. Integendeel: hij doet alsof hij niet weet dat dokter Daan zelfmoordplannen heeft, omdat hij op dat moment niet weet hoe hij daarop reageren moet. De complexiteit van zijn verhouding tot Daan verhindert hem op een afgewogen manier te handelen. Hij is jaloers op dokter Daan, maar hij heeft ook bewondering voor hem. Daarom is het makkelijker te besluiten dat Daan recht heeft op zelfbeschikking en het daarbij te laten dan met dokter Daan over zijn plannen te praten. Wat dat betreft kun je Otten gelijk geven: zelfbeschikking is een illusie. Niet noodzakelijkerwijze, zoals Otten stelt, omdat het lot over ons beslist, maar omdat we altijd te maken hebben met de wensen, verlangens en plannen van anderen. Zo bezien makt Ons mankeert niets duidelijk dat de eerste zorgvuldigheidseis uit de wet op euthanasie met de werkelijkheid niets te maken heeft.

Maar wat als er geen sprake is van een gecompliceerde verhouding tussen arts en patiënt? Wat, met andere woorden, als een arts zonder verborgen agenda en zonder persoonlijke problemen omgaat met het doodsverlangen van een ander? Dokter Daan heeft, voor zover we weten, met slechts één geval van onnatuurlijke dood te maken gehad: hij 
heeft zijn vrouw geholpen zich te doden. Als we op de reactie van mevrouw Sleutel mogen afgaan, stond dokter Daan ook open voor de doodswensen van zijn patiënten.

Dokter Daan lijkt makkelijker met emoties om te kunnen gaan dan Justus. Anders dan Justus laat hij zijn beslissingen niet afhangen van het attest van een hogere instantie. Hij en zijn patiënten bepalen zelf wanneer hun lijden uitzichtloos en ondraaglijk geworden is. Zij passen hun oordeel niet aan dat van de officiële instanties aan. Evelien Daan mankeerde lichamelijk niets. Ze leed aan depressies en wilde niet verder leven. Mevrouw Sleutel is weliswaar door het ziekenhuis opgegeven, maar zij weet dat dokter Daan, die ook haar heeft 'aangeraakt', haar helpen zal op een tijdstip en op een manier die haar het beste lijken, terwijl ze de afstandelijke en schijnbaar bureaucratische Justus ervan verdenkt dat hij haar in de kou zal laten staan.

Wanneer dokter Daan met euthanasie te maken krijgt, is er blijkbaar altijd sprake van een vrijwillige beslissing. Zijn patiënten beslissen immers zelf wanneer ze sterven. Ook bij hemzelf is dat het geval. Hij bepaalt wanneer en hoe hij doodgaat. Wanneer hij zijn patiënten helpt te sterven, zo kun je concluderen, doet hij dat precies zoals de wet verlangt, omdat ze hem vrijwillig om euthanasie verzocht hebben.

Maar volgt daaruit ook dat dokter Daan en zijn patiënten weloverwogen gehandeld hebben, zoals de zorgvuldigheidseisen van artsen en patiënten verlangen?

Op het eerste gezicht wel. Mevrouw Sleutel weet dat ze niet genezen zall, en Evelien Daan wilde na de dood van haar zoon niet meer leven. Er zijn echter twee problemen. Het eerste is dat ook dokter Daan macht uitoefent op zijn patiënten, niet strikt rationeel, door zich op zijn kennis en positie te beroepen, maar emotioneel. Justus probeert angstvallig afstand te houden van zijn patiënten. Wanneer Steffie voor het eerst op zijn spreekuur komt, vermoedt hij al gauw dat zij geen klachten heeft. Elke aanraking verandert daardoor achteraf in een intimiteit. Dat besef verwart hem en doet hem naar de gewoonlijke gang van zaken verlangen. ' $U$ droomt," zegt hij tegen degene voor wie zijn verslag bestemd is, "van het ideale consult met drie stiltes en een steekhoudend laatste woord. $U$ hebt uzelf per consult acht minuten toegewezen.' (Otten 1994d:47) Als hij zich toch door Steffie verleiden laat, is dat het begin van het einde van zijn loopbaan. Bij dokter Daan zijn dergelijke contacten eerder regel dan uitzondering. Maar de emotionele band tussen hem en zijn patiënten leidt voor zover we te horen krijgen niet tot problemen. Een van zijn oud-patiëntes verzekert Justus erwan dat dokter Daan niemand dwong tot intimiteiten. 'Dat je niet denkt dat ik me gebruikt voel of iets dergelijks, voegt ze eraan toe. (Ibid.) Justus heeft dat zelf ervaren. Als jonge 
man heeft hij zich door dokter Daan laten onderzoeken. De aanraking van dokter Daan, zegt hij, had iets moederlijks - het was een "betasting zonder bijbedoeling," en als dokter Daan je aanraakte 'was het alsof je je nooit meer ergens voor zou hoeven schamen, en al helemaal niet voor je schaamte". (Ibid.:117) Dokter Daan weet blijkbaar waar de grenzen van het acceptabele liggen. Niemand voelt zich door zijn aanraking tot object gedegradeerd. Integendeel, de aanraking van dokter Daan verbindt arts en patiënt in een relatie waarin de patiënten zich als individuen bevestigd voelen. Wel kun je hier tegenin brengen dat de emotionele band tussen dokter Daan en zijn patiënten te groot geworden is. Zijn patiënten maken zich op een gegeven moment meer zorgen om hem dan hij om hen. Daardoor lijkt het alsof dokter Daan te ver gegaan is. Zijn houding tegenover zijn patiënten lijkt te weinig professioneel geweest te zijn.

Het tweede probleem is dat dokter Daan zelf geen raad weet met het gegeven dat hij zijn vrouw heeft helpen sterven. Of beter: omdat zij dood is, wil en kan ook hij niet verder leven. Ook hij mankeert lichameliik gezien niets. Je kunt je daarom afvragen in hoeverre je in het geval van zijn zelfdoding spreken kunt van weloverwogenheid. le kunt je daardoor zelfs afvragen in hoeverre de beslissingen van Evelien Daan, mevrouw Sleutel en dokter Daan zelf vrijwillig genomen werden. In alle gevallen lijkt er sprake te zijn van een bepaalde mate van emotionele dwang. Mevrouw sleutel is na haar 'aanraking' door dokter Daan duidelijk emotioneel van hem afhankelijk geworden, Evelien Daan heeft haar beslissing genomen toen ze depressief was, en dokter Daan zelf heeft haar om emotionele redenen geholpen. Justus acht om verschillende redenen het verstand belangrijker dan het gevoel. Bij zijn collega lijkt dat precies andersom te zijn. Hij heeft zich door zijn emoties laten meeslepen. Bij zowel Justus als dokter Daan lijkt er dus sprake te zijn van een onevenwichtige verhouding tussen verstand en gevoel, en bij beiden leidt dat minstens twee keer tot onvrijwillige, niet doordachte sterfgevallen. Beiden komen door dit gebrek aan evenwicht ten val. Dokter Daan slaat de hand aan zichzelf en Justus slaat op de vlucht.

Toch vertrouwen dokter Daans patiënten hem en voelen zij zich vrij niet alleen hun lichamelijke klachten, maar ook hun angsten en hun verlangens voor te leggen. Lichamelijke klachten en emoties zijn volgens dokter Daan altijd met elkaar verweven. Dat spreekt vóór de wijze waarop hij met zijn patiënten omgaat en zorgt dat zijn manier van behandelen niet uitsluitend op emoties gericht is. Pas wanneer dokter Daan zijn eigen vrouw behandell, lijkt het mis te gaan. Dan ontbreken blijkbaar de afstand en de rationele overwegingen die in zijn relaties met zijn patiënten steeds aanwezig blijven en die de verhouding tussen hem en zijn patiënten evenwichtig houden. Als zijn vrouw te kennen geeft dat zij ster- 
ven wil, schikt hij zich naar haar wens en hij laat zich door haar emoties leiden. Vrijwillig en weloverwogen lijkt alleen de doodswens van Evelien Daan, niet dokter Daans besluit on haar bij haar zelfdoding te helpen.

Eenzelfde onevenwichtigheid ontstaat wanneer dokter Daan besluit een einde aan zijn eigen leven te maken. Ook zijn besluit lijkt vrijwillig en weloverwogen genomen te zijn. Maar Justus wordt tegen zijn wil bij de dood van zijn collega betrokken en raakt daardoor in moeilijkheden.

Wat een historische lezing van Ons mankeert niets leert, is dat we de zin 'We bestaan voor zover we met anderen samenhangen', die zoveel indruk op Justus maakt, niet als een verwijzing naar het noodlot hoeven te beschouwen. Dat we altijd betrokken zijn bij elkaars lotgevallen kunnen we ook als een simpel gegeven zien, zonder enige negatieve connotatie. Dokter Daan wi na de dood van zijn vrouw niet verder leven. Hij komt tot die conclusie door te praten met de mensen om wie hij geeft. In eerste instantie zwicht hij voor Steffies argumenten tegen zijn zelfdoding. Maar in de tweede instantie weet hij haar te overtuigen dat hij niet verder leven kan. De begrippen 'vrijwilligheid' en 'weloverwogenheid' hoeven niet haaks te staan op de verbondenheid van mensen. Je kunt in verbondenheid met een ander vrijwillig en op weloverwogen wijze tot het besluit komen een einde aan je leven te maken of te laten maken. Maar wat dokter Daans beslissing ook leert, is dat vrijheid en weloverwogenheid relatieve begrippen zijn. Dokter Daan, zo zou je kunnen zeggen, laat zich meeslepen door zijn gevoelens als hij zijn vrouw helpt te sterven. Hij wil daarna ook zelf sterven. Je kunt je daarom afvragen hoe vrijwillig zijn eigen dood is. Hoe weloverwogen zijn beslissing is, weten we ook niet. Tijdens de laatste uren van zijn leven verschuilt Dokter Daan zich voor Justus, en met Hilde wil hij ook niet spreken. Hij staat alleen Steffie te woord. Maar Steffie heeft het gevoel dat ze geen gesprek meer met hem voeren $\mathrm{kan}$. Steffie is hierover diep bedroefd en voelt zich in de steek gelaten. Justus vult de Verklaring van Overlijden verkeerd in en slaat op de vlucht.

\section{Slotsom}

Als we Ons mankeert niets lezen als een tragedie volgens Ottens opvatting, kan er wat euthanasie betreft van vrijheid en weloverwogenheid nauwelijks sprake zijn. Als we de roman lezen als een 'historisch' verhaal waarin het lot of het noodlot geen enkele rol speelt, wil dat nog niet zeggen dat Justus op een adequate of legale wijze met de doodswensen van zijn patiënten omgaat. Die lezing maakt zijn manier van handelen wel begrijpelijker. Justus is jong, onervaren, onzeker en bovendien jaloers op dokter Daan. Hij zal niet de eerste arts zijn die uit onervarenheid en on- 
zekerheid de verkeerde beslissingen neemt. Maar uiteindelijk ziet hij in dat hij fouten heeft gemaakt, en hij begrijpt ook waarom hij dat heeft gedaan.

Dokter Daan lijkt niet gekweld te worden door onzekerheid en jaloezie. Hij geeft $z$ ijn patiënten volop gelegenheid om over hun angsten en zorgen te vertellen. Hoewel we niet weten of hij ooit door een patiënt om euthanasie gevraagd is, mogen we aannemen dat hij die vraag niet uit de weg zou gaan. Mevrouw Sleutel weet immers zeker dat dokter Daan haar zou helpen een zachte dood te sterven. We mogen ook aannemen dat dokter Daan zijn patiënten de kans zou geven in alle wrijheid en op een weloverwogen manier tot een beslissing over euthanasie te komen. Dokter Daan respecteerde de wensen van zijn patiënten, zoals hij de wens van zijn vrouw respecteerde. Zijn vrouw nam, zo zou je kunnen zeggen, haar beslissing vrijwillig en weloverwogen. Toch heeft dit verhaal geen happy end. Je kunt ook stellen dat dokter Daan zich in het geval van de dood van zijn vrouw door zijn emoties heeft laten meeslepen. Zijn dood leidt ten slotte tot paniek en verdriet bij de mensen uit zijn omgeving.

\section{De tweede klacht}

Artsen die euthanasie plegen worden niet vervolgd, zegt de wet, wanneer het lijden van hun betreffende patiënten uitzichtloos en ondraaglijk was. Otten schrijft in zijn essays dat het onmogelijk is vast te stellen wanneer lijden uitzichtloos en ondraaglijk geworden is: lijden kan immers niet objectief gemeten worden. Bovendien, zegt hij, hoort het lijden bij het leven. Een leven zonder $\$ ijden is ondenkbaar. Lijden maakt het leven, anders dan veel mensen vrezen, niet zinloos. Integendeel, lijden geeft het leven een bepaalde zin.

Justus lijkt geen problemen te hebben met de bepalingen van de wet. Hij noemt het lijden van een patiënt pas uitzichtloos en ondraaglijk wanneer hij daartoe officieel toestemming heeft gekregen. Zodra een patiënt officieel uitbehandeld is, heeft Justus er geen enkele moeite mee euthanasie toe te passen. Sterker nog, hij vindt het heel normaal die patiënten een te hoge dosis pijnstiller te geven, ook als ze er niet extra om gevraagd hebben.

Problemen krijgt Justus pas als iemand sterven wil die geen lichamelijke klachten heeft en volgens de officiële normen niet uitzichtloos en ondraaglijk lijdt. Justus verschilt daarom op het eerste gezicht niet van de artsen die Otten in zijn essays bekritiseert: hij handelt alleen volgens officiële richtlijnen. Hij houdt nauwelijks rekening met de wensen van de 
patiënt. Patiënten beschouwt hij als gevallen, als objecten bijna. Onder lijden verstaat Justus alleen lichamelijk lijden. Hij behandelt altijd alleen de eerste klacht. Dat heeft tot gevolg dat mevrouw Sleutel niet met hem over euthanasie wil praten. Liever praat ze daarover met dokter Daan, omdat ze weet dat hij haar angst voor een pijnlijke dood serieus zal nemen.

Maar dat wil niet zeggen dat Justus niet weet hoe belangrijk het is om goed naar de tweede klacht te luisteren. Hij heeft zelf ooit ervaren hoe dokter Daan zich op de tweede klacht richtte, en hoe weldadig dat is. Dokter Daan accepteerde dat lichamelijk gezonde mensen kunnen lijden en, vooral, dat hij daaraan als arts iets kon doen. Hij gaf zijn patiënten zoveel mogelijk aandacht, en hij leefde zich in hun problemen in. Toen Justus hem als achttienjarige consulteerde, was hij even bang dat dokter Daan hem zou uitlachen - Justus' eerste klacht was immers niet ernstig. 'Maar dokter Daan lachte me niet uit,', zegt Justus, 'hij gaf me het gevoel dat hij om zichzelf lachte.' (Otten 1994d:116) Dokter Daan richtte zich bij de behandeling niet naar officiële verklaringen, maar naar de beleving van zijn patiënten. Zo stelt hij vast of hun lijden uitzichtloos en ondraaglijk geworden is. Op dezelfde manier heeft hij de jonge Justus geholpen zijn onzekerheid te overwinnen. En toen hij ervan overtuigd was dat zijn wrouw haar depressies niet langer de baas was en werkelijk niet langer leven wilde, accepteerde hij haar lijden als uitzichtloos en ondraaglijk, en hielp hij haar te sterven.

Maar ook hier stuiten we op een probleem. Dokter Daan heeft zich door het lijden van zijn vrouw zozeer laten beïnvloeden, dat hij ook zelf lijdt, en zelfs uitzichtloos en ondraaglijk lijdt. Hij heeft immers besloten dat hij dat lijden, dat wil zeggen, het gemis van zijn vrouw, niet langer kan verdragen, en slaat de hand aan zichzelf.

De vraag is daarom of dokter Daan zich niet te veel heeft laten beinvloeden door het lijden van zijn patiënten. Als dat zo is, had ook hij niet kunnen vaststellen in hoeverre het lijden van een ander werkelijk uitzichtloos en ondraaglijk is geworden. Waar Justus zich te veel aan officiële oordelen over het lijden van zijn patiënten vastklampt, heeft dokter Daan zich wellicht te veel laten leiden door de subjectieve pijnbeleving van zijn patiënten. Justus kun je beschuldigen van een gebrek aan empathie, maar dokter Daan kun je een teveel aan inlevingsvermogen verwijten. Zijn relaties met zijn vrouwelijke patiënten zijn ver gegaan, en lijken in strijd te zijn met de gedragscodes van de gezondheidszorg.

Ook daartegen valt het een en ander in te brengen. Ten eerste is het niet duidelijk hoe intiem dokter Daan met zijn vrouwelijke patiënten geweest is. Ten tweede is er geen sprake van dat dokter Daan zijn patiënten tegen hun wil heeft aangeraakt. En ten derde raakt dokter Daan niemand 
willekeurig aan. Er zit een plan achter zijn manier van behandelen. Of beter, aanraken is zijn manier van behandelen. Niemand voelt zich door het "aanraken" belast. Integendeel: alle patiënten van dokter Daan, Justus incluis, voelden zich door hem serieus genomen wanneer hij hen aanrakte. Ze begrepen dat ze met al hun klachten bij hem terechtkonden. Ze beseften dat hij hen in de eerste plaats als mensen zag, en niet alleen als patiënten. '[Z]e laten zich door mij raken,' vertelde dokter Daan aan Steffie, die aan Justus uitlegt dat dat raken dokter Daans 'sterke kant' was: 'daar geloofde hij in, hij wist gewoon dat heel veel pijn en verdriet en angst komt van niet door iemand worden aangeraakt, en als hij je raakte, dan betekende dat misschien niet eens zo veel, en toch betekende het wat, je werd er iemand van, dat is toch zo -.' (Ibid.:166, cursivering in origineel)

Justus vertelt Steffie dat ook hij baat heeft gehad bij dokter Daans manier van behandelen. 'Ik knikte, want ik dacht aan het consult, mijn enige, bij hem, dat mij verliefder op Steffie had gemaakt dan ik strikt gesproken was.' (Ibid.) Als die uitspraak cynisch klinkt, dan neemt Steffie alle twijfels over de waarde van dokter Daans omgang met lijden meteen weg. Dankzij dokter Daans aanraking durfde zij ooit met Justus naar bed te gaan: '[I]k vraag me af of ik, als ik dit niet had gehad met Berend, of ik, met mijn idiote lijf, wel ooit met wie dan ook begonnen was, of ik geen nonnetje in de duinen zou zijn geworden, bang voor grote mannen en voor bouwvakkersgefluit, in ieder geval durfde ik om te beginnen jou te vragen omdat Berend me had geraakt, begrijp je dat?' (Ibid.:167)

Dokter Daan kon de aard van de klachten en het lijden van zijn patiënten herkennen, omdat hij zijn patiënten kende. Zij vertrouwden op zijn oordeel. Alleen in het geval van zijn eigen vrouw is dokter Daan te ver gegaan. Hij kon haar dood niet te boven komen, en heeft daarom besloten ook aan zijn eigen leven een einde te maken. Maar die beslissing benadrukt alleen maar dat zijn manier van aanraken, anders dan een 'ongewenste intimiteit', niets te maken heeft met dwang, of onderwerping van de patiënt aan de wil en willekeur van de dokter. Uit zijn reactie op zijn hulp aan zijn vrouw blijkt dat er tussen hem en zijn "aangeraakte" patiënten altijd een afstand bestaan bleef. Hij was betrokken bij hun lijden, maar hij liet zich er niet door meeslepen. Tegenover zijn vrouw bestond die afstand niet, en daarom ontaardde dokter Daans empathie letterlijk in medelijden.

Toch overschrijdt Dokter Daan niet alleen in het geval van zijn vrouw zijn grenzen. In zekere zin misbruikt hij Justus. Om zelfmoord te kunnen plegen, houdt hij Justus op een afstand. Hij houdt geen rekening met Justus' gevoelens; hij misbruikt zelfs Justus' voorliefde voor principes, regels en voorschriften, en, zo kun je stellen, ook Justus' gevoelens van 
jaloezie. Daardoor komt Justus in moeilijkheden.

In hoeverre kunnen we ten slotte in deze lezing lijden als zinvol beschouwen? Het antwoord op die vraag lijkt simpel: van zin is in alle individuele gevallen geen sprake.

\section{Slotsom}

Dokter Daan en Justus gaan ieder op hun eigen manier met het lijden van hun patiënten om. Dokter Daan richt zich in de eerste plaats op de tweede klacht en probeert door begrip en empathie het lijden van zijn patiënten te verzachten. Justus, die dokter Daans ervaring mist, behandelt alleen de eerste klacht. Het gevolg is dat ten minste twee patiënten liever door dokter Daan dan door Justus behandeld willen worden.

Als we Ons mankeert niets op een historische manier lezen, kunnen we slechts tot de conclusie komen dat de twee verschillende artsen al naargelang hun karakter en ervaring op twee verschillende manieren met lijden omgaan. Elke manier heeft voor- en nadelen. De patiënten in Heimwou waarderen dokter Daans empathische omgang met hun lijden meer dan Justus' al te rationele manier van aanpak. Maar dokter Daan laat zich te zeer meeslepen door het lijden van zijn vrouw en hij manipuleert Justus. Justus op zijn beurt maakt fouten door zijn neiging alles te rationaliseren. Maar dat wil niet zeggen dat hij niet weet hoe belangrijk empathie is. Hij beseft dat hij te weinig aandacht besteedt aan de gevoelens van zijn patiënten en hij realiseert zich dat hij zich als een god gedraagt. Mevrouw Sleutel weet hij ten slotte te kalmeren door op haar tweede klacht - haar angst voor een pijnlijke dood - in te gaan. Je zou kunnen stellen dat Justus' achting voor wetten en regels meer baat heeft dan dokter Daans onconventionele aanpak. Justus gaat niet ten gronde aan het lijden van zijn patiënten. Dokter Daan normalerwijze ook niet. Toen dat toch gebeurde, betrof het niet een willekeurige patiënt, maar zijn eigen vrouw. Toch kunnen ook in de historische lezing van Ons mankeert niets Justus noch dokter Daan objectief vaststellen wanneer het lijden van hun patiënten uitzichtloos en ondraaglijk geworden is.

\section{4}

\section{Het gesprek}

De wet bepaalt dat artsen die euthanasie hebben toegepast, niet vervolgd worden wanneer zij met de betreffende patiënt en met andere artsen gesproken hebben over de toestand van de patiënt. In zijn essays stelt Otten dat iedereen die bij de onnatuurlijke dood van een ander betrokken is, zich schuldig maakt aan de overtreding van het taboe op moord. Wie een ander bij euthanasie betrekt, maakt die ander medeplichtig aan 
het overtreden van dat taboe. Als we Ons mankeert niets als een tragedie lezen, zien we hoe dokter Daan en Justus beiden door hun betrokkenheid bij euthanasie en zelfdoding ten val komen.

Justus is volgens die lezing het prototype van de arts waarvoor Otten in zijn essays waarschuwt: Justus praat meer over dan met zijn patiënten. Als hij met zijn collega's praat over de toekomst van zijn patiënten, meet hij zich een goddelijke macht toe. Hijzelf, de artsen van het ziekenhuis en zijn directe collega"s beschikken immers over leven en dood van de patiënten. Justus doet nog iets waartegen Otten zich in zijn essays weert. Als hij met Verdurmen over patiënt Galesloot spreekt, wordt duidelijk dat ze samen zijn dood voorbereid hebben. Ze betrekken elkaar in een samenzwering, vooral omdat ze niet expliciet toegeven dat ze hun patiënt hebben laten sterven zonder dat deze zijn verzoek om euthanasie heeft herhaald.

Als we de roman echter als een verhaal over de dagelijkse praktijk van een willekeurige Nederlandse arts lezen, moeten we vaststellen dat Justus simpelweg de wet overtreedt. Hij houdt zich niet te veel, maar te weinig aan de regells. Echt diepgaande gesprekken, waarin hij voldoende aandacht schenkt aan de situatie van een patiënt, gesprekken zoals artsen voeren moeten volgens de officiële zorgvuldigheidseisen, voert Justus niet - noch met zijn collega's, noch met zijn patiënten. Met de artsen van het ziekenhuis overlegt hij schriftelijk, als hij al overlegt en niet simpelweg op hun schriftelijke verklaringen afgaat. Met Verdurmen, zijn collega, praat hij kort aan de telefoon over de dood van patiënt Galesloot.

Als Justus wel met zijn patiënten spreekt, doet hij dat het liefst op een strikt rationele manier. In zijn ogen wordt tijdens het ideale consult alleen over medische problemen gesproken. Als de visite bij mevrouw Sleutel emotioneel dreigt te worden, reageert hij geirriteerd. Wanneer de vrouwen in zijn omgeving aandringen op een gesprek met dokter Daan, raakt hij in paniek. Dokter Daan is niet lichamelijk ziek, en lijdt dus officieel niet uitzichtloos en niet ondraaglijk. Justus voorziet dat een gesprek met dokter Daan emotioneel en irrationeel zal zijn. Bovendien zou hij in een gesprek met dokter Daan de rol van toehoorder moeten vervullen hij is immers niet de huisarts van dokter Daan en hij zal niet over officiële medische bevindingen kunnen praten. Dergelijke gesprekken gaat hij uit de weg.

Toch wil dat niet zeggen dat Justus geen emoties heeft, of geen emotioneel gesprek kan voeren. Hij staat zich dergelijke gesprekken niet toe, uit onzekerheid, of omdat hij met zijn gedachten bij zijn vriendin is. In het gesprek met mevrouw Sleutel is op enig moment compassie aanwezig, maar zodra die compassie de kop opsteekt, onderdrukt Justus die, verlangend als hij is om naar Steffie te gaan. We mogen ook niet vergeten 
dat Justus toegeeft dat hij zich overmoedig opstelt en dat hij zichzelf schuldig en zijn collega medeplichtig maakt aan moord. Je zou wat dat betreft zelfs kunnen stellen dat hij zich te veel door zijn emoties laat leiden, en dat hij niet rationeel genoeg denkt en handelt. Het zou in alle gevallen zelfs beter zijn geweest als Justus zich meer aan de regels van zijn vak en die van de wet had gehouden. Dan zou hij niet medeschuldig zijn geweest aan de dood van meneer Galesloot. Bovendien zou hij beter naar de klachten van de moeder van de baby met meningitis geluisterd hebben en beter zijn best hebben gedaan om een gesprek met dokter Daan te voeren.

Een consult met dokter Daan zou waarschijnlijk nooit strikt formeel en rationeel zijn, laat staan verhullend. Als de reactie van mevrouw Sleutel typisch is voor dokter Daans patiënten - en er zijn voldoende redenen om dat aan te nemen - dan is een consult met dokter Daan altijd persoonlijk en informeel geweest. Dokter Daan heeft oog voor het feit dat het dagelijkse leven een weefsel is van emoties en betrekkingen, zoals Otten het noemt. (Otten 1995a) Omgekeerd weten dokter Daans vrouwelijke patiënten blijkbaar ook wat hém beweegt. Ze zijn allemaal bang dat hij zelfmoord zal plegen. Ook daarin onderscheidt dokter Daan zich van Justus; hij heeft niet alleen oog en oor voor de gevoelens en emoties van zijn patiënten, maar hij maakt zijn patiënten ook deelgenoot van de zijne.

Maar ook hier kunnen we ons weer afvragen of dokter Daan niet te ver gaat. Overschrijden zijn consultaties niet de grenzen van het consult, juist omdat ze zo persoonlijk zijn? Maakt hij daarom niet zijn patiënten medeplichtig aan zijn zelfdoding?

Van het medeplichtig maken wan zijn collega lijkt in eerste instantie geen sprake. In Justus' empathische vermogens lijkt dokter Daan net zo weinig vertrouwen te hebben als mevrouw Sleutel. Maar die schijn bedriegt, zoals we hebben gezien. Dokter Daan manipuleert zijn jongere collega. Wanneer hij Justus vraagt om op de dag van zijn dood 's middags om half vier langs te komen, weet hij dat zijn opvolger precies zal doen wat hij hem vraagt. Door Justus niet expliciet van zijn plannen op de hoogte te brengen, maakt hij hem nog meer medeplichtig aan zijn dood dan wanneer hij dat wel had gedaan. Als dokter Daan open kaart had gespeeld, had Justus de kans gehad hem van zijn voornemen af te brengen. Steffie daarentegen wordt door dokter Daan volledig in vertrouwen genomen, zo lijkt het tenminste. In de nacht van de achtentwintigste op de negenentwintigste maart van het vorige jaar, een jaar na de clood van Evelien Daan, heeft zij dokter Daan gezelschap gehouden en met hem gepraat. Zo heeft ze zijn zelfdoding verijdeld. 'Hij heeft me binnengelaten,' vertelt ze Justus, 'en alleen omdat ik er was, omdat er iemand 
luisterde, haalde hij de nacht. En ik zei steeds maar dat ik hem begreep. Het was ook te begrijpen. Je kunt van iemand anders veel te goed begrijpen dat zij dood will.' (Otten 1994d:174)

Ook dit jaar is Steffie in de nacht van de achtentwintigste op de negenentwintigste naar dokter Daan gegaan. We weten echter niet of zij met hem over zijn plannen gepraat heeft. Hij wil niet met haar aan de tellefoon spreken, en hij antwoordt niet op de brief die ze bij hem in de bus gooit. "s Nachts gaat ze weliswaar naar hem toe, maar wat ze bespreken, komen we niet te weten. Justus, die aan de slaapkamerdeur luistert, hoort haar alleen twee keer hard 'nee' roepen. 'Hij wil niet op andere gedachten gebracht worden," raadt hij, 'zelfs niet door iemand die van hem houdt.' (Ibid.:137) Dokter Daan is dit keer vastberaden te sterven en wil daarom niet met zijn vrienden en kennissen over zijn plannen praten. 'Hij wil ons zichzelf besparen,' zegt Justus. (Ibid.:138) Dokter Daan heeft al eerder geweigerd met anderen te spreken: noch Hilde, noch de dochters van mevrouw Sleutel, noch de vrouw van de slager krijgen hem te zien.

Steffie en Hilde hoeven we volgens deze lezing, anders dan volgens de tragische lezing, niet als medeplichtigen aan moord te beschouwen. $\mathrm{Z}_{\mathrm{ij}}$ proberen daadwerkelijk dokter Daan te redden. Dat wil echter niet zeggen dat ze niet betrokken zijn. Integendeel. Als dokter Daan een regulier consult met Justus of een andere arts gehad had, waren de gevolgen minder verstrekkend geweest. De persoonlijke gesprekken die hij met Steffie en Hilde gevoerd heeft, maken dat ze zwaarder getroffen worden door zijn dood dan wanmeer hij niet met hen gesproken had. Bovendien bepaalt hun emotionele band met dokter Daan hun verhouding met Justus. Hilde komt erachter dat Justus vermoedt dat zijn voorganger plannen heeft om een eind aan zijn leven te maken, maar niets daartegen onderneemt. Ze haat hem daarom. Steffie verdwijnt na dokter Daans zelfdoding. In het geval van zijn zelfdoding, kun je daarom zeggen, doet dokter Daan te veel wat Justus te weinig doet. Hij betrekt Hilde en Steffie zozeer bij zijn gevoelens, dat zijn dood niet alleen hún leven, maar ook dat van Justus kapotmaakt. Tegelijkertijd negeert hij hun gevoelens, zoals hij dat nooit eerder heeft gedaan. In zijn verslag klaagt Justus zijn oudere collega aan, omdat die bewust en opzettelijk Steffie heeft laten lijden:

$U$ weet precies hoe het is om iemand van wie je houdt porie voor porie te laten gaan. En niemand heeft al die tijd, de hele dag, deze lange, godgeklaagde achtentwintigste maart, beter geweten waarom u wilde gaan dan zij. Toch hebt $\mathrm{u}$ haar niet open gedaan. [... .]

U kon van niemand meer houden, zelfs van Steffie niet.

Waarom, dokter Daan, heeft u niet begrepen dat Steffie u begreep? 
Alles wat wij weten wijst richting dood.

Maar begrijpen?

Heeft u Steffie begrepen?

Beseft $u$ wie zij yoor $u$ wilde zijn?

Alles wat we weten wijst richting dood.

Als dat niet zo was, waarom zijn we dan, met z'n allen, zo allesvermoedend geweest de hele dag, warom was Heimwou zo aanzwellend bang?

(Ibid.:180-181)

\section{Slotsom}

Wie een ander bij euthanasie betrekt - een patiënt een arts, of een arts zijn of haar collega's - maakt die ander volgens Otten medeplichtig aan de overtreding van het taboe op moord. De zorgvuldigheidseis die betrekking heeft op het consult tussen arts en patiënt enerzijds, en gesprekken tussen artsen anderzijds maakt daardoor zowel artsen als patiënten tot tragische personages. Dat zien we als we Ons mankeert niets als tragedie lezen: Justus en dokter Daan komen beiden door dokter Daans zelfdoding ten val.

Als we de roman op een historische manier lezen, komen we tot een andere conclusie. Waar de ene arts te weinig met zijn patiënten en zijn collega's praat, praat de ander te veel. Als hij zich aan de zorgvuldigheidseisen gehouden had, zou Justus niet schuldig zijn aan moord op patiënt Galesloot (wat hij naar de regel van de wet wel is) en zou hij de Verklaring van Overlijden van doker Daan niet verkeerd ingevuld hebben. Dokter Daan zou de mensen in zijn omgeving minder ongelukkig gemaakt hebben als hij hen niet bij zijn plannen betrokken had. Maar ook als Justus met zijn patiënten over euthanasie praat - zoals met mevrouw Sleutel en zich in dat opzicht aan de wet houdt, schiet hij tekort. Hij praat immers alleen met mevrouw Sleutel om een einde aan zijn visite te maken en om te voorkomen dat zij zich tot dokter Daan wendt. Voor dokter Daan geldt dat hij zonder met Justus te praten zijn jonge collega bij zijn zelfdoding betrekt. Het naleven van de zorgvuldigheidseisen zou de protagonisten veel leed bespaard kunnen hebben. Als dokter Daan met Justus over zijn voornemen gesproken had, had die misschien zijn dood voorkomen kunnen hebben.

\section{$5 \quad$ Het belang van toekomstplannen}

Een arts die euthanasie toepast op een wilsonbekwame patiënt, mag dat alleen doen als er een wilsverklaring van de betreffende patiënt voorligt. 
Otten geeft in zijn essays blijk van ernstige bezwaren tegen dergelijke verklaringen. Schriftelijke wilsverklaringen, stelt hij, doen mensen denken dat ze de toekomst bepalen kunnen. Het idee van een beheersbare toekomst komt voort uit het wetenschappelijk ideaal van een door abstracte ideeèn beheersbare wereld en staat, aldus Otten, haaks op de complexe werkelijkheid. Dat zou op zich niet zo problematisch zijn, ware het niet dat wilsverklaringen inderdaad de toekomst bepalen kunnen. Wie een euthanasieverklaring heeft ondertekend, daarna ongeneeslijk ziek wordt en bovendien wilsonbekwaam, loopt de kans tegen zijn of haar wil gedood te worden. Volgens de wet mag een arts euthanasie uitvoeren bij een patiënt die een wilsverklaring heeft getekend voordat hij in een toestand rakte waarin hij "niet langer in staat is zijn wil te uiten". Otten waarschuwt met klem tegen het gevaar dat iemand die niet in staat is zijn verklaring in te trekken ongewild door euthanasie sterft. (Otten 1995b)

In Ons mankeert niets laat Otten zien waarop het onvoorwaardelijk geloof in schriftelijke verklaringen uitlopen kan. Meneer Galesloot sterft, zonder dat hij uitdrukkelijk heeft kunnen bevestigen dat hij dood wil. Zijn overlijden komt, zo blijkt uit de rouwkaart die Justus op negenentwintig maart ontwangt, voor zijn familie onverwacht. Als we de roman als een tragedie lezen, zien we dat het geloof in de maakbaarheid van de toekomst inderdaad leidt tot de overtuiging dat artsen over de levens van hun patiënten mogen beschikken en hen mogen laten sterven wanneer zij - de artsen - dat het beste achten. Zo toont Justus' beslissing om meneer Galesloot een dodelijke injectie te geven aan dat een wilsverklaring een arts de macht in handen kan geven over leven en dood te oordelen, een macht die volgens Otten te groot voor mensen is. Die beslissing onderstreept bovendien Justus' vertrouwen in de rationaliteit van een geschreven verklaring, of beter, zijn vlucht in het abstracte. Justus onderdrukt zijn angst voor de 'instabiele, weifelachtige ziel met een neiging tot worsteling om betekenis' (Otten 1995b:46) met een ferm geloof in het belang van een officiële, geschreven verklaring.

Als we Ons mankeert niets als historie lezen en ons concentreren op de verschillende situaties waarin de protagonisten zich bevinden, moeten we vaststellen dat meneer Galesloot te kennen heeft gegeven dat hij een zachte dood wil sterven, en dat hij vermoedelijk ook zonder een extra injectie al spoedig gestorven zou zijn. Er is geen reden om aan te nemen dat hij met zijn eerdere vraag om euthanasie aan het worstelen geslagen was. Zo bezien kun je zeggen dat zijn verklaring hem behoed heeft voor ernstiger lijden.

In deze lezing moeten we bovendien vaststellen dat er een geruststellende werking kan uitgaan van een verklaring over de toekomst, al dan 
miet geschreven. Als Justus mevrouw Sleutel belooft dat hij haar zal helpen, kalmeert ze onmiddellijk. Ook al zou mevrouw Sleutel met dez̄e belofte gevaar lopen zich aan Justus' tijdsplanning over te leveren, dan heeft ze toch nog baat bij het idee dat hij zal zorgen dat zij zonder al te veel pijn en angst sterven zal. Een verklaring over de toekomst, blijkt uit dit voorbeeld, kan ons het heden op een aangenamere manier doen beleven, vooral wanneer we het gevoel hebben dat wij zonder die verklaring een ondraaglijke tijd tegemoet gaan.

Justus' eigen schriftelijke verklaring - zijn verslag van de twee dagen in maart - heeft een vergelijkbare werking. Ook al gaat het hier om een verklaring achteraf, en heeft hij er voor de toekomst weinig plezier aan, toch helpt die verklaring hem de gebeurtenissen te begrijpen en te aanvaarden.

Niettemin kleven er nadelen aan de manier waarop Justus omgaat met de verklaringen van meneer Galesloot en mevrouw Sleutel. Hoewel Justus in beide gevallen doet wat zijn patiënten van hem vragen, gebruikt hij hun verklaringen eerder als alibi dan als uitgangspunt. Meneer Galesloot krijgt een overdosis pijnstiller op het moment dat het Justus het best uitkomt, en Justus' belofte aan mevrouw Sleutel om voor een zacht einde te zorgen is eerder ingegeven door zijn afgunst jegens dokter Daan dan door zijn wens haar te helpen. Je kunt argumenteren dat beide patiënten hoe dan ook voordeel hebben bij Justus" beslissing hen te laten sterven, maar daartegenover staat dat Justus' houding niet bepaald vertrouwen inboezemt. $Z i j n$ eigengereide beslissingen kunnen er evengoed toe voeren dat mevrouw Sleutel, of iedere andere uitbehandelde patiënt, eerder sterft dan zij of hij gewild had. We mogen bovendien niet vergeten dat noch meneer Galesloot, noch mevrouw Sleutel een schriftelijke wilsverklaring getekend heeft. Dat ze sterven wilden, horen we alleen van Justus.

Wat dokter Daan betreft: uit het verhaal blijkt niet dat hij ooit met wilsverklaringen te maken gehad heeft. Als hij zelfmoord pleegt, schrijft hij van tevoren geen verklaring over zijn voorgenomen dood. Dat, zou je kunnen zeggen, is zijn kracht - hij bepaalt zelf wanneer hij sterft. Hij laat zijn toekomst niet bepalen door een geschreven verklaring. Justus' onrust over de voorgenomen zelfdoding komt voort uit het ontbreken van een verklaring. Zonder een geschreven verklaring mankeert dokter Daan officieel niets. Dat geeft Justus een excuus om niet in te grijpen. Aan de andere kant heeft dokter Daan natuurlijk wel degelijk een verklaring over zijn voorgenomen zelfdoding afgegeven, zij het niet schriftelijk. Hij heeft Steffie verteld dat hij niet langer leven wilde, en zijn afspraak met Justus heeft hetzelfde effect als een officiële aankondiging. Het verschil is dat die afspraak Justus de mogelijkheid geeft te ontkennen dat hij weet 
dat dokter Daan dood wil. Het ontbreken van een duidelijke verklaring zorgt in dit geval voor meer verwarring dan wanneer dokter Daan zich expliciet over de toekomst uitgelaten had.

Mevrouw Sleutel wil eerst niet met Justus, maar wel met dokter Daan spreken, omdat zij zeker weet dat de laatste haar helpen zal. Daaruit blijkt dat ook dokter Daan weet heeft van de geruststellende kracht die een uitspraak over de toekomst kan hebben. Hetzelfde geldt voor zijn eigen vrouw. Dokter Daan belooft haar dat hij een einde maken zal aan haar lijden. Die belofte heeft een ongewone uitwerking; ze versterkt de verhouding tussen Evelien en haar man. Steffie vertelt Justus hoe dat in zijn werk ging:

Hij beschikte over de medicijnen, zei Steffie. Dat heeft hij me verteld. Ik deed wat zij wilde, zei hij. Banger dan voor de dood was zij voor het leven. Ze was uitbehandeld. Dat woord gebruikte hij, dat was toen net uitgevonden. Ze kon niet meer. En Berend zei: als ze ooit van me heeft gehouden, dan was het omdat ik haar nu hielp.

(Otten 1994d:173)

Dokter Daan is een expert in het doen van uitspraken die zijn patiënten vertrouwen in de toekomst geven. Daarbij is het irrelevant of die uitspraken waar zijn of niet; het gaat hier simpel en alleen om het gegeven dat bepaalde uitspraken ons de mogelijkheid bieden zin te geven aan de tijd die voor ons ligt, zonder dat we per se in de toekomst zullen doen wat we ons op een bepaald moment voornemen. Die mogelijkheid geeft tegelijkertijd betekenis aan het heden. Toen Steffie als jong meisje dokter Daan vroeg of ze vanwege haar geringe lengte ooit een verhouding met een man krijgen zou, stelde hij haar onmiddellijk gerust, zelfs al besefte ze dat hij iets zei dat niet echt waar was:

- ik hoopte dat hij naar me zou kijken en iets van me zeggen zou, niet dat ik mooi was, niet per se iets vleiends, maar, gewoon, wat een man zou zeggen die me naakt zag, iets waars, kun je dat begrijpen? Maar hij ademde alleen maar, met die korte ademstootjes, weet je nog wel, en ik voelde dat schijfje van dat luisterding naast mijn ruggegraat, en toen zei hij dat ik op de behandeltafel moest liggen, en daar luisterde hij nog een tijdje, terwijl ik dus helemaal niks had, dat wist ik ook wel-en ik zal zijn blik nooit vergeten, hij heeft grote, zachte ogen met wallen waarvan de linker soms een beetje trekt als hij moe is, of opgewonden, en hij keek, hoe zeg ik het, hulpeloos, alsof er iets was wat hij niet wou. En hij kwam overeind en liet het luisterding zakken en zei: als je godverdomme ook maar één 
seconde denkt dat jouw borstjes te klein zijn, draai ik je in hoogst eigen persoon je nek om, als een krielkip - [...]-en toen legde hij zijn rechterhand eerst op mijn linkerborst, die, zoals ik daar lag, natuurlijk volkomen denkbeeldig was, en daarna heel voorzichtig op mijn rechter. Zo'n beetje zoals je je hand op een fontanel legt. En hij keek weer vreselijk hulpeloos, ten hemel zowat; alsof hij zichzelf ten zeerste bekloeg, en toen kuste hij me. Toffeerook, daar smaakte hij naar. Nogal best tamelijk lang. En toen hij weer overeind kwam zei hij: jou mankeert niets.

(Ibid.: 163-164)

Maar ook deze behandeling lijkt een schaduwkant te hebben. Dokter Daans vermogen zin te geven aan Steffies leven, maakt dat Steffie bepaalde dingen doet om ze door dokter Daan betekenis te laten geven. Ze lijkt zich daardoor afhankelijk van zijn oordeel te maken. En sterker nog: dokter Daans oordeel over een gebeurtenis lijkt voor haar soms belangrijker te zijn dan de gebeurtenis zelf. Zo vertelt Steffie dat ze dikwijls met iemand naar bed gaat om dokter Daan daarover later te kunnen vertellen. De verklaring wordt zo voor haar waardevoller dan de handeling. Omgekeerd, zegt ze, gold hetzelfde:

$[\ldots]-$ en het gekke is, zei Steffie, $[. .$.$] dat het heel vaak zó was dat ik$ met iemand wilde omdat ik dacht aan wat ik dokter Daan daarna zou vertellen, kun je dat begrijpen, en ik geloof dat het met hem ook ongeveer zo was, we gingen wat we meemaakten, niet alleen in bed, maar eigenlijk toch vooral in bed, beschouwen als iets wat we voor elkaar deden [...].

(Ibid.:166)

Een vergelijking met een schriftelijke wilsverklaring is gauw gemaakt. In beide gevallen kunnen de woorden en het verhaal als werkelijker en belangrijker beschouwd worden dan de concrete werkelijkheid. Dokter Daans vermogen betekenis te verlenen, makt Steffie van hem afhankelijk: bepaalde handelingen krijgen voor haar pas zin als hij zijn zegen heeft gegeven.

Toch geeft ook dit voorbeeld aan waarin de kracht van verklaringen zit. De verhouding tussen dokter Daan en Steffie is uiteraard meer dan die tussen een arts en een patiënt - dokter Daan en Steffie hebben een amoureuze relatie. Maar juist hun relatie en het einde daarvan laten zien hoe belangrijk het bespreken van toekomstplannen zijn kan. Dokter Daan verbreekt de vertrouwelijkheid tussen hen beiden wanneer hij Steffie niet op de hoogte stelt van zijn plannen. $\mathrm{Zij}$ is zo ontzet over zijn 
weigering zijn gevoelens met haar te delen, dat ze na zijn dood verdwijnt. Justus aan de andere kant helpt dokter Daan te sterven, omdat dokter Daan hem niet op de hoogte brengt van zijn zelfdodingsplannen. Dokter Daan stelt Justus immers niet in staat hem te helpen of van zijn voorne-

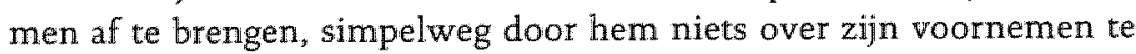
vertellen. Dokter Daan manipuleert zijn omgeving door niemand openlijk op de hoogte te brengen van zijn plannen. Had hij dat wel gedaan, dan had de toekomst van Justus, Steffie en Hilde er waarschijnlijk heel wat aangenamer uitgezien.

\section{Slotsom}

Verklaringen over de toekomst hoeven we niet per se als een uitdrukking van hoogmoed te beschouwen, zoals Otten dat doet. De dood van meneer Galesloot voorkomt waarschijnlijk ernstiger lijden en Justus' belofte aan mevrouw Sleutel werkt voor haar als een geruststelling. Die belofte neemt haar angst voor de dood voor een groot deel weg.

Maar ook zonder verwijzing naar een 'buitenmenselijke macht' moeten we vaststellen dat wat Justus doet, niet acceptabel is. Hij handelt meer in zijn eigen belang dan in dat van zijn patiënten. Hun verklaringen gebruikt hij om zijn beslissingen te legitimeren.

Van dokter Daan kun je dat niet zeggen. Hij helpt zijn vrouw, voor zover we dat kunnen nagaan, alleen omdat zij werkelijk sterven wil. Maar in dit geval zijn de gevolgen zo mogelijk nog desastreuzer. Als resultaat van zijn hulp aan zijn vrouw wil hij ook zelf niet verder leven. Anders dan Justus" patiënten praat hij niet over zijn plannen, behalve met Steffie, en met haar nog maar ten dele. Het gevolg is dat iedereen in onzekerheid verkeert en dat Justus zich uiteindelijk voor de dood van zijn voorganger verantwoordelijk voelt. Openheid van zaken, gesprekken en geschreven wilsverklaringen hadden dat alles voorkomen kunnen. Waar je in de tragische lezing het te veel an zuiver rationele beslissingen betreuren kan, doet de historische lezing je naar meer rationaliteit verlangen.

\section{Samenvatting en conclusie}

Als we Ons mankeert niets lezen als de geschiedenis van twee willekeurige huisartsen en hun naasten, kunnen we vaststellen dat euthanasie en hulp bij zelfdoding in bepaalde gevallen groter lijden voorkomen. Toch roept ook deze lezing vragen op. Justus laat zich hoe dan ook te zeer leiden door zijn angsten en onzekerheden. Daardoor toont hij te weinig respect voor de wensen van zijn patiënten en overlegt hij nauwelijks of niet met hen en zijn collega. Het lijden van een patiënt is in zijn ogen pas 
uitzichtloos en ondraaglijk wanneer dat officieel vastgesteld is, niet wanneer de patiënt zijn of haar lijden als ondraaglijk ervaart. Hij doet alles wat de wet op euthanasie moet voorkomen; hij misbruikt zijn macht.

De handelwijze van dokter Daan laat zien dat artsen op een open wijze om kunnen gaan met hun patiënten, en dat er een andere manier bestaat om op vragen betreffende euthanasie en hulp bij zelfdoding in te gaan. Op die manier ontstaat een genuanceerder beeld van euthanasie en hulp bij zelfdoding. Dokter Daan richt zich niet alleen op de eerste, lichamelijke klacht van zijn patiënten, maar ook op de tweede, meer psychologische klacht. Hij heeft aandacht voor onuitgesproken angsten en wensen. Hij beoordeelt de toestand van een patiënt aan de hand van de uitspraken van die patiënt en van zijn eigen bevindingen. Waar Justus het lijden probeert te objectiveren, kijkt dokter Daan naar de subjectieve pijnervaring. Zijn patiënten voelen zich vrij om met hem over euthanasie te praten, en hij respecteert hun beslissingen.

Maar dokter Daan is niet altijd de ideale arts. Hij maakt een fout door zijn eigen vrouw te behandelen. Hij kan geen afstand van haar problemen nemen. Hij helpt haar te sterven, en realiseert zich te laat dat hij zonder haar niet wil leven. Om zelfmoord te plegen, overtreedt hij zijn eigen principes: hij praat niet met Steffie en hij manipuleert Justus. Dergelijk gedrag onderstreept het belang van de wet op euthanasie. Dokter Daan laat zien hoe belangrijk het is acht te slaan op de achtergrond, de situatie en de gevoelens van een patiënt. Hij personifieert zo de ideale toepassing van de zorgvuldigheidseisen van de wet op euthanasie. Zodra hij die eisen in de wind slaat, gaat het mis. Dan maakt hij een einde aan het leven van zijn vrouw, pleegt zelfmoord, en beinvloedt daardoor niet alleen de levens van Steffie en Justus, maar ook van Justus' vrouw en kinderen.

Als je Ons mankeert niets op een historische manier leest, gaat de roman over de verhouding of, zo men wil, de dynamiek tussen mensen. Zo gelezen laat het boek zien dat de problemen die bij euthanasie ontstaan, anders dan Ottens essays suggereren, niet door het noodlot bepaald worden, maar door de manier waarop twee bepaalde artsen met elkaar en met hun patiënten omgaan.

Welke lezing geeft ten slotte een concreet antwoord op de vraag wat je moet doen als je weet dat iemand dood wil? En wat leren de beide lezingen over de verhouding tussen wet en werkelijkheid?

Beide lezingen maken duidelijk dat zelfbeschikking een relatief begrip is. De tragische lezing laat zien dat zelfbeschikking niet bestat. De historische lezing toont dat zelfbeschikking niet mogelijk is als er een te grote afstand bestaat tussen patiënt en arts. Maar een te grote betrokkenheid tussen beiden is evenmin aan te raden. Ook die beïnvloedt de mate waar- 
in een patiënt over zijn eigen leven kan beschikken.

Beide lezingen leren dat lijden niet objectiveerbaar en niet meetbaar is. De mate van het lijden kan afhankelijk zijn van de situatie waarin een patiënt zich bevindt. Justus' gewoonte om lijden alleen volgens officiele maatstaven te erkennen, voert niet alleen tot de vroegtijdige dood van. een van zijn patiënten, maar vergroot ook de afstand tussen hem en zijn patiënten.

De eerste lezing leert ons dat het onmenselijk is als artsen alleen algemene, abstracte normen hanteren als ze ervaren dat een patiënt sterven wil. Deze lezing maant ons iedere gedachte aan euthanasie en hulp bij zelfdoding uit te bannen. Ze laat zien dat je maar beter nooit geconfronteerd kunt worden met de vraag wat je moet doen als je weet dat iemand sterven wil. Maar deze lezing maakt ook duidelijk dat niemand gebaat is met het toepassen van algemene regels zonder aandacht voor de concrete situatie waarin artsen en patiënten zich bevinden. Rationaliteit zonder gevoell leidt in het verhaal tot de waarschijnlijk te vroege dood van meneer Galesloot; beloftes aan mevrouw Sleutel die niet zo gemeend zijn als zij denkt; angst bij de vriendinnen van dokter Daan; dokter Daans dood en Justus' verlies van vrouw, vriendin en, misschien, zijn baan.

De historische lezing laat zien dat het niet ongevaarlijk is wanneer artsen alleen afgaan op hun gevoel en de situatie waarin zij en hun patiënten zich bevinden. Zowel de tragische als de historische lezing laat zien hoe belangrijk aandacht voor de concrete werkelijkheid, intermenselijkheid en vertrouwelijkheid is. Hoe we het boek ook lezen, het brengt steeds tot uitdrukking dat artsen er het beste aan doen de algemene wet te volgen en tegelijkertijd de concrete werkelijkheid niet uit het oog te verliezen. Eenzijdigheid voert in beide lezingen tot problemen.

Dat laatste geldt ook voor de lezingen zelf. Als we een antwoord willen vinden op de vraag die het boek stelt, leert de eerste lezing dat we ons in principe altijd ver moeten houden van mensen die sterven willen. De tweede lezing leert ons in feite alleen iets over het gedrag en de twee karakters van twee bepaalde artsen in een bepaalde situatie. In de ene lezing ligt te veel nadruk op de wet; in de andere is te veel aandacht voor de concrete werkelijkheid alleen. Noch de tragische lezing, noch de historische leert ons om te gaan met de wet zonder dat daarbij de concrete werkelijkheid veronachtzaamd wordt, en omgekeerd.

Aan het eind van beide lezingen worden we met twee vragen geconfronteerd. De eerste vraag luidt: hoe lossen we de paradox tussen het opvolgen van een algemene wet en het tegelijkertijd in acht nemen van de particuliere situatie van een bepaalde patiënt op zonder een van beide te laten prevaleren? Met andere woorden: hoe gaan we om met de doodswens van een ander zonder wet en werkelijkheid te veronachtzamen? De 
tweede vraag richt zich expliciet op de roman: hoe kan een literaire tekst, gezien de genoemde paradox die de beide lezingen oproepen, ons helpen een antwoord te vinden op de vraag wat we moeten doen als we weten dat iemand sterven wil?

In het volgende hoofdstukkomt de filosofie van Maurice MerleauPonty aan de orde. Zijn werk laat zien dat het particuliere en het algemene niet zonder elkaar bestaan. Merleau-Ponty maakt bovendien duidelijk waarom en hoe een roman ons helpen kan de juiste beslissingen te nemen. In die zin kan het werk van Merleau-Ponty ons helpen de eerste twee lezingen te integreren en te verdiepen en mogelijke antwoorden op bovengestelde vragen te formuleren. 



\section{De filosofie van Maurice Merleau-Ponty}

Justus Loef en Berend Daan zijn de twee hoofdrolspelers in de roman die de schrijver zelf een tragedie genoemd heeft. Het schrijven van de roman, zo blijkt uit Ottens essays en uit verschillende interviews met hem, diende verschillende doelen. Ten eerste wilde Otten demonstreren dat we de werkelijkheid niet kunnen reduceren tot zuiver rationele begrippen en abstracte noties. Met zijn boek wilde hij aannemelijk maken dat wij ten onrechte denken dat we leven en dood kunnen beheersen en bepalen. Sinds Plato, zegt hij, gaan we er vanuit dat al onze beslissingen en handelingen op een strikt rationele manier tot stand komen. Het gevolg is dat we in een vrije wil zijn gaan geloven. Ten tweede wilde Otten aantonen dat alleen de literatuur de 'onkraakbaarheid' van de werkelijkheid tot uitdrukking brengen kan. Ten derde schreef hij Ons mankeert niets om zijn standpunt over de legalisering van euthanasie te verwoorden. Bij het schrijven van de roman wilde hij nagaan of er een dood bestaat die niemand belast. (Albrecht 1997) Die wens culmineerde in een vraag: wat doe je als je weet dat iemand dood wil?

Op die vraag lijkt Otten in zijn essays geen eenduidig antwoord te geven. Wie met die vraag geconfronteerd wordt, is, zo schrijft hij, een tragisch personage. De al dan niet vrijwillige betrokkenheid bij een "buitenmenselijke oplossing' als de dood, maakt iedereen hoe dan ook medeplichtig aan de overtreding wan een taboe. Afgaande op Ottens essays kun je dus tot de conclusie komen dat Ons mankeert niets laat zien dat artsen zich, ook als ze geen gevolg geven aan de vraag van een patiënt om euthanasie, schuldig maken aan betrokkenheid bij moord.

De roman kan echter op verschillende manieren gelezen worden, zoals in de vorige hoofdstukken betoogd werd. Volgens de ene lezing belichaamt Justus het tragisch personage dat denkt dat hij op een zuiver rationele manier om kan gaan met zijn patiënten en met euthanasie. Hij komt ten val, omdat hij niet will inzien dat het leven allesbehalve ratio- 
neel, overzichtelijk, begrijpelijk en beheersbaar is. Ook dokter Daan maakt zich schuldig aan hoogmoed, omdat hij zijn vrouw bij haar zelfdoding helpt. Twee jaar later doodt hij ook zichzelf. Ons mankeert niets kunnen we dus als een warschuwing beschouwen tegen een al te rationalistische en een hoogmoedige kijk op ziekte, dood en euthanasie. Tegelijkertijd maant het boek volgens deze lezing ons het taboe op moord te respecteren en de dood te beschouwen als een buitenmenselijke aangelegenheid. De algemene, buitenmenselijke wet van het lot is in deze lezing belangrijker dan de concrete werkelijkheid: wie een ander doodt of bij zelfdoding helpt, overtreedt het taboe en komt ten val.

Ons mankeert niets kan ook gelezen worden als een verhaal over de dagelijkse ervaringen van een willekeurige, contemporaine huisarts in een Nederlands dorp. Als je het boek vanuit dat perspectief leest, biedt het zicht op een minder regelgerichte omgang met euthanasie. Vooral dokter Daan heeft oog voor de angsten en wensen van zijn patiënten - voor hem is de concrete ervaring belangrijker dan een analyse of een abstracte wet. Dokter Daan laat zich volgens deze lezing in de eerste plaats door zijn emoties leiden. Maar ook deze lezing stelt ons voor een probleem. Wie, zoals dokter Daan en in zekere zin ook Justus, de dagelijkse ervaring belangrijker vindt dan zuiver rationele overwegingen en een algemene wet, doet dingen die evenmin acceptabel zijn. Justus bijvoorbeeld makt een einde aan het leven van meneer Galesloot zonder overleg vooraf met diens familie en een collega-arts, waardoor de dood van meneer Galesloot in alle opzichten onverwacht is. Dokter Daan helpt, zonder enig overleg met een collega, zijn vrouw een einde aan haar leven te maken. Daardoor wil hij ook zelf niet langer leven. Met zijn zelfdoding ten slotte maakt hij iedereen in zijn omgeving ongelukkig, Justus incluis.

Beide lezingen laten zien dat een wet zonder de werkelijkheid hol is, en dat de werkelijkheid bij regels gebaat is. Daarom zouden we de de twee lezingen in elkaar op moeten laten gaan. Pas dan zouden we een werkbaar antwoord kunnen vinden op de vraag wat je moet doen als je weet dat iemand sterven wil.

Om de twee lezingen te integreren en te verdiepen, wordt in dit hoofdstuk de filosofie te hulp geroepen. Dat lijkt in eerste instantie haaks te staan op Ottens overtuiging. Volgens Otten theeft de filosofie zich sinds Plato immers volkomen losgemaakt van de concrete ervaring. Ottens kritiek op filosofie en wetenschap past echter ook zelf binnen een filosofische stroming. Deze stroming weert zich tegen de waarheidsaanspraak van het traditionele, analytische denken en concentreert zich op de ervaring die voorafgaat aan de analyse. Een van de exponenten van die stroming is de Franse filosoof Maurice Merleau-Ponty (1908-1961). Merleau-Ponty bekritiseert in zijn geschriften het belang dat de traditionele 
filosofie sinds Descartes hecht aan de abstrahering van de concrete ervaring, de analyse en de theorie. De concrete ervaring noemt hij ambigu, omdat zij een twee-eenheid is van zinneming en zingeving. Ook de kennis van die ervaring noemt hij ambigu. De filosofie beschouwt hij als een methode, niet als een gedachtestelsel. Filosofie en literatuur vullen elkaar aan, zegt hij; literatuur is een belangrijk middel om inzicht te krijgen in de structuur van de werkelijkheid. Een roman, schrijft Merleau-Ponty in Phénoménologie de la perception, is geen analyse van de werkelijkheid, maar dient evenmin als spreekbuis van de schrijver. Een roman brengt net als alle andere kunstwerken de concrete ervaring in al haar ambiguiteit direct tot uitdrukking. Zo schrijft hij:

Wat de roman betreft, deze laat zich weliswaar samenvatten, en de 'ideeën' van de romanschrijver laten zich weliswaar abstract formuleren, maar deze begripsmatige betekenis is aan een omvattender betekenis ontnomen, zoals het signalement van een persoon aan de concrete aanblik van zijn fysionomie is ontnomen. Het is niet de taak van de romanschrijver om ideeën uiteen te zetten of zelfs maar karakters te analyseren, maar om zonder enig ideologisch commentaar een intermenselijk gebeuren weer te geven en dit zó te laten rijpen en schitteren, dat elke verandering in de ordening van het verhaal of in de keuze van de perspectieven ook de gehele romaneske zin van het gebeuren zou veranderen. Een roman, een gedicht, een schilderij en een muziekstuk, zijn individuen, dat wil zeggen wezens warbinnen de uitdrukking en het uitgedrukte niet zijn te onderscheiden, waarvan de zin slechts door een direct contact toegankelijk is en die hun betekenis uitstralen zonder hun plaats in de tijd en de ruimte te verlaten.

(Merleau-Ponty 1945:176-177, cursivering in origineel) ${ }^{35}$

Merleau-Ponty richt zich op het kunstwerk om te begrijpen hoe niet alleen de directe ervaring, maar ook abstracte analyses tot stand komen en wat hun waarde en onderlinge relatie is. Hij laat zien waaruit de kennis bestaat die de concrete ervaring ons biedt, en waarom die zo belangrijk is. Merleau-Ponty onderzoekt het ontologisch fundament van de esthetische ervaring. Zo bezien kunnen we Ottens ideeën over lotsbepaaldheid, zijn afkeuring van de legalisering van euthanasie en hulp bij zelfdoding bij het lezen van Ons mankeer niets buiten beschouwing laten. De kennis die het boek ons biedt, hoeft geenszins overeen te komen met de ideeën die Otten volgens zijn essays wil overbrengen. Met andere woorden, als we Ons mankeert niets niet als spreekbuis van Otten beschouwen en het verhaal noch als tragedie, noch als historie lezen, maar, zoals Merleau- 
Ponty het uitdrukt, als de uitdrukking van intermenselijke ervaringen, dan kan het zijn dat we begrijpen waarom en hoe het lezen van een roman ons helpen kan bij het nemen van bepaalde beslissingen.

De opzet van dit hoofdstuk is, net als die van de vorige hoofdstukken, systematisch. Na een inleiding op het denken van Merleau-Ponty vollgt een beschouwing over de zorgvuldigheidseisen uit de wet op euthanasie in het licht van het werk van Merleau-Ponty. Deze beschouwing is gerelateerd aan de vragen die na het lezen van Ons mankeert niets ontstaan zijn.

Merleau-Ponty, schrijft Remigius Kwant in zijn inleiding op het denken van de Franse filosoof, 'stelt [...] zijn wijsbegeerte meermalen voor als een radicale overwinning van het cartesianisme'. Kenmerkend voor het cartesianisme noemt Kwant 'het markante dualisme'. 'Descartes', schrijft hij, 'maakt een scherp onderscheid tussen de denkende geest en de mechanische lichamelijkheid.' (Kwant 1962:19)

Merleau-Ponty weert zich niet alleen tegen het rationalisme, maar ook tegen het empirisme. Beide kentheoretische richtingen, stelt hij, gaan ervan uit dat lichaam en bewustzijn twee verschillende entiteiten zijn. Beide richtingen beschouwen bovendien de reflectie als belangrijker dan de directe ervaring. Kennis ontstaat volgens beide stromingen alleen binnen de rationele analyse, want ondanks hun verschillende uitgangspunten beschouwt zowel het empirisme als het rationalisme de abstracte theorie over de werkelijkheid als belangrijker dan de werkelijkheid zelf. Binnen het rationalisme is de reflectie immers waarachtiger dan de waarm neming, en binnen het empirisme krijgt de ervaring pas in de analyse en de theorie betekenis, ook al worden de modellen waarmee de empirische wetenschappen werken, altijd getoetst aan de werkelijkheid. Binnen de empirische wetenschappen, schrijft Merleau-Ponty, zullen altijd 'de atomen van de fysica werkelijker schijnen dan het historisch-kwalitatieve beeld van de wereld, de fysisch-chemische processen werkelijker dan de organische vormen, de psychische atomen van het empirisme werkelijker dan de waargenomen verschijnselen, de intellectuele atomen, die staan voor de "betekenissen" van de Weense school, werkelijker dan het bewustzijn. Dat zal zo blijven zolang men probeert het beeld van deze wereld, het leven, de waarneming, de geest te construeren in plaats van de ervaring die wij ervan hebben als eerste bron en als laatste instantie van alle kennis ervan te erkennen.' (Merleau-Ponty 1945:31, cursivering in origineel) $)^{36}$ 
De traditonele natuurwetenschappen beschouwen het experiment en de analyse als werkelijker dan de concrete werkelijkheid zelf. Zuiver wetenschappelijke methodes als deductie, inductie, analyse en experiment - dat wat Otten het 'ingenieurlijke denken' noemt - proberen de mens volgens Merleau-Ponty buiten de concrete werkelijkheid te plaatsen. Het gevolg is dat we onze eigen levens voortdurend onderwerpen aan wetenschappelijke of semi-wetenschappelijke denkmodellen en dat we rationele verklaringen bedenken voor iets dat nauwelijks rationeel verklaard kan worden. Het denken in oorzaak en gevolg bijvoorbeeld dwingt ons voortdurend eenduidige oplossingen en verklaringen te zoeken voor problemen of gebeurtenissen die niet eenduidig zijn en geen eenduidige verklaring velen. Bovendien neigen we ertoe die verklaringen belangrijker en werkelijker te vinden dan de gebeurtenissen zelf.

Het traditionele wetenschappelijke denken doet ons de geschiedenis beschouwen als een aaneenschakeling van logisch op ellkaar volgende gebeurtenissen en handelingen, waardoor de densiteit, de complexiteit en de gevarieerdheid van de geschiedenis verloren gaan. Alleen wat aan onze denkmodellen voldoet, heeft tenslotte bestaansrecht en wordt in de officiële analen vermeld. 'De wetenschap;' schrijft Merleau-Ponty in L'oeil et l'esprit, "manipuleert de dingen en ziet ervan af hen te bewonen." (Merleau-Ponty $1964 \mathrm{~b}: 9$ ) $^{37}$ Daarmee is het wetenschappelijke denken ontaard in een 'soort absolute kunstmatigheid' die de mens van individu tot manipulandum degradeert. De mens is daardoor terechtgekomen "in een cultuurstelsel, waarin er van de mens en van de geschiedenis niet langer iets waar of onwaar is, in een slaaptoestand of een nachtmerrie waaruit niets hem nog zou kunnen wekken'. (Merleau-Ponty 1964b:12, cursivering in origineel $)^{38}$

De traditionele filosofische stromingen als rationalisme en idealisme hebben mens en wereld van elkaar gescheiden. Zelfs al blijft de wereld in de denksystemen van Descartes als voorwaarde voor het denken aanwezig, en is voor Kant de zintuiglijke waarneming de voorwaarde voor de mogelijkheid van het denken, dan nog is er sprake van een absolute tweedeling in concrete werkelijkheid en ratio. De ratio is daarbij uiteindelijk van groter belang dan de materie:

Descartes en vooral Kant hebben het subject of het bewustzijn losgemaakt van de wereld, door te laten zien dat ik geen enkel ding als bestaand kan vatten, wanneer ik niet allereerst mijzelf in deze act van vatten als bestaand ervaar. Zij lieten het bewustziin, de absolute zekerheid voor mij van mijzelf, zien als de voorwaarde zonder welke er totaal niets zou zijn, en de act van synthese als het fundament van het gesynthetiseerde. Zeker, de act van synthese is niets 
zonder het schouwspel van de wereld waarvan de samenhang tot stand wordt gebracht; bij Kant is de eenheid van het bewustzijn precies gelijktijdig met de eenheid van de wereld. Ook door de methodische twijfel van Descartes verliezen wij niets, omdat de hele wereld, tenminste in de zin van onze ervaring ervan, weer wordt opgenomen in het Cogito. Zij bezit daarmee zekerheid en wordt slechts voorzien van de aanduiding 'gedachte van.... Maar de betrekkingen tussen subject en wereld zijn niet strikt tweezijdig [...].

(Merleau-Ponty 1945:III, cursivering in origineel) ${ }^{39}$

Reflectie en analyse, zegt Merleau-Ponty, zijn gefundeerd in de prereflectieve ervaring, niet andersom. De concrete ervaring gaat altijd aan de reflectie vooraf. Als we reflectie en analyse als werkelijker beschouwen dan de wereld die daaraan voorafgaat, vergeten we dat we deel titmaken van de wereld voordat we nadenken over de wereld. Als we de reflectie belangrijker achten dan de primordiale ervaring, problematiseren en ondergraven we onze afkomst. Bovendien verliezen we dan onze individualiteit, en daarmee ook ons vermogen om tussen goed en kwaad te kiezen. Abstracte regels en modellen bepalen dan ons wereldbeeld en ons handelen.

Hoe komen we uit die boze droom, en keren we terug naar de concrete werkelijkheid? Merleau-Ponty benadrukt dat het op zich geen probleem is dat we modellen van de werkelijkheid maken. 'Binnen het domein van de wetenschap,' schrijft hij, 'is en blijft het noodzakelijk te begrijpen wat verificatie, nauwgezet onderzoek en kritiek op zichzelf en op de eigen vooroordelen inhouden. [...] De vraag die het moderne denken haar voorlegt, is niet om haar te bekritiseren of om haar een eigen terrein te ontzeggen.' (Merleau-Ponty 2002:14) ${ }^{40}$ Problematisch wordt het pas, wanneer we de modellen als belangrijker beschouwen dan de werkelijkheid. Nog problematischer is het wanneer abstracte ideeën die niet uit de concrete ervaring voortkomen, over de ervaring worden gelegd. Dan vergeten we helemaal dat aan alle reflectie de prereflectieve ervaring voorafgaat. ${ }^{41}$

Maar wat is precies de prereflectieve ervaring?

De prereflectieve ervaring is niet zuiver lichamelijk. De mens, stelt Merleau-Ponty, is een lichaamsubject, een eenheid van lichaam en bewustzijn. Deze eenheid is "een ambigue eenheid - niet vereniging - [...] van lichamelijkheid en subjectiviteit', zoals Kwant het uitdrukt. (Kwant 1962:19) Lichaam en bewustzijn vormen, zoals de twee kanten van een blad papier, een geheel, zonder dat ze volledig met elkaar samenvallen. Het een constitueert niet het ander. Wel ontwikkelen ze zich tegelijkertijd en in eenzelfde beweging. 
De prereflectieve ervaring ontstaat binnen deze eenheid van lichaam en bewustzijn. Dat laten onze dagelijkse handelingen zien: die verrichten we zonder tussenkomst van de reflectie. Dat wil niet zeggen dat ons handelen onbewust is. Ons handelen is intentioneel: het is altijd op iets gericht. We analyseren onze dagelijkse handelingen niet voor we ze uitoefenen. Handelen is niet afhankelijk van reflectie, maar ongekeerd is reflectie wel afhankelijk van de concrete ervaring.

De verhouding tussen het lichaamsubject en de concrete werkelijkheid wordt gekenmerkt door eenzelfde ambigue eenheid. Mensen leven, net als de dingen om hen heen, in de ruimte en in de tijd. Wij ontlenen de betekenis van de wereld aan de wereld zelf, en geven die ook zelf betekenis. We hoeven het denken niet tussen ons en de wereld te schuiven om met de dingen om te kunnen gaan. Het denken over de wereld, de reflectie, vindt altijd achteraf plaats. De prereflectieve ervaring kenmerkt zich door vertrouwen. 'Zolang er niet gevraagd wordt wat het betekent dat wij de wereld zien, weet men wat dat betekent,' schrijft Jenny Slatman. 'Echter, vanaf het moment dat men dit gaat bevragen en articuleren, raakt men verstrikt in een "labyrint van moeilijkheden en contradicties"." (Slatman 1997:277) 42 $^{2}$

Wie nadenkt over de verhouding tussen mens en concrete werkelijkheid, zegt Merleau-Ponty in Phénoménologie de la perception, mag de oorspronkelijke verhouding tussen het lichaamsubject en de concrete werkelijkheid niet uit het oog verliezen. Sterker nog, omdat de traditionele filosofie en natuurwetenschappen de analyse tot absolute waarheid verheven hebben, is het volgens Merleau-Ponty de plicht van de filosofie terug te keren naar de oorspronkelijke verhouding tussen mens en wereid.

Die terugkeer is niet eenvoudig. De mens is gewend bewustzijn en concrete werkelijkheid te denken als twee van elkaar onafhankelijke entiteiten die met elkaar een causale verbintenis aangaan. Het bewustzijn heeft in die relatie een constituerende functie: het denken, zo meent men, ontdekt of bepaalt de ware betekenis van de wereld. In navolging van Husserl beschouwt Merleau-Ponty het als natuurlijk dat de mens zo denkt. Niettemin hebben we hier met een secundaire verklaring te maken. Aan iedere reflectie gaat immers de eenheid van concrete werkelijkheid en lichaamsubject vooraf. Binnen die eenheid vormen het lichaamsubject en de concrete werkelijkheid de twee onlosmakelijke kanten van de ervaring. Het bewustzijn is daarom geincorporeerd in de wereld. Dat maakt de 'natuurlijke houding' begrijpelijk, maar daarom niet juist. Merleau-Ponty noemt de 'natuurlijke houding' daarom ook 'de natuurlijke vergissing': "[...] het is natuurlijk dat het bewustzijn zichzelf verkeerd begrijpt, omdat het bewustzijn altijd het bewustzijn van iets is." (Merleau-Ponty 1942:236)43 
Omdat Merleau-Ponty wil laten zien wat er aan de reflectie voorafgaat, mogen we zijn werk niet als een vastomlijnd wijsgerig systeem zien. De filosofie, zegt hij, moet terugkeren naar het landschap dat de kaart mogelijk maakte. Maar dat wil niet zeggen dat het landschap een betekenisloos gebied is. 'Terugkeren naar de dingen zelf,' schrijft Merleau-Ponty in thet woord vooraf van de Phénoménologie de la perception, 'betekent terugkeren naar deze an de kennis voorafgaande wereld waarvan kennis altijd spreekt en ten opzichte waarvan elke wetenschappelijke bepaling abstract, aanduidend en afhankelijk is, zoals de geografie dat is ten aanzien van het landschap waarin wij allereerst hebben geleerd wat een bos, een weide of een rivier is." (Merleau-Ponty 1945:III, cursivering in origineel) 44

De filosofie is volgens Merleau-Ponty in dat opzicht niet veel anders dan de literatuur of de schilderkunst. Ook de schrijver en de schilder maken zich los van traditionele modellen van de werkelijkheid, en keren terug naar de primordiale, prereflectieve en pretheoretische ervaring. Merleau-Ponty's manier van denken - de nieuwe filosofie, zoals hij het in Phénoménologie de la perception noemt - is een oneindige dialoog of overdenking. Die nieuwe filosofie, zegt hij, 'is een moeizame arbeid zoals het werk van Balzac, van Proust, van Valéry of van Cézanne - door dezelfde stijl van aandacht en verwondering, door dezelfde eis van bewustzijn, door dezelfde wil om de zin van de wereld of van de geschiedenis in haar wording te vatten'. (Merleau-Ponty 1945:XVI) ${ }^{45}$

De schrijver, de schilder en de filosoof keren terug naar het moment waarop betekenis ontstaat: binnen de ambigue verhouding tussen het lichaamsubject en de werkelijkheid. Merleau-Ponty stelt dezelfde eis aan de filosoof als aan de kunstenaar: het denken moet, net als de kunst, in beweging zijn. 'Kunst,' zegt hij in een lezing over film, "is niet bedoeld om nieuwe ideeën ten toon te stellen en [...] contemporaine filosofie bestaat niet uit een aaneenrijging van concepten, maar uit het beschrijven van de omgang van het bewustzijn met de wereld, zijn betrokkenheid in het lichaam en zijn co-existentie met anderen [...].' (Merleau-Ponty $1966: 105)^{46}$ Dat heeft bepaalde consequenties voor de waarde van Ons mankeert niets. Als we de roman beschouwen als een uitdrukking van Ottens geloof in het lot, dan zijn we bijna gedwongen de literaire waarde van het boek in twijfel te trekken. Vanuit het standpunt van MerleauPonty moeten we begrippen als 'het lot' of 'noodlot' zien als begrippen die over de werkelijkheid gelegd worden, en die daardoor niet in de literatuur voorkomen mogen. 'Een geslaagde roman,' schrijft MerleauPonty, "bestaat niet uit een optelsom van ideeën of stellingen, maar bestaat op de manier van een zintuiglijk ding, van een ding in beweging waarbij het erom gaat dat men dit waarneemt in zijn temporale ontwik- 
keling. Hiervan volgt men het ritme dat in onze ontwrikkeling niet een geheel van ideeën achterlaat, maar veeleer het embleem en het monogram van deze ideeën." (Merleau-Ponty 2002:60-61) 47 $^{7}$

Dit alles geldt volgens Merleau-Ponty in eerste instantie meer voor de moderne roman dan voor de klassieke, omdat de laatste vaak zoveel helderder, afgerond en daardoor voorspelbaarder lijkt dan de eerste: 'Bij de modernen zijn het niet alleen de werken die onvoltooid zijn, maar ook de wereld zelf die hierin tot uitdrukking wordt gebracht is als een werk zonder conclusie en waarvan men ook niet weet of het ooit een conclusie zal hebben.' (Ibid.:65) 4 $^{8}$ Moderne romans brengen daarom volgens MerleauPonty de werkelijkheid beter tot uitdrukking dan een klassiek drama als Andromache van Euripides, waarvan de afloop voor iedere lezer duidelijk is: "Het is immers zo klaar als een klontje dat als Pyrrhus Andromache zou laten vallen en voor Hermione zou kiezen, zij dan geheel en al aan zijn voeten zou liggen. Maar wie kan daarentegen zeggen of de verteller in het werk van Proust werkelijk van Albertine houdt?'(Ibid.:64-65) ${ }^{49}$

Als we Ons mankeert niets beschouwen als de uitdrukking van Ottens opvattingen over euthanasie en hulp bij zelfmoord, dan is de roman niets anders dan een samenvatting van ideeën. Die ideeën lijken haaks te staan op het belang dat Otten aan de weergave van de complexe werkelijkheid hecht. Lezen we het boek enkel en alleen als een verhaal dat over niets anders gaat dan de dagelijkse praktijk van een bepaalde arts, dan vertelt het ons niets over algemene, menselijke zaken als de omgang met de doodswens van een ander. Maar beschouwen we de roman als een verhaal over de ambiguiteit van een concreet, menselijk probleem, dan toont hij ons, net als de schilderijen van Cézanne of de romans van Stendhal, de werkelijkheid zoals die is voordat we erover nadenken: onvoltooid, complex en in voortdurende beweging; een twee-eenheid van object en subject, van algemeenheid en particulariteit. De kennis die een roman ons biedt, is, net als de kennis die de nieuwe filosofie oplevert, nooit eenduidig. Het weten is nooit doorzichtig. "Het weten houdt altijd een zeker ambigu karakter en blijft daarom open in alle richtingen,' schrijven Rens Vlasblom en Douwe Tiemersma in de inleiding van hun vertaling van Phénoménologie de la perception.

Het is niet eenvoudig de ambiguiteit wan het lichaamsubject en de prereflectieve ervaring te denken. De ambigue eenheid wan het lichaamsubject enerzijds en die van de werkelijkheid en het lichaamsubject anderzijds laten zich makkelijker begrijpen als we naar de ontwikkeling van het kind kijken. Die ontwikkeling, zegt Merleau-Ponty, vindt plaats binnen een sensomotorisch proces. Als het kind de wereld om zich heen verkennen gaat, krijgt het door middel van de tastzin een begrip van de dingen en van zichzelf. Door de verschillende objecten te voelen, leert 
het kind niet alleen de vorm van de dingen kennen, maar leert het ook hoe het ene ding zich onderscheidt van het ander. Op dezelfde manier leert het ook de grenzen van zijn eigen lichaam kennen. In de aanraking komen lichaam en object tot elkaar, maar tegelijkertijd verwijderen ze zich van elkaar. In de aanraking, in het contact worden meteen ook de verschillen tussen lichaam en objecten duidelijk. De identiteit van alle objecten, maar ook die van de mens zelf, ontstaan in een beweging van verwijzing en ontkenning. Anders gezegd, identiteit is nooit statisch, maar komt tot stand in de verhouding van het lichaamsubject tot de concrete wereld, waarvan het deel uitmaakt.

De structuur van de taall is niet anders dan die van de ervaring. Merleau-Ponty liet zich inspireren door de Zwitserse linguist Ferdinand de Saussure, die stelt dat een woord uit de twee-eenheid klank en betekenis bestaat. Een woord verwijst volgens De Saussure nooit alleen naar zichzelf. Bovendien betoogt hij dat de betekenis van woorden niet verwijst naar achterliggende ideeën. De betekenis van een woord wordt niet tijdens het spreken aan de woorden toegevoegd, maar komt tot stand in relatie met andere woorden. 'Wat we van De Saussure hebben geleerd, schrijft Merleau-Ponty, "is dat tekens op zich geen enkele betekenis hebben, en dat ze elk niet zozeer een betekenis uitdragen, als het verschil in betekenis tussen zichzelf en andere tekens markeren.' (Merleau-Ponty 1960a:49) $)^{\text {so }}$

De taal is volgens Merleau-Ponty van een zelfde ambiguïteit doortrokken als de verhouding tussen de objecten en het lichaamsubject. Dat geld took voor de verhouding tussen het lichaamsubject en de taal. Betekenis ontstaat van binnen uit, binnen de structuur van verwijzing en ontkenning. Net zomin als ik om te kunnen handelen mijn denken tussen mijn bewustzijn en de werkelijkheid schuif, hoeft een kind een woordenboek uit zijn hoofd te leren om te kunnen spreken. Waarneming en taal zijn twee kanten van onze waarneming; beide ontstaan op het snijpunt van de ontmoeting tussen het lichaamsubject en de concrete werkelijkheid.

Ervaring ontstaat dus binnen een structuur van 'circulaire dialectiek': betekenis wordt gegenereerd in een voortdurend proces van wederkerigheid en ontkenning. Dat geldt voor de structuur van de taal, maar ook voor die van de waarneming en de ervaring. Wij bepalen de taal, maar worden ook bepaald door de taal. Wij groeien op binnen de taal. De Saussure laat zien dat de taal en het lichaamsubject niet zonder elkaar bestaan. De taal is geen fenomeen op zich, maar bestaat alleen in sprekende subjecten, terwijl we de taal ook weer niet als een karaktereigenschap of een functie van het subject begrijpen mogen. Mensen zijn altijd tegelijk subject en object van taal. Bovendien brengt de taal de afhankelijkheid 
van mensen onderling tot uitdrukking. Omdat we in een 'sprekende gemeenschap leven," schrijft Merleau-Ponty, "is het sprekende subject niet de eigenaar van zijn taal. Taal is niets anders dan de wil om te begrijpen en begrepen te worden. [...] Daarom is taal ten opzichte van alle sprekende mensen geen transcendente realiteit; taal is evenmin een illusie die door het individu gevormd wordt. Taal is een manifestatie van intersubjectiviteit.' (Merleau-Ponty 1964c:257, cursivering in origineel) ${ }^{51}$

Betekenis is daarom altijd tot op zekere hoogte relatief. Omdat ze altijd binnen een bepaalde situatie ontstaat, kan ze nooit algemeen worden. Dat betekent echter niet dat ze onbelangrijk is. Hetzelfde geldt voor abstracte ideeën, of voor regels en wetten. Ook die zijn binnen een bepaalde situatie ontstaan, en hebben binnen die situatie betekenis. Problematisch wordt het gebruik van regels en modellen pas als we vergeten hoe ze ontstaan zijn, waarom we ze ontworpen hebben, dat ze geen transcendente waarheid vertegenwoordigen en wanneer we ze opdringen aan de werkelijkheid. Of wanneer we vergeten dat waarneming en bewustzijn geen lege begrippen zijn die door de wereld gevuld worden, of die de wereld een bepaalde worm geven, maar altijd waarneming en bewustzijn van iets zijn. Waarneming en bewustzijn ontwikkelen zich immers vanaf de vroegste ontmoeting met de wereld..$^{2}$

Zodra we waarneming en bewustzijn los proberen te maken van hun inhoud, en we de theorie belangrijker achten dan de concrete ervaring en de wereld waarin we met elkaar leven, heeft de theorie geen enkele waarde. De theorie komt voort uit de ervaring, nooit andersom. Wetenschappelijke analyses zijn niet primaire, maar secundaire ervaringen:

Alles wat ik van de wereld weet, zelfs via wetenschappelijke weg, weet ik op grond van een gezichtspunt dat het mijne is, op grond van een ervaring van de wereld, zonder welke de symbolen van de wetenschap nietszeggend zouden zijn. Het hele universum van de wetenschap is geconstrueerd op de geleefde wereld en als we de wetenschap zelf streng willen doordenken en er nauwkeurig de zin en draagwijdte van willen bepalen, moeten we eerst die ervaring van de wereld opnieuw tot leven wekken warvan de wetenschap slechts de secundaire uitdrulkking is.

(Merleau-Ponty 1945:II-III) ${ }^{53}$

In de nieuwe filosofie gaat het niet langer om antwoorden op de vragen 'waarom besta ik' en 'hoe kan ik iets weten'. De nieuwe filosofie biedt geen zekerheden meer. Ze is een methode, die net als de literatuur en de beeldende kunst op zoek gaat naar de ervaring die voorafgat aan alle verklaringen. 
De nieuwe filosofie kan ons echter well helpen een antwoord te vinden op de vraag wat we moeten doen, als we tenminste niet verwachten dat ze ons kant en klare oplossingen aanreikt. Voor zover we bij MerleauPonty van ethiek kunnen spreken - Antje Kapust (1999) spreekt van 'ethische dimensies' in plaats van ethiek - is die geworteld in het besef dat de basis van onze ideeenn zich bevindt in de ambiguitteit en de intersubjectiviteit van de concrete werkelijkheid. De nieuwe filosofie kan ons van de analyse en de wetenschappelijke verklaring terugvoeren naar de concrete werkelijkheid waaruit die ontstaan zijn. Zo laat ze zien hoe reflectie en wetenschap tot stand komen, en ook wat de waarde is van wetenschappelijke kennis. Komen wetenschappelijke uitspraken niet tot stand vanuit de concrete ervaring, maar worden die toegevoegd aan de werkelijkheid, dan zijn die uitspraken van generlei waarde. Hetzelfde geldt voor ons oordelen en ons handelen. Als we oordelen en handelen vanuit een zuiver abstract idee, doen we hetzelfde als de traditionele fillosofie: we maken dan, zonder rekening te houden met de structuur van de concrete werkelijkheid, de werkelijkheid ondergeschikt aan een stramien van lege begrippen. Merleau-Ponty veroordeelt bijvoorbeeld in Les aventures de la dialectique het absolutisme van het vroegere sovjetsysteem, en legt in een interview, opgenomen in de bundel Signes, uit waarom hij het kolonialisme veroordeelt. Maar in dat interview vertelt hij ook dat hij het onverstandig acht louter en alleen vanuit de gedachte dat het kolonialisme passé is, alle gekolonialiseerde landen onmiddellijk te dekolonialiseren.

De filosofie van Merleau-Ponty geeft geen direct antwoord op de vraag wat je moet doen als je weet dat iemand sterven wil. Maar ze kan artsen wel helpen bij het bepalen wat ze doen moeten als zij van een van hun patiënten te horen krijgen dat die sterven wil, zonder te vervallen in hoogmoed, zonder toevlucht te nemen tot abstracties en op een wijze die alle betrokkenen in hun waarde laat. In de volgende paragrafen wordt daarom onderzocht hoe artsen met de zorgvuldigheidseisen om kunnen gaan zonder die eisen tot absolute waarheid te verheffen en zonder de prereflectieve ervaringen te veronachtzamen. Omdat Merleau-Ponty voor het bepalen van een houding ten opzichte van van vragen betreffende ons oordelen en handelen de literatuur even belangrijk vindt als de filosofie, richt ik me daarbij niet alleen tot Merleau-Ponty's geschriften, maar ook, opnieuw, tot Ons mankeert niets.

\section{slotsom}

Volgens Merleau-Ponty maken we voortdurend de vergissing de abstracte analyse belangrijker te vinden dan de concrete ervaring. Deze vergissing wordt gevoed door de traditionele filosofie en wetenschap, die de 
analyse als echter beschouwen dan de ervaring waaruit zij voortkomt. De primordiale ervaring wordt gekenmerkt door de twee-eenheid van de wereld en het lichaamsubject, waarbij de betekenis van de wereld door het lichaamsubject, dat altijd zowel waarnemer als waargenomene is, tot uitdrukking komt. Het is de taak van de filosofie om net als de schrijver en de schilder de oorspronkelijke eenheid van mens en wereld tot uitdrukking te brengen. Op die manier kan de filosofie bijdragen aan het ontmaskeren van ideeën als "onechte" ideeën, dat wil zeggen, als ideeën die niet voortkomen uit de werkelijke ervaring, maar daaroverheen gelegd worden.

\section{Motivatie komt na de beslissing}

Euthanasie, zegt de wet, mag alleen uitgevoerd worden wanneer de betrokken patiënt daartoe vrijwillig en weloverwogen een verzoek heeft gedaan. Otten hekelt de gedachte van wilsvrijheid die schuilgaat achter deze bepaling. Niet wijzelf, stelt hij, maar het lot beschikt over ons levenseinde. Hij bekritiseert bovendien de aanname dat we te allen tijde op een zuiver rationele manier - het woord 'weloverwogen' impliceert een zuiver rationele overweging - kunnen nadenken en beslissen over vragen betreffende leven en dood. Ten derde bekritiseert hij de impliciete aanname dat beslissingen over leven en dood strikt individuele aangelegenheden zijn. De mens, stelt hij, is niet vrij: ons denken en handelen worden bepaald door de situatie waarin wij ons bevinden, door de mensen om ons heen en door het lot.

In Ons mankeert niets lijkt Justus, hoe je de roman ook leest, het voorbeeld te zijn van een arts die voortdurend probeert zo rationeel mogelijk te handelen en die zich liever laat leiden door zuiver abstracte regels dan door de concrete werkelijkheid. Dat heeft onaangename gevolgen voor zijn patiënten die ongeneeslijk ziek verklaard zijn. Die denken dat ze zelf bestemmen wanneer ze sterven zullen, maar in werkelijkheid bepaalt Justus het tijdstip van hun dood. Uiteindelijk blijkt dat de manier waarop Justus met zijn patiënten omgat veel meer gestuurd wordt door emoties dan door een verlangen naar rationaliteit. Dokter Daan daarentegen handelt niet uit abstracte principes, maar laat zich leiden door de levens en de verhalen van zijn patiënten. Dat wil niet zeggen dat hij altijd louter en alleen vanuit emoties handelt. Zodra hij dat wel doet, brengt hij zichzelf in problemen. Nadat hij zijn vrouw bij haar zelfdoding geholpen heeft, wil hij ook zelf niet verder leven. Moeten we daarom uit Ons mankeert niets afleiden dat Otten gelijk heeft als hij stelt dat vrijwilligheid en we]overwogenheid begrippen zijn die onmogelijk met de dood geassocieerd kunnen worden? 
Vanuit het perspectief van Merleau-Ponty kunnen we met die stelling tot op zekere hoogte instemmen. Handelen en reflectie zijn gegrondvest in de wereld waarvan wij deel uitmaken - in onze omgeving, in de taal en in onze verhouding tot anderen. Hoe wrij zijn zieken die zich overmeesterd voelen door pijn en lichamelijke ongemakken? En hoe overwogen kunnen zij oordelen als zij zich door pijn of slechte vooruitzichten voor genezing gedwongen voelen een besluit te nemen? Zelfs als we niet ziek zijn, vinden we het moeilijk ons te onttrekken aan de meningen en oordelen van anderen. Hoe moeilijk moet het voor een zieke niet zijn zich niet te laten beïnvloeden door de opinies en oordelen van anderen. Hoe kunnen we daarom ooit spreken van een geheel vrijwillig en weloverwogen verzoek?

Van een absoluut, geheel onafhankelijke vrije keuze, zou ook MerleauPonty in dit geval warschijnlijk zeggen, kan geen sprake zijn, laat staan van een zuiver rationele beslissing. Maar dat betekent niet dat we, zoals Otten stelt, nooit vrijwillig en weloverwogen een beslissing kunnen nemen. De oplossing van het probleem ligt in de interpretatie van de begrippen. Als we 'vrijwilligheid' en 'weloverwogenheid' opvatten als eigenschappen of mogelijkheden die bestaan buiten onze dagelijkse werkelijkheid, of beter, buiten onze gesitueerdheid en buiten onszelf om, dan heeft Otten gelijk. In dat geval zoeken we naar rationele oplossingen die met de werkelijkheid niets te maken hebben en daar als het ware overheen gelegd worden. 'Vrijheid' is dan slechts een abstractie. Maar in werkelijkheid, zegt Merleau-Ponty, worden we geleid door 'geheime', onberedeneerde beslissingen. Die beslissingen maken de motieven duidelijk, niet andersom. Motieven leiden niet tot beslissingen, maar komen uit beslissingen voort. "Wat ons [...] misleidt,' zegt Merleau-Ponty, 'is dat wij de vrijheid dikwijls in een opzettelijke afweging zoeken die keer op keer de motieven naloopt en zich naar het meest krachtige of het meest overtuigende lijkt te schikken. In werkelijkheid volgt de afweging op de beslissing; het is mijn geheime beslissing die de motieven laat verschijnen [...].' (Merleau-Ponty 1945:497-498) ${ }^{\text {s }}$

Een verklaring van ons gedrag is slechts mogelijk omdat het gedrag aan de verklaring voorafgaat. Analyses van onze verhouding tot de dingen om ons heen vinden plats op basis van de primordiale twee-eenheid van mens en wereld. Vaak weten we pas wat we willen als we ons bedenken. 'Daarom ervaar ik,' stelt Merleau-Ponty vast, 'nadat ik van een plan heb afgezien, zo vaak een bevrijding: "Al met al was ik er niet zozeer aan gehecht", alle overwegingen waren er slechts voor de vorm, de afweging was een parodie, mijn afwijkende beslissing was allang genomen.' (Ibid.:498) ss $^{5}$

Voordat we een verklaring geven van ons gedrag of onze beslissingen, 
stond allang vast wat we wilden doen. We zien dat aan de wijze waarop Justus gedurende die twee dagen in maart steeds zijn manier van handelen probeert te rechtvaardigen. De eis dat we weloverwogen een beslissing over ons levenseinde nemen, zouden we daarom met Otten kunnen afdoen als een verwerpelijke, want irreële eis. Maar dat wil niet zeggen dat van overwogen beslissingen nooit sprake kan zijn. We mogen $z$ zegt Merleau-Ponty, de reflectie niet als belangrijker beschouwen dan de prereflectieve ervaring. Maar we hoeven haar ook niet af te wijzen. Reflectie ontstaat dankzij de prereflectieve vertrouwdheid met de wereld, en hoeft daarom niet per se een vertekening of een verarming van de werkelijke ervaring te betekenen. Ze kan evenzogoed een waardevolle aanvulling of verklaring zijn, vooral in het contact met anderen. Bovendien is het de vraag wat er bedoeld wordt met 'weloverwogen'. Een rationele verklaring kan onze beslissing verduidelijken en bespreekbaar maken, en haar daardoor de vorm van weloverwogenheid geven. Dat wil niet zeggen dat een verklaring een hoger waarheidsgehalte heeft dan de beslissing die aan haar voorafgaat. Maar het betekent evenmin dat we ons bij al onze beslissingen altijd slechts door emoties, duistere verlangens en tegenstrijdige gevoelens laten leiden, zoals Otten lijkt te denken, of dat we altijd gedreven worden door de wensen van anderen. Gesprekken met anderen kunnen helpen onze beslissingen tot motieven om te vormen. Dat is wat dokter Daan doet: hij geeft zijn patiënten geen abstracte antwoorden op hun vragen, maar hij laat ze hun eigen antwoorden formuleren. Op die manier helpt hij Steffie een manier te vinden om erachter te komen of ze aantreklkelijk is voor jongens. Hij zet haar onuitgesproken verlangen naar aanraking om in een advies, waardoor het voor haar acceptabel wordt een verhouding aan te gaan met een jongen. Ook Justus helpt, weliswaar ongewild, mevrouw sleutel in het reine te komen met haar verlangen naar de dood. Ook hij voorziet zijn patiënten van motieven voor een beslissing die ze allang genomen hadden. Als hij de bakkersvrouw vertelt dat ze niet bang hoeft te zijn dat hij haar niet bij het sterven helpen zal, komt ze tot rust: de dokter heeft haar verlangen naar de dood geformuleerd en gesanctioneerd.

De prereflectieve ervaring is geen ondoorgrondelijke, prerationele of pretalige, on bewuste aangelegenheid. Ze bestaat niet uit onbegrijpelijke emoties of lege indrukken. Dat zou het kunnen zijn als de mens uit twee aparte entiteiten bestaan zou, uit een lichaam en een geest. Voordat we onszelf echter opdelen in een lichaam en een geest, zijn we een lichaamsubject, een ambigue eenheid van lichaam en bewustzijn. Onze waarneming is gebed in de taal, en de taal ontstaat in de waarneming. De taal wordt niet toegevoegd aan de waarneming, maar beide ontstaan in en door elkaar. Taal en waarneming zijn net als het lichaam en het bewustzijn een twee-eenheid. 
Het begrip 'weloverwogenheid' zou vanuit dit perspectief in eerste instantie te maken kunnen hebben met de prereflectieve motivatie; met een nog onberedeneerde overtuiging of levenshouding. Een rationele verklaring geeft in het gunstigste geval een communicabele vorm aan het motief en voegt daaraan iets toe. In het ongunstigste geval staat de verklaring los van de prereflectieve ervaring en probeert hij die te manipuleren. Ottens kritiek richt zich op het laatste.

Maar hoe weten we wanneer een motivatie voortkomt uit een beslissing, of, andersom, de motivatie een beslissing beïnloedt? Romans, zegt Merleau-Ponty, kunnen bij de herkenning van de dynamiek van motieven een rol spelen. Niet, zoals Otten stelt, om te laten zien dat wij gestuurd worden door het lot en dat er daarom van zelfbeschikking geen sprake kan zijn. Ook niet om duidelijk te maken dat de reflectie losstaat van de prereflectieve ervaring. Romans kunnen ons helpen een onderscheid te maken tussen motieven die uit een beslissing voortkomen en motieven die daaraan worden toegevoegd. Toegevoegd is bijvoorbeeld Justus' rationalisering van de macht die hij over zijn patiënten probeert uit te oefenen. Hij beroept zich immers voortdurend op abstracte regels op regels die niet uit de werkelijkheid voortkomen, maar daarover heen gelegd worden. Hij verzint argumenten om zijn omgang met zijn patiënten en zijn verhouding met zijn maîtresse te verdedigen, en hij weet dat hij die verzint. Mevrouw Sleutels besluit om de arts om euthanasie te vragen, lijkt daarentegen voort te komen uit een werkelijk verlangen naar de dood. Dat geld took voor dokter Daans beslissing om te sterven.

Wat voor het begrip van weloverwogenheid geldt, geldt ook voor het idee van een buitenmenselijk lot of een buitenmenselijke eenheid, die ons doen en laten bepaalt. In het essay 'Le roman et la métaphysique', waarin Merleau-Ponty op de roman L'invitee van Simone de Beauvoir ingaat, richt hij zich onder andere op de vraag naar het bestaan van een eeuwig geldende en bindende moraal. Een dergelijk concept, meent hij, is ontstaan vanuit de gedachte dat de betekenis van de wereld buiten de wereld zelf ligt. Maar omdat de verbondenheid van wereld en lichaamsubject ten grondslag ligt aan alle gedachten over de wereld, kan er geen sprake zijn van een alles bepalend, van hogerhand opgelegd concept. Alles wat "metafysisch is in de mens," schrijft hii, "kan niet aan iets buiten het empirisch bestaan worden toegeschreven - aan God of aan Bewustzijn. De mens is metafysisch in zijn directe bestaan, in liefde, in haat, in zijn individuele en collectieve geschiedenis, en de metafysica is niet langer een bezigheid voor een paar uur per maand, zoals Descartes zei; ze is aanwezig, zoals Pascal dacht, in de geringste bewegingen van het hart.' (Merleau-Ponty 1966:48) ${ }^{56}$ Het metafysische is volgens Merleau-Ponty de betekenis die ontstaat in het primordiale contact tussen lichaamsub- 
ject en de concrete werkelijkheid. Een moral die zich beroept op zogenaamde absolute waarheden komt niet voort uit de werkelijkheid, maar wordt daaraan toegevoegd.

Merleau-Ponty ontkent niet dat de mens morele verantwoordelijkheid heeft. Hij ontkent alleen de mogelijkheid te definiëren wat moraal is of moet zijn. Moraal wordt ons niet aangereikt. Wij moeten de moraliteit zelf ontdekken. Ook dat laat het voorbeeld van Justus zien. Wanneer Iustus zich op regels, handleidingen en voorschriften beroept, helpt hij zijn patiënten niet en kan hij ook niet de zelfdoding van dokter Daan verijdelen. Zijn vertrouwen in regels leidt integendeel tot een vervreemding van de werkelijkheid; zijn verlangen naar een vastomlijnde, opgelegde moraal doet hem in paniek vluchten wanneer hij beseft dat Daan zich heeft laten leiden door diens eigen moraal.

Maar hoe zit het nu met het begrip 'vrijwilligheid'? Van vrijwilligheid lijkt in beide lezingen nauwelijks sprake te zijn. Justus lijkt ten onder te gaan omdat hij geheel ten onrechte denkt dat hij zelf zijn handelen bepaalt. Ook zijn patiënten die om euthanasie vragen - meneer Galesloot en mevrouw Sleutel - lijken dit uit eigen vrije wil te doen, maar in werkelijkheid beslissen de artsen over het levenseinde van hun patiënten. Ons mankeert niets zou daarom als een weerlegging van het bestaan van de vrije wil gelezen kunnen worden.

Ook dat zouden we beschouwen kunnen als een raakpunt tussen Otten en Merleau-Ponty. Zowel Merleau-Ponty als Otten ontkent het bestaan van een zuiver vrije wil. Merleau-Ponty doet dat echter om andere redenen dan Otten. Otten verwerpt het idee van een vrije wil omdat hij meent dat de mens gestuurd wordt door het lot. Merleau-Ponty wijst het begrip 'vrije wil' af, omdat 'de wil' volgens hem net zo min als 'het bewustzijn' of 'het denken' als een instrument bestaat. We zijn bewustzijn, net zoals we een lichaam zijn en we als lichaamsbewustzijn in de wereld, in de ruimte en in de tijd leven. We schuiven ons denken niet tussen onszelf en de wereld, maar we maken als lichaamsubject deel uit: van de wereld. Ons handelen richt zich altijd op iets. Bewustzijn en handelen zijn geen losse instrumenten die we naar believen gebruiken: ze definiëren ons bestaan.

Hetzelfde geldt voor de taal. We gebruiken de taal niet als een middel tot een doel, maar we leven in de taal. Ons bestaan is gesitueerd: we leven in de taal, in de tijd, in de ruimte, met anderen met wie we voortdurend communiceren, met dingen waaraan we voortdurend betekenis ontlenen en geven. Die gesitueerdheid mag niet gedacht worden als een beperking. De taal geeft ons de mogelijkheid tot transcendentie, tot het geven van steeds nieuwe betekenissen. Wat dat betreft zijn we vrij én onvrij. De wereld is geen leegte waarop we naar believen betekenissen pro- 
jecteren. Toch kunnen we steeds uitstijgen boven het direct gegevene. Merleau-Ponty illustreert dit met een concreet woorbeeld: als wij de dingen aanraken, ontstaat in die aanraking dankzij de vorm van het object en dankzij het bewustzijn betekenis. Lichaamsubject en object geven en ontvangen tegelijkertijd een bepaalde zin. Als we met onze ene hand de andere aanraken, voelen we niet alleen hoe we aangeraakt worden, maar we voelen ook de aanraking zelf. In die zin is er altijd sprake van een dubbele betekenis. "Geboren worden is tegelijk vanuit de wereld en naar de wereld toe geboren worden," schrijft Merleau-Ponty. 'De wereld is reeds geconstitueerd, maar nooit volledig geconstitueerd.' (Merleau-Ponty $1945: 517)^{57}$ Daarin ligt onze vrijheid; in de ambiguiteit van ons bestaan, en vooral ook in de erkenning daarvan. Zodra we die ambiguiteit ontkennen, ontkennen we onze vrijheid:

De vrijheid kan mij alleen ontgaan als ik probeer mijn natuurlijke en sociale situatie te boven te komen door de aanvaarding ervan direct al te weigeren, in plaats van de natuurlijke en menselijke wereld. hierdoorheen te verenigen. Niets bepaalt mij van buitenaf, niet omdat niets mij zou aansporen, maar integendeel omdat ik meteen al buiten mijzelf en open naar de wereld sta. Wij zijn door en door waar, wij dragen alles wat nodig is om onszelf te overstijgen al met ons mee, alleen al vanwege het feit dat wij "naar de wereld zijn" en niet alleen, zoals de dingen, in de wereld. Wij hoeven niet te vrezen dat onze keuzen of onze handelingen onze vrijheid beperken, daar de keuze en de handeling ons hooguit van onze ankers bevrijden.

(Ibid.:520, cursivering in origineel) $)^{58}$

Daarom heeft het geen zin iemand het recht op vrijheid op te dringen, of ervan uit te gaan dat we in bepaalde situaties gebruik kunnen maken van een vrije wil die buiten het bestaan ligt. Wie denkt dat dat wel kan, maakt gebruik van een abstractie, en in die zin, zoals Merleau-Ponty het in La structure du comportement noemt, van een pseudo-oplossing. Pseudooplossingen geven het leven een 'geleende betekenis', ze zijn 'onecht'. Ze komen niet uit de werkelijkheid voort, maar worden over de werkelijkheid heen gelegd. Merleau-Ponty verwijst naar Stendhals roman Le rouge et le noir, waarin de studiegenoten van de hoofdpersoon onechte ideeën gebruiken om hun leven meer betekenis te geven dan het in werkelijkheid heeft:

[...]pseudo-oplossingen zijn herkenbaar aan het gegeven dat iemands wezen nooit samenvalt met wat hij zegt, wat hij denkt, of wat hij doet [...]. Onechte kunst, onechte heiligheid en onechte 
liefde, die zoals de seminariegenotern van Julien Sorel steeds "belangrijke daden" proberen te verrichten, geven het menselijk leven niet meer dan een geleende betekenis, ze hebben slechts een ideële transformatie tot gevolg, een vlucht in transcendentale ideeën.

(Merleau-Ponty 1942:194-195, cursivering in origineel) ${ }^{59}$

Met andere woorden: zodra we ons in bepaalde situaties beroepen op het recht van een vrije wil, nemen we onze toeviucht tot een idee dat niet voortkomt uit de concrete situatie. Als zieken zich beroepen op het recht op autonomie, beroepen zij zich op een abstracte regel. Daarmee laten zij zien dat zij niet vrij zijn. Want als zij zich werkelijk vrij voelen, hoeven zij zich niet op een idee te broepen; voelen zij zich onvrij, dan kan geen begrip hen bevrijden. Ook het omgekeerde is waar. Wij zijn niet in principe onvrij, en ons leven wordt niet van buitenaf bepaald. Vrijheid en onvrijheid liggen verankerd in ons bestaan. Daarom zijn we in staat in vrijheid een beslissing over ons leven te nemen. Als we vanuit onze gesitueerdheid besluiten dat we niet langer leven willen, dan is die beslissing vrij; laten we ons bij die beslissing leiden door een abstract idee, dan is van vrijheid geen sprake.

Zo bezien lijkt dokter Daan het schoolvoorbeeld te zijn van iemand die in authentieke vrijheid de beslissing neemt een einde aan zijn leven te maken. Vrijheid is voor hem geen "geleend begrip" - hij gebruikt het woord niet om zijn daad meer betekenis te geven dan die in werkelijkheid heeft. Nergens beroept hij zich op het recht op autonomie. Hij neemt zijn beslissing zonder zich te verliezen in allerlei theorieën over het recht op een wrije wil. Zijn beslissing word them door niemand opgedrongen. Integendeel: niemand kan hem van zijn voornemen afbrengen. Dat alles betekent niet dat er geen lotsbestemming bestaat. Wij gaan echter, anders dan Otten meent, niet gebukt onder onze lotsbestemming. Wij dragen haar in ons. Ook dat demonstreert het voorbeeld van dokter Daan. Hij wordt niet door het lot gedwongen een eind aan zijn leven te maken. Hij wilde gewoon dood, vertelt Steffie aan 》ustus. Hij wil dood omdat hij zich bevindt in een situatie waarin hij de lust heeft verloren om verder te leven. Zijn beslissing is niet hoogdravend en niet laag-bijde-gronds; hij motiveert zijn voornemen niet met abstracte principes, maar hij wil evenmin uit boosheid of koppigheid of vanwege jaloezie een einde maken aan zijn leven. Het heeft daarom geen zin hem tot andere gedachten proberen te brengen; geen wet of regel zal hem doen afzien van $z i j n$ voornemen.

In dit geval is dokter Daan een patiënt, en niet een arts die geconfronteerd wordt met een euthanasieverzoek. Maar ook als arts maakt hij duidelijk hoe je erachter kunt komen in hoeverre een euthanasieverzoek 
werkelijk gewild is en niet tot stand is gekomen door oneigenlijke motieven en redeneringen. In zijn gesprekken met zijn patiënten richt hij zich op hun voorgeschiedenis, hun angsten en wensen. Hij weet hen letterlijk en figuurlijk aan te raken, waardoor hij hen in staat stelt hun verlangens te verwoorden. Hij prikt door clichés en holle frases heen. Hij richt zich op de concrete ervaring.

We mogen onze vrijheid niet in 'onoprechte discussies' zoeken, meent Merleau-Ponty. 'De echte keuze,' schrijft hij, 'is een keuze die ons gehele karakter en onze wijze van "naar de wereld zijn" aangaat.' (Merleau-Ponty $1945: 501)^{6 \circ}$ Zo'n keuze is niet tastbaar, ze is even onzichtbaar als de waarneming of het bewustzijn. In die zin is ook onze vrijheid niet zichtbaar te maken. Wij dragen vrijheid uit. Maar dat betekent niet dat we niet onvrij kunnen zijn of onvrij gemaakt kunnen worden. Artsen zowel als patiënten kunnen het begrip 'vrijheid' of 'autonomie' als een pseudo-oplossing gebruiken. Artsen kunnen een patiënt een oplossing opdringen, die niets te maken heeft met de vrijheid van de patiënt. Justus lijkt dikwijls zo'n arts te zijn. Dokter Daan daarentegen lijkt zijn patiënten vooral te helpen omdat en hoe zij dat willen. Waar het voorbeeld van dokter Daan laat zien wat echte vrijheid is, toont dat van Justus aan wanneer vrijheid een 'geleende betekenis' krijgt.

\section{Slotsom}

Absolute vrijheild en weloverwogenheid per se bestaan niet volgens Merleau-Ponty. Wij zijn als lichaamsubjecten ingebed in de wereld, en onze beslissingen staan nooit los van de situatie waarin wij ons bevinden. Reflectie ontstaat, voor zover we haar als waarachtige reflectie beschouwen mogen, vanuit de prereflectieve ervaring. Dat wil echter niet zeggen dat we nooit vrijwillig en op een weloverwogen manier keuzes kunnen maken. Onze vrijheid is ingebed in ons bestaan. Als lichaamsubject zijn we altijd zowel onvrij als vrij: we maken deel uit van de wereld, maar ontstijgen die tegelijkertijd. Belangrijk is dat we beseffen hoe onze overwegingen tot stand komen: onze motieven formuleren we altijd nadat we een beslissing hebben genomen. In de reflectie en in gesprekken met anderen kunnen we die beslissingen uitdiepen en tot uitdrukking brengen in rationele motieven, waardoor we in staat zijn onze beslissingen met anderen te bespreken. Dit in aanmerking genomen lijkt dokter Daan met zijn aandacht voor de tweede klacht de ideale arts te zijn. Justus daarentegen lijkt zich te vaak te beroepen op 'onwaarachtige motieven'. 
In de zorgvuldigheidseisen staat vermeld dat ex in geval van euthanasie altijd sprake moet zijn van uitzichtloos en ondraaglijk lijden. Volgens Otten is het onmogelijk een objectieve definitie te geven van uitzichtloos en ondraaglijk lijden. Lijden, zegt hij, is altijd subjectief en valt daarom niet te meten en te classificeren. Datblijkt uit wat Justus in navolging van dokter Daan 'de tweede klacht' noemt. De eerste klacht is vaak meetbaar en behandelbaar. Maar onder de eerste klacht gaat een klacht schuil die niet meetbaar is. Dat is bijna altijd de belangrijkste klacht. Over welk lijden, kun je je afvragen, gaat het in de wet op euthanasie? En hoe kun je vaststellen of het lijden van een patiënt werkelijk uitzichtloos en ondraaglijk is?

In zijn essays verwoordt Otten een tweede bezwaar tegen de classificatie van lijden. Volgens hem heeft het menselijk lijden een bepaalde waarde, of een bepaalde zin. Als we dat niet erkennen, lopen we het gevaar dat lijden een nieuw taboe wordt en dat van iedereen die lijdt automatisch verwacht wordt dat hij of zij om euthanasie vraagt.

Het idee dat we lijden kunnen classificeren, lijkt inderdaad haaks te staan op onze dagelijkse ervaring. Lijden is een persoonlijke ervaring: de mate waarin we lijden hangt af van de situatie waarin we ons bevinden, onze voorgeschiedenis en ons karakter. Een classificatie is een abstractie van onze ervaring en geeft daarom slechts ten dele weer hoe wij ons voelen. Justus maakt zichzelf wijs dat dokter Daan niet lijdt, omdat hij officieel niets mankeert. Die gedachte gebruikt hij als excuus. Hij weet best dat dokter Daan lijdt en dat hij voor dat lijden geen officiële kwalificatie bestaat.

Volgens Merleau-Ponty veronderstelt de mogelijkheid van een zuivere abstractie, en dus ook een classificatie of een kwalificatie, een causale verhouding tussen een autonoom bewustzijn enerzijds en een onbewust lichaam anderzijds: binnen die verhouding verklaart en bepaalt het bewustzijn wat het lichaam voelt. Maar dat is niet de realiteit. Vóór we ons bewust zijn dat we lijden, zegt Merleau-Ponty, bevinden we ons in een toestand van lijden die met kwalificaties nog niets te maken heeft: '[O]p het moment waarop ik mij tot mijzelf wend om mijzelf te beschrijven, heb ik het besef [...] van een algeheel ontwerp warin nog geen sprake van "bewustzijnstoestanden" is, laat staan van enigerlei kwalificaties." (Merleau-Ponty 1945:496) ${ }^{61}$

Kwalificaties geven we, net als motieven, altijd achteraf. Vaak gebeurt dat onder invloed van uitspraken van anderen. Onze omgeving noemt ons een patiënt, terwijl we ons zo nog helemaal niet beschouwen, net zomin als we ons identificeren met de kwalificaties van ons beroep of 
ons karakter. "Voor mijzelf ben ik niet "jaloers", noch "nieuwsgierig", noch "gebocheld", noch "ambtenaar", schrijft Merleau-Ponty. (Ibid.)" Hetzelfde geldt voor de kwalificatie "uitzichtloos en ondraaglijk lijden". Vaak verbazen we ons erover dat zieken of invaliden in staat zijn hun last te dragen, zegt Merleau-Ponty. Dat heeft daarmee te maken dat zij "voor zichzelf niet invalide of stervende zijn". (Ibid.) ${ }^{6} 3$ Zodra ze zichzelf zo noemen, nemen ze afstand van zichzelf. Dan zien ze zichzelf door de ogen van een ander, en gaan ze voorbij aan wat ze zelf voelen. Ze noemen zich oud, ziek of invalide omdat hun omgeving hen als oud, ziek of invalide bestempelt. Daarmee handelen ze in mindere of meerdere mate te kwader trouw. We proberen onze toestand te objectiveren, maar als we dat doen geven we niet onze werkelijke gevoelens weer:

Tot aan het moment van coma wordt de stervende nog door een bewustzijn bewoond, is hij alles wat hij ziet en behoudt hij deze mogelijkheid tot ontsnapping. Het bewustzijn kan zich nooit tot een ziekenbewustzijn of een invalidenbewustzijn objectiveren; en zelfs als de grijsaard zich beklaagt over zijn ouderdom of de invalide over zijn gebrek, kunnen zij dat alleen maar doen voorzover zij zich met anderen vergelijken of voorzover zij zich door de ogen van anderen zien, dat wil zeggen, voorzover zij ten opzichte van zichzelf een statistisch en objectief stand punt innemen; en deze klachten zijn nooit geheel en al te goeder trouw: terug in het diepst van zijn bewustzijn, woelt iedereen zich boven zijn kwalificaties verheven en doet er meteen afstand van.

(Ibid.) $)^{64}$

Wanneer we zeggen dat we om euthanasie vragen als we niet meer kunnen lopen of aan geheugenstoornissen gaan lijden, zien we het lijden als iets dat toegevoegd wordt aan ons leven. Dan beschouwen we het lijden zoals de traditionele filosofie zich het bewustzijn voorstelt: als iets dat zich tussen het ik en de wereld bevindt. Maar "wij maken ons nooit los van ons leven," zegt Merleau-Ponty. "We zien onze ideeën of onze vrijheid nooit in het gezicht." (Merleau-Ponty 1945:44) ${ }^{65}$ Mensen die lang voordat zij ziek zijn bepalen dat zij om euthanasie zullen vragen als zij niet langer gezond zijn, beschouwen ziekte en dood als abstracte ideeën die zij over de werkelijkheid kunnen leggen; voor de werkelijkheid zelf, die onvoorspelbaar en ambigu is en die zich niet in modellen laat vastleggen, hebben zij geen oog.

Dat alles wil echter niet zeggen dat we ons niet werkelijk doodziek kunnen voelen, of dat we niet werkelijk naar de dood kunnen verlangen. Er is een goede reden waarom we onszelf in dergelijke situaties een zieke 
of een invalide noemen. Om met anderen over onze toestand praten te kunnen, moeten we er nu eenmaal kwalificaties gebruiken. Kwalificaties zijn hulpmiddelen die we nodig hebben om iemand anders duidelijk te maken hoe we ons voelen. Daarom voeren zieken die om euthanasie vragen vaak argumenten aan die onecht lijken, zoals de angst voor overlast voor hun omgeving, of het verlangen naar een waardige dood. En daarom ook moeten we gebruik maken van begrippen als 'ondraaglijk" en 'uitzichtloos'. We moeten dergelijke argumenten en begrippen niet belangrijker, maar ook niet onbelangrijker maken dan ze zijn. Onze werkelijke ervaring is altijd het fundament van de abstractie. Daarom is de tweede klacht, die vaak gebrekkiger verwoord wordt dan de eerste klacht, meestal echter dan de eerste. De eerste klacht valt vaak binnen het medische of algemene jargon, is dikwijls algemeen geaccepteerd, meetbaar en daarom makkelijker te bespreken. Maar de tweede klacht betreft dikwijls onze algehele situatie, ons bestaan zelf. Dat is precies waarnaar dokter Daan handelt, en wat \ustus veronachtzaamt. Dokter Daan begrijpt, zoals ook Justus ten slotte beseft, dat aan Justus' zorgen om een pukkeltje een andere, fundamentelere angst schulgaat. Hij laat Steffie ervaren wat ze werkelijk weten wil: dat ze aantrekkelijk is.

In hoeverre nu geeft het lijden zin aan ons bestaan, zoals Otten meent? Het antwoord op die vraag ligt in Merleau-Ponty's beschrijving van het lijden besloten. Als er al sprake is van een zin van het lijden, dan maakt die zin deel uit van de toestand waarin een zieke zich bevindt. Als zieken een bepaalde zin toevoegen aan hun bestaan, handelen zij, om met Merleau-Ponty te spreken, te kwader trouw. De zin van een bestaan is intrinsiek, en kan, net als onze ideeën, ons gezicht, onze karaktereigenschappen of onze manier van lopen niet door onszelf gekend worden. De zin van het bestaan laat zich nauwelijks definiëren, juist omdat die, net als de intentionaliteit van ons handelen en het bewustzijn, in het bestaan besloten ligt. Het bestaan en dus ook het lijden zijn doortrokken van zin. Zin is, net als lijden, geen objectiveerbaar begrip. Dat betekent dat de zin van het lijden ook tot uitdrukking kan komen in het verlangen naar de dood. Dat toont bijvoorbeeld het verhaal van mevrouw sleutel aan. Zodra zij het gevoel heeft dat Justus haar begrijpt, lijkt ze in haar situatie te berusten. Haar laatste dagen zijn, zo mag je aannemen, niet langer doortrokken van angst.

\section{Slotsom}

Wat voor onze beslissingen geldt, geldt ook voor de kwalificaties die we onszelf geven. Een zieke voelt zich pas een zieke als hij of zij de kwalificaties van een ander overgenomen heeft en zichzelf als een object beschouwt. Wie zichzelf een zieke noemt, voegt een betekenis toe aan zijn 
of haar bestaan die niet per se uit dat bestaan voortkomt. Daardoor is het onmogelijk een definitie van lijden te geven. Zodra we het lijden objectiveren, voegen we immers iets toe aan een situatie die nooit zo ervaren wordt als de objectivering aangeeft. Toch is de objectivering van het lijden geen probleem, zolang we beseffen dat we begrippen en uitdrukkingen gebruiken die niet noodzakelijkerwijs overeenkomen met wat de patiënt voelt. Bovendien is het dikwijls nodig dat we bepaalde kwalificaties gebruiken. Zonder die kwalificaties is het bijvoorbeeld bijna onmogelijk met een arts te praten. Zolang we de kwalificaties niet belangrijker vinden dan de werkelijkheid en geen begrippen gebruiken die op generlei wijze ontstaan zijn vanuit de werkelijkheid, handelen we niet te kwader trouw.

De zin van het lijden ten slotte ligt, voor zover we van zin spreken kunnen, besloten in het lijden zelf. Wie van buitenaf het lijden een bepaalde zin toekent, handelt uit onwaarachtige motieven.

\section{5} Zijn is zijn met de ander

Euthanasie is alleen dan legaal als de arts zijn of haar patiënt voldoende heeft ingelicht over diens of haar uitzichten. Bovendien moet de arts uitvoerig met een of meerdere collega's over het betreffende verzoek gesproken hebben éér hij of zij overgaat tot euthanasie. In zijn essays stelt Otten dat alleen al het op de hoogte zijn van de doodswens van een ander ons medeplichtig maakt aan moord. Artsen die met de patiënt en met hun collega's over euthanasie spreken, bevinden zich in een tragische situatie: zij doen iets dat begrijpelijk is, maar niet mag. Artsen die bij euthanasie betrokken zijn, al is het maar doordat ze geconsulteerd worden door een collega, moeten die last hun hele leven met zich meedragen.

Als we Ons mankeert niets volgens Ottens begrip van een tragedie lezen, leidt alleen al het vermoeden dat dokter Daan dood wil tot de ondergang van al zijn vrienden en vooral van Justus. De roman lijkt daarmee Ottens opvattingen over medeplichtigheid te bevestigen. Justus vermoedt dat dokter Daan zelfmoord plegen wil, en kan daardoor geen kant meer op. Of hij nu dokter Daans plannen negeert, hem daarvan probeert af te brengen, of hem helpt, hij maakt zich hoe dan ook medeplichtig. Het feit dat "we bestaan voor zover we met anderen samenhangen," zegt Otten, maakt ons schuldig, zodra we ook maar vermoeden dat iemand sterven wil. Volgens de historische lezing maakt Justus zich schuldig aan moord, omdat hij juist nauwelijks met zijn patiënten en zijn collega's praat. Hetzelfde geldt voor dokter Daan, die blijkbaar zonder een collega te consulteren zijn vrouw helpt zelfmoord te plegen. 
De vraag is in hoeverre een arts die door een patiënt om euthanasie gevraagd wordt en met patiënt en collega's over de situatie van de patiënt praat, zich schuldig maakt aan het beramen van moord. Kunnen artsen zich van die dood distantiëren, omdat zij gehandeld hebben naar de letter van de wet? Of maakt consultatie hen voor altijd schuldig? Bestaan we werkelijk voor zover we met anderen samenhangen?

Volgens Merleau-Ponty zijn onze levens altijd met die van anderen verbonden. Ons bestaan, zegt hij, is niet alleen intentioneel en ambigu, het is ook altijd intersubjectief. Volgens de traditionele filosofie en wetenschap is ons bewustzijn constitutief: het geeft betekenis aan de wereld en kan deze daardoor beheersen. Merleau-Ponty weert zich tegen die opvatting. Als ze waar zou zijn, is de ander niet veel meer dan een object. Als mijn bewustzijn de wereld constitueert, zegt Merleau-Ponty, kan ik geen ander bewustzijn denken, omdat in dat geval het andere bewustzijn immers mij constitueren zou. Dan zou ik niet degene kunnen zijn die de wereld constitueert. (Merleau-Ponty 1945:402 vv) In werkelijkheid wordt ons bewustzijn gevormd in relatie met de ander. Ook dat gebeurt in dezelfde beweging van verwijzing en negatie als die tussen object en lichaamsubject. Met andere woorden: ook intersubjectiviteit wordt gekleurd door intentie en ambiguiteit. Wij richten ons in ons spreken en handelen altijd op anderen. Taal krijgt pas betekenis binnen de communicatie, en herkenning en gemeenschappelijkheid maken het ons mogelijk met elkaar te communiceren. Maar dat betekent niet dat we volledig met de ander samenvallen. Subject en object moeten we niet denken als tegenstellingen, net zomin als we het ziende en het zichtbare en het voelende en het gevoelde als antithesen mogen beschouwen. Subject en object bevinden zich in een permanente reversibiliteit, een steeds aanwezige, niet waarneembare spiegeling waarin ze elkaar, vanuit elkaar, als subject en object laten bestaan, zonder zich van elkaar los te maken. Dat geldt ook voor ik en de ander: beiden zijn doortrokken van het algemene waarnemen. ' $[\mathrm{H}]$ et is niet $i k$ of hij die ziet,' schrijft Merleau-Ponty in zijn laatste, postuum verschenen werk Le visible et l'invisible, 'omdat een anonieme zichtbaarheid ons beiden bewoont, een algemeen zien." (Merleau-Ponty $1964: 187$, cursivering in origineel) ${ }^{66}$

De ervaring van de dood van een ander is een mooi voorbeeld van de mate waarin het leven door intersubjectiviteit gekleurd is. De dood van een ander doet ons weliswaar beseffen hoezeer we verbonden zijn met die ander, stelt Merleau-Ponty, maar diens dood kunnen we niet ervaren. De dood is immers geen algemene ervaring. De dood is het einde van een individueel leven. Daarom sterven we, hoeveel mensen zich ook om ons sterfbed bevinden, altijd alleen. Betekent dit dat we daarom, zoals André Malraux volgens Merleau-Ponty beweerde, ook altijd alleen leven? Mal- 
rauxs bewering, zegt Merleau-Ponty, berust op een verkeerde deductie. De dood laat niet zien hoe het leven is, maar omgekeerd: de dood laat, net als ziekte, zien wat het leven niet is. Het bewustzijn is niet ingekapseld in een lichaam. De essentie van het lichaamsbewustzijn is de gerichtheid op anderen:

Het is ontegenzeglijk waar dat ik alleen ben als ik lijd of sterf; maar is dit een normale verhouding of juist een ontbinding van het normale? Het lijkt dat in het aangezicht van de dood de ware essentie van het bewustzijn juist niet tot uitdrukking gebracht wordt. Malraux heeft ongelijk met zijn uitspraak dat'men alleen sterft en daarom alleen leeft'. In het leven is de essentie van het bewustzijn communicatie, waarbij je niet kunt zeggen wat van onszelf komt en wat van anderen. ${ }^{67}$

Ons bestaan ligt verankerd in intersubjectiviteit. De bewegingen van een baby, stelt Merleau-Ponty, zijn vanaf het begin gericht op die van anderen; baby's lachen in reactie op degene die naar hen lacht, nog zonder te weten waarom er gelachen wordt en zonder dat zij weten dat zij zelf lachen. Zij richten hun bewegingen naar die van een ander. Dat maakt duidelijk dat de bewegingen en handelingen van een ander intersubjectieve betekenis hebben. Zo schrijft Merleau-Ponty:

Een baby van vijftien maanden doet meteen zijn mond open, als ik spelenderwijs één van zijn vingers tussen mijn tanden neem en net doe alsof ik erop zal bijten. En toch heeft het kind nauwelijks zijn gezicht in een spiegel gezien en lijken zijn tanden niet op de mijne. Maar zijn eigen mond en zijn tanden, zoals het die van de binnenkant voelt, zijn voor hem meteen al bijtwerktuigen, en mijn kaken, zoals het die van de buitenkant ziet, zijn voor hem al onmiddellijk in staat tot eenzelfde intentie. Het "bijten" heeft voor het kind onmiddellijk een intersubjectieve betekenis. Het neemt zijn intenties in zijn lichaam waar, mijn lichaam met het zijne, en daardoor mijn intenties in zijn lichaam.

(Merleau-Ponty 1945:404) $^{68}$

Kinderen leren spreken in een identificatieproces. Ons hele wezen is van begin af aan gericht op anderen. Zo jong als het kind is, richt het zich op de dingen en mensen om hem heen. Zijn lichaam heeft geen instructies van buitenaf of van een sturend bewustzijn nodig om de eerste handelingen te verrichten. Het kind handelt, intentioneel, als reactie op de handelingen van anderen. Emoties leert het door de uitdrukkingen van anderen na te doen. 
Kinderen leren praten door zich te richten op de uitingen van de mensen om hen heen, en door het imiteren van hun geluiden. Dat nadoen hoeft het kind niet aangeleerd te worden. Het kind reageert uit zichzelf op andere mensen:

De beweging van het kind naar de taal is een voortdurend appel op anderen. Het kind herkent in de ander een ander zelf. Taal is het middel waarmee we wederkerigheid tot stand brengen. Hier gaat het zo te zeggen om een vitale transactie en niet alleen om een actie van het intellect. De representatieve functie is een aspect van de totale handeling waarmee we in communicatie met anderen treden.

(Merleau-Ponty $1964 \mathrm{c}: 235)^{69}$

De gerichtheid op de ander blijft ons leven lang bestaan. Ons spreken is altijd spreken met anderen; terwijl we luisteren, beginnen we al haast zelf te spreken. Spreken en luisteren, zegt Merleau-Ponty, zijn dubbelzijdige handelingen. In het luisteren formuleren we een antwoord, en al sprekend richt ik mij op het antwoord van de ander. Taal is gebed in intentie en intersubjectiviteit:

Als ik naar een ander luister terwijl hij spreekt, ben ik niet stil; ik anticipeer de woorden die hij gaat zeggen, en ik heb mijn antwoord al klaar, tenminste in ruwe vorm. Omgekeerd weet degene die spreekt impliciet dat ik hem begrijp. Een 'veld van individueel gesproken woorden" vormt zich tussen ons. De functie van de taal is slechts een aspect van de algemene relatie tussen het zelf en de anderen, die de relatie is tussen twee bewustzijnen, waarvan de ene zich in de ander projecteert.

(Ibid.:247, cursivering in origineel) $)^{\circ}$

Intersubjectiviteit is de voorwarde voor de ontwikkeling van het zelf en de erkenning van de ander als ander; zij is het fundament voor de vorming van het individu. Daarom kunnen wij met elkaar meevoelen: wij kunnen onszelf herkennen in de ander. De aanwezigheid van de ander is een bevestiging van mijzelf. Mensen reageren op elkaars woorden, gezichtsuitdrukkingen, stemmingen, omdat ze elkaar tegemoet treden als spiegelbeelden. Op hetzelfde moment bevestigt de een de identiteit of de eigenheid van de ander. Net als in de taal ligt in de bevestiging tegelijkertijd een afgrenzing besloten die ons terugwerpt op onszelf. Het leven van de ander geeft inhoud aan het mijne, maar bevestigt mij ook in mijn eigenheid. Want hoewel het kind zichzelf ziet in een ander, en spreken leert dankzij het contact met een ander, leert het al snel dat het een ander 
niet hijzelf, maar inderdaad een ander is. De ander is geen constructie van een constitutief bewustzijn, maar ik en de ander vallen evenmin met elkaar samen. De ander vertoont zich altijd aan mij als ander. Om met een ander om te kunnen gaan, om echt met elkaar verbonden te zijn, luidt het commentaar van William Hamrick, "moet er sprake zijn van gemeenschappelijkheid en gelijkheid - de ander is aanwezig als een ander ikzelfmaar, omdat de ander ook ander is, moet er ook sprake zijn van verschil en onderscheiding'. (Hamrick 1987:25, cursivering in origineel) ${ }^{1}$ Zoals in de waarneming van de dingen om ons heen tegelijkertijd de betekenis van de dingen tot stand komt, zo gaat herkenning van het ik in de ander altijd gepaard met het afbakenen van grenzen. Nooit zullen we een ander volledig begrijpen kunnen, en nooit zullen we ons ooit volledig inleven kunnen in een ander. Net zomin als ons leven in de wereld betekent dat we met de wereld samenvallen, leidt onze gerichtheid op de ander tot samensmelting met de ander. Dat laat ook de aanraking zien. Als we een ander aanraken, voelen we niet alleen de ander, maar ook de contouren van onszelf. In de aanraking van een ander ligt, net als bij de aanraking van een object, zowel het ontdekken van nieuwe betekenis als het begrenzen van het individu besloten. De aanraking van een ander voert nooit tot een volledig kennen van een ander, omdat we altijd tezelfdertijd op onze eigen grenzen stuiten en omdat we weten dat de ander ook ons voelt. Ook hier kan echter sprake zijn van kwade trouw. Als we anderen tegen hun wil aanraken, maken we hen tot object. Op dat moment ontkennen we dat de ander een lichaamsubject is, dat niet alleen gevoeld kan worden, maar in de aanraking ook altijd zelf woelt en gevoeld wordt.

Ontkenning van de dubbelzijdigheid hoeft miet altijd gepaard te gaan met geweld. De manier waarop Justus vertelt hoe hij zijn patiënten aanraakt, doet vermoeden dat hij zijn patiënten beschouwt als objecten, terwijl Daan zijn patiënten lijkt te beroeren op een manier die de dubbelzijdigheid van de aanraking volledig tot uitdrukking laat komen. Dat laatste is uiteraard alleen mogelijk als hij zijn patiënten niet tegen hun zin aanraakt.

De verhouding met de ander is dus, net als de warneming van de wereld en net als de taal, ambigu. Ambiguiteit tekent alle verhoudingen, ook die tussen artsen en patiënten. Wanneer een zieke aan een arts uitlegt dat het lijden ondraaglijk is, kan de arts tot op zekere hoogte begrijpen wat de patiënt beleeft. Maar omdat artsen zich nooit volledig inleven kunnen in de gevoelens van de patiënt, moeten zij ook proberen aan de hand van onderzoek en empirische gegevens na te gaan hoe de ziekte van een patiënt verlopen zal.

De verhouding tussen een arts en een patiënt die om euthanasie vraagt, lijkt echter gecompliceerder dan die tussen een arts en een patiënt 
die genezen wil. Niemand heeft ervaring met sterven. De eerste dood is altijd de dood van een ander. "Want hoe zou het niets dat de dood is ons kunnen raken,' schrijft Françoise Dastur, 'tenzij via de dood van een

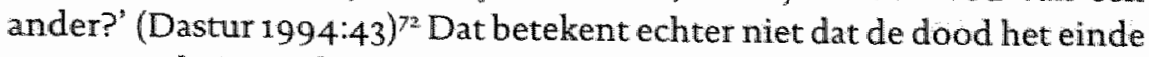
van een rellatie markeert en daardoor de intersubjectiviteit afsnijdt. 'Dit ontbreken van de ander nu wordt ervaren in de rouw,' schrijft Dastur in navolging van Merleau-Ponty, "De rouw is daarmee bij uitstek een vorm van het zijn-met-de-ander, want juist wanneer ik iemand verloren heb is de dode in grotere mate voor mij aanwezig dan een levende ooit zou kunnen zijn.' (Dastur 1994:44)73 De intersubjectiviteit die elke verhouding kenmerkt, dus ook die tussen artsen en patiënten, houdt niet op te bestaan als patiënten hun artsen te kennen geven dat zij sterven willen. Wie dat, zoals Justus, probeert te ontkennen, maakt zich schuldig aan hoogmoed.

Dat alles stelt de eis van consultatie in een nieuw licht. Ten eerste kunnen de patiënt en de arts erachter komen of de patiënt werkelijk sterven wil., of dat deze wens uit onwaarachtige motieven tot stand komt. De arts kan daarbij uit zijn of haar ervaring putten. Dat is wat dokter Daan doet. Hij maakt zijn patiënten bewust van hun echte wensen en angsten door die door henzelf zo waarachtig mogelijk te laten formuleren. Bewustwording, zegt Merleau-Ponty, "komt alleen daadwerkelijk tot stand voorzover zij door een nieuwe betrokkenheid wordt gedragen'. (MerleauPonty 1945:5197 74 De verhouding tussen een arts en een patiënt wordt niet alleen bepaald door uitleg door de dokter en begrip van de kant van de patiënt. De verhouding tussen arts en patiënt doet een nieuwe betekenis ontstaan, of, zoals Merleau-Ponty het uitdrukt, nieuwe existentiële betrekkingen. (Ibid.) Dat wil zeggen dat patiënten hun situatie anders bekijken kunnen en nieuwe antwoorden op hun vragen vinden kunnen. Maar het betekent ook dat artsen onherroepelijk betrokken zijn bij het leven en de dood van hun patiënten. Ontkennen zij dat, dan proberen zij hun patiënten als objecten te zien. Verlangen omgekeerd patiënten dat hun artsen precies doen wat zij willen, dan beschouwen zij die artsen als instrumenten. Zo zou je kunnen stellen dat in het gesprek tussen Justus en mevrouw sleutel van een dubbele kwade trouw sprake is. Justus chanteert mevrouw Sleutel, opdat die ophoudt naar dokter Daan te vragen, en mevrouw Sleutel zet met haar vraag naar dokter Daan Justus onder druk.

Maar hoe kunnen artsen met hun patiënten en collega's praten over euthanasie zonder hun patiënten te objectiveren? In feite is dat simpel: omdat ik mijzelf niet als een aan het lichaam toegevoegd bewustzijn ervaar, ervaar ik ook de ander niet zo: op primordiaal, prereflectief niveau ervaar ik hem of haar als een lichaamsubject. Wij zijn immers vanaf onze 
geboorte op de wereld en op anderen gericht, en ieder contact met de ander is een intentioneel contact. Wanneer we de ander als object denken, doen we dat op basis van de prereflectieve ervaring van de ander als lichaamsubject. We kunnen de wereld analyseren, omdat onze prereflectieve ervaring ons daartoe de mogelijkheid geeft. Aan alle twijfel en objectivering gaan primordiale vertrouwdheid met de wereld, intentie en intersubjectiviteit vooraf. Wanneer ik op anderen macht wil uitoefenen, moet ik hen eerst tot object maken. Wanneer ik dat doe, handel ik te kwader trouw: ik ontken de prereflectieve intersubjectiviteit en behandel anderen alsof zij dingen zijn. Objectiveren is een relatief ingewikkeld proces, waarbij je de natuurlijke gerichtheid op de ander negeren moet. Justus bijvoorbeeld verzint voortdurend excuses om zijn patiënten objectiveren te kunnen - hij moet er moeite voor doen. Volgens Otten maken bepaalde wetten of uitspraken het artsen makkelijk hun patiënten te objectiveren. Dat is wat er volgens Merleau-Ponty binnen de traditionele wetenschap, en dus ook binnen de medische wetenschap al te snel gebeurt. Maar dat betekent niet dat alle artsen per definitie hun patiënten tot objecten proberen te reduceren. Je zou net zo goed, of zelfs beter, kunnen zeggen dat het consult tussen arts en patiënt en tussen artsen onderling de mogelijkheid tot het objectiveren van een patiënt voorkomen moet.

Je kunt tegenwerpen dat artsen hun patiënten makkelijk overtuigen kunnen van de noodzaak euthanasie te laten toepassen, omdat veel patiënten zich nog steeds als objecten behandelen laten en veel artsen nog niet gewend zijn hun patiënten als gelijkwaardigen te beschouwen. In dat geval keren de zorgvuldigheidseisen zich tegen de patiënt. Maar je kunt ook stellen dat de zorgvuldigheidseisen nog niet ver genoeg gaan, en dat er verschillende gesprekken in verschillende situaties en periodes gehouden moeten worden, omdat onze wensen en verlangens nu eenmaal voortkomen uit de concrete situatie en niet uit een abstract idee. Maar absoluut noodzakelijk lijkt dat niet. Het is niet zo dat we niet over de dood praten kunnen. Het gaat erom hóe we over de dood praten, en vooral hoe we recht doen aan de primordiale intersubjectiviteit. Dat sommige artsen, zoals het voorbeeld van Justus zien laat, moeten leren op een meer natuurlijke, niet-objectiverende manier met hun patiënten om te gaan, is een ander probleem.

Ook artsen onderling moeten leren op een niet-objectiverende manier over hun patiënten te praten. Het gesprek tussen Justus en zijn collega over de dood van patiënt Galesloot is, zoals Justus zelf ook zegt, geen gesprek; het is een toneelspel waarin twee artsen twee goden spelen die beschikken over het lot van een mens. Otten heeft zeker ook gelijk als hij stelt dat we doen alsof we rationeel over de dood van een ander praten 
kunnen en het ons geen moeite kost een ander te helpen bij het sterven, maar dat ons dat alles in werkelijkheid in moeilijkheden brengt. We zijn inderdaad geneigd, zoals Merleau-Ponty aantoont, onze handelingen en motieven te rationaliseren. Van artsen verwachten we dat ze op een professionele manier omgaan met de dood, en zich niet laten leiden door emoties of schuldgevoelens. Maar ook dat wil niet zeggen dat we in het geval van euthanasie alleen maar kunnen kiezen tussen rationaliseringen enerzijds en tomeloze wanhoop anderzijds. We kunnen weliswar meeleven met een ander, maar altijd tot op zekere hoogte. We vallen, zoals eerder gezegd, niet met een ander samen, net zomin als we met de dingen samenvallen. Als we emoties herkennen, herkennen we de tekens ervan. De emoties van een ander, zegt Merleau-Ponty, beleven we niet, maar kunnen we wel begrijpen:

Ik neem de ander waar als gedrag; ik neem bijvoorbeeld het verdriet of de woede van een ander waar in de manier waarop hij zich gedraagt, op zijn gezicht of aan zijn handen, niet door iets aan een 'innerlijke' ervaring van leed of woede te ontlenen, maar doordat verdriet en woede variaties zijn van het 'naar de wereld zijn', die tussen lichaam en bewustzijn onverdeeld zijn, en die zich evenzeer aftekenen op het gedrag van de ander zoals dit aan zijn fenomenale lichaam zichtbaar is, als op mijn eigen gedrag zoals zich dit aan mijzelf voordoet. Maar uiteindelijk zijn het gedrag van de ander en zelfs de woorden niet de ander zelf. Het verdriet van de ander en zijn woede hebben voor hem en voor mij nooit precies dezelfde zin. Voor hem zijn het geleefde situaties, voor mij getoonde situaties.

(Ibid: 409$)^{75}$

Gesprekken over de dood betrekken ons bij het lijden van een ander. Het zou 'onecht' zijn om te doen alsof dergehijke gesprekken geen enkele invloed op ons hebben, maar het zou even onecht zijn te stellen dat ze ons per se te gronde richten. We zijn altijd tegelijk betrokken en niet-betrokken. Het heeft geen zin te beweren dat een arts in geval van euthanasie of hulp bij zelfdoding volkomen onschuldig zou zijn aan de dood van een patiënt, maar het heeft even zo weinig zin om hem of haar als alleen maar schuldig te beschouwen. 'Er is geen absolute onschuld en - om dezelfde reden - geen absolute schuld,' zegt Merleau-Ponty. 'Alle handelingen zijn een antwoord op een feitelijke situatie waarvoor we nooit volledig hebben gekozen en waarwoor we, in dit opzicht, nooit volledig verantwoordelijk zijn.' (Merleau-Ponty 1966:66) ${ }^{76}$

Absolute schuld hebben we alleen als we proberen een situatie naar onze hand te zetten en proberen te doen alsof er geen intersubjectiviteit 
bestaat. Doen we dat niet, dan is het mogelijk over de dood te praten. Sterker nog, het is zelfs nodig om over iemands doodswens te praten als we die begrijpen willen. Het spreken verhult niet, zoals Otten meent, de duistere machten die onze levens bepalen en evenmin verhult het spreken de waarheid. Er bestaan geen onafhankelijke, duistere machten in ons leven, noch één enkele waarheid. Er is geen punt nul, dat als een oerbron aan alle kennis ten grondsllag ligt en waartoe alle woorden te herleiden zijn. De betekenis ligt niet onder of achter de woorden, maar in de woorden. Betekenis ontstaat niet in de dualiteit van bewustzijn en concrete werkelijkheid, maar in de twee-eenheid van bevestiging en ontkenning, van herkenning en begrenzing, die de verhouding tussen het lichaamsubject en de concrete dingen kenmerkt. Leven is het ontstaan laten wan betekenis, of beter, het 'hernemen' van betekenis, zoals Merleau-Ponty het noemt: "Wij hebben niet de ervaring van een eeuwige waarheid en van een deelname aan het Ene, maar van de concrete akten van herneming waardoor wij, in de toevalligheden van de tijd, betrekkingen met onszelf en de ander aanknopen, kortom de ervaring van een deelname aan de wereld; het "naar-de-waarheid-zijn" onderscheidt zich niet van het naar de wereld zijn." (Merleau-Ponty 1945:452, cursivering in origineel) $)^{77}$ Woorden zijn niet slechts een omhulsel van een niet of moeilijk te kennen betekenis, net zomin als het lichaam het omhulsel is voor het bewustzijn, of de vormen van de dingen de dingen zelf verhullen. Het spreken volgt niet op het denken, maar voltrekt het. "Het benoemen van objecten,' zegt Merleau-Ponty, 'komt niet na de herkenning ervan, maar het is het herkennen zelf.' (Ibid.:207) ${ }^{78}$ Een gesprek kan daarom iemands intenties verduidelijken. Niet alleen omdat een gesprek de betekenis van een gevoel of een intentie tot uitdrukking brengen kan, maar ook omdat we in een gesprek de ander begrijpen kunnen. Ook al begrijpen anderen nooit helemaal wat ik bedoel, zij kunnen mij toch tot op zekere hoogte volgen, omdat zij zich in het luisteren naar mij richten.

Een consult, kun je daarom stellen, is niet alleen noodzakelijk voor de arts die erachter moet komen of iemand werkelijk sterven wil, maar ook van belang voor de patiënt. In een gesprek met een arts kan de patiënt zelf tot de ontdekking komen wat hij of zij werkelijk wil. Dat wil niet zeggen dat alle gesprekken tot ondubbelzinnig inzicht leiden, zowel van de kant van de patiënt als van de arts. Justus bijvoorbeeld laat mevrouw Sleutel praten, zonder dat hij naar haar luistert. Hij heeft allang besloten dat hij aan het leven van zijn patiënte een einde maken zal, zodra zij daarom vraagt. In hun gesprek probeert hij veel meer zijn positie te bevestigen dan dat hij ingaat op haar angsten en wensen. Hun gesprek zou daarom eigenlijk niet zo genoemd mogen worden: van een werkelijke dialoog is inmers geen sprake. Wanneer we een oordeel geven over een bepaalde 
handeling, zegt Merleau-Ponty, kunnen we ons nooit beroepen op a-priori vastgestelde regels. Hij vergelijkt het tot stand komen van oplossingen in morele kwesties met het proces dat een kunstenaar doormaakt: "In moraliteit, is er, net als in de kunst, geen oplossing voor degene die eerst zeker wil weten wat hij moet doen en die altijd heer over zichzelf wil blijven.' (Merleau-Ponty 1966:9) ${ }^{79}$ Morele en esthetische ervaringen zijn analoog in die zin dat de kennis van de waarden warnaar we binnen een bepaalde context streven, niet uit a-priori-regels afgeleid worden. Zo bezien leert Ons mankeert niets, anders dan Otten in zijn uitspraken over de roman stelt, dat onze bemoeienis met de dood niet per se tot onze ondergang leidt. De voorbeelden van Justus en dokter Daan laten ons zien welke gesprekken tussen patiënten en artsen 'wezenlijk' zijn, en welke we als 'onwaarachtig" beschouwen moeten.

Absolute kennis van onszelf en anderen is vanwege de ambiguiteit en de gesitueerdheid van ons bestaan niet mogelijk. Dat geldt ook voor euthanasie: nooit zullen we definitief en ondubbelzinnig weten wat het juiste is voor een patient. Achterhuis wijst terecht op het probleem van de onomkeerbaarheid van euthanasie. (Achterhuis e.a. 1995:22) Toch moeten we besluiten nemen, ook over leven en dood, simpelweg omdat de situatie waarin we ons bevinden en onze medemensen dat van ons vragen. Daarom moeten we soms handelen alsof onze besluiten de enige juiste zijn. Er is geen uiteindelijk moment van een totale, onverbeterbare duidelijkheid van onszelf en anderen, zelfs niet wanneer we sterven. We moeten handelen overeenkomstig de oordelen die we vellen over onszelf en anderen alsof ze niet weerlegbaar zijn, hoewel ze dat altijd zijn. 'De waarheid,' stelt Merleau-Ponty, 'is dat onze handelingen niet een enkel motief of een enkele uitleg toelaten [...].' (Merleau-Ponty 1966:63$64)^{80}$ Gesprekken met meerdere mensen kunnen de complexiteit van onze besluiten tot uitdrukking laten komen en de aandacht daarvoor waarborgen; ze kunnen tot erkenning van de onmogelijkheid van een 'onverbeterbare duidelijkheid' leiden, zonder dat er van een beslissing afgezien hoeft te worden. Praten over de dood is een gedeelde verantwoordelijkheid van patiënten en artsen. In die zin is die verantwoordelijkheid een verlichting van medeplichtigheid in plaats van een verzwaring ervan. Dat laat de zelfdoding van dokter Daan zien. Als dokter Daan met Justus werkelijk over zijn voornemen gepraat had, had hij Justus veel ellende besparen kunnen.

\section{Slotsom}

Merleau-Ponty noemt het leven intentioneel en intersubjectief. Wij zijn, zegt hij, vanaf onze geboorte gericht op anderen, en leren spreken, denken en handelen in onze omgang met anderen. Onze levens krijgen der- 
halve betekenis in relatie tot anderen. Dat wil echter niet zeggen dat mijn leven samenvalt met dat van een ander. De relatie tussen mensen is, net als de relatie tussen object en lichaamsubject, ambigu. In de omgang met een ander komen tegelijkertijd overeenkomsten en verschillen tot uitdrukking. Er is dus altijd sprake van gelijkheid en verschil. Dat geldt ook voor de betrokkenheid tussen arts en patiënt. De doodswens van een patiënt raakt het leven van een arts - dat te ontkennen zou betekenen dat een arts zijn patiënten als objecten ziet en de patiënt een arts als instrument. Maar een patiënt die om euthanasie vraagt, kan met die vraag alléén het leven van de arts niet te gronde richten, tenzij de arts ook zichzelf als object beschouwt.

\section{De dood als zingeving}

Als een patiënt van zestien jaar en ouder volgens de artsen uitzichtloos en ondraaglijk lijdt, maar niet meer in staat is kenbaar te maken dat hij of zij sterven wil, mogen die artsen tot euthanasie overgaan indien de patiënt in het bezit is van een schriftelijke wilsverklaring.

Otten weert zich tegen het belang dat aan dergelijke verklaringen wordt gehecht. Het voorbeeld van Justus maakt aanschouwelijk wat het gevolg van een verklaring kan zijn: meneer Galesloot heeft ooit verklaard een zachte dood te willen sterven, en zodra Justus verneemt dat meneer Galesloot door de specialisten is opgegeven, gebruikt hij die verklaring om zonder plichtplegingen een eind aan het leven van Galesloot te maken, zonder dat hij weet of meneer Galesloot op dat moment werkelijk nog sterven wil. Maar Ottens bezwaren richten zich vooral op het idee dat we de toekomst vast kunnen leggen door middel van een stukje papier. Een schriftelijke verklaring zegt hoogstens iets over hoe we ons ooit gevoeld hebben, meent hij. Nooit kan een schriftelijke verklaring iets zeggen over hoe we ons ooit zúllen voelen. Bovendien kun je volgens hem uit het gebruik van wilsverklaringen afleiden dat we de dood beschouwen als een oplossing; is een patiënt ongeneeslijk ziek, dan gebruiken we euthanasie om een einde aan zijn of haar lijden te maken, of hij of zij daar direct om vraagt of niet.

De geschriften van Merleau-Ponty lijken Otten gelijk te geven. De toekomst, als een vaststaande entiteit, bestaat volgens Merleau-Ponty niet. De mens woont in de tijd; hij wordt niet door de tijd geregeerd, net zomin als hij door een macht buiten zichzelf bepaald wordt. Het menselijk leven is in de tijd verankerd. Het lijkt daarom geen enkele zin te hebben om bij welzijn vast maatregelen te nemen voor een eventuele ziekte. In gezondheid en als we ziek zijn bevinden we ons altijd in een bepaalde 
situatie die niet van tevoren te voorzien was. Daarom zouden we, net als Otten, wilsverklaringen moeten beschouwen als nutteloos en zelfs gevaarlijk: hoe moeten we vaststellen of iemand die een aantal jaren voordat zich een ziekte openbaarde een codicil getekend heeft daadwerkelijk sterven wil? Als zieken ervaren wij onze toestand wellicht als minder ondraaglijk dan wij vreesden toen we gezond waren.

Maar zo absoluut hoeven we de gedachte aan een toekomstige toestand niet af te wijzen. Andersom geldt immers hetzelfde. Een ziekte kan vele malen ondraaglijker zijn dan wij ons ooit voorgesteld hadden. Bovendien leven we niet alleen in het heden. Verleden, heden en toekomst zijn geen onafhankelijke, statische toestanden die elkaar afwisselen. In het heden, stelt Merleau-Ponty, komen het verleden en de toekomst tot uitdrukking. De toekomst is geen doel op zich, maar we zijn wel, omdat we handelende wezens zijn, per definitie gericht op de toekomst. We mogen echter niet vergeten dat de tijd zoals wij die benoemen niet de tijd is. Afzonderlijke tijdsperioden zoals verleden, heden en toekomst zijn constructies. 'De geconstitueerde tijd, de reeks van mogelijke betrekkingen volgens wat ervoor is en wat erna komt, is niet de tijd zelf, maar de uiteindelijke registratie ervan, het eindresultaat van zijn voorbijgaan dat het objectieve denken altijd vooronderstelt en dus niet in staat is te vatten,' schrijft Merleau-Ponty. (Merleau-Ponty 1945:474, cursivering in origineel) ${ }^{81}$ De mens is principieel een temporele structuur. Wij zijn de tijd zelf. Een muziekstuk demonstreert dat de tijd een vloeiende beweging is en geen opeenvolging van tijdsperioden. Zoals een melodie niet strikt een opeenvolging van noten is, zo is de tijd niet op te delen in onafhankelijke tijdsperioden. (Vgl. Merleau-Ponty 1942:137)

Als lichaamsubject, als waarnemend, denkend en zingevend wezen, leven we in ruimte en in tijd. Niet als gevangenen van ruimte en tijd, maar als bewoners en dragers ervan. Ruimte en tijd zijn geen statische gegevens, geen denkstructuren die we tussen onszelf en de wereld plaatsen. Zo schrijft Merleau-Ponty:

Voor mijzelf ben ik niet slechts op dit precieze tijdstip, maar evenzeer op de ochtend van deze dag en op de komende nacht; en mijn heden is, zo men wil, dit ogenblik, maar het is evenzeer deze dag, dit jaar, mijn gehele leven. [...] De overgang van het heden naar een ander heden denk ik niet; ik ben er niet de toeschouwer van, maar ik voltrek deze, ik ben al bij het heden dat zal komen zoals mijn gebaar al bij zijn doel is, ik ben zelf de tijd, een tijd die 'blijvend is' en die niet 'verloopt" of "zich wijzigt', zoals Kant in enkele teksten heeft gezegd.

(Merleau-Ponty 1945:481-482) ${ }^{82}$ 
We zijn tegelijk product en producent van de zingeving; we leven in de tijd en de tijd leeft in en door ons. Een verklaring over de toekomst kan ons leven daarom een bepaalde zin geven. In die zin is een willsverklaring een uitdrukking van een huidig leven, niet van een hypothetische toekomstige toestand. Bovendien duurt het verleden in het heden voort. Een wilsverklaring is niet per definitie waardeloos, omdat zij in het verleden opgesteld is. Maar wanneer iemand een wilsverklaring tekent, simpel en alleen omdat de algemene opinie vóór het opstellen van een verklaring is, of wanneer iemand denkt te weten hoe hij of zij zich over tien of twintig jaar voelt, dan kunnen we ervan uitgaan dat er onechte motieven in het spel zijn. Tijd wordt dan niet gezien als een vloeiend geheel, maar als elkaar opvolgende tijdsblokken, waarin we ons het ene moment gezond voelen en het andere moment doodziek. Dan ontstaat een idee niet vanuit de werkelijke ervaring, maar wordt het idee over de werkelijkheid gelegd. Dan wordt, precies zoals Otten het stelt, de werkelijkheid geweld aangedaan. Als dat het geval is, makt een wilsverklaring deel uit van wat Merleau-Ponty de natuurlijke vergissing noemt: onze neiging de abstractie als belangrijker te beschouwen dan de concrete ervaring waaruit de abstractie ontstaan is.

Abstracties zijn echter, zoals gezegd, niet per se verwerpelijk. Wij ontlenen betekenis aan de wereld, maar wij geven tegelijk ook zelf de wereld betekenis. Betekenis ontstaat in de reversibele verhouding tussen subject en object. Als iemand uit angst voor toekomstig lijden een wilsverklaring tekent, kan die verklaring een bepaalde zin hebben. Omdat wij in staat zijn te abstraheren, kunnen wij een beeld vormen van de toekomst. Of dat beeld achteraf gezien klopte of niet, het kan ons hoop geven of juist angst inboezemen. Een wilsverklaring kan helpen angst voor ondraaglijke pijnen weg te nemen. Angst voor toekomstig lijden hoeft daarom niet per se "onecht" te zijn, en als we verlangen naar de 'pil van Drion' doen we dat niet per se te kwader trouw. We richten ons op wat komen gaat vanuit het huidige geleefde leven. Daarom wordt mevrouw sleutel kalmer als ze van Justus te horen krijgt dat hij haar bij het sterven zal helpen, als ze dat wil. Justus zelf handelt eerder met boze opzet: hij is bereid om mevrouw Sleutel bij het sterven te helpen, enkel en alleen omdat ze door anderen tot een ongeneeslijk zieke verklaard is. Niet haar angst laat hij gelden, maar een officiële verklaring over haar gezondheidstoestand. Hij ziet mevrouw Sleutel niet zozeer als een lijdende mens, maar als een ongeneeslijk lichaam. Voor Justus is de abstractie echter dan de werkelijkheid. Het gevolg is dat hij waarschijnlijk euthanasie zou toepassen ook als mevrouw Sleutel nog zou aarzelen. Dat gebeurde in het geval van de euthanasie van meneer Galesloot: niet zijn wens om te sterven was doorslaggevend, maar het oordeel van de artsen van het ziekenhuis. 
Maar rechtvaardigt dat alles de macht die een geschreven tekst als een wilsverklaring over ons leven hebben kan? En kunnen we de dood wel beschouwen als een mogelijke oplossing van een zich eventueel manifesterend probleem? Op het eerste gezicht lijkt deze manier om naar de dood te kijken inderdaad op een verkeerde opvatting ervan te berusten. De dood, zouden we met Otten kunnen zeggen, bestaat niet. De dood is immers net zomin als de toekomst een entiteit. De dood is het einde van een leven. Hoe kan de dood een oplossing zijn voor een eventueel toekomstig probleem?

De onmogelijkheid van de dood als oplossing wil niet zeggen dat we niet over de dood kunnen nadenken. Je kunt het leven een biologisch bestaan noemen, en de dood als niet meer dan een einde van dit bestaan beschrijven. Maar wie het leven zo noemt, abstraheert vanuit de geleefde werkelijkheid. Wie de dood als een simpel einde beschouwt, vergeet dat we het leven zin geven, omdat we weten dat we sterven zullen. De dood is altijd al in ons leven aanwezig, zoals de toekomst altijd in het heden leeft. Daarom ook heeft het net zo weinig zin mensen het tekenen van een wilsverklaring af te raden als aan te praten. Wat belangrijk is, is de manier waarop de gedachte aan de dood ons leven gestalte geven kan. De dood, zegt Merleau-Ponty, zal altijd radselachtig blijven. (1945:249-50) Niet omdat leven en dood beheerst worden door buitenmenselijke krachten, maar omdat het bewustzijn of het zelf geen transparante eenheid is die zichzelf volledig kent. Het bewustzijn is bewustzijn van iets, maar kan dat wat het zich bewust is nooit volledig kennen, omdat het daarmee niet samenvalt. Kennis en betekenis ontstaan op het onzichtbare snijvlak van de verhouding tussen mens en wereld. De mens neemt waar, maar wordt zelf ook waargenomen. Nooit staat de mens boven de dingen. Volledige kennis van leven en dood is daarom niet mogelijk.

Dit niet volledig kennen hoort bij het leven, zoals ook de dood bij het leven hoort. De tragici zijn in staat ons de raadselachtigheid en de ongrijpbaarheid van het leven te tonen, omdat zij weten dat het leven niet bestaat uit een opeenvolging van oorzaken en gevolgen. Wat dat betreft zijn de schrijvers van tragedies niet anders dan filosofen. 'Men herkent de filosoof hieraan dat bij hem onverbrekelijk samengaan: de smaak voor evidentie en de zin voor ambiguiteit,' schrijft Merleau-Ponty. 'Deze ambiguiteit heet dubbelzinnigheid wanneer de filosoof haar alleen maar ondergaat. Bij de grootste denkers wordt zij thema van onderzoek en draagt zij er toe bij onze zekerheden grond te geven, in plaats van deze te bedreigen. [...] Wat de filosoof tot filosoof makkt, is de beweging welke aldoor van kennis terugleidt naar onwetendheid en van onwetendheid naar kennis, én een zekere rust binnen deze beweging...' (Merleau-Ponty 1953:10-11, cursivering in origineel) $)^{83}$ 
Het mysterie bestaat niet buiten ons, maar leeft in ons - wij zijn de dragers ervan. Het mysterie is geen geheimzinnige, buitenaardse kracht, geen lot waaraan wij ons onderwerpen moeten, net zo min als de dood ons aangedaan wordt. Het mysterie van lewen en dood wordt niet opgeheven als we iemand helpen bij het sterven, want ook dan blijft de ambiguiteit bestaan, net zoals die uiteindelijk in de reflectie bestaan blijft. Dat betekent niet dat de dood ons wezensvreemd is. We blijven schipperen tussen weten en niet-weten. Dat geldt voor de zieke net zo goed als voor de arts, en voor de schrijver net als voor de filosoof.

Maar wie in een coma ligt, kan niet duidelijk maken wat een wilsverklaring voor hem of haar betekend heeft. Hoe kan dan een arts weten of degene die een verklaring getekend heeft, maar zich niet meer uit kan drukken, werkelijk sterven wil? Het antwoord ligt voor de hand: artsem kunnen dat nooit met zekerheid zeggen. Het enige wat zij doen kunnen, is in aanmerking nemen dat het opstellen van een wilswerklaring au fond vergelijkbaar is met het schrijven van een verhaal. Een wilsverklaring geeft, net als een verhaal, uitdrukking aan de intentionaliteit van ons bestaan. Literatuur, zegt Merleau-Ponty, is een zichtbare uitdrukking van onzichtbare betekenissen. Woorden verwijzen altijd ook naar dat wat niet wordt gezegd, net zoals bij de aanraking twee nooit volledig kenbare entiteiten waarneembaar worden. Een aanraking is zichtbaar, maar het aanraken zelf, het gevoel, de betekenis, kunnen we niet zien. Een wilsverklaring geeft, als ze niet onder dwang opgesteld is, uitdrukking aan veel meer dan een ooit op schrift gesteld idee. Zo verwijst Wiel Kusters in zijn bespreking van Ons mankeert niets naar de manier waarop we door te schrijven onze handelingen en motieven beter kunnen begrijpen: "Schrijven verheldert; de werkelijkheid dringt nu pas tot de schrijver door, nu het weten niet meer verzwegen wordt en verdrongen, maar zich in expliciete formuleringen openbaart.' (Kusters 1995:88) Artsen moeten zich bij het lezen van een wilsverklaring opstellen als goedwillende lezers van een roman. $\mathrm{Zij}$ moeten beseffen dat taal, hoe bondig ze ook kan lijken, nooit eenduidig is, simpelweg omdat de betekenis van de woorden niet in de letters ligt besloten, maar in de samenhang met andere woorden. De taal, meent Merleau-Ponty, is net als het lichaam een eenheid van materie en betekenis: 'Het is een knooppunt van levende betekenissen en geen wet van een aantal co-variante termen." (MerleauPonty $1945: 177)^{84}$

We mogen echter niet vergeten dat hoewel een schriftelijke verklaring naar een leven verwijst, ze dat leven niet is. Ze is evenmin een absolute, los van de werkelijkheid bestaande waarheid. Voor een wilsverklaring geldt hetzelfde als woor een gedicht, waarover Merleau-Ponty schrijft dat de betekenis ervan niet losstaat van de woorden en het papier waarop die 
woorden staan. Daarom mag een gedicht nooit als een abstract idee beschouwd worden:

[...] als het gedicht zich van ons vitaal gebarenspell losmaakt, maakt het zich nog niet van alle materiële ondergrond los; het zou onherstelbaar zijn verloren als zijn tekst niet precies was bewaard; de betekenis ervan is niet vrij en bevindt zich niet in de hemel van de ideeën: deze ligt ergens op een stuk kwetsbaar papier tussen de woorden ingesloten. In deze zin bestaat het gedicht, evenals elk ander kunstwerk, op de wijze van een ding en niet op de eeuwig voortdurende bestaanswijze van een waarheid.

(Ibid.:176) (15 $^{8}$

In hoeverre een geschreven tekst de essentie van een leven weergeeft, is de vraag die we ons ook stellen kunnen bij het lezen van een roman. Een roman kan de ambiguiteit van het leven weergeven, wanneer de schrijver zich erop toelegt de prereflectieve ervaring te verwoorden. We mogen echter niet vergeten dat personages zoals Justus Loef en Berend Daan personages op papier zijn. Weliswaar krijgen ze dankzij de fantasie van de schrijver en het inlevingsvermogen van de lezer een bepaalde dimensie en een bepaalde levendigheid, maar ze blijven gebonden aan het boek waarin ze voorkomen. Een roman kan de werkelijkheid tot uitdrukking brengen, maar de werkelijkheid is geen roman. Datzelfde geldt voor de filosofie. Ons mankeert niets is, grof gezegd, een hulpstuk. In die zin is de roman vergelijkbaar met de zorgvuldigheidseisen van de wet, of een schriftelijke wilsverklaring. De vraag is niet of de zorgvuldigheidseisen en schriftelijke wilsverklaringen de werkelijkheid weergeven. De enige vraag die ertoe doet is hoe we ze lezen kunnen.

\section{Slotsom}

Wie een wilsverklaring opvat als een middel om de toekomst te kunnen bezweren, heeft een verkeerde opvatting van de tijd. De toekomst bestaat niet, net zomin als het heden en verleden zelfstandige entiteiten zijn. Bovendien hebben wij geen invloed op de tijd, maar leven wij in de tijd.

Toch hoeft het opstellen van een wilsverklaring geen uitdrukking van kwade trouw te zijn. Omdat het verleden en de toekomst in het heden besloten liggen, kunnen we door middel van een wilsverklaring betekenis aan onze huidige levens geven, en daaruit troost putten. Datzelfde geldt voor de dood. Als we de dood als een instrument zien, is de dood niet meer dan een zuiver rationeel idee. Maar als we beseffen dat de dood deel uitmaakt van het leven, is er geen enkele reden om een wilsverklaring als 'onecht' te beschouwen. De wilsverklaring ten slotte hoeven we 
niet voor een absolute uitspraak aan te zien. Ze kan, net als een roman of een gedicht, een uitdrukking van de waarneming van de werkelijkheid zijn. De waarneming zelf kunnen we niet waarnemen, en om haar te doorgronden moeten we terug naar het moment waarop ze ontstaat. De literatuur en de filosofie kunnen ons daarbij helpen.

\section{Ten slotte}

Wat laat Ons mankeert niets ons in het licht van de filosofie van MerleauPonty zien, als we de roman niet als de verwoording van de morele overtuigingen van de auteur willen beschouwen, en ook niet als een simpele vertelling over het dagelijkse leven van een willekeurige huisarts? Waarin ligt de betekenis van de roman tussen wet en werkelijkheid?

Laten we allereerst vaststellen dat de lezing van de roman als tragedie, volgens Ottens opvatting van het begrip, en de historische lezing elkaar in bepaalde opzichten aanvullen. De tragische lezing laat weinig ruimte voor de dagelijksheid van de handelingen van de protagonisten, terwijl de historische lezing een al te particuliere kijk op het verhaal biedt. Waar in de ene lezing een algemeen idee te zeer op de voorgrond staat, wordt in de andere te veel naar één bepaalde situatie gekeken. Laten we vervolgens niet vergeten dat het uitgangspunt van de roman een vraag is: wat doe je als je weet dat iemand dood wil?

Op die vraag geeft het boek geen antwoord. Dat kan ook niet. Volgens Merleau-Ponty geeft een roman geen kant-en-klare antwoorden. Ons mankeert niets vertelt ons daarom niet hoe artsen reageren moeten als ze door een patiënt om euthanasie gevraagd worden. Het boek laat veeleer zien hoe het artsen vergaat die expliciet geconfronteerd worden met de ambiguiteit van ons bestaan. Tot die ambiguiteit hoort, zoals Kusters schrijft, "de spanning tussen "intimiteit" en "distantie", en die tussen "doorzichtigheid" en "ondoordringbaarheid"." (Kusters 1995:87) Justus Loef en dokter Daan moeten, zoals alle artsen in het dagelijkse leven, in het intieme contact dat ze tijdens het onderzoek met hun patienten hebben, op een bepaalde manier afstand houden en hun kennis van hun patiënten geheimhouden. Artsen die die afstand niet houden, maken hun patiënten tot objecten; artsen die te veel afstand houden, verliezen het vertrouwen van hun patiënten.

De ambiguïteit van de artsenpraktijk weerspiegelt de ambiguiteit van ons bestaan. Als lichaamsubject, zegt Merleau-Ponty, maken we deel uit van de werkelijkheid, maar transcenderen we die tegelijkertijd. De mens is als lichaamsubject het snijpunt waarop betekenis ontstaat. Intentie, intersubjectiviteit en transcendentie zijn fundamentele eigenschappen: 
in ons handelen en spreken zijn we altijd op de wereld en op anderen gericht, zonder dat we met de wereld en de ander samenvallen. De werkelijkheid is doortrokken van een beweging van herkenning en afgrenzing: in de aanraking van een object worden de grenzen van het object en van mijzelf bepaald, net zoals de betekenis van woorden in de relatie met andere woorden tot stand komt. Op die manier ontstaat ook de individuele identiteit binnen de relaties met anderen. Maar de mens kan over die relaties nadenken. Daarom zijn abstracties niet per se irreëel of 'onwaarachtig'. Pas als abstracties niet uit de werkelijke ervaring voortkomen en over de werkelijkheid heen gelegd worden, hebben we met dogma's te maken. Wie de wereld verklaren wil vanuit een dogma, handelt te kwader trouw.

Als we weten willen hoe we handelen kunnen zonder de werkelijkheid geweld aan te doen, moeten we nagaan in hoeverre onze ideeën uit de werkelijkheid voortkomen. Als artsen door een patiënt om euthanasie gevraagd worden, zullen zij moeten vaststellen of die patiënt zelfstandig tot dat besluit gekomen is, en of hij of zij daadwerkelijk uitzichtloos en ondraaglijk lijdt. Zij mogen zich daarbij niet, zoals Justus dat doet, alleen op de oordelen van anderen richten. Net als dokter Daan kunnen ze het bovengenoemde vaststellen door te proberen er in gesprekken met de patiënt achter te komen welke beslissingen aan de rationele motieven van de patiënt vooraf gegaan zijn. Gesprekken met de patiënt en met andere artsen kunnen het mogelijk maken alle betrokkenen tot een bepaald besef te laten komen van de situatie waarin de patiënt zich bevindt. Op die manier wordt voorkomen dat patiënt en artsen vanuit een opgelegd idee of een dogma handelen en zich daarmee schuldig maken aan onechte wetenschap, omdat ze het idee belangrijker vinden dan de werkelijkheid, of omdat ze, zoals de seminariegenoten van Julien Sorel in Stendhals Le rouge et le noir, 'belangrijke daden' willen verrichten ter meerdere glorie van zichzelf. Daarmee wordt ook voorkomen dat artsen hun eigen gevoelens in het contact met hun patiënten overheersen laten, iets dat zowel dokter Daan als Justus in moeilijkheden brengt.

Ons mankeert niets laat zien dat er, zoals Merleau-Ponty schrijft, 'geen absolute onschuldigheid en - om dezelfde reden - geen absolute schuld bestaat. Al onze handelingen zijn een reactie op een feitelijke situatie die we niet volledig gekozen hebben en waarvoor we, in die zin, niet volledig verantwoordelijk zijn." (Merleau-Ponty 1966:66) ${ }^{856}$ Justus en dokter Daan zijn niet perfect, noch handelen ze voortdurend te kwader trouw. Ze zijn niet volledig vrij, net zomin als ze volledig geconditioneerd zijn. Als ze fouten maken, maken ze die omdat ze de ambiguïteit van het bestaan uit het oog verloren hebben.

Ons mankeert niets, kunnen we concluderen, biedt geen vastomlijnde 
moraal. Beter dan ons op de fouten van de protagonisten te concentreren, kunnen we ons richten op het vermogen van dokter Daan om het vertrouwen van zijn patiënten te winnen, en op de manier waarop Justus ten slotte over zijn handelingen en gevoelens nadenkt en tot een beter begrip van zichzelf en zijn omgeving komt. Dat is immers precies wat de roman is: Justus" overdenking van zijn motieven en handelingen. Door te schrijven komt hij tot een begrip van wat er gebeurd is. "We openen op papier onze ogen door uit ons geheugen te putten,' schrijft Justus als hij naar zijn boot gevlucht is, 'op zoek naar onszelf, om ten slotte te begrijpen dat we sliepen toen we wakten.' (Otten 1994:138) Dat begrip verandert ons: 'We schrijven, maar als we kunnen begrijpen wat er staat zijn we niet langer die we waren toen we schrijven." (Ibid.:179) De waarde van die overdenking ligt daarin dat zij ons, zoals Justus ontdekt, duidelijk makt dat wij bestaan voor zover we met anderen samenhangen. Of, zoals Merleau-Ponty het uitdrukt, de waarde van de roman ligt daarin dat hij ons toont dat we "actief worden wat we per toeval zijn, dat wij communicatie tot stand brengen met anderen en met onszelf, waartoe onze temporele structuur ons de mogelijkheid geeft en waarvan onze vrijheid slechts een ruwe schets is'. (Merleau-Ponty $1966: 71)^{87}$ In die zin leven we tussen wet en werkelijkheid: de wet kan de structuur van de werkelijkheid tot uitdrukking laten komen. Waar wij ons voor moeten hoeden, is dat we het een ondergeschikt maken aan het ander. 


\section{Slotbeschouwing}

\section{Inleiding}

In de vorige hoofdstukken is ingegaan op de kritiek aangaande de wijze waarop in Nederland met euthanasie en hulp bij zelfdoding omgegaan wordt.

In hoofdstuk I is een beeld gegeven van de kritiek op het Nederlandse regeringsbeleid in zake euthanasie en hulp bij zelfdoding. In het buitenland werd al vóór de uitvaardiging van de wet toetsing levensbeëindiging op verzoek en zelfdoding op 12 april 2001 tegen de euthanasiepraktijk in Nederland geprotesteerd. Veel commotie veroorzaakte de VPRO-documentaire 'Dood op verzoek' uit 1994, waarin te zien is hoe de Amsterdamse arts Wilfred van Oijen een einde maakte aan het leven van zijn patiënt Cees van Wendel de Joode. Buitenlandse journalisten en politici suggereerden dat het gedoogbeleid in Nederland er binnen afzienbare tijd voor zou zorgen dat ongeneeslijk zieken zonder enige vorm van overleg door hun artsen gedood zouden worden.

Hoewel de meeste Nederlanders in de jaren negentig vóór de legalisering van euthanasie en hulp bij zelfmoord waren - in 1993 was slechts tien procent van de bevolking daartegen - klonken ook in ons land proteststemmen tegen het euthanasiebeleid. Nadat de Hoge Raad de psychiater $\mathrm{B}$. Chabot veroordeelde maar niet strafte voor de hulp bij zelfdoding van een lichamelijk gezonde vrouw, verscheen in 1994 Als de dood voor het leven, een bundel essays waarin een filosoof, een theoloog, een jurist, een psychiater en een schrijver/dichter hun bezwaren tegen de legalisering van euthanasie verwoordden. De schrijver en dichter Willem Jan Otten richt zich in deze bundel tegen de strikt rationele wijze waarop er in Nederland in het algemeen over euthanasie en hulpdoding gesproken wordt. Schuld daaraan zou de filosofie zijn, die sinds de Griekse oudheid de heerschappij overgenomen heeft van de literatuur, in het bijzonder van de tragedie. Volgens Otten hebben we sinds Plato een onbegrensd vertrouwen in de waarheid van het zuiver rationele denken, ook als het 
om vragen rond de dood gaat. Otten wijst erop dat in het euthanasiedebat voortdurend gebruik gemaakt wordt van abstracte begrippen, zoals zelfstandigheid, vrijheid en ondraaglijk lijden. Dit zijn, zegt hij, algemene begrippen die niets te maken hebben met de concrete werkelijkheid. Ons geloof in de waarheid van dergelijke begrippen heeft ertoe geleid dat wij vergeten zijn dat de mens niet vrijelijk over leven en dood beschikken kan en mag. De dood, zegt Otten, is een buitenmenselijke aangelegenheid. Wie zich daarmee inlaat, roept het noodlot over zichzelf en zijn of haar omgeving af. Volgens Otten is alleen de literatuur in staat ons dat te doen beseffen. Literatuur levert volgens hem kennis op die anders is dan 'krantenkennis'. Dat wil zeggen, in tegenstelling tot een artikel, een essay of een filosofische verhandeling brengt een roman de complexiteit van de concrete werkelijkheid tot uitdrukking. De wet met zijn abstracte bepalingen gaat aan de werkelijkheid voorbij. Bovendien laat een roman zien dat mensen hun eigen 'werk' niet zijn. (Otten 1995d:63-64) De manier waarop Otten de filosofie en de literatuur als antagonisten tegenover elkaar stelt, sluit aan bij een traditie waarin niet alleen de kennis van het zijn, maar ook kennis over de juiste manier van leven in het geding is. Binnen die traditie wordt de filosofie als het domein van de zuivere rationaliteit beschouwd en literatuur als het gebied van het gevoel en de directe ervaring.

Otten wijst op het belang van de literatuur bij medisch-ethische kwesties. Ook daarin staat hij niet alleen. Verschillende auteurs maken duidelijk dat het lezen van romans medici helpen kan bij het verbeteren van hun relatie met patiënten en het nemen van medisch-ethische beslissingen. Dat geldt ook voor de omgang met patiënten die om euthanasie of hulp bij zelfdoding vragen. Sinds de uitvaardiging van de wet euthanasie en hulp bij zelfdoding wijzen artsen en ethici op de discrepantie tussen de complexe dagelijkse werkelijkheid en de abstracte bepalingen van de wet, met name de zorgvuldigheidseisen. Gepleit wordt voor aandacht voor de verhalen van patiënten en artsen, het opnemen in de discussie van woorden die aansluiten bij de dagelijkse ervaring en een toewending tot de literatuur. In hoofdstuk II werd Ottens kritiek op de euthanasiediscussie weergegeven aan de hand van de zorgvuldigheidseisen uit de wet euthanasie en hulp bij zelfdoding.

Als weerwoord op de in zijn ogen al te rationalistische discussie schreef Otten Ons mankeert niets, een roman die hij typeerde als het gewetensonderzoek van een man die geconfronteerd wordt met de vraag wat je moet doen als je weet dat iemand dood wil. Otten noemt zijn roman zijn 'eigen gooi naar de tragedie". (Otten 1995b:48) Als we Ons mankeert niets lezen volgens Ottens definitie van een tragedie, zoals in hoofdstuk III gedaan werd, leren we dat onze complexe werkelijkheid 
bepaald wordt door buitenmenselijke krachten. Artsen die het taboe op het doden van mensen respecteren willen, zouden daarom hun patiënten moeten instrueren het woord 'euthanasie' nooit ofte nimmer in de mond te nemen.

De tragische lezing legt ons een algemeen verbod op euthanasie en hulp bij zelfdoding op. Otten beschouwt niet alleen de dood als een 'buitenmenselijke oplossing', hij stelt ook dat ons leven door het lot bepaald wordt en dat we ons aan een wet moeten aanpassen die we niet zelf gemaakt hebben. In deze lezing lijkt de discrepantie tussen wet en werkelijkheid in stand gehouden te worden.

In hoofdstuk IV stond de concrete, particuliere werkelijkheid van de personages centraal. In dit hoofdstuk werd de roman gelezen als het verhaal over een willekeurige, contemporaine arts in een willekeurig Nederlands dorp die op zijn manier met vragen betreffende euthanasie en hulp bij zelfmoord omgaat. Hij laat zich soms leiden door zijn emoties, en soms door zijn verstand, en soms gaat dat goed, en soms ook niet. Maar ook deze historische lezing is niet bevredigend, tenminste niet als we willen weten hoe ook wíj, de lezers, reageren moeten als we weten dat iemand dood wil. Waar in de tragische lezing de wet overheerst, ligt in de historische te veel nadruk op de concrete, particuliere werkelijkheid.

Dat wil niet zeggen dat Ottens roman ons niets leren kan over de wijze waarop we met de schijnbare tegenstelling tussen wet en werkelijkheid kunnen omgaan. Om de beide lezingen te integreren en te verdiepen werd in het vijfde hoofdstuk de hulp ingeroepen van de filosofie van Maurice Merleau-Ponty. Merleau-Ponty beschouwt de filosofie als een methode waarmee we de concrete, prereflectieve ervaring van het lichaam-subject tot uitdrukking brengen kunnen. In dat opzicht onderscheidt de filosofie zich volgens hem niet van de literatuur, maar vullen zij elkaar aan. Waar literatuur en filosofie de ervaring van de wereld tot uitdrukking brengen zoals die vóór de reflectie ontstaat, laat de filosofie zien wat dat betekent en hoe dat mogelijk is. Aan de hand van de filosofie van Merleau-Ponty wordt duidelijk hoe Ons mankeert niets de verwevenheid van lichaam en bewustzijn, en het algemene en het particuliere tot uitdrukking brengt.

In dit laatste hoofdstuk wordt nader ingegaan op het belang van een omgang met vragen betreffende euthanasie die recht doet aan zowel de werkelijkheid als de wet. Daarbij komt de verhouding tussen filosofie en literatuur nog eenmaal aan de orde. 
Eenzijdigheid is geen oplossing voor het probleem van de vermeende discrepantie tussen wet en werkelijkheid. Patiënten noch artsen zijn gebaat bij het strikt uitvoeren van formele regels. Van Oijen, die door Otten bekritiseerd wordt vanwege zijn vermeende absoluut geloof in zuivere rationaliteit, schreef in 1996 dat een goede omgang met het doodsverlangen van patiênten niet ligt in het pijnlijk nauwkeurig opvolgen van regels en wettelijke bepalingen:

Hoeveel regels er ook worden voorgeschreven, het zijn uiteindelijk alleen richtlijnen. In de praktijk blijkt dat deze regels geen waarborg vormen voor een goed uitgevoerde euthanasie. Je kunt je aan alle zorgvuldigheidseisen houden, de eurhanasieprocedure helemaal keurig uitvoeren en toch fouten maken. Door de nadruk te leggen op alle formele, zakelijke regelingen ben je geneigd je intuitie te negeren. Als huisarts/stervensbegeleider kun je je niet permitteren geen gehoor te geven aan je intuïtie. Het zou een zeer slechte ontwikkeling zijn als artsen zich opstellen als uitwoerders van een formele procedure. Bij iedere patiënt die om levensbeëindiging vraagt, hoort de arts zich in de eerste plaats te laten leiden door zijn gevoel en verstand, de procedure mag dit niet in de weg staan.

(Van Oijen 1996:177)

In dit citaat verzet Van Oijen zich niet tegen het gebruik van regels. Hij stelt slechts dat de regels gevoel en verstand niet overheersen mogen.

Ook Rob Dillmann maakt duidelijk dat de werkelijkheid gecompliceerder is dan de wet vermoeden doet, en dat we daarom meer nodig hebben dan algemene regels om met vragen betreffende euthanasie om te kunnen gaan. 'De reden om in te gaan op een verzoek tot euthanasie is nooit enkelvoudig,' schrijft hij:

Altijd spelen er verschillende overwegingen, waarvan sommige terug te voeren zijn op de medische toestand van de patiënt, terwijl andere geworteld zijn in de relatie tussen arts en patiënt. Het uitdrukkelijke verzoek van de patiënt is daarbij voor de arts eigenlijk nooit voldoende reden, het gaat erom dat er ook sprake is van een ondraagiijke situatie, of volgens de gecanoniseerde zorgvuldigheidseisen, van 'ondraaglijk lijden'. De draaglijkheid van het lijden kent echter geen objectieve maatstaf.

(Dillman 1998:11) 
Als artsen zich echter alleen door door hun persoonlijke gevoelens en belangen laten leiden, kunnen de belangen van hun patiënten in het gedrang komen. Dat is de angst die in het buitenland bestaat en die ook Otten verwoordt: in Nederland zou iedere ongeneeslijk zieke onverwijld en zonder overleg door zijn of haar arts gedood kunnen worden. Maar het is ook niet goed als patiënten zich bij hun beslissingen door angsten en pijnen leiden laten en om euthanasie vragen terwijl dat vanuit het gezichtspunt van de arts niet realistisch is.

De ervaringen van artsen leidden in de jaren negentig van de vorige eeuw tot een advies aan de regering. Dat advies werd omgezet in een wet, die na enkele jaren praktijkervaring aangescherpt werd. Het is niet ondenkbaar dat de discussie die op het moment over de zorgvuldigheidseisen gevoerd wordt, haar beslag krijgt in een aanpassing van de huidige wet. Een voorbeeld daarvan is het onderzoek van twee Groninger artsen naar de wijze waarop de Nederlandse rechtbanken omgaan met de euthanasie op baby's, die volgens de huidige wet verboden is. Uit hun onderzoek bleek dat dergelijke zaken in de regel geseponeerd worden. Daarop schreven de beide artsen een protocol voor pasgeborenen die ondraaglijk en uitzichtloos lijden. Op basis van de criteria die in dit protocol vastgelegd zijn, werden tot aan 2003 alle gevallen van euthanasie op baby's geseponeerd. (Verhagen, Sol, Brouwer en Sauer, 2005:183-189)

Zo is de mogelijkheid geschapen wet en werkelijkheid, het algemene en het particuliere met elkaar in overeenstemming te brengen, precies zoals dat in onze eigen levens gebeurt. "Het gezamenlijke leven wordt niet ingericht op basis van boven de tijd verheven bewuste beslissingen," schrijft Widdershoven, "maar komt tot stand in historisch gesitueerde processen van onderhandeling en overleg [...].' (Widdershoven 2000:161) Binnen die processen kan het lezen en herlezen van romans ons helpen te bepalen of onze beslissingen goed zijn , ook in het geval van euthanasie en hulp bij zelfdoding.

De filosofie van Merleau-Ponty laat zien hoe romans kunnen helpen bij het nemen van juiste beslissingen. Verhalen en romans zelf geven per definitie geen concrete richtlijnen voor het goede handelen. Een vertelling is geen verhandeling over het goede leven. Ons mankeert niets is geen blauwdruk voor de omgang met euthanasie op een manier die recht doet aan zowel wet als werkelijkheid. Als we van de roman leren willen, zijn we aangewezen op een filosofische verdieping die de roman niet ondergeschikt maakt aan een dogma.

Merleau-Ponty beschouwt filosofie en literatuur als aanvullingen op elkaar. De literatuur geeft de structuren van de concrete werkelijkheid en van de prereflectieve ervaring direct weer; de filosofie legt deze structuren bloot en maakt duidelijk hoe de literatuur ons helpen kan bij het nemen en beoordelen van beslissingen. 
Merleau-Ponty"s filosofie neemt ons mee naar de prereflectieve ervaring, die aan de reflectie ten grondslag ligt. De prereflectieve ervaring wordt gekenmerkt door ambiguiteit. Belangrijk is dat Merleau-Ponty de vorming van abstracte ideeën en wetenschappelijke theorieën niet afwijst. Hij weert zich tegen het belang dat de traditionele filosofie en natuurwetenschappen aan abstracties hechten. Hij verzet zich tegen het idee dat de reflectie werkelijker en belangrijker is dan de prereflectieve ervaring waaruit zij voortkomt. Hij laat zien dat de prereflectieve ervaring geen onderbewuste ervaring is. De prereflectieve ervaring is een lichamelijke, bewuste en talige ervaring. Intentie en intersubjectiviteit maken deel uit van de ambiguitteit. Door letterlijk terug te keren naar het moment waarop de verhouding tot stand komt tussen lichaamsubject en de wereld waarvan het lichaamsubject deel uitmaakt, kunnen we de waarde van abstracte ideeën bepalen. Als een abstract begrip niet voortkomt uit de concrete ervaring, is dit begrip onwarachtig. Wetten hoeven daarom net zomin als wetenschappelijk analyses en theorieën de prereflectieve ervaring geweld aan te doen, mits ze uit die ervaring voortkomen en niet opgedrongen worden aan de ervaring.

\section{Wat doe je als je weet dat iemand dood wil?}

Als we bedenken dat werkelijkheid en wet niet noodzakelijkerwijze met elkaar op gespannen voet staan, dan kan Ons mankeert niets ons leren hoe we op een goede, dat wil zeggen waarachtige manier kunnen omgaan met de vraag: wat doe je als je weet dat iemand dood wil? Hoe kan bijvoorbeeld een arts die door een patiënt om euthanasie gevraagd wordt erachter komen dat die patiënt vrijwillig en weloverwogen tot zijn of haar verzoek is gekomen?

Merleau-Ponty betoogt dat absolute vrijheid niet bestaat, net zomin als absolute weloverwogenheid. Dat betekent niet dat we niet in vrijheid beslissingen nemen kunnen die we als weloverwogen beschouwen kunnen. Volgen we de methode wan Merleau-Ponty, dan moeten we nagaan in hoeverre iemands verlangen naar de dood ontstaan is vanuit de concrete situatie van de patiënt. Dat wil zeggen, dan moeten we erachter zien te komen of er geen begrippen of ideeën gebruikt worden die niet uit de ervaring van de patiënt voortkomen maar er overheen gelegd worden, zoals clichés, zuiver logische redeneringen, een eerste klacht die de tweede verbergt, of overtuigingen van een ander.

Otten geeft in zijn essays voorbeelden van dergelijke opgelegde, lege uitspraken, zoals die van de actrice Mary Dresselhuys die in een interview vertelde dat ze sterven wilde als ze haar beide benen kwijt zou zijn. 
Met de werkelijkheid heeft zo'n uitspraak niets te maken. Als we onze benen niet meer hebben hoeft dat niet automatisch te leiden tot een onaanvaardbare vermindering van levenskwaliteit en levensvreugde. Bovendien kunnen we niet weten hoe wij in de toekomst op een dergelijke situatie reageren. Het is duidelijk dat een arts dergelijke uitspraken nooit als weloverwogen accepteren zal, uitzonderingen daargelaten. Maar niet alle doodswensen zijn even duidelijk te interpreteren. In Ons mankeert niets vindt Justus het begrijpelijkerwijze moeilijk om op een juiste manier in te gaan op de doodswens van dokter Daan. Dokter Daan wil, zoals Steffie zegt, gewoon dood. Hij geeft geen verklaringen en geen uitleg. Hoe kan Justus in dit geval het goede doen?

Justus, zou je kunnen zeggen, doet goed door niet te interfereren. Dokter Daans wens wordt niet ingegeven door een ander en is niet ontstaan uit onwaarachtige motieven. Dat het hier gaat om een conflict is duidelijk. Justus wil dokter Daans zelfdoding verhinderen, maar daartegen spreken allerlei overwegingen; niet in het laatst de overweging dat dokter Daan sterven wil. Dat Justus' gevoelens ambigu zijn, is begrijpelijk. Die ambiguitteit is natuurlijk, en die hoeft hem daarom niet te gronde te richten. Wat wij van dit conflict kunnen leren, is dat ons bestaan getekend is door intersubjectiviteit, maar daardoor niet per se beperkt wordt. De dood van een ander raakt ons, maar hoeft niet ons leven te verwoesten.

Wat Ons mankeert niets laat zien, is dat abstracte motieven niet het uitgangspunt mogen zijn in een gesprek tussen arts en patiënt. Beter is het als artsen samen met hun patiënten tot een motivatie van de beslissingen van de patiënten komen. Dan zouden zij meer aandacht kunnen besteden aan de tweede klacht en hun patiënten kunnen helpen hun werkelijke angsten en wensen tot uitdrukking te brengen.

Dat geldt ook voor de vraag hoe een arts kan vaststellen of een patiënte uitzichtloos en ondraaglijk lijdt. Artsen noch patiënten mogen hun toevlucht nemen tot zuiver abstracte kwalificaties. Merleau-Ponty laat zien dat artsen en patiënten kunnen weten of ze een waarachtige of een onwaarachtige uitspraak doen. In Ons mankeert niets handelt Justus te kwader trouw als hij, zoals in het geval van patiënt Galesloot, de kwalificatie van de ziekenhuisartsen voorrang geeft boven de situatie waarin de patiënt zich bevindt. Justus beseft dat hij dit doet, en hij erkent dat hij uit 'onwaarachtige motieven' handelt.

Hoe kunnen we het lijden van een ander beoordelen? Anders dan we geneigd zijn te denken, is het lijden niet zuiver subjectief. Hoewel we niet in de huid van een ander kunnen kruipen, kunnen we begrijpen hoe een ander zich voelt. Als lichaamsubjecten delen we in de totstandkoming van betekenis en zijn we altijd op de ander gericht. In 1995 publi- 
ceerde de KNMG de brochure Standpunt Hoofdbestuur KNMG inzake euthanasie. Daarin staat dat er altijd sprake moet zijn van "intersubjectieve ondraaglijkheid': artsen moeten zich kunnen invoelen in de mate van het lijden van hun patiènten. Dokter Daan laat zien wat dat betekent. Hij voelt aan wanneer er sprake is van een tweede klacht, en geeft zijn patiënten de mogelijkheid met hem over die klacht te praten.

Om dezelfde redenen kunnen gesprekken tussen arts en patiënt en tussen artsen onderling zinvol zijn, zonder dat die gesprekken de levens van de artsen ingrijpend hoeven te veranderen. Artsen moeten beseffen dat zij empathie en sympathie kunnen en moeten voelen, maar dat zij niet hun eigen dromen, angsten en wensen aan de patiënt mogen opdringen. Patiënten op hun beurt zouden niet mogen verlangen dat het leven van een arts aan hun levens ondergeschikt gemaakt wordt. Als dat wel gebeurt, is er sprake van kwade trouw. Justus lijkt een paar keer te kwader trouw te handelen, zoals wanneer hij uit ongeduld mevrouw Sleutel toezegt haar te helpen wanneer ze sterven wil. Anderzijds lijkt mevrouw Sleutel hem te chanteren door steeds naar dokter Daan te vragen. Deze voorbeelden laten zien hoe belangrijk het overleg tussen artsen is. Tijdens een overleg kunnen artsen die niet of minder bij de kwestie van de patiënt betrokken zijn, nagaan in hoeverre er sprake is van overbelasting of manipulatie.

Overleg met anderen heeft nog een voordeel. In het overleg kunnen nieuwe betekenissen ontstaan. Spreken is niet statisch: wij richten ons in het spreken altijd op onze gesprekpartners. Bovendien geeft het formuleren van onze gedachten aan die gedachten vaak weer nieuwe betekenissen. De manier waarop dokter Daan de tweede klacht bespreekbaar maakt, is hiervan een voorbeeld.

Hoe gaan we ten slotte op een goede manier om met schriftelijke wilsverklaringen? Volgens de wet mag een arts een einde maken aan het leven van patiënten die zelf niet meer duidelijk kunnen maken dat zij sterven willen, maar die in een schriftelijke verklaring vastgelegd hebben dat een arts een einde aan hun leven maken mag wanneer hun lijden uitzichtloos en onverdraaglijk geworden is. Maar hoe weten we of wilsonbekwame patiënten dezelfde mening toegedaan zijn die zij wellicht jaren tevoren hadden, toen zij de wilsverklaring tekenden?

Schriftelijke wilsverklaringen geven aan hoe iemand zich voelde op het moment dat hij of zij de verklaring opstelde. Artsen kunnen proberen dit na te gaan. Zij zouden zich op de geschiedenis van hun patiënten kunnen richten. In geen geval mogen zij tot euthanasie overgaan enkel en alleen omdat er een wilsverklaring voorligt, zoals Justus in het geval van patiënt Galesloot doet. Artsen moeten bedenken of de betreffende patiënt uit eigen beweging een verklaring getekend heeft, waarom hij of 
zij dat gedaan heeft en onder welke omstandigheden. Zij moeten nagaan wat het belang is van het vroeger gedachte voor het heden. Ook de geschiedenis van de patiënt moet meewegen in de overweging. Als alle motieven min of meer duidelijk geworden zijn, mag een wilsverklaring echter nog steeds niet de enige reden zijn om tot euthanasie over te gaan. Een wilsverklaring kan een arts helpen tot een beslissing te komen, maar een verklaring kan nooit alléén aan een beslissing ten grondslag liggen. In die zin is een wilsverklaring niet meer en minder dan een hulpmiddel.

Dat alles lijkt het opstellen van een wilsverklaring tot een futiele bezigheid te maken. Maar dat hoeft niet zo te zijn. Als Otten het schrijven van een wilsverklaring laakt, omdat we de toekomst niet kunnen beheersen, dan vergeet hij dat de toekomst in het heden besloten ligt. De tijd is niet statisch - wij verplaatsen ons niet van het verleden naar het heden en vandaar naar de toekomst. Het heden bestaat uit verleden en toekomst. Daarom kunnen we ons op de toekomst verheugen, of ons er zorgen over maken - de toekomst is vanuit het heden gezien geen onbeschreven blad. Het schrijven van een wilsverklaring kan iemand die bang is voor eventueel toekomstig lijden troost bieden. Hoewel een wilsverklaring nooit alleen doorslaggevend mag zijn bij een beslissing over euthanasie, moeten artsen wel aandacht schenken aan een wilsverklaring, ook als de patiënt wilsonbekwaam geworden is. Een wilsverklaring is de neerslag van een leven dat altijd tegelijk subjectief en intersubjectief is. Dat maakt de filosofie van Merleau-Ponty duidelijk: dat het leven in alle opzichten ambigu is en dat abstracte uitspraken, zolang we ze niet belangrijker achten dan de concrete ervaring, niet per se in tegenstelling staan tot de concrete werkelijkheid.

Een filosofisch geschrift en een roman die de prereflectieve ervaring tot uitdrukking brengen, bieden daarom geen zekerheden. Zij zijn werken zonder conclusie. De vorm van ethiek die Merleau-Ponty ons biedt is geen stelsel van pasklare antwoorden, maar belichaamt een bepaalde houding. Een roman kan ons helpen die houding in te nemen en doet ons begrijpen wanneer een beslissing of een uitspraak onwaarachtig is. Op die manier kan een roman indirect duidelijk maken wanneer een bepaling van de wet niet voortkomt uit de werkelijkheid maar aan de werkelijkheid opgedrongen wordt. De filosofie van Merleau-Ponty maakt duidelijk waarom en hoe dat kan. 



\section{Noten}

I De documentaire werd op 20 oktober 1994 in Nederland door de IKON uitgezonden.

2 Vgl. Van Oijen, 1996, p. 140.

3 Vgl. Keown, 2002 pp 138-139: "The в в ning Death on Request. A powerful letter to The Times criticised the programme as misleading in that it failed to show "wider implications of a legally permissive attitude towards euthanasia". Its signatories included Lord Walton, who chaired the House of Lords Select Committee on Medical Ethics, Lord Habgood, one of its members, and Dame Cicely Saunders, foundress of the hospice movement. The letter stated: "Having embraced the practice of euthanasia, the Dutch now find themselves on a slippery slope which not only involves euthanasia for those who are not dying but also eunthanasia without request." It concluded that "Facts from the Netherlands show clearly why euthanasia should not be legally sanctioned in this country." Volgens Van Oijen betuigde Saunders voorafgaand aan een televisieinterview met de B BC haar sympathie met zijn handelswijze: '[...] Dame Cicely Saunders, vertelde mij voor de opnames dat zij bewondering had voor de documentaire en dat zij geen tegenstander van euthanasie zou zijn als alle artsen euthanasie zouden verrichten zoals zij mij in de documentaire had zien doen.' Tijdens de uitzending overlaadde zij Van Oijen echter met verwijten. Volgens Van Oijen deed zij dit vanuit politiek oogpunt. Zij en de andere Britse gesprekspartners 'bleken er helemaal niet op uit te zijn om een discussie te voeren, maar kwamen met aanvallen waarin zij hun ongenoegen uitten over de gezondheidszorg. Zij namen de gelegenheid te baat om een pleidooi te houden voor de hospice-beweging'. (Van Oijen 1996:141)

4 Vgl. Van Oijen, 1996, p. 139.

5 'Durch die Legalisierung der aktiven Sterbehilfe und der sich damit zunehmend einschleichenden gesellschaftlichen Akzeptanz wird die mit dieser Praxis idealisierte "Freiheit zum Tode" letztlich zu einer "Unfreiheit zum Leben" pervertiert. Bei einer derartigen Legalisierung geraten zwangsläufig mehr und mehr Menschen, die trotz psychischer oder organischer Leiden und unheilbarer Krankheit weiterleben oder ihre moribunden Angehörigen am Leben lassen, wollen, in einen Rechtfer tigungszwang.'

6 In 1966 verklaarde de helft van alle Nederlands tegen de legalisering van eu- 
thanasie en hulp bij zelfdoding te zijn. In 1993 was dat nog madr tien procent. Zie Van Holsteyn en Trappenburg 1996.

7 Zie Weyers, 2002, pp 278-285. De Hoge Rad veroordeelde Chabot niet ondat hij iemand met zelfdoding geholpen had, maar omdat hij zich niet aan de officiele richijnen gehouden had; hij had het nagelaten ervoor te zorgen dat zijn patiente met een onafhankelike consulent kon spreken. Later werd hij door het Medisch Tuchtcollege berispt.

8 Volgens Willem Jan Otten is het woord 'euthanasie' een eufemisme. De manier warop in Nederland over euthanasie gesproken wordt en hoe euthanasie hier toegepast wordt, schrijft hij, makt van "de zachte dood" niets meer of minder dan hulp bij zelfdoding: "We zijn in de discussie over euthanasie allang het punt gepasseerd wadrop het alleen maar gaat over levensbeëindiging bij terminaal zieke patienten, - het onderwerp is verschoven naar wat van oudsher zelfmoord is, maar abusievelijk, met een eufemistische handnekkigheid, euthanasie blift heten. (Otten 1995d:60) Erg controversieel is deze opmerking niet, want volgens sommige auteurs maken de meeste Nederlanders geen moreel verschil tussen hulp bij zelfdoding en euthanasie. De wet, zoals die op 12 april zoo1 werd uitgevaardigd, heet "Wet toetsing levensbeëindiging op verzoek en hulp bij zelfdoding" en richt zich tuitdrukkelik op zowel levensbeëindiging op verzoek als hulp bij zelfdoding. Onder hulp bij zelfdoding wordt verstaan: "[...] het opzettelijk een ander bif zelfdoding behulpzam zijn of hem de middelen daartoe verschaffen als bedoeld in artikel 294, tweede lid, tweede volzin, Wetboek van Strafrecht." Vgl. Weyers, 2002, p.2 Vgl. ook Gerrit K. Kimsma en Evert van Leeuwen: "In the Netherlands no distinct moral difference is maintained between VAE [Voluntary Active Euthanasia] and PAS [Physician Assisted Suicide]: No difference is perceived if a physician hands over a cup to drink or gives an injection by needle: In moral terms the act is considered to be identical because intentionally and effectively they both involve actively assisting death. "Thomasma 1998:51, cursivering in origineel)

9 "The subject was human life and how to live it."

10 Vgl. bijwoorbeeld Levine, 1969 . Deze opvatting heerst ook onder niet-filosofen en niet-schrijvers. Zo schreef een lezer van NRC Handelsblad aan diezelfde krant in reactie op een artikel van $H$. Drion: "De dichter kent anders dan de wetenschapper weet." Drion 2001, p. 86, cursivering in origineel.

11 Deze zorgvuldigheidseisen zijn overgenomen uit de wet die op 1 juni 1994 van kracht werd en zijn gebaseerd op richtlijnen die de Koninklijke Nederlandsche Maatschappil tot bevordering der Geneeskunst (KNMG) in 198 非 opstelde.

12 Kenter, E.G., Struis P.E., Wassenberg H.H.: "Euthanasie is matwerk. Beoordeling wan ondraaglijk lijden is medisch domein.' Medisch Contact 58, 21 (23 mei 2003) 845-848. De betreffende alinea gat verder: 'Louter medisch gedefinieerd lijden bestaat niet. Elk lijden van de patiënt is psychisch lijden. Elke situatie rond euthanasie heeft unieke kenmerken. En dat die situatie zich in het algemeen niet gemakkelijk lat beoordelen, heeft te maken met het classificeerbaar lijden dat draaglijk en ondraaglijk kan zijn. Evenzo kan niet-classificeerbaar lijden draaglijk en ondraaglijk zijn.' 
13 King, N.M.: "The Ethics Commitree as Greek Chorus." HEC Forum, 8 (1996) $346-354$.

14 Meer Nederlandse tragedies die specifiek over euthanasie gaan, lijken nog niet geschreven te zijn. Rya Luysterberg geeft in De dood heeft alle tijd uit 1972 een geromantiseerd verslag van de doodsstrijd van har vader, die geen arts kon vinden die hem wilde euthanaseren, en Wim Ramaker schreef in 1973 een hoorspel naar anleiding van het proces tegen dokter Fostma, die een einde aan het leven van har moeder had gemaakt. Van Vonne van der Meer verscheen in 1995 een futuristisch verhaal over een oude, zieke vrouw die gedwongen wordt te sterven, en Ronald Giphart en Gérard van Kalmthout publiceerden in 1997 een toneelstuk dat geïnspireerd was door de euthanasie van zijn moeder. In het boek Het refrein is Hein van Bert Keizer uit 1994 komt euthanasie aan de orde, maar is niet het hoofdthema. Van Giphart kwam in 2000 de roman $1 k$ omhels je met duizend armen uit. Giphart zelf noemde dit boek, waarin de euthanasie van de moeder van een van de protagonisten centraal staat, een komedie. Een jaar later verscheen Nagalm van Nico Duyvestein. Dit boek begint met een verhaal over de euthanasie van de broer van de hoofdpersoon, maar dat verhal gaat al gauw over in herinmeringen aan incest. Zie ook Soeting 1996.

15 ' [...] life itself is what produces and enjoys art - and is in turn blessed or blasted by it'. (Booth 1988.7)

16 'First, philosophers have once again become poets. From Nietzsche to Heidegger, philosophical speech has no longer the transparancy of mathematical statement nor the movement which takes place in proof. Rather, it is a matter of a speaking which has a depth and vibrancy that transcends the pure thought of science, and of a style of demonstration which is based upon imaginative connection rather than former rules of procedure. But secondly, the entrance of poetry into the practise of philosophy has brought with it a concern on the part op the philosopher for what has entered into his work. The most powerful thought of our time, that of Martin Heidegger, has taken for its theme the connection of art and philosophy - and once again this connection has been thought in terms of that central rubric, "Being": (Levine $1969: 439$ )

17 "The task of that kind of philosophy cannot be distinguished from that of the novel, and novels and plays can become "philosophical" in their very being, in that the writing of a novel may be regarded as a form of phenomenological research.' (Matthews 2002: 135)

18 ' [...] Merleau-Ponty also sees the relation between the two as grounded in a common relation to Being." (Ibid.)

19 Met 'euthanasie" wordt in deze beschouwing zowel beëindiging van het leven van een ander door een arts op verzoek, als hulp bij zelfidoding bedoeld.

20 Le monde phénoménologique n'est pas l'explication d'un être préalable, mais la fondation de l'être, la philosophie n'est pas le reflet d'une vérité préalable, mais comme lart la réalisation d'une vérité." In deze beschouwing wordt geciteerd uit de Nederlandse vertaling van Phénoménologie de la perception, door Rens Vlasblom en Douwe Tiemersma (1997). Tenzij anders 
vermeld, zijn de overige vertalingen van de auteur van deze studie.

'Elle est laborieuse comme l'oeure de Balzac, celle de Proust, celle de Valéry ou celle de Cếzanne, - par le mếme genre d'attention et d"étonnement, par la même exigence de conscience, par la même volonté de saisir le sens du monde ou de l'histoire à l'état naissant.'

'Rather, a marriage of literature and traditional philosophical reflection opens the door to a richer conception of moral philosophy that can speak to the heart of what matters in a human life and character."

23 "In my own "defense", dry, highly technical, stilted writing is no prerequisite for philosophical insights, even if some very good philosophy has suffered from this malady. In such cases, the philosophy has been good in spite of the writing, and not because of it. [...] Anything worth saying is worth saying simply, clearly, and gracefully."

24 Wet toetsing levensbeëindiging op verzoek en hulp bij zelfdoding. Hoofdstuk l. bevat lbegripsomschrijvingen. Zie bijlage.

25 Gemelde gevallen van euthanasie en hulp bij zelfdoding worden getoetst door regionale toetsingscommissies. Hun samenstelling en werkwijze worden toegelicht in Hoofdstuk III van de Wet toetsing levensbeëindiging op verzoek en hulp bij zel:fdoding.

26 Hendin (1997) beweert hetzelfde. De arts van Van Wendel de Joodle schrijft echter in zijn autobiografie dat hij in het telkens verschuiven van de stervensdatum een patroon herkende. Hij hield hij er rekening mee dat zijn patiënt van zijn voomemen zou afzien. Zo schrijft hij: 'Zoals ik eerder heb beschreven, verleggen mensen hun grenzen als ze weten dat ze zelf kunnen beschikken over hun stervensuur. Dat heb ik ook met Cees besproken. Ik heb hem nadrukkelijk verteld dat het in gang zetten van de procedure voor een euthanasieverzoek niet betekende dat het tot euthanasie zou hoeven komen. In de loop van de daaropwolgende maanden zou blijken dat ook Cees de pijn langer kon verdragen dan hij had verwacht. Aanvankelijk wilde hij eind december sterven, later half januari, weer later wilde hij proberen zijn verjaardag op 3 maart nog te halen.' Toen de patiënt steeds meer achteruitging, mar de arts met hem nog wel kon overleggen, werd de euthanasieprocedure ingezet: "Toen hij half januari nog verder achteruit ging - hij kon nu alleen nog zijn linkerhand gebruiken - heb ik met hem besproken wat de procedure was die wij moesten volgen voordat ik aan zijn eventuele vraag om euthanasie kon voldoen. Het was hem daarbij volstrekt duidelijk dat dit niet betekende dat hij daardoor inderdaad door euthanasie zou sterven. Ondat hij nu nog, hoewel moeizaam, kon communiceren, was dit het moment om de procedure in gang te zetten.' (Van Oijen 1996:115, 122)

27 "De pil van Drion' wordt hier als metonymia gebruikt. Drion zelf heeft nooit van een pil gesproken, maar van "een combinatie van middelen die met een korte spanne tijds na elkar zouden moeten worden ingenomen". Vgl. Drion 2001, p. 139.

28 Onder 'taboe' verstaat Otten zowel een verbod op het noemen wan iets, als een verbod op een bepaall handelen.

29 Chabot zelf benadrukt in Zelf beschikt woortdurend dat Netty zelf verantwoordelijk was voor haar dood, omdat zij de keuze heeft gemaakt om te ster- 
ven, omdat zij hem gevraagd heeft haar van zelfmoordmiddelen te voorzien en omdat zij zelf uiteindelijk beslist heeft wanneer en hoe ze die middelen gebruikte. Zo schrijft hij bijvoorbeeld: "Mijn keuze is dat ik haar de middelen zal geven waarmee zij zich kan doden - als zij bij haar beslut blijt." (p. 9 ) en: "Ik zeg dat zij de regie heeft: Jij mag zeggen hoe het zal gebeuren." (p.95) Als Chabot Netty de middelen overhandigt, zegt hij: "Jij mag er mee doen wat je wilt." (p.108)

30 Daarmee voldoet de vorm van de roman, zoals Xandra Schutte in een recensie van Ons mankeert miets vaststelt, in elk geval aan de criteria van Aristoteles: "Aan de drie eenheden wordt voldaan: de tijd beslaat én etmaal, van het ochtendspreekuur van 28 maart tot het ochtendspreekuur van 29 maart. De roman speelt zich op één plaats af: het stadje Heimwou, waar Justus Loef een van de vier huisartsen is. De handeling staat hoofdzakelijk in het teken van het wilsbeslut van dokter Daan, van zijn wil om dood te gaan. En de jonge ants is de tragische held die in de tijdspanne van 24 uur zijn veilige wereld ineen ziet storten." (Schutte 1994)

31 Otten noemt zijn beide protagonisten 'Justus' en 'dokter Daan'; ook in deze studie wordt daarom de voornaam van de een en de achternaam van de ander gebruilkt.

32 Zoals de arts Charles Verhoeff, opleider aan de universiteit van Nijmegen en adviseur in vragen betreffende euthanasie verzoeken het uitdrukt: "Elke euthanasiewraag staat op zich en verdient zorgvuldigheid. [...] Al ben ik [arts] geworden om [mijn patiënten] beter te maken, niet om hen dood te laten gaan. Maar in de loop der jaren heb ilk geleerd dat mensen soms echt toé kunnen zijn aan de euthanasievraag.' (Bruinsma:2003)

33 Vgl. o.a. Thomasma (1998), Hoogerwerf (1999), Kennedy (2002) en Weyers (2002).

34 In 1997 besloot Wilfred van Oijen zonder overleg met andere artsen en zonder dat een wilsverklaring voorlag een patiënte, die zo ziek was dat zelfs wassen haar dood kon veroorzaken, een spierverslappend middel toe te dienen, waardoor de vrouw stierf. De directeur van het tehuis waar de vrouw verpleegd werd, maakte de zaak aanhangig. De rechtbank veroordeelde Wilfred van Oijen wegens moord, maar legde hem geen straf op. In hoger beroep eiste de adwocaat-general voor het gerechtshof negen malnden voorwardelijke celstraf. Het hof eiste in juni 2003 één week voorwardelijk. Naar aanleiding hiervan stelde Ruud Hagenouw, voorzitter van de KNMG, een uitbreiding van de zorgvuldigheidseisen voor. Vgl. Oostveen (zoo3). Op 9 november 2004 stelde de Hoge Raad in Den Haag vast dat Van Oijen zich schuldig gemaakt had aan moord. Van Oijen kreeg éen week voorwardelijke celstraf. Het hof nam de constatering van de erchtbank over, dat Van Oijen naar eer en geweten gehandeld had, maar dat hij ten onrechte een natuurlijk doodsorzalak ingevuld had op de overlijdensverklaring.

35 'Quant au roman, bien qu'il se laisse résumer, bien que la " pensée a du romancier se laisse formuler abstraitement, cette signification notionelle est prélevée sur une signification plus large, comme le signalement d'une personne est prélevé sur l'aspect concret de sa physionomie. Le romancier n"at. pas pour rôle d'exposer des idées ou même d'analyser des charactères, mais 
de présenter un événement interhumain, de le faire mûrir et éclater sans commentaire idéologique, à tel point que tout changement dans l'ordre du récit ou dans le choix des perspectives modifierait le sens romanesque de l'événement. Un roman, un poème, un tableau, un morceau du musique sont des individus, c'est à dire des êtres où l'on ne peut distinguer l'expression de l'exprimé, dont le sens n'est accessible que par un contact direct et qui rayonnent leur signification sans quitter leur place temporelle et spatiale.'

36 'Les atomes du physicien paraîtront toujours plus réels que là figure historique et qualitative de ce monde, les processus physico-chimiques plus rée]s que les formes organiques, les atomes psychiques de l'empirisme plus réels que les formes organiques, les atomes psychiques de l'empirisme plus réels que les phénomènes perçus, les atomes intellecturels que sont les * significations "de l"Ecole de Vienne plus réels que la conscience, tant que l'on cherchera à construire la figure de ce monde, la vie, la perception, l'esprit, au lieu de reconnaître, comme source toute proche et comme dernière instance de nos connaisances à leur sujet, l'experience que nous en avons.'

37 'La science manipule les choses et renonce à les habiter.' Nederlandse vertaling: Rens Vlasblom.

38 'Si ce genre de pensée prend en charge l'homme et l'histoire, et si, feignant d'ignorer ce que nous en savons par contact et par position , elle entreprend de les construire à partir de quelques indices abstraits, comme l'ont fait aus États-Unis une psychanalyse et un culturalisme décadents, puisque l'homme devient vraiment le manipulandum qu'il pense être, on entre dans un régime de culture où il n'y a plus ni vrai ni faux touchant l'homme et l'histoire, dans un sommeil ou un cauchemar dont rien ne saurait le réveiller.' Nederlandse vertaling : René Vlasblom.

39 'Descartes et surtout Kant ont délié le sujet ou la conscience en faisant voir que je ne saurais saisir aucune chose comme existante si d'abord je ne m'éprouvais existant dans l'acte de la saisir, ils ont fait paraître la conscience, l'absolue certitude de moi pour moi, comme la condition sans laquelle il n'y aurait rien du tout et l'acte de liaison comme le fondement du lié. Sans doute l'acte de liaison n"est rien sans le spectacle du monde qu'il lie, l'unité de la conscience, chez Kant, est exactement contemporaine de l"unité du monde, et chez Descares le doute méthodique ne nous fait rien perdre puisque le monde entier, au moins á titre d'expérience notre, est réintégré au Cogito, certain avec lui, et affecté seulement de l'indice " pensée de... ". Mais les relations du sujet et du monde ne sont pas rigoreusement bilatérales [...]."

40 'La science a été et reste le domaine où il faut apprendre ce qur c'est qu'une vérification, ce que cést qu' une recherche scrupuleuse, ce que c'est que la critique de soi-même et des préjugés propres. [...] Mais la question que la pensée moderne pose à son égard n'est pas destinée à lui contester l'existence ou à lui fermer aucun domaine.' Nederlandse vertaling : Jenny Slatman.

41 Merleau-Ponty erkent dat de wetenschappers sinds het einde van de negentiende eeuw "hun wetten en theorieën niet langer [...] beschouwen als een exact beeld van datgene wat zich afspeelt in de Natuur, maar als schema's die altijd veel eenvoudiger zijn dan de natuurlijke gebeurtenissen en die gecorrigeerd kunnen worden door steeds nauwkeuriger onderzoek'. (MerleauPonty 2003:37) 
42 Slatman citeert hier uit Le visible et l' imvisible (Merleau-Ponty 1964a).

43. 'N] Jus venons de voir qu' il est naturel à la conscience de se méconnaître, justement parce qu"elle est conscience des choses."

44 'Revenir aux choses mêmes, c'est revenir à ce monde avant la connalissance dont la connaissance parle toujours, et à l'égard duquel toute détermination scientifique est abstraite, signitive et dépendente, comme la géographie à l'égard du paysage où nous avons d'abord appris ce que c'est qu'une forêt, une prairie ou une rivière."

45 "Elle est laborieuse comme l'oevre de Balzac, celle de Proust, celle de Valéry ou celle de Cézanne, - par le même genre d'attention et d'étonnement, par la même exigence de conscience, par la même volonté de saisir le sens du monde ou de l'histoire à l'état naissant.'

46 '[L]'art n'est pas fait pour exposer les idées et [... la philosophie contemporaine ne consiste pas à enchaîner des concepts, mais à décrire le mélange de la conscience avec le monde, sons engagement dans un corps, sa coexistence avec les autres [... . ."

47 "[... ] un roman réussi existe non comme somme d'idées ou de thèses, mais à la manière d"une chose sensible, et d'une chose en mouvement qu'ill s'agit de percevoir dans son développenent temporel, dont il s'agit d'épouser le rythme et qui laisse dans le souvenir non pas un ensemble d'idées, mais plutôt l'ensemble et le monogramme de ces idées.' Nederlandse vertaling." Jenny Slatman.

48 'Ce ne sont pas seulement, chez les modernes, les œurres qui sons inachevées, mais le monde même tel qu'elles l'expriment est comme un ouvrage sans conclusion et dont on ne sait pas sill en comportera jamais une.' Vertaling: Jenny Slatman.

49 ". . . [ ] il est immédiatement évident que, si Pyrrhus se détournait d"Andromaque et se tournait vers Hermione, Hermione ne serait que douceur à ses pieds. Au contraire, qui peut dire si le narrateur, dans l'cuvre de Proust, aime vraiment Albertine ?'Nederlandse vertaling : Jenny Slatman

50. 'Ce que nous avons appris dans Saussure, c'est que les signes un à un ne signifiemt rien, que chacun d'eux exprime moins un sense qu'il ne marque un écart de sens entre lui-même et les autres."

51 "L... J la langue n'est pas une fonction du sujet parlant; celui-ci, engagé dans la communauté parlante, n'est pas le propriétaire de sa langue, il est tout entier volonté d'être compris et de comprendre. [... Ainsi la langue n'est pas une réalité transcendante à l'égard de tous les sujets parlants, non plus qu'une phantasme formé par l'individu. Elle est une manifestation de l"interstubjectivité humaine."

52 In de literatuur bestat een verschil in mening over de ontwikkelingsgang in het denken wan Merleat-Ponty. Volgens Jenny Slatman richt Merleau-Ponty zich in zijn wroege werk op de dialectiek tussen subject en object en het ontstaan van betekenis, terwijl hij in Le visible et "invisible de nadruk legt op de eenheid van al het werkelijke, waarin nog geen verschil tussen subject en object bestaat. In Le visible et l'invisible concentreert Merleau-Ponty zich op het gemeenschappelijke van subject en object en van subjecten onderling. Zo schrijft Slatman: "In de erwaring op het prereflectieve niveau, waar de dingen 
(en de anderen) om me heen $z i j n_{5}$ word $\mathrm{k}$ als degene die ervart ook een deal van hetgeen ik waameem, en omgekeerd wordt het waargenomene een deel van mij. Deze merkwaardige verhouding wordt aangeduid met de termen omkeerbaarheid (réversibilité), chiasma of binnendringing (empiètement)." (Slatman 1997:280) In Le wisible et linvisible draait Merleau-Ponty het warnemen (dat in de breedst mogelijke zin opgevat moet worden) als het ware binnenstebuiten om te laten zien hoe de betekenis van de wereld niet door middel van, maar door het lichaam tot stand komt. (Vgl. Slatman 1997:284) Remigius Kwant (1966) ontdekt in het latere werk van Merleau-Ponty een neiging naar de traditionele metafysische theologie. Volgens Douwe Tiemersma is Le visible et l'invisible de uitdrukking van een verandering in de ontologie in het denken van Merleau-Ponty, in which the phenomenological method, applied to the body, is abandoned in favour of a method of investigating general Being. (Tiemersma 1989:223) Rudolf Gerber neemt in het werk van Merleau-Ponty een beweging in drie algemene stappen waar. In. de eerste stap verwerpt Merleau-Ponty het empirisme en het intellectualisme ten gunste van de onderlinge afhankelijkheid van de menselijke geest en de natuur; in de tweede richt hij zich op de samenhang tussen bewustzijn, lichaam en wereld, en in de derde trekt hij bepaalde metafysische conclusies uit het voorafgaande. Gerber omschrijft het algemene doel van MerleauPonty's denken als de formulering van de prereflectieve ervaring door middel van een beschrijvende, dialectische fenomenologie van waarnemend gedrag. In die zin zou er sprake zijn van een continuïteit in het denken van Merleau-Ponty. (Gerber $1969: 84,86$ ) Ook Eugene Kealin (1970) wrijst op een continuiteit in het denken van Merleau-Ponty: Merleau-Ponty's methode de kritische reflectie - zou in zijn latere werk niet anders geweest zijn dan in het vroegere en slechts met andere woorden uitgedrukt worden.

"Tout que je sais du monde, même par science, je le sais à partir d'une vue mienne ou d'une expérience du monde sans laquelle les symboles de la science ne woudrajent rien dire. Tout l'univers de la science est construit sur le monde vécu et si nous voulons penser la science elle-même avec rigueur, en apprécier exactement le sens et la portée, il nous faut réveiller d'abord cette expérience du monde dont elle est l'expression seconde."

54 "Ce qui nous trompe là-dessus, c'est que nous cherchons souvent la liberté dans la délibération volontaire qui examine tour à tour les motifs et parât se rendre au plus fort ou au plus convaincant. En réalité, la délibération suit la décision, c'est ma décision secrète qui fait paraître les motifs et l'on ne concevrait pas tnềme ce que peut être la force d'un motif sans une décision qu'il confirme ou contrarie."

55 'C'est pourquoi, si souvent, après avoir renoncé à un projet, j'éprouve une déliverance: "Après tout, je n"y tenais pas tant ", il n'y avait débat que pour la forme, la délibération était une parodie, j"avais déjá dédicé contre.'

56 "Cle qu'il y a de métaphysique dans l'homme ne peut plus être rapporté à quelque au-delà de son être empirique, - à Dieu, à la Conscience, - c'est dans son être même, dans ses amouts, dans ses haines, dans son histoire individuelle ou collective que l'homme est métaphysique, et la métaphysique n'est plus, comme disait Descartes, l'affaire de quelques heures par mois ; elle est 
présente, comme le pensait Pascal, dans le moindre mouvement du cour.'

57 'Naître, c'est à la fois naître du monde et naître au monde. Le monde est déjà constitué, mais aussi jamais complètement constitué."

58 Te ne peux manquer la liberté que si je cherche à dépasser ma situation naturelle et sociale en refusant de l'assumer d'abord, au lieu de rejoindre à travers elle le monde naturel et humain. Rien me détermine du dehors, non que rien ne me sollicite, mais au contraire parce que je suis d'emblée hors de noi et ouvert au monde. Nous sommes de part en part urais, nous avons avec nous, du seul fait que nous sommes au monde, et non pas seulement dans le monde, comme des choses, tout ce qu'il faut pour nous dépasser."

59 'Ces pseudosolutions se reconaissent à ce que l'être de l'homme n'y coincide jamais avec ce qu'il dit, ce qu'il pense, ou même ce qu'il fait. L'art faux, la sainteté fausse, l'amour faux, qui cherchent, comme les compagnons de séminaire de Julien Sorel, à ufaire des actes significatifs", ne donnent à la vie humaine qu'une signification d'emprunt, n'opèrent qu'une transformation idéelle, une fuite dans les idées transcendentes."

60 'C'est pourqoui notre liberté ne doit pas ètre cherchée dans les discussions insincères où s'affrontent un style de vie que nous ne voulons remettre en question et des circonstances qui nous en suggèrent un autre: le choix véritable est celui de notre charactère entier et de notre manière d'être au monde."

61 ' $[A ̀]$ l'instant oǹ je me tourne vers moi-même pour me décrire, j'entrevois un flux [...] anonyme, un projet global où il n'y a pas encore $d^{*}$ "états de conscience», ni à plus forte raison de qualifications d'aucune sorte.'

62 "Je ne suis pour moi-même ni "jaloux", ni "curieux", ni "bossu", ni kfonctionnairen."

63 'On s'étonne souvent que l'infirme ou le malade puissent se supporter. C'est qu'ils ne sont pas pour eux-mêmes infirme our mourant.'

64 'Jusqu'au moment du coma, le mourant est habité par une conscience, il est tout ce qu'il voit, il a ce moyen d'échappement. La conscience ne peut jamais s'objectiver en conscience-de-malade ou conscience-d'infirme, et, même si le vieillard se plaint de sa vieillesse ou l'infirme de son infirmité, ils ne peuvent le faire que quand ils se comparent à d'autres ou quand ils se voient pas les yeux des autres, c'est-à-dire quand ils prennent d'eux-mêmes une vue statistique et objective, et ces plaintes ne sont jamais tout à fait de bonne foi: revenue au cour de sa conscience, chacun se sent au dela de ses qualifications et du coup s'y résigne.'

65 "Nous ne quittons jamais notre vie. Nous ne voyons jamais l'idée ni la liberté face à face."

66 "[C]e n’est pas moi qui voils, pas lui qü voit, q'une vision en géneral [...]." Nederlandse vertaling: Jenny Slatman

$67 \mathrm{Cf}$. een noot in de Engelse vertaling van 'La conscience et l'acquisition du langage' door Hugh Silverman : "In Jacquet's notes for Merleau-Ponty"s course on Language and Communication at the University of Lyon, we find the following passage: "Without a doubt, I a m alone in the fact of suffering and death; but is this a normal relation or is it a decomposition of the normal? It seems that in the face of death, the true essence of consciesness does not seem to express itself. Malraux has said incorrectly that 'one dies alone, 
therefore one lives alone.' In life, the essence of consciousness is communication, where one cannot determine what is ours and what belongs to others." Consciousness and the Acquisition of Language. Evanston. Northwestern Press 1973, p. 149 .

68 'Un bébé de quinze mois ouvre la bouche si je prends par jeu l'un de ses doigts entre mes dents et que je fasse mine de le mordre. Et pourtant, il n"a guère regardé son visage dans une glace, ses dents ne ressemblent pas aux miennes. C'est que sa propre bouche et ses dents, telles qu'il les sent del'intếrieur, sont d'emblée pour lui des appareils à mordre, et que ma mâchoire, telle qu'il la voit du dehors, est d'emblée pour lui capable des mêmes intentions. La « morsure " a immédiatement pour lui une signification intersubjective. Il perçoit ses intentions dans son corps, mon corps avec le sien, et par là mes intentions dans son corps.'

69 'Le mouvement de l'enfant vers la parole est un appel constant à autrui. L'enfant reconnaît dans autrui un autre lui même. Le langage est le moyen de réaliser une réciprocité avec lui. Il s'agit là d'une opération pour ainsi dire vitale, et non d'un acte intellectuel seulement. La fonction représentative est un moment de l'acte total par lequel nous entrons en communication avec autrui."

70 '[L]orsque j'écoute autrui parler, je ne suis pas sillencieux, j'anticipe déjà sur ses paroles et ma réponse est déjà au moins à l'état d'ébauce, inversement il y a chez celui qui parle croyance implicite en ma compréhension. Il s'établit entre nous un " champ de paroles $w$ individuelles. La fonction du langage n'est pas qu'un cas particulier du rapport général du moi à autrui, qui est le rapport entre deux consciences dont chacune se projette en l'autre."

71 "[...] to be genuinely related to the other, there must be a commonality and sameness - the other is present to me as another myself - but, since the other is also other, there must be difference and distinction as well.'

72 'Comment, en effet, ce rien ce qu'est la mort pourrait-il nous atteindre, si ce n'est à travers la mort de l'autre?' Nederlandse vertaling: Karin de Boer

73 'Et c'est précisément cette privation de l'autre qui est expérimentée dans le deuil, qui est un être-avec l'autre insigne, puisque, du fait même qu'on l'a perdu, le mort nous est présent plus totalement que ne le fut jamais le vivant' Nederlandse vertaling: Karin de Boer.

74. 'Il en est de même dans toutes les prises de conscience: elles ne sont effectives que si elles sont portées pas un nouvel engagement."

75 "le perçois autrui comme comportement, pas exemple je perçois le deuil ou la colère d'autrui dans sa conduite, sur son visage et sur ses mains, sans aucun emprunt à une expérience " interne in de la souffrance ou de la colère et parce què deuil et colère sont des variations de l'être au monde, indivises entre le corps et la conscience, et qui se posent aussi bien sur la conduite d'autrui, visible dans son corps phênoménal, que sur ma propre conduite telle qu'elle s'offre à moi. Mais enfin, le comportement d'autrui et mềme les paroles d'autrui ne sons pas autrui. Le deuil d'autrui et sa colère n'ont jamais exactement le même sens pour lui et pour moi. Pour lui, ce sont des situations vécues, pour moi ce sont des situations apprésentées.'

76 'Il n'y a pas d'innocence absolue et " pour la même raison, pas de culpabilité 
absolue. Toute action répond à une situation de fait que nous navons pas entièrement choisie et dont, en ce sens, nous ne sommes pas absolutement responsables."

77 "Nous avons l'expérience non pas d'un vrai éternel et d'une participation à

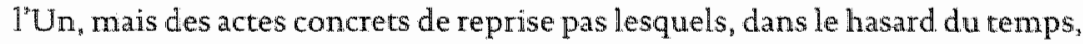
nous nouons des raport avex nous-mêmes et avec autrui, et un mot d'une participation au monde, $l^{\prime}$ "être-à-la-vérité "n"est pas distinct de l'être au monde."

78 La dénomination des objets ne wienr pas après la reconnaissance, elle est la reconnaissance même."

79 'En moralle comme en art, il n'y aurait pas de solution pour celui qui veut d'abord assurer sa marche, rester à tout instant juste et maître absolu de soimême."

80 "La vérité est que nos actions n'admettent pas un seul motif et une seule ex" plication [...].'

81 'Le temps constitué, la série des relations possibles selon l'avant et l'après, ce n'est pas le temps même, c"en est l'enregistrement final, c'est le résultat de son passage que la pensée objective présuppose toujours et ne réussit pas à saisir.'

82 "Je ne suis pas pour moi-même à l'heure qu'il est, je suis aussi bien à la matinée de ce jour ou à la nuit qui va venir, et mon présent. c'est, si l'on veut, cet instant, mais c'est aussi bien ce jour, cette année, ma vie tout entière. [. . ] Le passage du présent à un autre présent, je ne le pense pas, présent qui va venir comme mon geste est déjà à son but, je suis moi-même le temps, un temps qui " demeure "et ne "s'écoule ni ne "change " comme Kant l'a dit dans quelques textes."

83 'Le philosophe se reconnaît à ce qu'il a inséparablement le goût de l'évidence et le sens de l'ambiguité. Quand il se borne à subir l'ambiguitté, elle s"apelle équivoque. Chez les plus grands elle devient thème, elle contribue à fonder les certitudes, au lieu de les menacer. [.. . ] Ce qui fait le philosophe, c'est le mouvement qui reconduit sans cesse du savoir à l'ignorance, de l'ignorance au savoir, et une sorte de repos dans ce mouvement...'

84 "Il est un noud de significations vivantes et non pas la loi d'un certain nombre de termes covariants."

85 "[S]'il se détache de notre gesticulation vitale, le poème ne se détache pas de tout appui matériel, et il serait irrémédiablement perdu si son texte n'était exactement conservé; sa signification n'est pas libre et ne réside pas dans le ciel des idêes: elle est enfermée entre les mots sur quelque paier fragile. En cet sens-là, comme toute cuvre d'art, le poème existe à la manière d"une chose et ne subsiste pas éternellement à la manière d'une vérité."

86. "Il n'y a pas d'innocence absolue et, pour le même raison, pas de culpabilité absolue. Toute action répond ane situation de fait que nous n’avons pas entièrement choisie et dont, en ce sens, nous ne sommes pas absolument resm ponsables."

87 "Car valleur est là. Elle existe à être activement ce que nous sommes par hasard, à établir cette communication avec autrui et avec nous-mêmes dont notre structure temporelle nous offre la chance et dont notre liberté n'est que l'ébauche.' 



\section{Geraadpleegde literatuur}

Achterhuis, Hans; Goud, Johan; Koerselman, Frank; Otten, Willem Jan Schalken, Tom: Als de dood voor het leven. Over professionele hulp bij zelfmoord. Amsterdam: Van Oorschot 1995

Albrecht, Yoeri: 'Willem Jan Otten in het diepst van zijn Gedachten. "Vrij Nederland, 20-09-1997, pp 20-22

Aristoteles: Poetica. Vertaald en ingeleid door Malcolm Heath. Londen: Penguin Books Ltd. 1996

Barral, Mary Rose: The body in interpersonal relations. Merleau-Ponty. Lanham: University Press of America 1984

Beauvoir, Simone de: Une mort très douce. Parijs: Gallimard 1964. Nederlandse vertaling: Een zachte dood. Vertaald door Greetje van den Bergh. Amsterdam: Ambo 2002

Beauvoir, Simone de: L'invitée. Parijs: Gallimard 1943. Nederlandse vertaling: Uitgenodigd. Vertaald door Greetje van den Bergh. Houten: Agathon

Berghmans, Ron en Widdershoven, Guy: 'Het levenseinde laat zich niet vangen in wilsverklaringen.' NRCHandelsblad, x0-10-1997, p. 9

Blanken, Henk: "Willem Jan Otten: Soms moet je schrijven alsof je een praktijk hebt.' Nieuw Wereld Tijdschrift, 12 (1995), 52-59

Boenink, Marianne: Boekenwijsheid. Filosofie, literatuur en politieke oordeelsvorming. Amsterdam: Universiteit van Amsterdam 2000

Boer, Klaus: Maurice Merleau-Ponty - Die Entwicklung seines Strukturdenkens. Bonn: Bouvier 1978

Booth, Wayne C.: The Company We Keep. An Ethics of Fiction. Berkeley, Los Angeles: University of California Press 1988

Bruinsma, John: 'Euthanasie moet een noodoplossing blijven'. Gelderlander, 2706-2003

Buijens, Frans: Minder dood dan de anderen. Berchem: Epo 1991

Burke, Patrick en Veken, Jan van der (ted.): Merleau-Ponty in Contermporary Perspectives. Dordrecht/Boston / Londen: Kluwer Academic Publishers 1993

Cataldi, Sue: Emotion, Depth, and Flesh. A Study in Sensitive Space. Reflections on Merleau-Ponty's Philosophy of Embodiment. Albany: State University of New York Press 1993

Chabot, B.E.:

-Zelf beschikt. Amsterdam: Balans 1993 
- Sterven op drift. Nimegen: SUN 1996

- "Verlengen van leven vergt goede argumenten." NRC Handelsblad, 5-8-1997, p.7

- "Wilsverklaring kan wersterven verhelderen." NRC Handelsblad, 30-8-1997. P.7

Coles, Robert: 'The Moral Education of Medical Students." Academic Medicine, dI. $73, \mathbb{1}(1998) 55-58$

Coolsaet, Willy: Naar een filosofie van de eindigheid. Leuven/Amersfoort: Acco 1984

Corsari, Willy: De man zonder uniform. Den Haag: Leopold 1933

Cunningham, Anthony: The Heart of What Matters; the Role for Literature in Moral Philosophy. Berkeley: University of California Press 2001

Dastur, Francoise: La mort: Essai sur La fmitude. Parijs: Hatier 1994. Nederlandse vertaling: De mond van de dood. Vertaald door Karin de Boer. Amsterdam: Boom 1999 .

Deel, T, van: 'De dag begint als een kaartspel geschud door Goden. 'Trouw, 18 -1 I1994.

Dessaur, Ci.:

- Mag de dokter doden? Argumenten en documenten tegen het euthanasiasme. Amsterdam: Querido 1986

- Een gevaar dat de ziel in wil. Amsterdam: Augustus 2003

Diepstraten, Johan: "Geen emoties in roman over dorod. 'De Stem, 25-11-1994

Dillmann, R.J.M. en Legemaate J. (red.): Levensbeëindigend handelen door een arts: tussen norm en praktijk. Houten/Diegem: Bohn Stafleu Van Loghum 1998

Dillon, M.C.:

- 'A Phenomenological Conception of Truth.' Man and World, 10 (1977) 382392

- (red.): Mevleau-Ponty Vivant. Albany: State University of New York Press 1991

Douma, Joep en Widdershoven, Guy: "Euthanasie en palliatieve zorg.' NVBe Nieuwsbrief, $3(2001) 9-10$

Drion, H.: Het zelfgewilde einde van oude mensen. Amsterdam: Balans 2001

Duyvesteijn, Nico: Nagalm. Amsterdam: Arbeiderspers zoo:

Edie, James M.: Merleau-Ponty's Philosophy of Language: Structuralism and Dialectics. Boston/Londen: University Press of America 1987

Edmundson, Mark: Literature Against Philosophy, Plato to Derrida. Cambridge: Cambridge University Press 1995

Emanuel, Ezekiel: "Whose Right to Die?" The Atlantic Monthly, 279. 3 (1997) 7379

Fontaine-De Visscher, Luce: Phénomène ou structure? Essai sur le langage chez Merleau-Ponty. Brussel: Facultés universitaires Saint-Louis 1974

Geel, Rudolf: Dierbarr venijn. Amsterdam: Meulenhoff 1992

Gerber, Rudolph: 'Merleau-Ponty: The Dialectic of Conscience and World.'Man and World, 2,1 (1969) 83-107

Gerhard, William en Gupta, Brijen: 'Literature: The phenomenological art.' Mam and World, 3,2 (1970) 102-116

Giphart, Ronald en Kalmthout, Gérand van: Früsttick no future. Utrecht: $\mathbb{K}$ waw draat 1997 
Giphart, Ronald: Ik omhels je met duizend armen. Amsterdam: Podium 2000 Goedegebuure, Jaap: "De moderne doktersroman. HP/De Tijd, o2-12-1994 Grosz, Elizabeth: Wolatile Bodies. Toward a Corporal Feminism. Bloomingtom/Indianapolis: Indiana University Press 1994

Hall, Harrison: "The Continuity of Merleau-Ponty"s Philosophy of Perception." Man and World, 10 (1977) 435-447

Hamrick. William: An Existential Phenomenology of Law: Maurice MerleauPonty. Dordrecht/Boston/Lancaster: Martinus Nijhoff Publishers 1987

Hartogh, G.A. den: 'Regulering van euthanasie en hulp bij suìcide: hoe succesvol is het Nederlands model?' Tijdschrift voor Gezondheidsrecht, 4(2002) 232= 249

Heijmans, J.: 'Het formatteren van ons bewustzijn.' Filosolie Magazine, 5.9 (1996) $24-27$

Heijst, Annelies van: Verlangen naar de val. Kampen: Kok Agora 1992

Hendin, Herbert: Seduced by Death. Doctors, Patients and the Dutch Cure. New York/Londen: W.W. Norton \& Company 1997

Heumakers, Arnold: "In het web van dokter Daan: Willem Jan Otten behandelt grote zaken zonder het gebruik van "grote woorden": de Volkskrant, 25-111994

Hilhorst, H.: Euthanasie in het ziekenhuis. De 'zachte dood' bij ziekenhuispatiënten. Lochem: De Tijdstroom 1983

Holsteyn, Joop van, en Trappenburg, Margo: Het laatste oordeel. Meningen over nieuwe vormen van euthanasie. Baarn: Ambo 1996

Hoogervorst: Recensie Ons mankeert niets. De Telegraaf, $17-12-1994$

Hoogerwerf, Aart: Denken over sterven en de dood in de geneeskunde. Overwegingen van artsen bij medische beslissingen rond het levenseinde. Utrecht: Van der Wees 1999

Jauß, Hans Robert: Wege des Verstehens. München 1994

Kaelin, Eugene F:

- An Existentialist Aesthetic. Madison: The University of Wisconsin Press 1962

- Merleau-Ponty, Fundamental Ontologist." Man and World, 3,1 (1970) 102-119

Kapust, Antje: Berührung ohne Berihrung. München: Wilhelm Fink Verlag 1999

Keizer, Bert: Hetrefrein is Hein. Nijmegen: SUN 1994

Kennedy, lames: Een weloverwogen dood. Euthanasie in Nederland. Amsterdam: Bert Bakker 2002

Kenter, E.G., Struis, P.E. en Wassenberg, H.H... "Euthanasie is matwerk. Beoordeling van ondraagljk lijden is medisch domein. Medisch Contact 58, 21 (23 mei 2003$), 845-848$

Keown, John: Euthanasia, Ethics and Public Policy. An argument Against Legalislation. Cambridge: Cambridge University Press 2002

Kleinman, Arthur: The Illness Naratives. Suffering. Healing, and the Human Condition. New York: Basic Books 1988

Klijn, W.C.M.: 'Een Hollands taboe of een grond tot bezinning?' Trouw, 3 juli 1993

Kuitert, H.M.: "De warmte van een uitgebrande krater. De religiositeit van Willem Jan Otten.' NRC Handelsblad, 18-02-2000, p.7

Kusters, Wiel: "Het web is groter dan de spin. Over de roman Ons mankeert niets. 
wan Willem Jan Otten.' Tijdschrift voor Geneeskunde en Etiek, 5,3 (1995) 86 -

89

Kwant, Remigius:

- De fenomenologie van Merleau-Ponty. Utrecht/Antwerpen: Aula-boeken 1962

- From Phenomenology to Metaphysics. Pittsburgh: Duquesne University Press 1966

- Mens en expressie in het licht van de wijsbegeerte van Merleau-Ponty. Utrecht/ Antwerpen: Het Spectrum 1972

- 'Eindigen met een nieuw begin. Zien en denken in de laatste geschriften van M. Merleau-Ponty.' Tijdschrift voor Filosofie, 58,4 (1996) $717-734$

Levine, Stephen K: 'Merleau-Ponty's Phillosophy of Art' Man and World, 2,3 $(1969) 438-452$

Loetscher, Hugo: 'Die Rolle des Philosophen bei Maurice Merleau-Ponty.' du. Kulturelle Monatsschrift, 21,10 (1961) 59-61

Luysterburg, Rya: De dood heeft alle tijd. Amsterdam: De Bezige Bij 1972

Maas, P.. van der en Wal, Gerrit van der: Het levenseinde in de medische praktiyk: resultaten sterfgevallenonderzoek zoox. Voorburg: Central Bureau voor de Statistiek 2003

Madison, Gary Brent: The Phenomenology of Merleau-Ponty. A Search for the Limits of Consciousness. Athens, Ohio: Ohio University Press 1981

Matthews, Eric: The Philosophy of Merleau-Ponty. Chesham: Acumen 2002

Mattingly, Cheryl en Garro, Linda A.: Narrative and the Cultural Construction of Illness and Healing. Berkeley/Los Angeles/Londen: University of California Press 2000

Meer, Vonme van der: 'Berichten uit de bezemkast.' Tirade, mei 1995

Meijsing, Doeschka: "Biecht wan een arts: "Ons mankeert niets" door Willem Jan Otten.' Elsevier, 26-11-1994

Merleau-Ponty, Maurice :

- La structure du comportement. Parijs: Presses Universitaires de France 1942

- Phénoménologie de la perception. Parijs: Gallimard 1945. Nederlandse vertaling: Fenomenologie van de waameming. Vertald door Rens Vlasblom en Douwe Tiemersma. Amsterdam: Ambo 1997

- Humanisme et terreur. Parijs: Gallimard 1947

- Eloge de la philosophie. Leçon inaugurale au Collegge de France. Parijs: Gallimard 1953. Nederlandse vertaling: Lof der wijsbegeerte. Vertaald door E. Honée en E. Kerstiens. Meppel/Amsterdam: Boom 1979

- Les aventures de la dialectique. Parijs: Gallimard 1955

- Signes. Parijs: Gallimard 1960

- Le visible et l'invisible. Parijs: Gallimard 1964 (a)

- Loeil er l'esprit. Parijs: Gallimard 1964 (b). Nederlandse vertaling: Oog en geest: Een flosofisch essay over de waarneming in de kunst. Vertaald door Rens Vlasblom. Baarn: Ambo 1996

- La conscience et l'acquisition du langage'. Bulletin de psychologie. 236 , XV III 3-6(1964) (c), 226-259

- Sense et non-sense. Parijs: Nagel 1966

- Résumés de cours. Parijs: Gallimard 1968 
- La prose du monde. Pariys: Gallimard 1969

- Psychologie et pédagogie de l'enfant. Cours de Sorbonne. Lagrasse: Verdier 2001

- Causeries 1948. Parijs: Editions du Seuil 2002. Nederlandse vertaling: De wereld waarnemen. Vertaald door Jenny Slatman. Amsterdam: Boom 2003

Meulenberg, Frans; Meer. J. van der en Oderwald, A.K.: Ziektebeelden. Essays over literatuur en geneeskunde. Utrecht: Lemma 2002

Newton, Adam Zachary: Narrative Ethics. Cambridge/Londen: Harvard University Press 1995

Nussbaum, Martha C.:

- The Fragility of Goodness. Luck and Ethics in Greek Tragedy and Philosophy. Cambridge/New York: Cambridge University Press, 2001 (1986)

- Love"s Knowledge. Essays on Philosophy and Literature. New York/Oxford: Oxford University Press, 1992 (1990)

Oderwald, Arko; Meulenberg, Frans en Tilburg, Willem van: De taal van het gewoel (Amsterdam: Atlas 2003)

Oduncu, Fuat S. en Eisenmenger, Wolfgang: 'Geringe Lebensqualität. Die finstere Praxis der Sterbehilfe in Holland - bis hin zum Mord.' Süddeutsche Zeitung, 17-07-2003

Oijen, Wilfred van: Dilemma's wan een huisarts. Utrecht: Bruna Uitgevers B.V. 1996

Oostveen, M.: "Euthanasie soms zonder verzoek." NRC Handelsblad o6-06-2003

Osstyn, Karel: 'De cameratechniek van Willem Jan Otten. De onverwachte konkuremt. De Standaard, 10-12-1994

Otten, Willem Jan:

- 'De lust om over een leven te beschikken: Een aangekondigde zelfmoord." NRCHandelsblad, 12-11-1993 (a), cis p.2.

- 'Op de hand van de levenden: Televisie en de pil van Drion.' NRC Handelsblad, 19-11-93 (b), cs p.2

- 'De juiste keuze bestaat niet: Psychiater Chabot en de zelfmoord van Netty.' NRCHandelsblad, 3-12-1993 (c), cs p.4

- 'Een flesje Zachte Dood. Ich klage an, nazi-film over euthanasie.' NRC Handelsblad, 4*3-1994 (a), cs p.2

- "De allereerste zendgemachtigde Euthanasist." NRC Handelsblad, 28-10-1994 (b), p.2

- Deletterpiloot. Amsterdam: Van Oorschot 1994 (c)

- Ons mankeert niets. Amsterdam: Van Oorschot 1994(d)

- 'Het idee van een dood die niemand belast.' Trouw, 21-01-1995 (a)

- "Het verschuiven van schaamte." Vrij Nederland, 11-3-1995 (b), pp 46-48

- 'Sprong of val?' Frans Kellendonklezing 1995. parmentier, april 1995 (c)

- "De voorstelling van de dood als oplossing.' In: Hans Achterhuis e.a.: Als de dood voor het leven. Over professionele hulp bij zelfmoord. Amsterdam: Van Oorschot, 1995 (d). 50-70

- 'Over de erfzonde.' NRC Handelsblad, 24-12-1996, p.21

- De bedoeling van verbeelding. Zomerdagboek. Amsterdam: De Prom 2003

Oxenhandler, Neal: 'Literature As Perception in the Work of Merleau-Ponty.' In: Simon, John: Modern French Criticism. From Proust and Valéry to Structuralism. Chicago/Londen: University of Chicago Press 1972, 229-259 
Peeters, Carel: "De dokter en zijn dooddoener. Vrij Nederland, 19-11-1994

Plato: Constitutie (Politeia). Vertalld door Gerard Koolschijn. Amsterdam: Polak

\& Van Gennep 1995

Ramaker, Wim: Er is een tijd om te sterven. Kampen: Kok 1973

Ricoeur, Paul:

- La métaphore vive. Parijs: Seuil 1975

- Soi-même conme un autre. Parijs: Seuil 1990

Rozendaal, Ernst Jan: 'Alsof we greep hebben op ons eigen leven.' Provinciale

Zeeuwse Courant, 20-01-1995

Rutenfrans, Chris:

- "Het hellende vlak. Is hulp bij zelfmoord erger dan euthanasie?" Intermediair. 4. (1995) 13-15

- 'Zelfbeschikking en euthanasie.' Civis Mundi, juli 1998, 146-152

Schmidt, James: Maurice Merleau-Ponty Between Phenomenology and Structuralism. Basingstoke/Londen: Macmillan 1985

Schutte, Xandra: 'Onherstelbaar gezond." De Groene Amsterdammer, $16-11$ 1994

Slatman, Jenny:

- 'Zien en zijn. Merleau - Ponty's ontologie van ontwijkende zichtbaarheid.' In: Tiy.schrift voor Filosofie, 59,2 (1997) 276-303

- Lexpression au-delà de la représentation, Sur l'aistêsis et l'esthétique chez Merleau-Ponty. Amsterdam: Universiteit van Amsterdam 2001

- "Filosofie en de "geheime wetenschap" van de schilder - Oog en geest. Een filosofisch essay over de waarneming in de kunst.' Krisis 65 (1996) 90-94

Sluis, I. van der: Het recht om grootmoeder te doden. Amsterdam: Buyten en Schipperheyn 1977

Soeting, Monica: "Alleen als de dood onbegrijpelijk is, is hij natuurlijk." Euthanasie in de Nederlandse literatuur.' De Gids 159,1 (1996) 49-56

Spaink, Karin: Dedood in doordrukstrip. Amsterdam: Nijgh \& Van Ditmar 2001

Struyker Boudier, C.E.M.: "Genese, struktuur en zin van het verstaan. De hermeneutiek van M. Merleau-Ponty.' Merleau-Ponty, uitgave van Tijdschrift voor Filosofie, Leuven 1978

The, Anne-Mei:

- Vanawond orn 8 uur... Houten/Diegem: Bohn Stafleu Van Loghum 1997

- Palliatieve behandeling en conmunicatie. Een onderzoek naar het optimisme op herstel van longkankerpatienten. Houten/Diegem: Bohn Stafleu Van Loghum 1999

Theobald, D.: "Philosophy and Fiction. The Novel as Eloquent Philosophy.' The British Journal of Aesthetics, $14(1974) 17^{-25}$

Thomasma, David C. (red.): Asking to Die: Inside the Dutch Debate About Euthamasia. Dordrecht/Boston/Londem: Kluwer Academic Publishers 1998

Tiemersma, Douwe: Body Scheme and Body Image. An Interdisciplinary and Philosophical Studie. Amsterdam/Lisse: Swets \& Zeidlinger 1989

Tromp, Jan: "Tegen het euthanasiasme." de Volkskrant, 28-1-95, "Het Vervolg" p. $1-2$

Unger, Hellmuth: Sendung und Gewissen. Oldenburg i. O.: Stallung 194.

Vangroenweghe, Daniel, "M. Merleau-Ponty en F. de Saussure." Tijdschrift voor Filosofie $35(1973) 455-467$ 
Veken, Jan van der: 'Zien-spreken-denken.' Tijdschrift voor Filosofe, 40 (1978) 3-32

Verhagen, A.A.E.; Sol, J.J ; Brouwer, D.F. en Sauer, P.J.: 'Actieve levensbeëindiging bij pasgeborenen in Nederland. Analyse van alle 22 meldingen uit 1997/05. Nederlands Tijdschrift voor Geneeskunde, 149,4 (2005) 183-189

Vink, Ton:

- Als de dood voor de dood? Over dood, zelfdoding en hulp bij zelfdoding. Budel: Damon 2002 (a)

- 'Hulp bij zelfdoding; flosofie, praktijk en wet'. Filosofie en Praktijk, 3 (2002) $35-48(\mathrm{~b})$

Wall, Gerrit van der, e.a.: Medische besluitworming aan het einde van het leven. De praktijk en de toetsingsprocedure euthanasie. Utrecht: De Tijdstroom 2003

Weyers, Heleen: Euthanasie. Het proces van rechtsverandering. Groningen: Universiteit van Groningen 2.002

Widdershoven, Guy:

- Handelen en rationaliteit. Een systematisch overzicht van het denken van Wittgenstein, Merleau-Ponty, Gadamer en Habermas. Meppel: Boom 1987

- Principe of praktijk? Een hermeneutische visie op gezondheid en zorg. Amsterdam: Spinhex 1995

- De arts en de accountant. Het onvermogen wan principes.' In: Praktische filosofie. Utrecht: Teleac Not, (1997) 87-91

- 'Truth and Meaning in Art: Merleat-Ponty's Ambiguity.' Journal of British Society for Phenomenology, 30 (1999) 229-238

- Ethiek in de kliniek. Hedendangse benaderingen in de gezondheidsethiek. Amsterdam: Boom zooo

- 'Een zachte dood: autonomie of zorg?' In: Meulenberg, Frans e.a.: Ziektebeelden. Essays over literatuur en geneesk unde. Utrecht: Lemma 2002, 683-691

Wiggins, Osborne P.: 'Merleau-Ponty's Phenomenological Ethics.' Graduate Faculty Philosophical Journal, 10,2, 43-56

Willems, Dick: Een wereld van verschil. Pluralisme in de medische ethiek. Amsterdam: Vossiuspers Universiteit van Amsterdam 2003

Wils, Jean-Pierre: Euthanasie. Naar een ethiek van het sterven. Budel: Damon 2000

Wit, I.A. de: 'Zelfdoding op een hellend vlak: levensmoeheid geen reden voor lem vensbeëindigend handelen.' Medisch Contact, 57 (2002) 45, pp 1664-1666 



\section{Bijlage}

Wet toetsing levensbeëindiging op verzoek en hulp bij zelfdoding zoals in 2001 gepubliceerd in het Staatsblad van het Koninkrijk der Nederlanden onder nummer 194.

\section{4}

Wet van 12 april 2001, houdende toetsing van levensbeëindiging op verzoek en hulp bij zelfdoding en wijziging van het Wetboek van Strafrecht en van de Wet op de lijkbezorging (Wet toetsing levensbeëindiging op verzoek en hulp bij zelfdoding).

Wij Beatrix, bij de gratie Gods, Koningin der Nederlanden, Prinses van Oranje-Nassau, enz. enz. enz.

Allen, die deze zullen zien of horen lezen, saluut! doen weten: Alzo Wij in overweging genomen hebben, dat het wenselijk is in het Wetboek van Strafrecht een strafuitsluitingsgrond op te nemen voor de arts die met inachtneming van wettelijk vast te leggen zorgvuldigheidseisen levensbeëindiging op verzoek toepast of hulp bij zelfdoding verleent, en daartoe bij wet een meldings- en toetsings procedure vast te stellen;

Zo is het, dat Wij, de Raad van State gehoord, en met gemeen overleg der Staten-Generaal, hebben goedgevonden en verstaan, gelijk Wij goedvinden en verstaan bij deze: 
HOOFDSTUK 1 .

BEGRIPSOMSCHRIIVINGEN

Artikel 1

In deze wet wordt verstaan onder:

Onze Ministers: de Ministers van Justitie en van Volksgezondheid, Welzijnen Sport;

hulp bij zelfdoding: het opzettelijk een ander bij zelfdoding behulpzaam zijn of hem de middelen daartoe verschaffen als bedoeld in artikel 294 , tweede lid, tweede volzin, Wetboek van Strafrecht;

de arts: de arts die volgens de melding levensbeeindiging op verzoek heeft toegepast of hulp bij zelfdoding heeft verleend;

de consulent: de arts die is geraadpleegd over het voornemen van een arts om levensbeëindiging op verzoek toe te passen of hulp bij zelfdoding te verlenen;

de hulpverleners: hulpverleners als bedoeld in artikel 446, eerste lid, van boek 7 van het Burgerlijk Wetboek;

de commissie: een regionale toetsingscommissie als bedoeld in artikel 3 ; regionaal inspecteur: regionaal inspecteur van de Inspectie voor de Gezondheidszorg van het Staatstoezicht op de Volksgezondheid.

HOOFDSTUKII.

\section{ZORGVULDIGHEIDSEISEN}

Artikel 2

De zorgvuldigheidseisen, bedoeld in artikel 293, tweede lid, Wetboek van Strafrecht, houden in dat de arts:

de overtuiging heeft gekregen dat er sprake was van een vrijwillig en weloverwogen verzoek van de patiënt, de overtuiging heeft gekregen dat er sprake was van uitzichtloos en oncraaglijk lijden van de patiënt,

de patiënt heeft voorgelicht over de situatie waarin deze zich bevond en over diens vooruitzichten,

met de patiënt tot de overtuiging is gekomen dat er voor de situatie waarin deze zich bevond geen redelijke andere oplossing was, ten minste één andere, onafhankelijke arts heeft geraadpleegd, die de patiënt heeft gezien en schriftelijk zijn oordeel heeft gegeven over de zorgvuldigheidseisen, bedoeld in de onderdelen a tot en met d, en

de levensbeëindiging of hulp bij zelfdoding medisch zorgvuldig heeft uitgevoerd.

Indien de patiënt van zestien jaren of ouder niet langer in staat is zijn wil te uiten, maar voordat hij in die staat geraakte tot een redelijke waarde- 
ring van zijn belangen terzake in staat werd geacht, en een schriftelijke verklaring, inhoudende een verzoek om levensbeëindiging, heeft afgelegd, dan kan de arts aan dit verzoek gevolg geven. De zorgvuldigheidseisen, bedoeld in het eerste lid, zijn van overeenkomstige toepassing. Indien de minderjarige patiënt een leeftijd heeft tussen de zestien en achttien jaren en tot een redelijke waardering van zijn belangen terzake in staat kan worden geacht, kan de arts aan een verzoek van de patiënt om levensbeëindiging of hulp bij zelfdoding gevolg geven, nadat de ouder of de ouders die het gezag over hem uitoefent of uitoefenen dan wel zijn voogd bij de besluitvorming zijn betrokken.

Indien de minderjarige patiënt een leeftijd heeft tussen de twaalf en zestien jaren en tot een redelijke waardering van zijn belangen terzake in staat kan worden geacht, kan de arts, indien een ouder of de ouders die het gezag over hem uitoefent of uitoefenen dan wel zijn woogd zich met de levensbeëindiging of hulp bij zelfdoding kan of kunnen verenigen, aan het verzoek van de patiënt gevolg geven. Het tweede lid is van overeenkomstige toepassing.

\section{HOOFDSTUK III.}

REGIONALE TOETSINGSCOMMISSIES VOOR LEVENSBEËINDIGING OP VERZOEK EN HULP BIJ ZELFDODING Paragraaf 1: Instelling, samenstelling en benoeming

\section{Artikel $_{3}$}

Er zijn regionale commissies voor de toetsing van meldingen van gevallen van levensbeëindiging op verzoek en hulp bij zelfdoding als bedoeld in artikel 293, tweede lid, onderscheidelijk 294, tweede lid, tweede volzin, van het Wetboek van Strafrecht.

Een commissie bestaat uit een oneven aantalleden, waaronder in elk geval één rechtsgeleerd lid, tevens voorzitter, één arts en én deskundige inzake ethische of zingevingsvraagstukken. Van een commissie maken mede deel uit plaatsvervangende leden van elk van de in de eerste volzin genoemde categorieën.

\section{Artikel 4}

De voorzitter en de leden, alsmede de plaatsvervangende leden worden door Onze Ministers benoemd voor de tijd van zes jaar. Herbenoeming kan eenmaal plaatsvinden voor de tijd van zes jaar.

Een commissie heeft een secretaris en één of meer platsvervangend secretarissen, allen rechtsgeleerden, die door Onze Ministers worden benoemd. De secretaris heeft in de vergaderingen van de commissie een raadgevende stem. 
De secretaris is voor zijn werkzaamheden voor de commissie uitsluitend verantwoording schuldig aan de commissie.

Paragraaf 2: Ontslag

\section{Artikel 5}

De voorzitter en de leden, alsmede de plaatsvervangende leden kunnen te allen tijde op hun eigen verzoek worden ontslagen door Onze Ministers.

\section{Artikel 6}

De voorzitter en de leden, alsmede de plaatsvervangende leden kunnen door Onze Ministers worden ontslagen wegens ongeschiktheid of onbekwaamheid of op andere zwaarwegende gronden.

\section{Paragraaf 3 : Bezoldiging}

\section{Artikel 7}

De voorzitter en de leden alsmede de plaatsvervangende leden ontvangen vacatiegeld alsmede een vergoeding voor de reis- en verblijfkosten volgens de bestaande rijksregelen, voor zover niet uit anderen hoofde een vergoeding voor deze kosten wordt verleend uit "s Rijks kas.

\section{Paragraaf 4 : Taken en bevoegdheden}

\section{Artikel 8}

De commissie beoordeelt op basis van het verslag bedoeld in artikel 7 , tweede lid, van de Wet op de lijkbezorging, of de arts die levensbeëindiging op verzoek heeft toegepast of hulp bij zelfdoding heeft verleend, heeft gehandeld overeenkomstig de zorgvuldigheidseisen, bedoeld in artikel 2.

De commissie kan de arts verzoeken zijn verslag schriftelijk of mondeling aan te vullen, indien dit voor een goede beoordeling van het handelen van de arts noodzakelijk is.

De commissie kan bij de gemeentelijke lijkschouwer, de consulent of de betrokken hulpverleners inlichtingen inwinnen, indien dit voor een goede beoordeling van het handelen van de arts noodzakelijk is.

\section{Artikel 9}

De commissie brengt haar gemotiveerde oordeel binnen zes weken na ontvangst van het verslag als bedoeld in artikel 8 , eerste lid, schriftelijk ter kennis van de arts.

De commissie brengt haar oordeel ter kennis van het College van procu- 
reurs-generaal en de regionaal inspecteur voor de gezondheidszorg: indien de arts naar het oordeel van de commissie niet heeft gehandeld overeenkomstig de zorgvuldigheidseisen, bedoeld in artikel 2; of indien de situatie zich voordoet als bedoeld in artikel 12, laatste volzin van de Wet op de lijkbezorging.

De commissie stelt de arts hiervan in kennis.

De in het eerste lid genoende termijn kan eenmaal voor ten hoogste zes weken worden verlengd. De commissie stelt de arts hiervan in kennis.

De commissie is bevoegd het door haar gegeven oordeel mondeling tegenover de arts nader toe te lichten. Deze mondelinge toelichting kan plaatsvinden op verzoek van de commissie of op verzoek van de arts.

\section{Artikel ro}

De commissie is verplicht aan de officier van justitie desgevraagd alle inlichtingen te verstrekken, welke hij nodig heeft:

ten behoeve van de beoordeling van het handelen van de arts in het geval als bedoeld in artikel 9 , tweede lid; of

ten behoeve van een opsporingsonderzoek.

Van het verstrekken van inlichtingen aan de officier van justitie doet de commissie mededeling aan de arts.

\section{Paragraaf 6: Werkwijze}

\section{Artikel 11}

De commissie draagt zorg voor registratie van de ter beoordeling gemelde gevallen van levensbeëindiging op verzoek of hulp bij zelfdoding. Bij ministeriële regeling van Onze Ministers kunnen daaromtrent nadere regels worden gesteld.

\section{Artikel 12}

Een oordeel wordt vastgesteld bij gewone meerderheid van stemmen. Een oordeel kan slechts door de commissie worden vastgesteld indien alle leden van de commissie aan de stemming hebben deelgenomen.

\section{Artikel 13}

De voorzitters van de regionale toetsingscommissies voeren ten minste twee maal per jaar overleg met elkaar over werkwijze en functioneren van de commissies. Bij het overleg worden uitgenodigd een vertegenwoordiger van het College van procureurs-generaal en een vertegenwoordiger van de Inspectie voor de Gezondheidszorg van het Staatstoezicht op de Volksgezondheid. 
Artikel 14

De leden en platsvervangend leden van de commissie zijn verplicht tot geheimhouding wan de gegevens waarover zij bij de taakuitvoering de beschikking krijgen, behoudens voor zover enig wettelijk voorschrift hen tot mededeling verplicht of uit hun taak de noodzaak tot mededeling voortvloeit.

\section{Artikel 15}

Een lid van de commissie, dat voor de behandeling van een zaak zitting heeft in de commissie, verschoont zich en kan worden gewraakt indien er feiten of omstandigheden bestaan waardoor de onpartijdigheid van zijn oordeel schade zou kunnen lijden.

\section{Artikel 16}

Een lid, een plaatsvervangend lid en de secretaris van de commissie onthouden zich van het geven van een oordeel over het voornemen van een arts om levensbeëindiging op verzoek toe te passen of hulp bij zelfdoding te verlenen.

\section{Paragraaf 8: Rapportage}

Artikel 17

De commissies brengen jaarlijks vóór 1 april aan Onze Ministers een gezamenlijk verslag van werkzaamheden uit over het afgelopen kalenderjaar. Onze Ministers stellen hiervoor bij ministeriële regeling een model vast.

Het in het eerste lid bedoelde verslag van werkzaamheden vermeldt in ieder geval:

het aantal gemelde gevallen van levensbeëindiging op verzoek en hulp bij zelfdoding waarover de commissie een oordeel heeft uitgebracht; de aard van deze gevallen;

de oordelen en de daarbij gemaakte afwegingen.

\section{Artikel 18}

Onze Ministers brengen jaarlijks ter gelegenheid van het indienen van de begroting aan de Staten-Generaal verslag uit met betrekking tot het functioneren van de commissies naar aanleiding van het in het artikel 17, eerste lid, bedoelde verslag van werkzaamheden. 


\section{Artikel 19}

Op voordracht van Onze Ministers worden bij algemene maatregel van bestuur met betrekking tot de commissies regels gesteld betreffende hun aantal en relatieve bevoegdheid;

hun vestigingsplaats.

Bij of krachtens algemene maatregel van bestuur kunnen Onze Ministers met betrekking tot de commissies nadere regels stellen betreffende hun omvang en samenstelling; hun werkwijze en verslaglegging.

HOOFDSTUKIV.

WIJZIGINGEN IN ANDERE WETTEN

Artikel 20

Het Wetboek van Strafrecht' wordt als volgt gewijzigd.

A

Artikel 293 komt te luiden:

Artikel 293

Hij die opzettelijk het leven van een ander op diens uitdrukkelijk en ernstig verlangen beëindigt, wordt gestraft met een gevangenisstraf van ten hoogste twaalf jaren of geldboete van de vijfde categorie.

Het in het eerste lid bedoelde feit is niet strafbaar, indien het is begaan door een arts die daarbij voldoet aan de zorgvuldigheidseisen, bedoeld in artikel 2 van de Wet toetsing levensbeëindiging op verzoek en hulp bij zelfdoding en hiervan mededeling doet aan de gemeentelijke lijkschouwer overeenkomstig artikel 7, tweede lid, van de Wet op de lijkbezorging.

B

Artikel 294 komt te luiden:

Artikel 294

Hij die opzettelijk een ander tot zelfdoding aanzet, wordt, indien de zelfdoding volgt, gestraft met een gevangenisstraf van ten hoogste drie jaren of geldboete van de vierde categorie.

Hij die opzettelijk een ander bij zelfdoding behulpzaam is of hem de middelen daartoe verschaft, wordt, indien de zelfdoding volgt, gestraft met een gevangenisstraf van ten hoogste drie jaren of geldboete van de vierde categorie. Artikel 293, tweede lid, is van overeenkomstige toepassing. 
In artikel 295 wordt na "293" toegevoegd:, eerste lid,.

D

In artikel 422 wordt na " 293 " toegevoegd: , eerste lid,.

Artikel 21

De Wet op de lijkbezorging wordt als volgt gewijzigd.

A

Artikel 7 komt te luiden:

Artikel 7

Hij die de schouwing heeft verricht geeft een verklaring van overlijden af, indien hij ervan overtuigd is dat de dood is ingetreden ten gevolge van een natuurlijke oorzaak.

Indien het overlijden het gevolg was van de toepassing van levensbeëindiging op verzoek of hulp bij zelfdoding als bedoeld in artikel 293, tweede, onderscheidenlijk artikel 294, tweede lid, tweede volzin, van het Wetboek van Strafrecht, geeft de behandelende arts geen verklaring van overlijden af en doet hij van de oorzaak van dit overlijden onverwijld door invulling van een formulier mededeling aan de gemeentelijke lijkschouwer of een der gemeentelijke lijkschouwers. Bij de mededeling voegt de arts een beredeneerd verslag inzake de inachtneming van de zorgvuldigheidseisen, bedoeld in artikel 2 van de Wet toetsing levensbeëindiging op verzoek en hulp bij zelfdoding.

Indien de behandelende arts in andere gevallen dan die bedoeld in het tweede lid meent niet tot afgifte van een verklaring van overlijden te kunnen overgaan, doet hij hiervan onverwijld door invulling van een formulier mededeling aan de gemeentelijke lijkschouwer of een der gemeentelijke lijkschouwers.

B

Artikel 9 komt te luiden:

Artikel 9

De vorm en de inrichting van de modellen van de verklaring van overlijden, af te geven door de behandelende arts en door de gemeentelijke lijkschouwer, worden geregeld bij algemene maatregel van bestuur.

De vorm en de inrichting van de modellen van de mededeling en het verslag, bedoeld in artikel 7 , tweede lid, van de mededeling bedoeld in artikel 7 , derde lid en van de formulieren bedoeld in artikel 10, eerste en 
tweede lid, worden geregeld bij algemene maatregel van bestuur op voordracht van Onze Minister van Justitie en Onze Minister van Volksgezondheid, Welzijn en Sport.

C

Artikel 1o komt te luiden:

Artikel 10

Indien de gemeentelijke lijkschouwer meent niet tot afgifte van een verklaring van overlijden te kunnen overgaan, brengt hij door invulling van een formulier onverwijld verslag uit aan de officier van justitie en waarschuwt hij onverwijld de ambtenaar van de burgerlijke stand.

Onverminderd het eerste lid brengt de gemeentelijke lijkschouwer, in dien sprake is van een mededeling als bedoeld in artikel 7 , tweede lid, door invulling van een formulier onverwijld verslag uit aan de regionale toetsingscommissie bedoeld in artikel 3 van de Wet toetsing levensbeëindiging op verzoek en hulp bij zelfdoding. Hij zendt het beredeneerd verslag als bedoeld in artikel 7 , tweede lid, mee.

$\mathrm{D}$

Aan artikel 12 wordt een volzin toegevoegd, luidende: Indien de officier van justitie in de gevallen als bedoeld in artikel 7 , tweede lid, meent niet tot de afgifte van een verklaring van geen bezwaar tegen begraving of verbranding te kunnen overgaan, stelt hij de gemeentelijke lijkschouwer en de regionale toetsingscommissie bedoeld in artikel 3 van de Wet toetsing levensbeëindiging op verzoek en hulp bij zelfdoding, hiervan onverwijld in kennis.

$\mathrm{E}$

In artikel 81 , eerste onderdeel, wordt " 7 , eerste lid" vervangen door: 7 , eerste en tweede lid,.

Artikel 22

De Algemene wet bestuursrecht wordt als volgt gewijzigd.

In artikel $1: 6$ wordt aan het slot van onderdeel d de punt vervangen door een puntkomma en wordt een viifde onderdeel toegevoegd, luidende:

e. besluiten en handelingen ter uitvoering van de Wet toetsing levensbeëindiging op verzoek en hulp bij zelfdoding. 
HOOFDSTUK V.

SLOTBEPALINGEN

Artikel 23

Deze wet treedt in werking op een bij koninklijk besluit te bepalen tijdstip.

Artikel 24

Deze wet wordt aangehaald als: Wet toetsing levensbeëindiging op verzoek en hulp bij zelfdoding.

Lasten en bevelen dat deze in het Staatsblad zall worden geplaatst en de wet dat alle ministeries, autoriteiten, colleges en ambtenaren wie zulks aangaat, aan de nauwkeurige uitvoering de hand zullen houden.

Gegeven te "s-Gravenhage, 12 april 2001

Beatrix

De Minister van Justitie,

A. H. Korthals

De Minister van Volksgezondheid, Welzijn en Sport,

E. Borst-Eilers

Uitgegeven de zesentwintigste aprill 2001

De Minister van Justitie, A. H. Korthals 


\section{Summary}

In 1994 the Dutch government decided that physicians, who had assisted their patients to die and kept to the so called "requirements of due care', would not be prosecuted, though euthanasia and assisted suicide remained against the law. This drew criticism not only from abroad, but also in the Netherlands. A year after the law was passed a volume of essays was published titled Als de dood voor het leven. In this book a philosopher, a theologian, a psychiatrist, a jurist and a writer showed their disdain for the law. Each did so according to their profession: the philosopher examined the philosophical aspects of the legal toleration of euthanasia; the lawyer the legal aspects, and so on. There was one exception. A writer and poet, Willem Jan Otten, did not create a story or poem, but like his colleagues wrote an article. A reviewer deemed Otten's contribution to have literary qualities, because it examined the question of euthanasia and assisted suicide, in a non-rational, non-philosophical way. By doing so, the reviewer involved Otten in the age old debate between literature and philosophy, wherein literature is considered to be the domain of direct experience and feeling, and philosophy that of pure reasoning.

In the years before the publication of Als de dood voor het leven Otten himself had made a similar distinction between literature and philosophy. In 1994 his novel Ons mankeert niets was published. Ons mankeert niets is the story of a young doctor in a medium sized village in the province of Noord-Holland. With his story as opposed to an essay, Otten explained in several articles and interviews, he was better able to convey his objections to the legalization of euthanasia and assisted suicide. A purely rational, philosophical discussion, he thought, could not clearly explain why it is not permitted to kill someone, even upon their request. Not philosophy but literature, he said, shows the complexiry of reality and how much life and death are controlled by fate. Therefore, only literature can show why it is not permitted to kill a human being, even when 
incurably ill. Abstract reasoning would always discount that complexity. Furthermore Otten referred to the pre-Socratic tragedians, who made it clear to their public, without purely rational arguments, that human beings have no authority over life and death. He called Ons mankeert niets, "his own shot at a tragedy." His novel also demonstrated that death is a "non-human" matter. People who think they can control their own destiny, Otten wanted to explain in his novel, will be brought down.

Otten"s position that literature can help us with questions regarding ethics, and in the case of euthanasia and assisted suicide, with questions regarding medical-ethical problems, is not unique. Scores of books and articles have been published in the last decades which emphasize the importance of literature for ethics and for questions regarding the voluntary cessation of life.

In the meantime, law permitting the termination of life upon request and the assistance of suicide has become effective. Since April 12th 2001 physicians will no longer be prosecuted for having helped to end the life of a patient, or having given a patient the means to commit suicide, on the condition they have kept to the Requirements of Due Care. According to the law a physician who assisted a patient to die, is not punishable if he or she has been assured that the request of the patient was voluntary and carefully considered. The physician must also have been satisfied that the patient was suffering unbearably and that there was no prospect of improvement. The patient must have been informed about their situation and their prospects. The physician and the patient must have come to the conclusion, together with the patient, that there was no reasonable alternative in the light of the patient's situation. Furthermore, the physician must have consulted at least one other, independent physician, who must have seen the patient and given a written opinion of the due care criteria. The physician must have terminated the patient's life or provided assistance with suicide with due medical care and attention.

Otten has not changed his opinion regarding euthanasia and assisted suicide after the introduction of the law in 2001 . On the contrary, he continues to denounce the thought that people can sanction the killing of a fellow human being through abstract laws. He continues to resist the notions that we can talk in a purely rational way about euthanasia, that philosophical reasoning leads to knowledge and that we can regulate life and death.

Since the introduction of the law in 2001 more people seem to share Otten's criticism. Some critics point out that reality is more complex than the law presumes. We should not, therefore, follow the law indis- 
criminately. Furthermore, they call for a different debate of questions surrounding euthanasia, a debate different from a strictly rational one. In this debate there should be less emphasis placed upon abstractions and purely rational considerations, and a greater use of words and expressions of daily life. Also, physicians should be more attentive to the stories told to them by their patients and by others in novels, because in those the complexity of daily reality is expressed.

In the light of this criticism Otten"s novel could make an excellent contribution to the debate regarding law on euthanasia and assisted suicide. The question, however, is what does the novel show us? According to Otten literature shows us daily reality in all its complexity and peculiarity. At the same time he argues that literature makes it clear to us that humans are subjected to a universal, non-human authority: fate. Those who defy destiny by meddling with death - the "extra-human solution" as Otten calls it - will be destroyed. When we read the novel in the way Otten seems to wish us to do, we learn we are not subjected to human, but super-human laws, which prohibit us from killing each other, even if we are asked to do so by the patient.

But is that truly the only way to read the novel? Is that all the novel shows us? And is it this message the novel expresses: that daily life is subjected to a universal, extra-human law? If that truly is the case, the novel provides just one answer to the question posed on the jacket of the book: what do you do when someone wants to die? That answer is, in short: nothing. For most physicians caring for patients who wish to die, that answer will not be satisfying.

In order to answer these questions, we will have to return to philosophy, in spite of Otten's objections. However, a question above the rest, is whether we may make such a sharp division between philosophy and literature as Otten does. Since the nineteenth century many philosophers have devoted much attention to literature, because both philosophy and literature, they argue, are concerned with the knowledge of concrete reality. One of the exponents of that opinion is Maurice MerleauPonty (1908-1961). According to Merleau-Ponty the task of the writer is no different from that of the philosopher: both are focused on the experience of the world, as it originates before the thinking about the world.

Merleau-Ponty emphasizes that his philosophy is a method, which like literature expresses the pre-reflective experience. This thesis with the help of his "method" examines how we can read Ons mankeert niets in a different way than Otten seem to expect from us.

To get a clear picture of Otten's criticism of the legalization of euthanasia and assisted suicide, the first chapter of this study examines concerns 
that he has articulated in several essays and articles. As the requirements of due care are at the center of the debate as viewed by Otten and others the paragraphs of this first chapter are arranged according to these demands.

In the two following chapters Ons mankeert niets will be read in two different manners. The novel is written from the perspective of Justus Loef, a young physician who within two days of our meeting him will be confronted with several questions regarding euthanasia. Meanwhile, he receives several messages from and about his predecessor indicating he is planning to commit suicide. Justus tries to ignore these. On the second day he finds his predecessor dead in his house. Subsequently lustus flees to his boat in Friesland and writes an explanation about everything he has done and thought during the past two days. That explanation is the novel.

In the second chapter the novel is read according to Otten's idea of the tragedy. In this version the main characters of the novel are considered as victims of tragedy. They think that as rational human beings they have the license to dispose life and death, but in reality, everything they do is being guided by fate. The answer this reading gives to the question what to do when you know someone wants to die, is in fact: nothing. Those who interfere with murder, violate a taboo and will not avoid punishment. Thus the tragic reading offers a general answer to the question the novel poses.

Because Otten continues to emphasize that a novel in particular shows the direct, particular experience, in the third chapter a so called historical reading is presented. In this reading the banality and the peculiarities of the personalities are central. The question what you do when you know when someone wants to die can in this case hardly be answered, because it is too general for this reading. Everything that happens, is strictly dependent on the experience, the feelings and the plans of Justus, and you can only conclude that it would be to the benefit of his patients if he would be directed by more rational considerations and the general law. Because Otten emphasizes that his novel offers insight to the discussion of euthanasia and assisted suicide, both readings are structured by the Requirements of Due Care.

To lift the paradox between the particular and the general, and to provide insight to the connection between law and reality, the philosophy of Merleau-Ponty stands central in the fourth chapter. Merleau-Ponty shows us that our experiences are always particular as well as general. As body-subjects we are part of the concrete world, but we are capable of re- 
flecting upon our concrete experiences. As long as we realize and remember that the reflection is founded in the pre-reflective experience, we can profit by this reflection: without reflection there can be no medical and other natural sciences. Only, when we find the reflection more important than the experience on which it is founded, will it fail. We then consider, as Merleau-Ponty expresses, the map more important than the landscape and we make reality inferior to theory. We are trying then to capture reality in concepts and there exists the danger that people no longer see each other as fellow human beings, but as representatives of an abstract idea. Thus it could happen that incurably ill people, against their will, be killed by physicians, solely because euthanasia is not punishable by law. In that case the law determines, as Otten fears in his essay, reality. Those who use an abstraction of a law to control reality, act out of insincere motives.

But law and reality do not have to be at odds with each other. The stipullations of the law on euthanasia and assisted suicide can also be seen as expressions of concrete experience. If we together with Merleau-Ponty consider a novel not as the voice of an author, but as the reflection of "an inter-human happening," then Ons mankeert niets shows how the experience comes into being, and how the structure of our experiences are not necessarily perverted by a law, but can be expressed in it.

When we read Otten's novel from that point of view, the novel does not give an answer to the question what one should do when you know someone wants to die. Philosophy and literature do not give certainties, but are, like Merleau-Ponty says, works without conclusions. They reflect the structure of concrete experience and explain that the pre-reflective experience is the foundation of reflection. What Ons mankeert niets teaches us is therefore not unimportant. On the contrary: Otten's novel shows us that we always can and should act not out of insincere motives, when we know that someone wants to die. The novel reveals as does philosophy, that with ethical questions we cannot quickly reach certain answers, but we can and should adopt certain positions.

The final and concluding chapter five summarizes the previous chapters and further pursues the discussion of how physicians, in questions regarding euthanasia, can deal with law and reality, without one or the other domineering. In this chapter, Otten's essays and his novels and the philosophy of Merleau-Ponty are examined for the position we can take when we know that someone wants to die. 


\section{Dankwoord}

Werken aan een proefschrift naast een fulltime baan is niet altijd even praktisch. Het vraagt bovendien veel geduld van de omgeving van de promovendus en vooral van de promotores. Ik prijs mij zeer gelukkig met de begeleiding van prof. dr. Guy Widdershoven en prof. dr. Wiel Kusters. Beiden ben ik zeer veel dank verschuldigd voor hun adviezen en hun aandacht. De eerste heeft mij al tijdens mijn studie ingevoerd in de filosofie van Merleau-Ponty, en van hem komt het idee die filosofie toe te passen op een contemporain vraagstuk. Guy Widdershoven paart analytisch denken aan een grote belangstelling voor en inzicht in de literatuur. Wiel Kusters combineert eruditie met empathie, een zeer aangename eigenschap voor onzekere promovendi. Guy Widdershoven en Wiel. Kusters hebben mij de ware betekenis en de kracht van 'positieve kritiek" geleerd.

De familieleden die het meest geleden hebben onder mijn letterlijke en figuurlijke afwezigheid zijn mijn ouders Adriaan en Miep Soeting-Geusebroek, en mijn zussen Jeanne-Marie Soeting-Hellinger en Margreeth Soeting, die mij toch voortdurend gestimuleerd hebben. Van de vrienden die telkens weer gevraagd werden een afspraak te verschuiven en dat steeds zonder verwijten deden, noem ik Rob van Essen, Hanna de Heus, Linda Huijsmans, Kitty Jonk, Anneke Kaandorp, Anyke Kramer en Suzanne van de Vathorst. Liddie Austin hielp mij met mijn beide benen op de grond te blijven staan. Peter Romijn, Ed Tan en Berteke Waaldijk, die over grote doses optimisme, humor, empathie en doorzettingsvermogen beschikken, hebben mij tot voorbeeld gediend. De laatste in deze rij, maar allesbehalve de minst belangrijke, is Udo Nabitz, die te vaak met te weinig aandacht genoegen nemen moest.

Dank ook komt de volgende mensen toe: Nico van Velzen, die mij leerde door te zetten; prof. dr. William Hamrick, die mij net als Guy Widdershoven veel over de filosofie van Maurice Merleau-Ponty geleerd heeft en 
altijd bereid was naar mijn planmen te luisteren; prof. dr. Evert van Olst, die mij bij mijn eerste schreden op weg naar het proefschrift begeleidde; Frans Meulenberg voor zijn onovertroffen optimisme, bijstand, inspiratie en veelsoortige geschenken, en Ineke Schotanus en Leonoor Broeder voor hun onwankelbare solidariteit en hun meer dan praktische ondersteuning. Ik dank Hennie Voortman en Marjel Meeuwissen voor de mogelijkheid die zij mij boden Amsterdam te ontvluchten en in stilte en rust aan het proefschrift te werken; mevrouw Magda van der Grijn, medewerkster van de NVVE, voor haar hulp en haar gastvrijheid; Zeno en Cilia van Weerdenburg voor hun genereuze hulp bij de vormgeving van dit proefschrift en Theo Urllings en Rob van Essen voor hun nauwkeurige correcties. Mijn zus Jeanne-Marie dank ik voor de vertaling van de samenvatting, en Walter Hellinger voor zijn hulp daarbij.

Dit boek draag ik op aan twee vrienden, beiden veel te wroeg gestorven, blijvende inspiratiebronnen: Dieter Meyer en Hans Petri. 


\section{Curriculum vitae}

Monica Soeting (Amsterdam, 1955) volgde gymnasiaal onderwijs aan het Stedelijk Gymnasium te Leeuwarden en het Dr. Nassau College in Assen. In 1973 haalde zij het highschool diploma aan de Kamehameha Highschools in Honolulu, Hawaii, en in 1975 deed zij staatsexamen gymnasium alfa te Den Haag.

Nadat zij een jaar lang gewerkt had in Zuid-Duitsland en Zwitserland, begon zij in 1977 met de studie filosofie aan de Eberhard-Karls Universität in Tübingen, Duitsland. In 1979 legde zij de Zwischenprüfung met goed gevolg af. Van 1979 tot 1981 studeerde ze filosofie en psychologie aan de Universiteit van Amsterdam. Deze jaren sloot ze af met het kandidaatsexamen. Zij studeerde enkele jaren kunstgeschiedenis in Tübingen, die ze met de Zwischenprüfung afsloot, en haalde in 1988 haar doctoraal examen wijsbegeerte aan de Universiteit van Amsterdam.

Monica Soeting werkte van 1990 tot 1992 als medewerker buitenland bij de Nationale Woningraad. Tot 1999 was zij hoofdredacteur van het tijdschrift Surplus. Daarna was zij als recensent verbonden aan Vrij Nederland, Trouw, Surplus, Biografie Bulletin en de Volkskrant en maakte zij deel uit van de redactie van de Gids. In $2002 \mathrm{kreeg}$ zij een aanstelling als redacteur bij uitgeverij Atlas in Amsterdam. Tegenwoordig werkt zij als redacteur bij uitgeverij Ambo|Anthos. Monica Soeting is hoofdredacteur van Biografie Bulletin, levert bijdragen voor de literatururbijlage van Trouw en het Duitse recensieblad Virginia, en is betrokken bij het project. "Learning through Fiction" dat uitgevoerd wordt door de vakgroep medische ethiek \& filosofie van de geneeskunde aan de Erasmus Universiteit Rotterdam. 